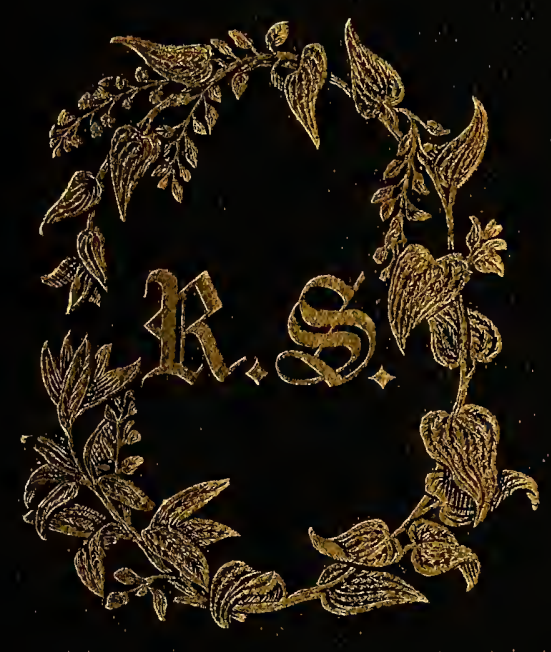




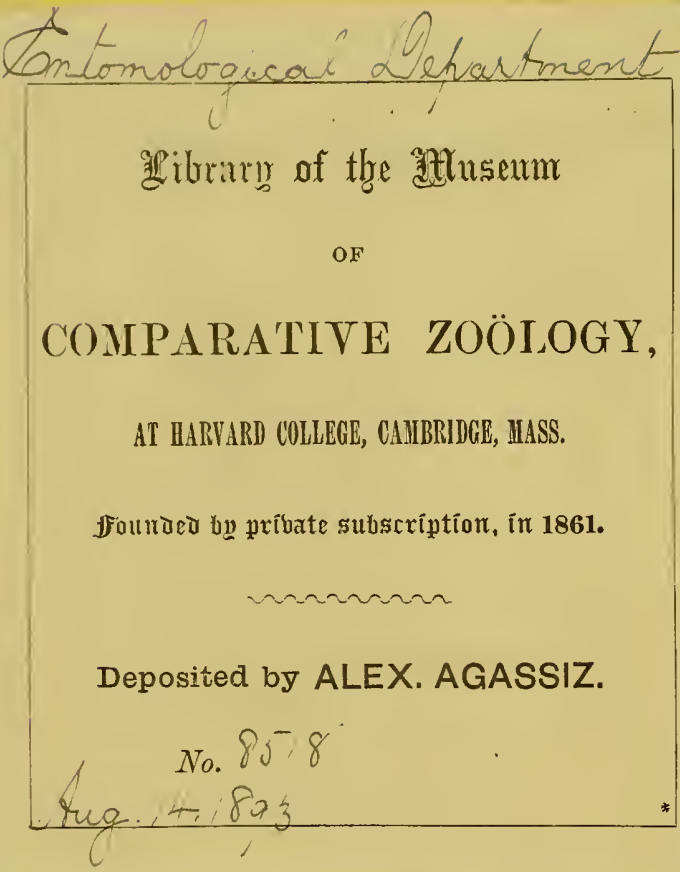


PECT

AUG ? 1 Inan 



\section{THE}

\section{R A Y SOC I E T Y. 70}

INSTITUTED MDCCCXLIV.

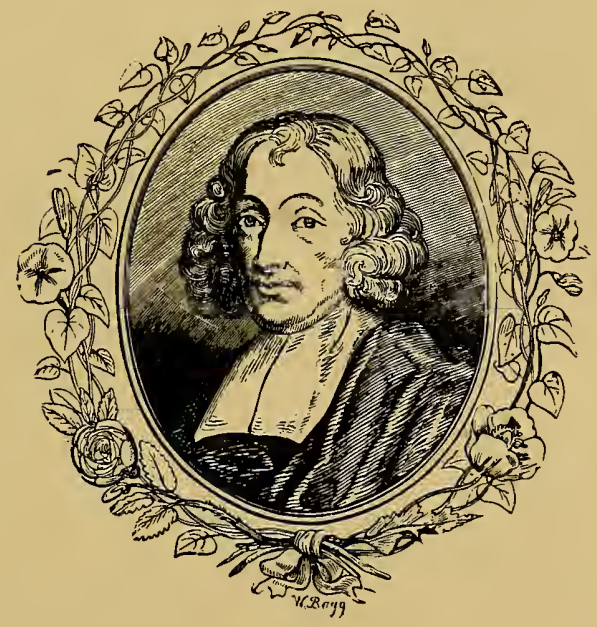

This volume is issued to the Subscribers to the RAY Socnuty for the Year 1892.

\section{O N D O N :}

MDCCCXCIII. 



\title{
A MONOGRAPH
}

OF THE

\section{BRITISH}

\section{PHYTOPHAGOUS HYMENOPTERA.}

(CYNIPID正 AND APPENDIX.)

\author{
VOL. IV.
}

$B Y$

P E T E R C A M ER ON.

LONDON :

PRINTED FOR THE RAY SOCIETY. 


\section{MCZ LIBRARY HARVARD UNIVERSITY \\ CAMBRIDGE. MA USA}




\section{PREFACE.}

THe present volume concludes this work. In the four volumes are described 382 species of Tenthredinidæ, 9 of Cephidæ, 5 of Siricidæ, one of Oryssidæ, and 179 of Cynipidæ, in all 576 species.

The Appendix brings up our information to date, more particularly as regards the nomenclature and biology of the groups. As will be seen, considerable alteration has been made in the definitions of the genera, their number, as compared with what Thomson and myself have adopted, being greatly increased. The only remark I make on this subject is that if exotic species are to be treated according to the same method a large number of genera or sub-genera will have to be created.

The Bibliography I have endeavoured to make as complete as possible; but, owing to the difficulty of getting access to many foreign magazines and Transactions of Societies, I have no doubt that many papers have been omitted.

In conclusion I have to thank my correspondents for their valuable assistance; and more particularly as regards this volume I have to thank Prof. G. L. Mayr, Prof. J. W. H. Trail, the Rev. T. A. Marshall, M.A., Mr. G. C. Bignell, Mr. J. E. Fletcher, and Dr. J. T. Oudemans for much help.

Sale, Cheshire;

March, 1893. 



\section{A MONOGRAPH}

OF THE

BRITISH

PHYTOPHAGOUS HYMENOPTERA.

VOL. IV.

\section{CYNIPID王.}

\section{Tribe CYNIPINA.}

(The taxonomic characters of this tribe have been detailed in vol. iii, p. 157.)

\section{The Egg.}

The egg is elongated, rounded at the top, becoming gradually narrower until it terminates in a long peduncle, which may be hardly longer than the egg itself, or seven or eight times longer than it. This peduncle is not peculiar to the eggs of the Cynipidæ, it being found to exist in certain groups of Ichneumonidæ (e.g. Tryphon) and Chalcididæ (e.g. Leucaspis); but in the Cynipidæ, according to Adler,* it differs in this respect from the others, that with them the peduncle is at the anterior, in Tryphon, \&c., at the posterior pole of the egg. The use of the peduncle is somerwhat

* Zeits. f. wissen. Zool., xxxv, 223.

VOL. $1 \mathrm{~V}$. 
problematical, but Adler's suggestion that it is respiratory appears to be founded on some solid grounds: e.g. those species which have very long peduncles are those which place the eggs in positions where they cannot receive oxygen from the plant-the spring generations, which have their eggs placed in the leaves where they can get oxygen from them, have it short; while the winter generations, as a rule, have it long. The peduncle is always placed uppermost.

The number of eggs laid is frequently very great. It is certain that the ovaries of some species can contain about 600 to $700 \mathrm{eggs}$; but as many as 1400 flies have been reared from a gall of Andricus radicis. In this case, however, it is certain that this gall was the conjoint work of two or more individuals. The labour of oviposition with the sexual broods which lay in leaves is comparatively easy; but in other cases the work is long and laborious. Thus Biorhiza aptera takes over three days to complete its egg-laying. It has first to pierce the bud with its ovipositor to make tunnels in which to introduce the eggs to the centre of the bud, where they form a solid mass.

A noteworthy feature in the eggs of the Cynipidx is their swelling, which takes place after being introduced into the plant.

\section{The Larva.}

The larva is footless, white and fleshy, has thirteen segments, and possesses little power of locomotion, as might be expected, except with some species-e.g. Andricus saliens, which can make the galls jump. As may be surmised, the duration of the larval life varies with the spring and winter broods; while a month is sufficient for Spathegaster baccarum, two or three years are necessary for others. In other words, while one year is sufficient to complete the cycle of life for some species, Andricus radicis requires two, this 
extra length of time being taken up with the agamic winter form. The development of this gall is not continuous ; for in October, or month following the laying of the eggs, a slight growth takes place, followed by a cessation of development during the winter, owing to the inactive growth of the plant, to be resumed in the spring. A curious point is that in many winter forms cases are met with wherein the larvæ remain unchanged for several years. I believe this is frequently the case with Andricus gemmæ and A. glandium. How far this is owing to atmospheric influences or to more subtle causes it is difficult to say.

\section{The Pupa}

is, like the larva, white and fleshy. It has the antennæ placed along the breast, the legs alongside of them enveloped in pellicles, and the wings appear as bag-like protuberances on the sides of the thorax.

\section{The Imago.}

Apart from their peculiarities of oviposition, which offer interesting features, the flies do not show many points of interest. They are exceedingly sluggish, seldom flying any distance. So far as we know they take no food, and do not frequent flowers like so many of the parasitic Cynipidæ. They do, however, imbibe water, as may be often witnessed. Many of them have a habit, when alarmed, of tucking the appendages close to the body and dropping motionless to the ground.

A noteworthy point is that some of the species, e.g. Biorhiza aptera, appear in the dead of winter during snow and frost, and even with the atmosphere at freezing point proceed to lay their eggs.

The males differ from the females in having the antennæ longer and thinner, and in having one or two joints more; there is no difference in coloration, 
but they are smaller, and the abdomen especially is shorter and differently shaped. The sexual forms are more active and fly about more than do the agamic.

From the sexual females the agamic differ frequently in many particulars. Generally they are larger and more bulky in shape; there is often a difference in coloration; the autumn form may be wingless, the spring winged, or, as in $B$. terminalis, the spring brood may sometimes be wingless as well as the autumnal. The agamic generation, again, live longer than the other. Sometimes there is a difference in the palpi, as in the autumn form of Biorhiza megaptera having four joints in the maxillary and two in the labial, while the spring brood has one joint more in both. More remarkable still, there may be a difference in the oral apparatus in the larvæ.

The difference in the form of the ovipositor is very marked -a difference not only in size, but in form: in the spring generation it may be short, with the boring apparatus straight and not much longer or even shorter than the ovipositor itself; while in the other brood it may be much larger and longer, with the borer curved round it.

As a whole the gall-making Cynipidæ are larger than the parasitic. Black is a prominent colour for their bodies, but many are brown, fulvous, or yellow, and a few reddish.

The specific distinctions are often very obscure; indeed, in not a few instances the flies cannot be separated at all; e.g. Andricus albopunctatus, A. callidoma, A. Malpighi, A. 4-lineatus, \&c., and many species of Cynips. In those cases the only trustworthy criterion of specific distinctness is furnished by the galls. Colour may occasionally afford a good character - e.g. Trigonaspis megaptera, but in others it is quite worthless. The structure and number of joints in the antennæ, the form of the wing-cells, the sculpture of the thorax, and to a certain extent the clothing of the body, the length of the parapsidal furrows, and the 
form of the head behind the eyes give the best specific characters.

The Cynipina are chiefly known from the Palæarctic and Nearctic zoological regions. Very probably they are found wherever oaks and roses abound. They are abundant in the United States of America, are known from Mexico (Cynips, Aulax, Synergus), and from Northern India. One genus (Eschatocerus, Mayr) is recorded from the Banda Oriental, where it forms galls on acacia. The genus Rhodophilus, Mayr, comes from the Cape of Good Hope, galling Rhus lucidum. A few species are common to Europe and America, e.g. Rhodites rosæ, Aulax glechomæ.

Cynips is practically absent from the northern parts of Europe, but is prevalent in the centre and south of Europe. It is rare in the United States.

\section{Parthenogenesis and Alternation of Generation}

Until the time of Hartig the many anomalous features in connection with the natural history of the gall insects received but scant if any attention. Hartig in $1843^{*}$ became aware of the fact that certain species appeared to have no males, and in the course of his experiments. bred no less than 9-10,000 examples of Dryophanta foli out of 28,000 galls, every one being a female. Hartig surmised, from his anatomical examination of the insects, that they were hermaphrodite; but his observations on this point were speedily disproved by von Siebold. $\uparrow$

A survey of the subject at that time led to the generalisation that those species which appear in spring or early summer were bisexual, while those whose galls appeared in the autumn were without exception agamic. On the supposition that this was so, it followed that the spring gall-flies must lay eggs

* Germ. Zeit., iii, 398.

† L. c., iv, 362-388. 
which remain (on the assumption that they were not dimorphic) dormant till the following spring. In the case of a species like $D$. foli, whose larval, pupal, and imaginal existence is short, it followed that the egg must remain undeveloped in the bud. The species of the restricted genus Cynips stand on a different footing, for we now undoubtedly know that they are without exception unisexual ; but we are also aware that it is the larva, not the egg, which remains dormant.

The subject remained in this state for many years until 1861, when Baron Osten Sacken (Stett. Ent. Zeit., 1861) emitted the view that the males did exist, but that they lived in separate galls-an opinion on which there was no proof available. Three years later the well-known American naturalist, B. D. Walsh, produced evidence to show that Cynips spongifex, O. S., caused a large round swelling on the leaves of Quercus tinctoria, and that the insect issuing from this gave origin to another gall, known as Cynips aciculata - the one appearing in the spring in a bisexual form, the other in the autumn being agamic. Walsh looked upon this as a case of dimorphism.

Bassett, another American entomologist, placed the matter on a clearer footing by showing how some bisexual spring forms, living in a distinct gall, gave origin to a unisexual brood living in a differently constructed gall in the autumn.

Riley, the American State Entomologist, also elucidated the subject by showing that $C$. operator, O. S., which comes out of a "large woolly gall, the deformation of a bud which grows on our black oaks in spring, produces in summer a common gall-fly (C. q. operator, O. S.), which is bisexual. The female oviposits between the acorn and cupule of the previous year's setting, aud the result is a pip-like gall (C. operatola, Rly) embedded in that position, and generally half exposed. These fall with the acorn to the ground, and the second spring generation suc- 
ceeding give forth flies which are all female, and which produce the woolly galls of spring" (Johnson's Cyclopædia, p. 422). From this and other observations Riley deduces the fact that there can be little doubt that "all species known only in the female sex exist also in the bisexual form, though the gall producing this last may present an entirely different appearance from that producing the former" (l.c.). That, however, is too trenchant a surmise, for in Europe at least we know species only existing in the female sex.

But it was not until the classic researches of Adler appeared that the natural history of the Cynipidæ was thoroughly elucidated. By a series of careful and long-continued elaborate studies he proved that, at least so far as the North European species were concerned, there is no one species with two sexes but has an autumnal agamic form-that there was an alternation of a bisexual with a unisexual form-that here we had a case of alternation of generations, and not of dimorphism, as was surmised by Walsh.

How are we to explain the occurrence of this remarkable phenomenon? We find (1) species (but not on the oak) with only one generation, and haviug males and females; (2) species on oak with one generation and no male; and (3) species with two generations, the one sexual, the other (autumnal and winter) agamic. In the first division there is undeniable evidence of parthenogenesis ; and, further, as the case of Rhodites rosce testifies, it is clear that the males have disappeared as the faculty of virgin reproduction increased. From this fact, and from the considerations given in vol. i, p. 29, and ii, p. 218, we may fairly assume that those of the second section had at one time males. So far, therefore, as these two groups are concerned, there is nothing unusual, since we find the same phenomenon in the Tenthredinidæ and in other insects; but in the third division we have a state of matters much more unusual and complex, and conse- 
quently more difficult of explanation. Indeed, at present no adequate elucidation of the origin of the phenomenon has been given.

Had the agamic generation at one time a $\delta$ ? On this point Adler makes the following highly interesting observations. Alluding to the manner of coition, he says, "In repose, with those flies which have a long ovipositor the entire boring apparatus is retained inside the abdomen; if fecundation took place with it in this position it would be necessary that the penis of the $\delta^{\pi}$ was equal in length to the ovipositor rolled in a spiral. But it is infinitely shorter; further, it is only when the ovipositor is extended that the vagina becomes accessible to the $\delta$. Now, as the agamic generations have preserved the habit of extending their organs, does not that indicate that they had at one time males?" (Zeit. f. wiss. Zool., xxxv, p. 236). Again, did the second form originate from the present agamic or bisexual form? Both lay eggs; and although we have no direct observation on the point, it may be fairly surmised that the only difference between them, as between other sexual and parthenogenetic eggs, is that the former extrudes both and the latter only one of the "polar bodies." The first "polar body" is extruded from all eggs, and in the fertilised eggs the second is replaced by the male sperm.

Following out his ideas on cyclical generation in the Aphidæ, or, as he calls them, the "homoptères monoïques," Lichtenstein regards the agamic form as a larval stage equivalent to the migratory form of, e.g., Phylloxera.

In his Considérations nouvelles sur la Génération des Pucerons, p. 13, Lichtenstein defines for the Aphidx four forms, as follows :

The first-the "Souche monoique"-terminates in a large insect, living a long time, always readily recognisable by its size, especially with the gallicolous species. 
The second-the "Émigrants" - only live the time necessary to transplant their buds to other plants.

The third-the "Bourgeonnants" - reproduce without limit so long as they have the necessary food, heat, and moisture.

And the fourth-the "Pupifères"-carry in the womb the sexual pupæ (or at least the separate sexes) which should copulate and furnish the fertile eggs.

Lichtenstein regards the agamic Cynips as a larval stage equivalent to the migratory form of the Aphis.

The gist of this theory is that a single egg gives, after a series more or less long of various forms, sexual individuals, male and female; and further, with the same insects, the winged form, which appears twice in the cycle of their existence, is no other than a larval form of transition, and is not sexual in at least one of its forms. Under this view he arranges the Cynips cycle thus :

1. Eufs de la femelle fécondée et larve en provenant dans la galle dure d'automne. Les fondateurs (Pseudogyna fundatrix).

2. Ailés émigrants sans sexe, tous identiques, avec une longue tarière en spirale et allant piquer les bourgeons (Neuroterus lenticularis).

Les émigrants (P. migrans).

3. Eufs-bourgeons et larves en provenant, qui s'entourent d'une galle charnue en forme de groseille.

Les bourgeonnants ( $P$. gemmans).

4. Les insectes sexués (Spathegaster baccarum, L.), mâles et femelles.

Les sexués (Sexuata).

I can hardly agree to this larval view of the agamic form, more particularly when we find their ovaries and eggs normal, their modes of oviposition identical; when, in fact, we can explain the phenomenon by the theory of parthenogenesis - that, in brief, we have here no case of budding. Again, as above pointed out, we have strong reasons for believing that at one time the agamic females had males.

Our agamic species, or at least those at present known in only one sex, are-

Cynips Kollari.

Andricus 4-lineatus. 


\section{Andricus marginalis. \\ - albopunctatus. \\ - seminationis. \\ - solitarius. \\ - glandula. \\ - Clementinoe. .}

Dryophanta agama.

disticha.

The first five are certainly agamic, but at present we have no definite information about the others. Andricus amenti (a spring bisexual form) is sure to have an autumn agamic form. The galled acorns I have found seem to point to an unknown species.

\section{Parasites and Inquiline or Guest Flies.}

The insects which live at the expense of the galls, or gall insects, are exceedingly numerous. They are of three classes :-First, inquilines; second, parasites ; and thirdly, commensals. The inquilines are species of Synergus, Ceroptres, or Sapholytus, all forms nearly related to the true gall makers. They do not make galls themselves, but deposit their eggs in galls already formed; live in the gall substance; and, as a rule, kill the larva of the maker. The parasites are chiefly Chalcididæ, small brilliant blue or green metallic Hymenoptera, which devour the larvæ and pupæ of the gall or inquiline flies. The most conspicuous of these parasitic genera are Callimome and Torymus, which have a more or less elongated ovipositor to enable them the better to penetrate into the galls, the ovipositor with some of them being three times longer than the body ; Eupelmus, Orymus, Megastigmus, Eurytoma. These Chalcididæ may confine their attacks to one gall or to many, e.g. Eupelmus annulata, E. Degeeri, Eurytoma vagabunda, and species of Olinx. So far as my observations go these are all external feeders, and feed on the pupa as well as on the 
larva: Chapman (Ent. M. M., ix, 13) records a Chalcid feeding on the imago of Biorhiza aptera. The eggs are not always laid in the body of the victim.

The third class-the commensals-are mostly found in the large galls, such as those of Andricus terminalis, and feed on the gall mass without, as a rule, interfering with the development of the host. Cetonia, Balaninus, and various moths devour the tissue. As an example of the manner in which the terminalis galls afford lodging and food to insects, it may be here recorded that the late Francis Walker (Zool., 1846, p. 1454) reared the following from a mass of terminalis galls; namely, Coleoptera, 9 species, 191 specimens; Orthoptera, 1 species, 5 specimens ; Neuroptera (Psocus), 2 species, hundreds of examples ; Cynipidx, 4 or 5 species, 30,246 specimens; parasitic Hymenoptera, 45 species, 24,417 specimens; Diptera, 3 species, 23 specimens; Lepidoptera, 5 species, 9 examples; Hemiptera, 5 species, 51 specimens; Arachnidæ and Acari, 5 or 6 specimens. Total, 75 species, 55,000 specimens and upwards.

The chief works, from the biological point of view, on the parasites of gall-flies are-

Ratzeburg. Forstinsecten.

Mayr. Die Europäischen Torymiden (Ver. z.-b. Ges. Wien, xxiv, 1874; Die Chalcidier-Gattung Olinx (l. c., xxvii); Die Arten Chalcidier-Gattung Eurytoma (l. c., xxviii).

Giraud. Liste des éclosions d'Insectes observées par le Dr. Joseph Étienne Giraud, recueillie et annotée par M. le Dr. Alexander Laboulbène (Ann. Soc. Ent. Fr., 1877, 397).

Kirchner. Catalogus Hymenopterorum Europæ.

Kaltenbach. Die Pflanzen-feinde.

The purely descriptive works are those of-

Waller. In the Entomological Magazine and in his Monographia Chalciditum (1839).

Haliday. In the Entomological Magazine. 
Foerster. Hymenopterologische Studien, ii; his Beitr. zur Monographie der Pteromalinen, 1841.

Nees ab Esenbeck. Hymen. Ichneumon. affin. Monogr., vol. ii (1834).

Thomson. Hymen. Scan., iv and v.

Thanks to the admirable monographs of Mayr on the Torymina, Olinx, and Eurytoma, the identification of these groups is rendered comparatively simple; but some of the others, and more particularly Pteromalina and Tetrastichus, are in the utmost confusion. The number of Ichneumonidæ and Braconidæ parasitic on the Cynipidæ is comparatively small.

\section{Galls.}

All the galls of the Cynipidæ are completely closed, none of them being open as we find them in Hemiptera and some Diptera. As regards texture and consistence they may be divided into the soft and succulent, and the hard and woody; as regards position on the plant they fall into two groups : first, those which are entirely external from the plant, being only attached to it by a small part, e.g. Rhodites eglanterix; and secondly, those which are more or less embedded in the plant tissue, e.g. Rhodites spinosissima. Again the galls may have many cells (polythalamous), or have one only (monothalamous); but the latter, by the influence of inquilines, may be made polythalamous.

\section{Forms and Origin of Galls.}

The forms of galls are endless. They may be round, spherical, lenticular, oval, or perfectly flat. They may be permanently attached to the tree (Cynips Kollari), or, when ripe and the larva at maturity, may drop immediately to the ground from the leaf or bud, or may drop before the larva is fully developed, the 
gall remaining inert until the early spring, when growth sets in. In texture we find equal variety. They may be perfectly smooth, or rough and reticulated. From the perfectly glabrous galls of Neuroterus baccarum there is every transition, from the shortly-haired galls of Neuroterus lenticularis to the galls of Andricus ramuli, which are enveloped in enormously long hair. A few galls exude a glutinous secretion (Andricus Sieboldi, A. glutinosus). In Rhodites we have galls with four or five stout spines, and others where the gall is thickly spined all over. In herbaceous plants the galls usually take the form of strumous swellings, as also in Rubus.

The colour of the galls is, as a rule, at first with many, e.g. Andricus radicis, Cynips Kollari, white, or white with pink, the latter apparently being developed by sunlight, and is probably altered chlorophyll. The catkin galls are greenish, getting brownish with age. Other galls remain always green.

Every part of the plant is attacked by the gall-flies. The roots, the trunk, the leaf, either on its surface, edge, or veins and midrib, the $\delta$ and $q$ flowers, and the fruit are all utilised. As a rule each form confines its attack to one particular part of the plant, but there are exceptions to this. Thus the gall of Neuroterus baccarum (spring form) is found on the leaves and on the $\delta$ catkin, Andricus radicis on the roots and on the trunk. We know also of cases where different plants are used. At least two European species are polyphagous. Biorhiza aptera has been found at roots of beech (Curtis), firs (Masters), vine (Magretti), and Diastrophus rubi has been recorded as having been found on the galled tops of Pteris aquilina. Aulax hieracii, besides attacking various species of Hieracium, occurs on Cistus and on Triticum. Apart from the case of B. aptera, no species of Cynips, Andricus, Dryophanta, Biorhiza, and Neuroterus are found on plants other than the oak. 
How are we to account for the various forms, colour, and texture of galls? I believe largely to the action of natural selection in developing them, so that their forms, texture, clothing, and colour may afford protection, directly or indirectly, to the tenants. These means of defence may be classified as follows.

First, Size.-Bearing in mind that the larva inhabits the centre of the gall only where it occupies a cell of its own size, surrounded by a thickened wall, it is obvious that the greater the distance between the centre and the external layer, the better it is protected from the attacks of its enemies. Hence largeness of size is a powerful aid to the larva : first, from the attacks of Chalcididce and ichnemunos, very few of which have sufficiently long ovipositors to reach the centre of a gall like Cynips hungarica; and second, from the inquilines (Synergi), which can live in the galls without disturbing the legitimate tenant. I have several times reared Synergi and the Cynips from C. Kollari galls; the inquiline in these instances being in a cell near the edge of the gall, as shown in Pl. II, fig. 6, a. Further, those large galls are made chiefly by species of the genus Cynips, which is a unisexual genus; the larva, pupa, or imago remaining in them during the greater port of the year, and hence are liable to attacks for a long period. The space between the larval chamber and the circumference, at first spongy or fungoid-like in texture, becomes with age converted into a mass of powdery substance, which is certainly highly astringent from the presence of tannic acid. Inexperienced birds, we know, peck into the galls for the larva; and in doing so get this bitter dust into their mouths-not, it may be imagined, to their relish; while, again, the larvæ themselves contain some noxious compound. One of the best examples of this class is the well-known "Dead Sea apples" (Cynips insana),-

"Which tempt the eye,

But turn to ashes on the lips." 
Nor must the hard and woody nature of these large galls be omitted from mention as a means of defence, for obviously they can be attacked by insects only during the short period they are soft.

Conversely, the small size of the gall is a protection-first, by hiding it, making it less easily seen by parasites; and secondly, by its small size offering sustenance to only one inquiline-e.g. Andricus nudus, albipes, pilosus.

Second, Colour.-Colour as a protection is best seen in the small catkin galls. At first green, like the young catkins, they with age become brownish, like the old catkins; and this resemblance is, in some of them, further increased by their being pilose, e.g. Andricus amenti.

Third, Smell.-This phenomenon is doubtless accompanied by some noxious principles which make the larvæ unpalatable to birds, \&c.; and is, as mentioned above, found chiefly in the larger species which inhabit large galls all the year round. Both the larva and imago may give out an offensive odour. Cynips Kollari and Dryophanta foli are cases in point. The smell given out is usually bug-like, but Paszlavszky (Wien. Ent. Zeit., 1883, 130) mentions that foli has the smell of ripe apples; $A$. radicis of lemon; $A$. Sieboldi and Cynips tinctoria of caramel, or fresh malt, with a trace of bug-smell. According to the same authority, the foli individuals bred from the sessile oak have the smell much more intense than those from the pedunculated.

Of the Bedeguar gall-flies, Réaumur says (Mémoir, iii, p. 494) that they have a quality which he had not met with in other gall-flies, namely, that they have a smell which is attractive to cats.

Fourth, Clothing and Texture.-The long hairs sulrounding the galls of many species, often (especially when young) more or less glutinous, afford protection to the larvæ. In other species the surface exudes a glutinous secretion. 
Cynips glutinosa is a well-known example of this. Giraud (Verh. z.-b. Ges. Wien, 1859, p. 342) relates that this exudation glues small insects to the gall, and this observation is confirmed by Paszlavszky,* who has found Hemiteles (an ichneumon), Torymids, and other gall parasites so attached. In our own country we have an even more interesting case in Andricus Sieboldi, whose galls give out a secretion which, as was first pointed out by Dr. Adler, $\dagger$ is much relished by ants, which, as stated by the same author, cover them with sand and earth, so as not to be canght themselves when getting the liquid. I have myself noticed the ants at the gall secretion, but the galls were not covered. The spines on galls, as in the American Rhodites bicolor, must also be a protection. From observation, and from a study of the published notes in the rearing of parasites and inquilines, it seems to me clear that the smooth galls have a larger number of parasites than the hairy, rough, or glutinous ones.

As another means of protection may be mentioned the short duration of some galls on the tree, e.g. Andricus aprilinus; the falling to the ground when ripe of many bud-galls, where they are lost among the herbage, \&c., to which their colour assimilates, being at first green, then becoming brownish; the dropping to the earth of Neuroterus lenticularis before it is fully grown or the larva mature, thus reducing the period during which it can be attacked by parasites. So, too, the larva chamber in Andricus curvator being loose, and surrounded by a large empty space, may protect it.

The springing habit of some gall larvæ may also do so. This fact was first alluded to by Olivier (Hist Ins., ii, p. 318); then a fuller description of the jumping habits of Andricus saliens was given by Kollar, Verh. z.-b. Ges. Wien, 1857, p. 513, and by Giraud, l. c., 1859 , p. 352 . According to the latter, they can

* Wiener Ent. Zeit., ii, p. 131.

† Zeit. f. wissen. Zool., xxxv, p. 172. 
leap from one to two inches; and when a number are confined in a box, the noise they make by falling on the leaves is like the rain falling on a window. Riley* describes the jumping galls of Andricus saltatorius as presenting a curious spectacle from their keeping up a constant jumping or bouncing movement on the ground. It is obvious that the movement is effected by the larva bringing the head in contact with the anus, thus forming an empty space at either end of the gall; and when the ends are brought into them again, the gall is set in motion by the sudden expansion of the larva.

It is well understood that the forms, colours, \&c., of external feeding caterpillars (see vol. i, p. 46, et seq., for information on this point as regards saw-fly larvæ) have been evolved by natural selection for their protection from insects and other enemies. Obviously, as regards the hidden gall larva, its form and texture could not be affected in the same manner. But it is clear that the gall stands in the same relationship to the larva as its skin does to the external feeding caterpillar. The gall larva itself, being hidden, did not afford means for natural selection to act upon; but the gall did; and hence we see developed, for the protection of the larva, the various contrivances I have just enumerated.

But while, to my mind, we can explain, as I have described, the forms of galls, it is not so easy to explain the origin of the galls as galls, without reference to their forms and structures.

The theories promulgated by the early naturalists, on the origin of galls have practically no scientific value. Some attributed their origin to spontaneous generation. One author concluded that the eggs were drawn up with the sap from the ground to the leaves, \&c., on which they were found. Redi, $†$ who had himself successfully exploded the theory of spontaneous generation, had an equally absurd method of accounting for

* Johnson's Cyclopædia, p. 423.

$\uparrow$ Experienze intorno alla Generazione d' Insetti, 1668.

VOL. IV. 
galls. He assumed that the plant had a vegetable soul, this vegetable soul presiding at the origin of galls, with their eggs, larvæ, and imagos; while it, again, gave issue to fruits. Linné explained the matter by asserting that the galls were formed by the outflow of sap from the wounded parts.

Malpighi (Opera Omnia, De Gallis, 1679) may be said to be the first scientific observer of galls. Indeed, considering the time in which he lived, his descriptions and figures of galls are wonderfully accurate-much more so than those of Réaumur. Malpighi noticed a fly oviposit in the leaf. He observed that a liquid exuded, and from this he concluded that the galls were caused by a process of fermentation; the liquid inserted acting as a ferment on a supposed "vitriolic acid" which existed in the plant.

Réaumur (Mémoirs, vol. iii) advocated a theory of mechanical irritation by the ovipositor, the egg (for Réaumur was aware that the egg increased in size after being deposited in the plant) larva, and also to a supposed increase of temperature in the egg. $\mathrm{He}^{*}$ compared the egg with its supposed higher temperature contrasted with the plant to a small furnace giving heat to all the surrounding fibres, this heat assisting in their growth. The French naturalist, in his examination of the ovipositor, found that it varied in form in different species. This diversity of form would act differently when inserted in the plant, and hence would lead to differently shaped galls being formed. As regards the structure and consistence of the galls, he states that it was easy to account for them by each species absorbing during its development different juices. Thus spongy galls, like Andricus terminalis, absorbed juices which developed spongy structures; woody galls, which gave origin to hard and woody formations, from woody structures.

Lacaze-Duthiers (Annales des Sciences naturelles, Botanique, xix, 31) advocates what may be called * Mémoirs, iii, p. 504 . 
the infection theory. Just as the germ of smallpox inserted into a human subject gives issue to smallpox and not scarlet fever-as each infectious disease had its origin in its own specific germ,-so it was assumed that each gall-fly was provided with a specific poison peculiar to itself, which produced its own specific gall-structure.

Until recent years this theory was the one which was held in most general repute. Darwin, apparently on the strength of Lacaze-Duthiers' memoir, accepted it without question. 'L'hus (Animals and Plants under Domest., ii, p. 384) he says, "As the poisonous secretion of insects belonging to various orders has the special power of affecting the growth of various plants ; as a slight difference in the nature of the poison suffices to produce widely different results ; and, lastly, as we know that the chemical compounds secreted by plants are eminently liable to be modified by changed conditions of life, we may believe it possible that various parts of a plant might be modified through the agency of its own altered conditions". Again, he says, "When we see the symmetricaland complex ou torow ths caused by a minute atom of the poison of a gall insect, we may believe that slight changes in the chemical nature of the sap or blood would lead to extraordinary modifications of structure" (Origin of Species, (p. 572). In the same work (p. 9) he says further, "as the complex and extraordinary outgrowths which invariably follow from the insertion of a minute drop of poison by a gall-producing insect show us what singular modifications result, in the case of plants, from a chemical change in the nature of sap."

Prof. Riley accepts also this view. In the article "Gall Insects," in Johnson's Cyclopædia, p. 422, he says, "With the ovipositor . . . the female pierces the plant tissues, and therein consigns an egg, together with a small quantity of a peculiar poisonous fluid. Under the influence of this fluid the gall rapidly develops, and is generally fully formed before the egg 
hatches;" but this latter remark does not hold with the Cynipidæ, as has been shown already.

Sir James Paget likewise supports the infection theory. Thus he says, "In these and other similar diseases in plants we have, it seems, hundreds of specific diseases due to as many hundreds of specific morbid poisons; for the most reasonable, if not the only reasonable theory of these diseases is, that each insect infects or inoculates the leaf or other structure of the chosen plant with a poison peculiar to itself. The poison may be merely deposited; but in the instances best for study it is inserted in the plant structure, whether leaf or any other: and the wound for inserting it, the poisoned wound, may be made either with part of the oral apparatus, or, as in most of the true galls, with the ovipositor, through which one or more eggs are passed with the virus, and are left among actively living structures of the plant. The little wound closes; the virus, whether an oral or an ovarian secretion, remains; and the result of its influence on the plant structures and their contained protoplasm is the formation of the gall or other morbid product." Further on he says, "We find hundreds of different forms of galls, and we may be nearly sure that there are as many kinds of morbid poisons produced by gall insects, each form answering to a different insect" (An Address on Elementary Pathology, London, 1880).

Now in considering this question it must be borne in mind that very many insects, of divers orders and modes of life, cause the formation of galls. Hymenoptera as represented by Cynipidæ, Tenthredinidæ, and Chalcididæ. The order of Diptera furnishes many exponents; some beetles; the Hemiptera, especially the plant lice, all form galls. Further, a large number of galls are caused by minute four-footed mites (Phytoptus); and, again, some are formed by Anguillidæ, and even by Rotifera. And Fungi originate more or less clearly defined galls. Unquestionably it may be con- 
cluded that the origin of so many gall-structures by so many differently constructed insects-by insects differing in mode of oviposition, in habits and form of larvæ, \&c.-is hardly explainable by any one theory. Thus the instrument of oviposition in some gall-making beetles is the mouth; with most insects it is the ovipositor; while the Aphidæ cause gall-structures apparently by sucking the plants to obtain food for themselves and progeny. Even in the Hymenoptera we find two radical distinctions in habits of the insects, as has already been pointed out (vol.ii, p. 185), - that is to say, in the Tenthredinidæ the gall is already formed before the larva quits the egg; while in the Cynipidæ the birth of the larva is synchronous with the formation of the gall-until the larva is born and commences feeding there is no gall-formation.

Let us see what takes place when a Cynips oviposits in the leaf or bud, as the case may be. What is the first factor in gall-formation? This ; the growth of the larva, as has already been pointed out. The second is that the egg must be laid in, or in contact with, the cambium layer. The cambium layer is the seat of active growth in the plant. It is formative, not formed matter. It is most active naturally in the spring. The catkin galls are quickest in coming to maturity, the birth of the larva and gall and its development to the fly state occupying only a few days. The galls formed on the young leaves are not much behind the catkin ones in rapidity of growth; while, on the other hand, those found on the bark or roots take many months in coming to maturity. Whenever the larva ceases feeding no further growth takes place on those galls which remain attached, except with twig galls like those of Andricus inflator, which continue growing along with the twig long after the fly has escaped. On the other hand, there are galls which drop off in an immature state in the autumn, resuming growth in the spring. Even some of the succulent galls can be detached before maturity without their development 
being stopped, provided they are kept in the open air and supplied plentifully with moisture.

When the larval irritation sets in there is clearly a flow of sap to the affected part, and that, too, in greater abundance than to those parts not affected. The irritation continues with the growth of the gall, and the gall assumes very rapidly a definite form. It is conceivable that the mode of irritation may not be uniform in all species, and obviously the results produced cannot be alike when applied to different parts of a plant. We cannot conceive of galls formed on catkins, or young or even old leaves, having the same complicated structure as those in direct relationship with the woody tissues. In other words, the seat of origin of the gall has necessarily a direct relation to its morphology and form. I do not think that the form of the ovipositor has anything to do with the matter ; for although we do find considerable diversity in the egg-laying apparatus, yet that diversity has relation to the position in which the eggs are to be laid-those ovipositing in buds, for example, requiring a longer ovipositor to enable them to pierce the scales than a species laying eggs in leaves. There is also a difference in the form of the egg; yet that also has reference to the position in which they are placed, as explained when treating of the eggs. Of any difference in the form of the larva we have no evidence; and certainly the wound made by the ovipositor, per se, cannot be held accountable for the growth of the gall, for the latter may take weeks or even months after being in the plant before it grows.

As for there being any evidence of a chemical or molecular difference in the fluid which the gall-flies undoubtedly secrete, there is none whatever. LacazeDuthiers, arguing from the unquestionable fact that the venom of wasps and bees differed in strength as shown by its different degrees of virulence, concluded that a like diversity existed in the gall-fly venom. It must, however, be remembered that the function of 
the venom of gall-flies and wasps is different, it being in the latter for defence or offence against other insects. Apart from strength of virulence, it may also be stated that there is a chemical difference in some wasp venom, as is shown by some of them being more alkaline, in contradistinction to the usual acid nature of most species. But, as regards the Cynipidæ secretion, we have no evidence of any chemical or molecular difference; while the analogy to contagia is hardly applicable, since these are living organisms which cause changes in the animal system by their growth and multiplication. The only information we have of the nature of the gall-fly venom is that given by Beyerinck,* who describes it as tasteless and smell-less, and as a substance which, when injected into the hand, produces no ill effect whatever, while the poison of wasps does so when injected in the same way; and, finally, we know from direct observation that its use is to close the hole made by the ovipositor when the eggs are laid. Again, Paszlavsky (Terms. Füzetek, v) states that he has seen Rhodites rosæ give out during oviposition a transparent fluid clear as water, which flowed over the branchlets and leaflets. Even in the Tenthredinidæ, where larval irritation can have nothing to do with the growth of the gall, apparently one of its uses is to keep the wound made by the saw for the reception of the eggs from closing in and crushing them.

So far, therefore, as regards the Cynipidæ we may conclude (1) that there is no evidence that the venom has anything to do with the origin of the gall,on the other hand, there is every reason to believe that its use is to close the wound; and (2) that as observation shows that the mechanical irritation produced by the birth and growth of the larva is the primary factor in gall genesis, we may fairly conclude that the theory of mechanical irritation is more in consonance with observed facts than the infection one.

* Ueber d. ersten Entwick. einiger Cynipidengallen, p. 179. 
How we are to account for the origin of the sawfly galls is a question difficult of explanation. There can be here only three factors: (1) the wound made by the saw ; (2) the growth-the swelling up-of the egg; and (3) the venom ejected by the fly. Beyerinck, it may be added, adopts the latter theory for the sawfly galls.

So far as my observations go, I do not find any marked difference in the mode of oviposition of the gall and non-gall making saw-flies. I have noticed with some of the latter incipient gall-formation following oviposition. No doubt the distinction between the two lies in the fact that the former brings its eggs in contact with the cambium layer, the latter not.

The larval irritation theory may further be supported by the observation of the distortion and enlargements caused in galls by the inquiline flies.

Further information on this matter may be had in the above-mentioned memoir of Lacaze-Duthiers, Recherches pour servir à l'histoire des galles, l. c.; by M. W. Beyerinck, Beiträge tot de Morphologie der Plantengallen, 1877, and in his Beobachtungen über die ersten Entwickelungsphasen einiger Cynipidengallen, 1882; in Frank's Die Krankheiten der Pflanzen, Breslau, 1881; Meyer, Pflanzen-Pathologie, 1841 ; Courchet, Étude sur les Galles causées par les Aphidiens, Acad. d. Sciences et Lettres de Montpellier, 1881; and Hollis, Trans. Linn. Soc., 1875, who gives an admirable historical résumé of the subject.

\section{Food Plants.}

Apart from the oak, the food plants of the European Cynipidæ are-

Rosa canina, eglanteria, rubiginosa, spinosissima, \&c., attacked by the various species of Rhodites.

Rubus fruticosus, \&c., by Diastrophus rubi. 
Potentilla argentina, by Diastrophus Mayri, Reinh. - reptans, by Xenophanes potentillæ, Devil.

- - - foveicollis, Thoms.

\section{- tormentilla, by - brevitarsis.}

Acer pseudo-platanus, by Pediaspis acerina, Bremi. Lapsana communis, by Limaspis lapsanæ, Karsch. Phonixopus (Lactuca) vimineus, by Limaspis phonixopodus, Mayr.

Centaurea scabiosa, by Phanacis centaureæ, Foerster; Aulax scabiosæ, Gir.; and A. Rogenhoferi, Wachtl.

- salamatina, by Aulax Lichtensteini, Mayr.

- jacea, paniculata, and scabiosa, by Aulax jaceæ, Schenck.

Hieracium boreale, \&c., by Aulax hieracii.

Tragopogon major and orientalis, by Aulax tragopoginis, Thoms.

Hypochæris radicata, by Aulax hypochæridis, Kieffer. Artemisia, by Aulax artemisix.

Serratula heterophylla, by Aulax serratulæ, Mayr.

Salvia officinalis, by

Scorzonera humilis, by

Glechoma hederacea, by

Nepeta pannonice, by

Papaver rhoeas, by

Linaria vulgaris, by

Valerianella olitoria, by

Cytisus capitatus, by

Fagus, by

Pinus, by

Vitis, by

Pteris aquilina, by Triticum repens, by
- salvix, Gir.

- scorzoneræ, Gir.

- glechomæ, Htg.

- Kerneri, Wachtl.

- minor, Htg.; and papaveris, Perris.

- hieracii.

- valerianellæ,Thoms.

- hieracii.

Biorhiza aptera.

Diastrophus rubi. Aulax hieracii.

Obs. The root form of Pediaspis sorbi is stated by its discoverer, Tischbein, to form galls on the roots of Sorbus aucuparia; but Mayr (Eur. Cyn., p. 2) does not mention Sorbus as a food plant, giving Acer pseudoplatanus as the host for both forms. 
Mr. A. R. Rolfe (Ent., xiv, 54, and xvi, 29) records finding at Kew, on-

Quercus toza, Bosc., \&c.-Neuroterus lenticularis, N. baccarum, and Cynips Kollari.

Q. lusitanica-N. lenticularis, N. baccarum, N. fumipennis, N. numismatis, and Dryophanta divisa.

$Q$. lusitanica, var. infectoria-N. numismatis, $N$. lenticularis, $N$. ostreus, $N$. baccarum, and Andricus curvator.

Q. lusitanica, var. Turneri-N. numismatis, $C$. Kollari, and D. longiventris.

Q. glandulifera, Bl. (Japanese evergreen oak) - Neuroterus baccarum, Andricus curvator, Andr. gemma, $D$. divisa.

Q. Farnetto-N. lenticularis.

The galls of $N$. lenticularis, it may be added, on Q. cerris, are at $\mathrm{Kew}$ of a deep pink or purple colour, quite different from anything found on the native oak. I am indebted to Mr. Rolfe for the specimens figured in Pl. VIII, fig. 4.

\section{Synopsis of the British Galls.}

1 (2) On plants other than oak.

2 (9) On Rosa.

3 (4) Large, polythalamous, covered with long reddish hair.

4 (3) Small, on leaves, without hair.

Rhodites rosæ.

5 (6) The gall with four or five stout spines.

6 (5) The gall without spines.

7 (8) Spherical, regular, lightly attached to the leaf, falling off, not grown into the tissue of the plant; monothalamous, polythalamous when inhabited by Periclistus caninæ. On common rose.

R. eglanteriz.

8 (7) Irregular, on the leaves or twigs, grown into the woody part of the plant, usually not becoming detached. On $R$. spinosissima. $\quad$ R. spinosissimæ.

9 (10) On Rubus. Large strumous enlargements of the stem.

10 (13) On Compositæ.

Diastrophus rubi.

11 (12) On various species of Hieracium. Swellings on the stem.

12 (13) On Hypochæris. Long spindle-shaped swellings on the stem. Aulax hypochæridis. 
13 (14) On Centaurea scabiosa. Large swellings on the stems.

Aulax scaliosæ.

14 (17) On Potentilla. Irregular swellings as regards form and size on the leafstalks and stolons.

15 (16) On Potentilla tormentilla.

16 (15) On P. reptans. $\quad X$. potentillæ.

Xenophanes brevitarsis.

17 (18) On Nepeta glechoma. Irregular soft swellings on the stem and leaves. Aulax glechomæ.

18 (19) On Papaver. In the capsules, which may or may not be swollen. Aulax papaveris.

19 (20) On Triticum. Swellings on the roots. Aulax hieracii.

20 (110) On the common oak (Q. sessilifiora or Q. pedunculata).

21 (45) Situated on the under side of the leaf.

22 (27) Round, soft, and succulent, green or white, often with rosy cheeks.

23 (26) Appearing in the spring or early summer; diameter not more than $6 \mathrm{~mm}$.; green, projecting a little through the upper side of the leaf.

24 (25) Smooth, glabrous, length $5-6 \mathrm{~mm}$. Neuroterus baccarum.

25 (24) Covered with long white hairs. Length $4 \mathrm{~mm}$. N. tricolor.

26 (23) Appearing in the autumn; whitish-yellow. Diameter 8$12 \mathrm{~mm}$.

Dryophanta foli.

27 (28) Oval or ovoid, smooth, glabrous, pallid green or yellow, or brownish-yellow, spotted with pink dots, moderately hard, situated on the veins between two brownish sheaths, which remain after the gall has fallen; in Angust and September. $\quad$ Andricus ostreus.

28 (29) Reniform, small, green, succulent, usually crowded together ; September and October. Length 1-2 mm.

Trigonaspis renum.

29 (36) Semi-spherical; hard and woody; depressed at top and bottom.

30 (31) Without gloss, the skin rough with projecting points, whitishyellow, often with red rings or spots. Length $5-7 \mathrm{~mm}$.

Diyophanta longiventris.

31 (30) Smooth, without warts or bands or reddish rings.

32 (33) Gall with two chambers; cylindrical-spheroidal, flattened above, with a raised point in the centre; under side concave.

33 (32) Gall with one chamber.

Dryophanta disticha.

34. (35) Very shining, broader than high, the sides usually more or less reddish ; larval chamber small, the walls thick.

D. divisa.

35 (34) Not very shining, higher than broad, the sides without red, the larval chamber large, the walls thin. D. agama.

36 (29) Flat, lenticular, circular, often irregrular.

37 (38) Sunk, as it were, in the surface of the leaf, not projecting much on either side, circular, green, with striæ proceeding from the centre to the circumference; May and June.

Neuroterus vesicatrix.

38 (37) Not sunk in the leaf, but attached to it by a point; frequently gregarious; in the autumn.

39 (40) Round, depressed in the centre, covered with golden silky depressed hair. $\quad N$. numismatis.

40 (39) Flat, not covered with golden hair. 
41 (42) Almost glabrous, whitish-yellow to red, the centre raised, the margin turned up, irregular, scattered on leaf,

N. læviusculus.

42 (41) Covered with stellate hair's ; gregarious.

43 (44) The sides flat, not distinctly curled up; the top broadly concave; the bottom glabrous, pale yellow, seldom red.

N. lenticularis.

44 (43) The sides curled up; the top concave; the bottom pilose; red or brownish-red.

N. fumipennis.

(52) Situated on the margin of the leaf, without an inner gall.

(47) Smooth, ovoid. glabrous, seed-like, greenish-yellow. Length $1-2 \mathrm{~mm}$.; in June and July.

Neuroterus albipes.

(46) More or less spindle-shaped or oblong.

48 (49) Shortly stalked, green, often with red longitudinal lines; the apex ending in a point. Length $6-8 \mathrm{~mm}$.; in October.

49 (48) Not stalked. Andricus seminationis.

50 (51) The surface granular, shining, greenish-yellow, often reddish, spotted with small pale spots, brownish when old. Length $4 \mathrm{~mm}$.; in May, on young half-grown leaves.

Dryophanta verrucosa.

51 (50) The surface glabrous, irregularly ribbed or keeled longitudinally, green. Length $4-5 \mathrm{~mm}$.; in June and July, in fully developed leaves'

Andricus marginalis.

52 (53) An irregular, often globular or oval swelling at the base or footstalk of the leaf, green, smooth; a large central cavity, containing a small, brown, ovoid, seed-like, free inner gall.

And. curvator.

53 (54) A small elongate swelling on the midrib or leafstalk.

54. (53) In the leaf-buds.

Andricus testaceipes and $A$. noduti.

55 (56) Polythalamous, large (often 1 inch in diameter), whitishyellow, soft and spongy, in the terminal buds. May and June.

Biorhiza terminalis.

56 (55) Monothalamous, not spongy in texture.

57 (62) In twigs on the trunk or near the ground, soft.

58 (59) Bare, roundish, soft, whitish with reddish cheeks; usually found near the ground among moss in May, on adventitious buds. Length $5-7 \mathrm{~mm}$. Trigonaspis megaptera.

59 (58) Pilose, ovate.

60 (61) Violet, sometimes bluish-green, covered with a very short velvety pubescence; in June. $3 \mathrm{~mm}$. 61 (60) Greenish or greyish-green, covered with longish white hair ; in May and June. $2 \mathrm{~mm}$.

62 (86) In twigs on the branches.

63 (64) Large, round, greenish to yellow, with red cheeks when young, brown when old, not falling off when mature. Length from $10 \mathrm{~mm}$.

Cynips Kollari.

64 (63) Small, dropping off when mature, elongate or ovate.

65 (68) Covered with hair.

66 (67) Spindle-shaped; not pedunculate; covered densely with long, woolly, brownish-white hair. Length $5-8 \mathrm{~mm}$. 
67 (68) Not spindle-shaped; the base dilated; covered with white silky depressed hair; the larval chamber separated from the bottom by a hollow space. And. glandula.

68 (65) Glabrous.

69 (72) Spindle-shaped, with a more or less longish peduncle; green, often with reddish lines.

70 (71) The peduncle as long or nearly as long as the gall; JuneAugust. Length 7-12 mm.

71 (70) The peduncle very short; October. $6-8 \mathrm{~mm}$.

72 (69) The galls oval or oblong, or irregular.

And. Malpighii.

78 (78) The galls not at all enveloped in the leaf-buds.

74. (75) The gall very small (about $1-2 \mathrm{~mm}$.), ovoid, granular, green ; June. $\quad$ And. gemmatus.

75 (74) The gall not small, oblong, longer than broad.

76 (77) Green, spotted with white, the apex without a sharp point. Length 5-6 mm. ; May and June. And. albopunctatus.

77 (76) Not spotted with white, covered with short whitish hair; finely rugose, often keeled, brownish-yellow, reddish when young.

78 (79) More or less enveloped in the leaf-buds.

79 (80) The gall completely enveloped in greatly developed leafscales, forming a miniature artichoke-like body. Length from $20 \mathrm{~mm}$. And. fecundatrix.

80 (79) The gall not completely enveloped in the leaf-scales.

81 (82) Irregularly pea-shaped, thin-walled; green or yellowishwhite; in April or beginning of May; not much enveloped in the leaf-scales, not woody. And. aprilinus.

82 (81) Globular or ovoid, tapering towards the apex, hard and woody, appearing in the autumn.

83 (84) Globular, 3-4 mm., green and smooth when fresh, when old reticulated; its apex only appearing out of the bud, blunt, usually yellowish.

84 (83) Oroid, the apex sharply pointed. $2-3 \mathrm{~mm}$.

And. globuli.

85

(86) The apex with a distinct nipple-like point, of a darker colour than the rest of the gall.

(85) The apex not ending in a dark nipple-like point.

And. collaris.

(88) The apex of a terminal twig inflated, the inflationnalis. than broad, the cavity large, containing a loose small brownish inner gall.

(89) The twigs or leafstalk, or the midrib An. curvator and inflator. which cause more or less perceptible irregular swellings.

89 (94) On the roots.

And. noduli.

90 (91) Polythalamous, large, brown, irregular, from one to three inches in length.

And. radicis.

91 (92) Monothalamous, situated on the rootlets, often in clusters, irregular in shape.

92 (93) In the bark, on the thick roots, or on the trunk, where there is a wound, the gall sunk in "the young wood, cupshaped, conical at apex, the top falling off when old.

And. corticis.

93 (92) A swelling on the trunk where a wound has been, not differing from the root-galls.

And. radicis. 
94. (95) On young branches, covcred with earth or vegetation, gregarıous, conical, hard, woody, deeply furrowed, reddish and juicy when young, giving out an exudation.

And. Sieboldii.

95 (109) On the catkins.

96 (99) The galls small and enveloped in a mass of woolly hair.

97 (98) The mass of hair large, dense. From $20 \mathrm{~mm}$.; June.

And. ramuli.

98 (97) The mass of hair small, not dense; in May and June.

99 (96) The galls not enveloped in a mass of woolly hair.

And. cirratus.

100 (101) The galls pilose, brownish.

And. amenti and A. pilosus.

101 (100) The galls glabrous.

102 (103) Globular, succulent, green with reddish cheeks.

Neuroterus baccarum.

103 (104) Spindle-shaped, shortly pedunculated; green, tinged with red.

And. seminationis.

104 (103) Oblong or oval.

105 (106) Irregular, the sides more or less keeled.

106 (105) The sides kecled or furrowed all over; the base not contracted. Length $3 \mathrm{~mm}$.

And. quadrilineatus.

107 (104) The sides with only one stout keel, the base contracted. Length about $1 \mathrm{~mm}$.

A. Schlechtendali.

108 (103) Oval or oblong, regular, the sides not keeled; 1-2 mm.

109 (95) In the young half-developed acorns, which"are A. nudus. distorted.

Andricus?

110 (20) On Quercus cerris.

111 (110) In the acorns.

112 (111) On the catkins, very irregular, massed together.

113 (110) In the leaf-buds, elongate-ovate, about 2.5 less gregarious.

$\mathrm{mm}$; more or And. circulans.

\section{Collecting, Preserving, and Breeding of Gall-flies.}

The imagos may readily be collected by beating the food plants over an umbrella, or by sweeping under or on them. They may be preserved either by gumming them on cards, or (and, in my opinion, far better for purposes of examination) by sticking them on fine pins or on silver wire, the latter being inserted into small pieces of the pith of the Jerusalem artichoke. The objection to the carding is that the face is hidsometimes an important organ to examine; while, again, it may be necessary to see the mesopleura.

In view of the fact that so many of the species are so much alike-indeed, in many cases not discernible in the perfect state from each other-the breeding of 
the flies from the galls is a matter of great importance; to rear them is not always an easy matter. Probably no rearing case is better than ordinary jelly-cans whose tops have been ground smooth, so that a glass plate may fit them closely. In these cans should be placed sand, which has been thoroughly boiled or burnt to destroy any organic matter there may have been in it. When this has been moistened the pots are fit for use.

In selecting galls for rearing purposes one point must be kept in view, namely, that only mature galls should be selected to rear from; for it is practically useless to attempt breeding from half-grown galls, although it must also be said that by keeping some semi-developed galls moistened and exposed to the atmosphere they may grow even when detached from the plant. Still the rule must be, only attempt breeding from mature galls. The spring galls do not afford much difficulty. The chief point is to see that they are not kept too moist, and this may be aroided by taking the lid off the case occasionally, because, if this is not done, the galls are very liable to turn mouldy. On the other hand, care must be taken that they do not turn too dry; if this happens the galls shrink up and destroy the insects.

The autumnal galls give much more trouble than the spring, as might be expected from the longer period they remain in the galls, especially those which come out in the spring. With these there is only one way of successfully rearing them, and that is to keep them outside, exposed to all the atmospheric changes. In rearing from the galls of the autumnal Neuroteri it must be recollected that when they fall from the leaves in the autumn they are not fully. developed; but by keeping them outside, and with plenty of air and moisture, they will be devoloped all right in the spring.

In breeding gall-flies great care must be taken to keep each species in a separate pot, or otherwise grave errors may be made in the records of the rearings 
of parasites and inquilines. The latter, it may be added, are much more easily bred than the gall-flies themselves.

\section{Classification.}

The origin of the name "Cynips" has been already discussed (vol. iii, p. 140). Westwood was the first who separated generically any of the species from Cynips by forming the genus Biorhiza. Hartig added ten more, namely, Andricus, Neuroterus, Teras, Rhodites, Diastrophus, Spathogaster, Trigonaspis, Aulax, Ceroptres, and Synergus, the last two being inquiline species, as he was the first to discover. Hartig's primary generic character was the length of the radial cellule and the position of the areolet; next followed the form and number of the joints of the antennæ; while for subsidiary characters he took the form of the scutellum, the texture of the thorax, and the number of joints in the maxillary and labial palpi. In 1859 (Verh. z.-b. Ges. Wien) Giraud erected the genus Dryocosmus, and ten years later Foerster formed some more genera, and brought the whole to a focus according to the lights of his time. His synoptical table is here reproduced:

1 (42) Wingless or winged; in the latter the areolet lies quite close to the base of the radial cellule.

2 (5) Wingless.

3 (4) Antennæ 14-15-jointed.

4 (3) Antennæ 13-jointed.

5 (2) Winged.

6 (13) Radial cellule closed on the fore margin.

7 (10) Scutellum with an impression.

8 (9) The first abscissa of the radius angular, broken.

9 (8). The first abscissa of the radius only slightly elbowed.

Biorhiza, West. Apophyllus, Htg.

10 (7) Scutellum without an impression.

11 (12) Radial cellule short and broad.

$12(11)$ - - elongate.

13 (6) - $\quad-$ open at fore margin.

14 (15) Mesonotum without parapsidal furrows. Ameristris, Foer.

15 (14) - with parapsidal furrows.

Bathyaspis, Foerst.

16 (21) Foveæ at the base of scutellum united. 
17 (18) Scutellum laterally margined.

Dryocosmus, Gir.

18 (16) - not margined.

19 (20) Mesonotum quite smooth, with complete deep parapsidal furrows; scutellar foreæ in front transverse.

Entropha.

20 (19) Mesonotum not completely smooth, the parapsidal furrows not deep; scutellar foveæ in front curved.

Spathogaster, Htg.

21 (16) Scutellar foveæ separated.

22 (25) The first and second joints of the flagellum equal, or the first shorter than the second.

23 (24) Antennæ with the o 14-, with the of 13-jointed; the first two joints of the flagellum unequal ; basal fovea of scutellum very large; radial cellule not twice as long as wide. Isocolus.

24. (23) Antennæ with the $\delta 15$., with the o 13-jointed; the first two joints of flagellum of equal length; basal forea of the scutellum small; radial cellule twice longer than wide.

25 (22) The first joint of flagellum longer than the second. Synophrus.

26 (27) The second joint of hinder tarsi not as long as the last.

27 (26) The second tarsal joint as long as the last.

28 (29) Metanotum very strongly declivous; the apex of the scutellum lying very high over the base of the abdomen ; the first joint of the flagellum very strongly incised at the apex, much broader than at the base.

Trigonaspis.

29 (28) Metanotum not very strongly declivous; the apex of the scutellum not very high over the base of the abdomen; the first joint of the flagellum at the apex not broader than at the base.

30 (33) Mesunotum quite smooth.

31 (32) Face sharply striated; central area of mesonotum with a more or less complete central furrow.

Diastrophus.

32 (31) Face not striated; middle lobe of mesonotum without a central furrow.

Liodora.

33 (30) Mesonotum not quite smooth.

34. (37) Mesonotum alutaceous, rugose, bare or shortly haired; the apex of the abdomen not bearing silky hair ; the antennæ and legs not stiffly haired.

35 (36) Mesonotum transversely rugulose.

36 (35) - not transversely rugulose.

Callirhytis. thickly with long hairs. punctured, not rugulose; covered more or less

$37(34)$

38 (39) Abdomen at the apex covered with silky, woolly hairs.

39 (38) - - - not covered with silky, woolly hairs.

40 (41) Antennæ and legs with coarse, stiff, erect hairs. Dryophanta. 41 (40) - - - without coarse, stiff, erect hairs.

42 (1) Winged, seldom wingless; the areolet lying distant from the base of the radial cellule.

43 (54) The second abdominal segment at the base smooth, without furrows.

44 (47) The second abscissa of the radius curved; radial cellule at the base and apex open; areolet absent.

VOL. IV. 
45 (46) Scutellar foveæ reaching to the middle of the scutellum; radial area at the base, not curved; the second and the following segments finely punctured.

Eubothrus.

46 (45) Scutellar foveæ not reaching to the middle of the scutellum; radial cellule at the base sinuately enlarged. Liposthenus.

47 (44) The second abscissa of the radius not curved; radial cellule at the base and apex closed ; areolet present.

48 (51) Radial cellule on the fore margin closed.

49 (50) Mesopleuræ striated ; the first and second joints of the flagellum equal in length.

Periclistus.

50 (49) Mesopleuræ alutaceous; the first joint longer than the second.

51 (48) Radial cellule open.

52 (53) Mesonotum quite smooth.

$53(52)$

54 (43) The second abdominal segment striolated.

55 (56) Radial cellule open.

$56(55)$ - - closed.

Phanacis.

Obviously the discovery already alluded to by Adler of the occurrence of alternation of generation in the family upset the older genera, and made a revision in view of the new facts imperative. This needful work was admirably done by Professor G. L. Mayr, of Vienna. His synopsis of the genera, so far as our Fauna is concerned, is as follows :

\section{Synopsis of the Genera as defined by Professor Mayr*.}

\section{Females.}

1 (4) Wingless.

2 (3) Furrows of the parapsides complete; antennæ 14-jointed; a short, thickish keel between the antennæ; head swollen behind the eyes; ventral spine $1-1 \frac{1}{2}$ times longer than broad. Biorhiza.

3 (2) Furrows of the parapsides incomplete; antennæ 13-14-jointed; no keel between the antennæ; head not swollen behind; ventral spine $2-2 \frac{1}{2}$ times longer than broad. Trigonaspis.

4 (1) Winged.

5 (6) Petiole rugosely longitudinally striated; the second and third abdominal segments without any visible suture; face obliquely striated; frontal keels usually reaching to the ocelli; radial cellule closed; antennæ 14-jointed. Synergus.

6 (5) Petiole smooth, not striated ; frontal keels absent.

7 (8) Face with two distinct paraliel keels going from the antennæ to the base of the clypeus; antennæ 12-jointed; scutellum with two fover at the base; third abdominal segment longer than the second, closely united, but still with the suture

* Die Genera der Gallen bewohnenden Cynipiden, Wien, 1881. 
visible; the third segment covering the greater part of the abdomen; radial cellule closed; claws bifid. Ceroptres.

8 (7) Face without keels.

9 (10) Hypopygium ploughshare-shaped, ending in a sharp point and without a distinct ventral spine; mesopleuræ with a distinct longitudinal furrow, sometimes punctured; radial cellule completely closed; claws simple.

Rhodites.

10 (9) Hypopygium not ending in a sharp point; incised beneath, and having a ventral spine.

11 (12) Scutellum not separated from the mesonotum by a suture; no ridge-like border behind the depression at the base; parapsidal furrows absent, or, if present, only reaching to the middle; antennæ and tibiæ not hairry ; antennæ 13-15. jointed.

Neuroterus.

12 (11) A suture between the mesonotum and scutellum; a ridge-like border behind the foveæ.

13 (14) Abdomen, especially from the third segment to the apex, closely covered with silky hair; antennæ, head, and legs completely pilose; head not swollen behind; parapsidal furrows complete; scutellum broader than long, with two fover at the base.

14 (13) Abdomen not silky haired.

Cynips.

15 (16) Cheeks with a sharp furrow; antennæ 14-jointed; the flagellum thin, attenuated towards the apex; parapsidal furrows sharp and complete; mesonotum polished; foveæ at base of scutellum separated by a sharp keel; metanotum with two curved carinæ; second joint of tarsi as long as the terminal, claws bifid; abdomen red.

Trigonaspis.

16 (15) Cheeks without a furrow; the apex of flagellum not thinner than the middle.

17 (18) Front, vertex, mesonotum, and mesopleuræ shining, smooth, glabrous; antennæ 13-14-jointed; scutellum with two sharply separated foveæ at base; pronotum with two small foveæ near the middle; metanotum with two parallel carinæ; claws simple.

18 (17) Head and nesothorax not shining and polished.

Xestophanes.

19 (20) Second and third abdominal segments without a suture, so that there are only six segments apparent; cheeks without furrows; face laterally striated; head not swollen behind the eyes; metanotum with two parallel keels; pronotum not narrowed in the middle, and with two not very distinct keels; mesonotum finely punctured and pilose; antennæ 12-jointed, the third joint shorter than the fourth or equal to it; claws bifid.

20 (19) Second and third abdominal segments not united.

21 (24) Cheeks more than half as long as the eyes, without a furrow; last joint of the flagellum not thicker than the fifth or sixth; pronotum scarcely narrowed in the middle; parapsidal furrows complete; two sharply separated foveæ at base of scutellum; ventral spine at the most scarcely longer than broad; antennæ 13--14-jointed; radial cellule short, broad.

22 (23) Claws bifid; mesonotum polished. Diastrophus

23 (22) Claws simple; mesonotum closely shagreened or punctured, opaque. Aulax. 
24 (21) Cheeks half as long as the eyes ; apical joints of flagellum thicker than the fifth or sixth; pronotum small; radial cellule long, narrow, open.

25 (26) Base of scutellum with two sharply separated foveæ; carinæ of metanotum straight and parallel, seldom curved or diverging towards the apex; parapsidal furrows sharp and complete; antennæ and tibiæ not covered with hairs, the third joint longer than the fourth. Andricus.

26 (25) Base of scutellum with a transverse furrow, or with two sharply separated foveæ; in the latter case the keels on metanotum curred.

27 (28) Claws single; antennæ and tibiæ not covered with stiff hairs; base of the scutellum with two foveæ; mesonotum polished; body yellowish.

Biorhiza.

28 (27) Claws bifid; antennæ and tibiæ closely covered with stiff hairs ; a transverse furrow at base of scutellum; the agamic form hairy, especially on the legs and antennæ; thorax opaque, shagreened; sexual form polished, glabrous.

Dryophanta.

Males.

1 (2) Petiole rugosely longitudinally furrowed; face sharply striated; frontal keels seldom short and indistinct; radial cellule closed; antennæ 15-jointed, third joint sometimes enlarged.

2 (1) Petiole not longitudinally furrowed.

Synergus.

3 (4) Face with two parallel keels between the antennæ and clypeus; antennæ 15-jointed, the third joint enlarged and as long as the fourth; base of scutellum with two foveæ; metanotum with two parallel carinæ.

4 (3) Face without keęls.

5 (6) Mesopleuræ on lower side with a stout, often punctured or reticulated longitudinal furrow; third antennal joint the longest; radial cellule closed; claws simple. Rhodites.

6 (5) Mesopleuræ without a longitudinal furrow.

7 (8) No transverse keel behind the depression at base of scutel. lum; abdomen petiolated; parapsidal furrows absent or indistinct.

8 (7) A transverse keel behind the fover at base of scutellum.

9 (10) Cheeks with a sharp furrow; antennæ longish, thin, 15jointed, the joints at least three times as long as thick; mesonotum polished; the furrows complete; metanotum with two keels ; two fover at base of scutellum, separated by a sharp keel.

10 (9) Cheeks without a furrow.

Trigonaspis.

11 (12) Second and third abdominal segments amalgamated, with scarcely a trace of suture; abdomen not petiolated; antennæ 14-jointed; radial cellule closed; claws bifid; mesonotum finely rugosely punctured.

Periclistus.

12 (11) Second and third abdominal segments not closely amalgamated; the suture quite distinct.

13 (14) Vertex, front, mesonotum, and mesopleuræ polished, glabrous ; pronotum with two fover in front, polished between them; antennæ 14-jointed; claws simple; radial cellule open in front. 
14 (13) Only the mesonotum polished; pronotum without foveæ.

15 (18) Cheeks at least half as long as the eyes; the radial cellule not usually elongated; abdomen not petiolate.

16 (17) Claws bifid; mesonotum shining, impunctate; antennæ 14jointed.

Diastrophus.

17 (16) Claws simple; mesonotum shagreened, opaque; antennæ 1415-jointed. Aulax.

18 (15) The cheeks less than one-half longer than the eyes; radial cellule open, longish, narrow.

19 (20) Keels of mesonotum straight and parallel or very short; antennæ 14-15-jointed ; parapsidal furrows complete, deep; two distinctly separated foveæ at base of scutellum; abdomen scarcely petiolated.

Andricus.

20 (19) Keels of median segment hardly curved; antennæ 15-jointed.

21 (22) Reddish-yellow; antennæ thick, third joint longer than fourth ; strongly emarginated; mesonotum shining; claws simple; abdomen scarcely petiolated.

Biorhiza.

22 (21) Mesonotum not reddish-yellow; the antennæ thin, the third joint emarginate; abdomen petiolated; claws bifid.

Dryophanta.

Obs.-The male of Cynips is unknown.

\section{Genus Rhodites.}

Rhodites, Hartig, Germs. Zeit., ii, 186 ; Mayr, Genera, 18.

Hololexis, Foerster, Verh. z.-b. Ges. Wien, 1869, 330.

Apical ventral segment elongate, ploughshare-shaped, ending in a sharp point. Antennæ 14-15-jointed, situated above the middle of the face; the flagellum filiform, its first joint longer than the second. Radial cellule completely closed, short, the areolet when present placed close to its base. Cheeks without furrows, as long or nearly as long as the space from the bottom of the eyes to the top. Head not dilated behind the eyes. Parapsidal furrows complete, or obliterated in front. Scutellum large, bifoveate or not at the base. Mesopleuræ with a longitudinal furrow extending from the fore to the middle coxæ (except with the American $R$. dichloceros, O. S.), the furrow rugosely punctured.

The of has the third antennal joint curved, and is very rare, the genus, in fact, being more or less parthenogenetic. The areolet is present or absent; and the wings are more or less infuscated, seldom clear hyaline. The head and thorax are black, but the abdomen is frequently yellowish.

Without exception the species are found as gallmakers on roses. Six or seven species are known from Europe, and about the same number from North America.

Rhodites is a very easily recognised genus; the 
ploughshare-shaped apical ventral segment and the longitudinal furrow on the mesopleuræ being two points in which it differs from all the other genera.

Hololexis, Foerster, merely differs from Rhodites in having the radial cellule elongate in opposition to the short and broad area of Rhodites, eglanterix being a typical form of it.

A. Radial cellule elongate; the basal abscissa of the radius curved, not angled; cubitus obsolete.

\section{Rhodites eglanteria.}

Pl. XI, fig. 3, gall ; Pl. XII, fig. 8, .

Rhodites eglanteriæ, Htg., Germ. Zeit., ii, 194; Schenck, Nass. Cyn., 92, 93, and 123; Mayr, Cyn., 19, Taf. iii, fig. 15; Europ. Cyn., 3 ; Taschen., Hym. Deut., 135 ; Thoms., Opusc., viii, 792 ; Fitch, Trans. Essex Field Club, ii, 125 , fig. 7 .

Hololexis eglanteriæ, Foer., Verh. z.-b. Ges. Wien, 1869, 333.

Black; abdomen and legs reddish-yellow, the latter paler in tint than the former ; the abdomen at the apex and beneath more or less blackish, the legs at the base more or less blackish, the tarsi infuscated; wings smoky, with a griseous tinge; antennæ blackish to brown, longish, slender, the third joint about one third longer than the fourth. Shining; the mesonotum aciculated laterally; the scutellum finely rugose, the basal foveæ indistinct; parapsidal furrows complete, narrow.

The $\delta$ has the abdomen with more black than red.

Length $2.5-3.5 \mathrm{~mm}$.

Easily known by the elongated radial cellule, and by the curved basal abscissa of the radius.

Gall.-Pea-shaped, with a diameter of from 3 to 5 mm.; smooth, or more seldom beset with little tubercles; green, frequently with reddish cheeks, or more rarely reddish entirely; sometimes greenishyellow. They are found either on the upper or lower side of the leaf, and may even occur on the leaf-stalk; they are attached only by a small point to the stalk or 
leaf-vein, and the attached part does not show on the other side of the leaf by a projection. The inner cell is large, the bounding wall of parenchymatous cells being thin, seldom being much more than $1 \mathrm{~mm}$. in thickness.

When the galls have been attacked by the inquiline Periclistus caninx they become larger, more irregular, and instead of having one large cell they contain several, united by a spongy tissue (see Pl. XI, fig. 3).

The galls are usually found on Rosa canina, less frequently on $R$. rubiginosa, and I once found them on $R$. eglanteria and $R$. spinosissima. When ripe the galls fall to the ground, and give forth the insect in the following spring.

The galls of Rhodites centifolix (a species not yet found in this country) cannot, so far as I can make out, be distinguished from those of $R$. eglanterix. The galls of the former, however, are said to be found only on the leaves of Rosa centifolia.

$R$. (Hololexis) rufipes, Foerster, is said also to have galls like those of $R$. eglanteriæ; but it is difficult or impossible to say wherein the differences between the galls or insects lie.

Parasites. - Hemiteles imbecilus, Gr.; Torymus difficilis, Nees.; T. congener, Foer.; T. viridis, Foer.; T. eglanteriæ, Mayr; Oligostenus stigma, Fab.; Eulophus inunctus, Nees.; Pteromalus inflexus, Foer.; Tetrastichus longicaudatus, Ratz.; T. obtustatus, Gir.; T. rosarum, Foer.

Brischke (Schr. d. Naturf. Ges. z. Danzig v.) records Torymus auratus, T. tipularum, Zett., Tetrastichus leptoneurus, Pteromalus pilosus (T. pilosellus?), T. incrassatus, Ratz., T. Neostatensis, Ratz., Eurytoma rosæ, and Orthopelma luteolator.

Commonly distributed in Britain.

Continental distribution: Sweden, Germany, and Holland. 
B. Radial cellule short, triangular; the basal abscissa angled or elbowed in the middle; the areolet present.

1 (4) Legs for the greater part red.

2 (3) Abdomen reddish, the radial cellule with a smoky fascia.

3 (4) Abdomen blackish or brownish-black ; the radial cellule without a smoky fascia.

4. (1) Legs for the greater part blackish.

Spinosissimæ. Nervosus.

\section{RHODITES ROSA.}

Pl. X, fig. 2, galls ; Pl. XIJ., fig. 10, ơ; $10 a$, head.

Cynips rose, Linn., S. N., ii, 917 ; Fab., E. S., ii, 100, 2; S. P., $143,1$.

Diplolepis bedeguaris, Geof., H. I., ii, 310, 2.

Rhodites rosæ, Htg., Germs. Zeits., ii, 194; Schenck, Nass. Cyn., 92, 122; Tasch., Hym. Deut., 134; Marshall, E.M.M., iv, 173; Mayr, Cyn. Gall., 15, pl. xv, fig. 12; Europ. Oyn., 4 and 5; Thoms., Opusc., viii, 791; Osten Sacken, Proc.Ent. Soc.Phil.,1863,40; Fitch, Trans. Essex Field Club, ii, 126, fig. 6.

Black; abdomen red, with the apex black; legs reddish, the base more or less black; wings somewhat irregularly griseous, the apex from the base of radial cellule infuscated or brownish. Vertex and mesonotum opaque, closely and finely aciculate; the third antennal joint twice the length of the fourth.

The $\delta$, has the abdomen for the greater part black, the second antennaljoint as long as broad; the legs are more broadly black at the base than in the $o$.

Length 3.5 to $4.5 \mathrm{~mm}$.

The maker of the well-known "bedeguar" or pincushion galls of the common rose. They form a woody mass on the stem, either low down or terminal in position; contain numerous cells, and are covered all over with long greenish to reddish moss-like hair. In size they are about an inch on the average in diameter, but may be smaller or greater. Occasionally single galls, either abortive or containing only one cell, are met with on a leaf. The explanation of the galls being found on a leaf is that the gall really originates from a leaf, and not from a bud or stem, as might at first thought be ex- 
pected. According to Paszlavsky * the normal bedeguars originate from three leaflets, and possibly the explanation of the finding of the small more or less abortive galls on a leaf is to be found in the fact that the eggs were laid in one leaf only.

There is a variety on the Continent which is quite glabrous. I believe I once found it in Scotland, but at the time took it for a curious variety of $R$. spinosissimæ.

As with most of the species which form manycelled galls, the labour of oviposition is long and laborious.

The bedeguar was formerly used medicinally, and, according to the late $\mathrm{Mr}$. Ashmead (as quoted by A. Müller, Zool. s. s., p. 1206), the farmers at Harrogate gather them to make an infusion for the cure of diarrhœa in cows.

$R$. rosæ has the $\delta$, in comparison with the $q$, exceedingly rare; and there can be no doubt, from the observations of Adler (D. E. Z., xxi, 209), that it is parthenogenetic. This also appeared to be the case in America, for, according to Osten Sacken (Proc. Ent. Soc. Phil., 1863, p. 47), out of 200 specimens he only got one $\delta$. It is attacked by numerous parasites, namely, Porizon harpurus, Gr.; Hemiteles luteolator (very abundant); Torymus longicaudis, Ratz.; T. purpurascens, Fab.; T. bedeguaris, L. ; T. rosarum, Gir.; T. macropterus, Ratz. ; Eupelmus Degeeri, Dal.; Oligostenus stigma, Fab.; Pteromalus fuscipalpis, Foer.; $P$. inflexus, Foer.; P. pilosus, Ratz.; P.festivus, Foer.; Eurytoma abrotani, Ill.; E. rosæ, Nees.; E. æthiops, Ratz.; and, as inquiline, Periclistus Brandtii, Htg. Brischke (Schr. d. Naturf. Ges. z. Danzig v.) gives as parasites Eupelmus Bedeguaris, Eurytoma nodularis ; and, as inquiline, Synergus ruficornis, Htg.

Of universal distribution in Europe; found also in North America (see Osten-Sacken, Proc. Ent. Soc. Phil., 1863, p. 40).

* Terms. Füzetk, v. 
3. RHODITES SPINOSISSIMæ.

Pl. XI, fig. 5, gall ; Pl. XII, fig. 7, + .

Rhodites spinosissimæ, Giraud, Verh. z.-b. Ges. Wien., 1859, 367 ; Schenck, Nass. Cyn., 92, 94, and 124; Taschen., Hym. Deut., 135 ; Mayr, Cyn. Gallen, 16, pl. ii, f. 13 ; Europ. Cyn., 3 and 4.

Black ; the abdomen black or fuscous-black, the legs pale yellowish, the coxæ blackish at the base, the hind femora infuscated above in the middle; wings hyaline, a little infuscated in the middle. Vertex and mesonotum finely punctured and shagreened; the antennæ stoutish, the third joint twice the length of the fourth; scutellum opaque, finely rugose.

Length 2 to $2 \cdot 5 \mathrm{~mm}$.

Easily known by the dark abdomen and hyaline unspotted wings. The $\delta$ I have not seen.

The gall of this species is hard, woody, and very irregular in form. It occurs both in the leaves and stem, and in either case forms an integral part of the plant, in the latter part extending frequently to the pith, and firmly embedded in it. It is polythalamous. Some of the galls are as regular and spherical as those of $R$. eglanterix, and of about the same size; but, generally speaking, it is very seldom that we find them so regular as those of the last species, while the galls of the latter are distinguished by being only very slightly attached to the plant and readily dropping off. They may occupy almost entirely one side of a leaf, and part of the leaf may extrude through the gall (see Pl. XI, fig. 5). In certain cases when this happens the gall has the appearance of several galls being amalgamated. On the stem the galls form irregular pithy swellings. They may project through both sides of the leaf or on one only; they may occupy the entire leaf except a fringe of it; may be smooth or bear little projections, or even spines; in colour may be green, dull red, or very fiery red. Besides being on the leaves and twigs they also occur on the leaf-stalk, on the flower-buds, even on the 
petals. As a rule polythalamous, specimens are sometimes found with only one cell. I have found three separate monothalamous galls on one leaf. Those on the twigs remain attached; those on the leaves fall with them, and apparently the gall-bearing leaves drop off earlier than the others.

In this country I have only found the galls on Rosa spinosissima, on which along our shores it has a wide distribution, being found from Sutherlandshire to the south of England. On the Continent it has been found on $R$. canina.

Mr. Inchbald (Zool. S. S., 7824) describes a "Cynips rosæ-spinosissimæ," which I cannot identify satisfactorily from the shortness of the description: "Colour black; antennæ geniculate, hairy; head and thorax dull black, pitted and dotted over with pale pile; abdomen shining black; legs black, with the tarsi paler. Insect much smaller than Cynips rosæ." It is evidently not spinosissimx, Gir., nor does it agree with the species of Periclistus.

As parasites it has Torymus macropterus, T. difficilis, Nees., Megastigmus transversus, Walker, Pteromalus inflexus, Foer., P. incrassatus, Ratz. (Brischke); Tetrastichus aurantiacus, Ratz., T. rosarum, Foer.; and as inquiline Periclistus caninæ.

Continental distribution: Germany.

\section{RhOdites NeRvosus.}

Pl. XI, fig. 4, gall ; Pl. XII, fig. 9, + .

Rhodilus nervosus, Curtis, B. E., 688, pl. cccxx ; Marshall, E. M. M., iv, 174 .

Rhodites rosarum, Giraud, Verh. z.-b. Ges. Wien, 1859, 366 ; Schenck, Nass. Cyn., 92, 94, and 129; Taschen., Hym. Deut., 135 ; Mayr, Cyn. Gallen, 18, Taf. iii, f. 18 ; Europ. Cyn., 3 ; Fitch, Trans. Essex Field Club, ii, 125, fig. 7. Cf. also Gray, Proc. Ent. Soc., 1858 , p. 94 .

Black; the fore-legs with the knees and tibiæ pale ochreous; the middle tibiæ usually obscure reddish-yellow; the hind legs dark 
fuscous or brownish; abdomen yellowish-red, the hypopygium brownishblack; wings pale fuscous, the nervures brownish, shining; the mesonotum closely aciculate; the parapsidal furrows distinct, and there is a short furrow between them at the base; scutellum finely rugose, irregularly keeled, projecting at the base between the foveæ. The third antennal joint hardly one-fourth longer than the fourth. o .

Length 3 to $3.5 \mathrm{~mm}$.

The cubitus is usually present, but may be very faint; the keels on the scutellum are not so well developed in the smaller as in the larger examples; the quantity of yellow on the four anterior legs varies, and some specimens have the wings more deeply suffused than others.

The ${ }^{*} \mathrm{I}$ have never seen, nor has it been described by any author.

Gall.-Irregularly pea-shaped, bearing five or less stout, sharp-pointed spines, smaller, as long, or longer than the gall itself; smooth, sometimes bearing small warts; green, spotted with red when old, and becoming brownish when they fall from the leaf. In diameter they vary from 4 to $6 \mathrm{~mm}$.; they are unicellular, the cell large, the bounding wall being about $1 \mathrm{~mm}$. in thickness. The gall is attached by a narrow point to the leaf-vein on the under side, the mark of attachment not being visible on the upper side of the leaf. It is found in July, and falls to the ground when ripe.

When attacked by Periclistus caninæ the galls are larger, more irregular, usually paler, and are polythalamous, as in Rhodites eglanterix. The parasites are Torymus macropterus, Pteromalus eminens, Foer., P. inflexus, Foer., Tetrastichus obtusatus, Gir.

The galls have been recorded from Rosa canina, $R$. arvensis, $R$. rubiginosa, and $R$. causacica. I believe I once found them on $R$. eglanteria.

I think there is no doubt about this being nervosus. Curtis's description is as follows: "Black, shining, obscurely punctured, and slightly pubescent ; antennæ 14-jointed, as long as the body, two basal joints brownish; ocelli very large; post-scutellum rugose, with three parallel ridges; abdomen very smooth and 
ochreous, the lower sheath brown; wings pale fuscous, iridescent, the nervures brown, edges of the marginal cell suffused; anterior legs pale ochreous, intermediate brown, hinder piceous, base of all the thighs darker; apical joint of tarsi fuscous.

Distinguished from $R$. rosæ by the large ocelli, carinate scutel, dark hinder legs, the absence of the brown splash on the ocast of the upper wings, and of the areolet. July. Dover."

Gloucester, West Wickham, London district.

Continental distribution: Germany, Austria.

\section{Genus Aulax.}

Aylax, Hartig, Germ. Zeit., ii, 186.

Aulax, Mayr, Genera, 20.

Isocolus, Foerster, Verh. z.-b. Ges. Wien, 1869, 330.

Eubothrus, Foerster, l. c., 331.

Liposthenus, Foerster, 1. c., 331.

Head and thorax aciculate, coriaceous, or punctured. Cheeks without furrows, as long as the length of the eyes. Antennæ.13-14- $q$, o. 14-15-jointed, the third joint with the latter curved; the third joint may be longer or shorter than the fourth. Pronotum sometimes with two parallel keels in the middle. Parapsidal furrows complete. Scutellar fover distinct, clearly separated. Scutellum separated from the mesonotum by a furrow. The two keels on the median segment are either parallel or diverging at the apex. Abdomen sessile, seldom compressed, the second segment longer than the others, of different length. The radial cellule is of different lengths, broad at the base, open or more or less closed; the areolet present or absent. Claws simple.

The species of Aulax bear considerable resemblance to those of Synergus, but may easily be known by the petiole not being striolate nor two-jointed. They have the head and thorax black, with the abdomen and legs more or less testaceous or yellowish.

There are about a dozen European species known, which form gall-like swellings on various herbaceous plants.

The peculiarities of Foerster's Isocolus, Eubothrus, and Liposthenus (here sunk in Aulax) may be seen by reference to the table on pp. 33,34 . 


\section{A. Antennæ 14-jointed in + , 15-in 0 .}

1 (4) Mesonotum glabrous, shining, more or less impunctate in the centre.

2 (3) Antennæ brownish-red; scutellum rugose ; wings without areolet. Glechomæ.

3 (2) Antennæ black; scutellum not more strongly. sculptured than the mesonotum ; areolet present.

4 (1) Mesonotum pubescent, opaque.

Hypochæridis. Papaveris.

\section{Aulax glechome.}

Pl. X, fig. 1, gall ; Pl. XIII, fig. 1,

Aulax glechomæ, Htg., Germs. Zeits., iii, 342 ; Mayr, Cyn. Gall,, 7, Taf. i, f. 2; Europ. Cyn., 7; Thoms., Opusc., viii, 809; Fitch, Trans. Essex Field Club, ii, 130, fig. 15.

Diastrophus glechomæ, Schenck, Nass. Cyn., 90 and 126.

Liposthenus glechomæ, Foer., Verh. z.-b. Ges. Wien, 1869, 336. For gall cf. Réaumur, Ins., iii, pl. xlii, figs. 1-5; and Malpighi, Opera, pl. ix, fig. 24.

Black; the legs and antennæ yellowish-rufous; the scape blackish; the flagellum darker coloured than the legs; the coxæ brownish or blackish ; abdomen dark brown, the base more or less dark testaceous ; wings hyaline, the nervures fuscous; areolet obsolete. The centre of the mesonotum smooth and shining, the sides aciculate; glabrous, parapsidal furrows reaching to the middle; scutellum rugose, broadly depressed above. Propleuræ and mesopleuræ in front transversely striolate. $q$. The second segment forms at least two-thirds of the length of the abdomen.

Length $2 \frac{1}{4}$ to $2 \frac{3}{4} \mathrm{~mm}$.

The galls of this species are found on the leaves or stem of Nepeta glechoma, or on both. In shape they are very irregular; they may be spherical, pear-shaped, or of no definite form; they may occur singly or in groups, separated or united; in colour green-entirely green, or green with pink or red, this latter being more particularly the case with young species. They are covered with long white hair, but this gets rubbed off with age, and the galls are then glabrous. They are polythalamous. At first soft and succulent, with age they get hard and woody. 
They are found from June to September.

The galls of this species are eaten in France by the peasants, according to Réaumur (Mém., iii, p. 416). He says, "Dans certaines années où elle en étoit chargée, les paysans se font avisés de manger de ces pommes du lierre terrestre, et les ont trouvées bonnes. J'en ai goûté, leur faveur aromatique m'a paru tenir beaucoup de celle que l'odoratu fait imaginer que la plante doit avoir: au reste, il faut cueillir de ces galles de bonne heure, pour ne pas les avoir trop sèches et trop filamenteuses. Je ne scais pour tant si elles pourront jamais parvenir à être mises au rang des bons fruits."

The known parasites are Torymus splendens, $T$. glechomæ, Foer., T. cinqulatus, Nees., T. rosarum, Gir., Eupelmus brachypterus, Gir., E.Degeeri, Dalman, Pteromalus glechomæ, Foer., Tetrastichus glechomæ, Gir., Eurytoma rufipes, Brischke, and the ichneumon Pezomachus diastrophi, Gir.

Widely distributed in England and Scotland; also in the Isle of Man, where it was found by Miss Constance Abrahall.

Sweden, Germany, France.

Obs.-The Cynips glechomæ, Linn., is not this species, as is shown by the tel'ms "thorace villosa."

\section{AULAX HYPOCH ÆRTDIS.}

$$
\text { Pl. IX, fig. 5, gall. }
$$

Aulax hypochæridis, Kieffer, Verh. z.-b. Ges. Wien., xxxvii, 205

Black; antennæ filiform, 14-jointed, black, with a greyish pubescence; the third joint somewhat longer than the fourth. Face striated, the front and vertex shagreened. Thorax shining; mesonotum almost glabrous, very finely but clearly wrinkled. Scutellum without median furrow; at the base with two large foveæ; in front of the same sculpture as the mesonotum. Wings hyaline; radial cellule open at the base at top. Areolet distinct. Legs reddish-yellow; base of coxæ and tarsal joints black. Abdomen very shining (Kieffer).

Length $2 \cdot 1-2 \cdot 2 \mathrm{~mm}$. 
Galls take the form of spindle-shaped or oval swellings on the petioles of Hypochrris radicata, some of them reaching a length of $40 \mathrm{~mm}$. and a diameter of $7 \mathrm{~mm}$. In colour they do not differ from the stems, the swelling taking place in the pith. Internally they contain numerous oval cells, usually placed nearer the centre than the edges. The surface is smooth, or beset with little warts, and furrowed longitudinally; but the furrows are, of course, more widely apart, and wider and more irregular than in the unaffected parts of the stem.

Found in Wales by Dr. Vice, and also recorded from South Devon (cf. Briggs., Ent., 1875, p. 233).

Eurytoma cynipsea, Boh., is a parasite.

Continental distribution: Austria, Italy (cf. Löw, Verh. z.-b. Ges. Wien, 1884, 326).

\section{AUlax papateris.}

Pl. VIII, fig. 1, gall.

Diplolepis papaveris, Perris, Ann. Soc. Ent. Fr., 1839, 98.

Aulax rhoadis, Htg., Germs. Zeits., ii, 1846, 195 ; Schenck, Nass. Cyn., 96, 100, and 127; Tasch., Hym. Deut., 133 ; Mayr, Cyn. Gallen, 22, Taf. iii, f. 19; Europ. Cyn., 7; Thoms., Opusc., viii, 800 ; Westwood, Gard. Chron., 1885, p. 152.

- minor, Htg., Germs. Zeits., ii, 196 ; Mayr, Eur. Cyn., 7.

Black; the legs yellowish-testaceous; the abdomen brownish or black, the base often castaneous; the antennæ dark brown, almost black; wings hyaline, the nervures fuscous; areolet distinct. Mesonotum opaque, pubescent, closely and uniformly aciculate; pleuræ finely punctured; scutellum finely and closely rugose, sometimes furrowed in the centre; parapsidal furrows reaching beyond the middle. The $\delta$ has the coxæ, trochanters, and base of femora more or less blackish; in the $q$ also the base of coxæ may be infuscated.

Length $1 \frac{3}{4}$ to $2 \frac{1}{2} \mathrm{~mm}$.

In some examples the furiow on the scutellum is distinct enough, but it is absent in many.

I should say that A. minor, Htg., is only a var. of 
papaveris:; according to the diagnosis of Hartig and Mayr it simply differs from papaveris in the antennæ being "brown," often yellowish or reddish at the base, the scutellum without a furrow, and the abdomen in o more or less yellowish-red or castaneous-brown beneath. I find, however, so much variation on all these points, as also in size, among specimens reared from capsules collected at the same time, that I can scarcely look upon minor as a good species.

This insect galls in the seed-vessels of the poppy ( $P$. dubius and rhoeas). The capsules may be distorted and enlarged, or hardly at all. Internally we notice two changes : the entire gall may be converted (as in the typical papaveris, which is also enlarged) into a spongy mass, in which the round larval cells are irregularly embedded in the mass, the septa being entirely obliterated; or (as in the typical minor) the septa remain, and the larval cells are placed between and usually completely separated from each other; these capsules being very little, if at all, enlarged or distorted.

If distinct, both papaveris and minor are found in Britain.

The species has been found in Berwickshire by $\mathrm{Mr}$. James Hardy; at Hereford by Dr. T. A. Chapman; and Westwood records it from Guildford.

The parasites are Pezomachus papaveris, Foer.; Raptrocnemis papaveris, Foer.; Lochites papaveris, Mayr; Holaspis militaris, Boh.; Orymus papaveris, Perris ; Cerrospilus arcuatus, Ratz.

Continental distribution: Sweden, Germany, Austria.

\section{B. Antennæ, \& 12-13-, o 14-jointed.}

1 (2) The hinder margin of the fore wings ciliated; the abdomen more or less at the base and the legs reddish; the third joint of the antennæ longer than the fourth.

Hieracii.

VOL. IV. 
2 (1) The hinder margin of the fore wings not ciliated; abdomen entirely, and the legs for the greater part, black; scutellar foveæ large; the third and fourth joints of the antennæ about equal.

Scabiosæ.

\section{AULAX HiERAoit.}

Pl. IX, fig. 1 ; Pl. XI, fig. 1 (graminis); Pl. XII, fig. 11.

Cynips hieracii, Bouché, Naturg. d. Ins., 164.

Aylax sabaudi, Htg., Germs. Zeit., ii, 195.

Aulax hieracii, Schenck, Nass. Cyn., 99; Mayr, Cyn. Gallen, 9, Taf. i, fig. 4 ; Europ. Cyn., 8.

Aulax graminis, Cam., Proc. Nat. Hist. Soc. Glas., 1875, 322; Mayr, Cyn. Gallen, 6, fig. 1.

Black; the legs and the basal half of abdomen ferruginous; the antennæ dark ferruginous to brown, the basal two joints always darker than the others; the coxæ often more or less fuscous. Wings clear hyaline; the nervures pale fuscous; the apex ciliated; areolet present. Mesonotum sub.opaque, strongly aciculate; pleuræ aciculate; parapsidal furrows complete; abdomen shining, impunctate. $\dot{q}$ and $\delta$.

Length 2 to $2.8 \mathrm{~mm}$.

The amount of ferruginous colour on the abdomen and antennæ varies; in the $\delta^{\pi}$ the abdomen is usually entirely black.

In coloration it is not unlike $A$. papaveris, but the 13-jointed antennæ and the distinct parapsidal furrows separate it from the poppy species.

$A$. graminis cannot be distinguished by any characters, structurally or in coloration, from hieracii; and I am inclined to think that the two are identical notwithstanding that they are found on different plants. This seems the more likely from the fact that A. hieracii has been bred from galls on Linaria vulgaris and Cytisus capitatus (cf. Mayr, Eur. Cyn., 8).

The galls are found chiefly on Hieracium sylvaticum and $H$. boreale. They are found on all parts of the plant, but more particularly on the stem, not far from the flower-head. I have seen them also on the roots, and they may affect even the flowers. As may be seen by a reference to the figures on Pl. IX, in form they are very variable, this being also the case as 
regards size. They are hard, usually coloured like the stem, but with age get paler, and contain numerous larval cells of the usual form irregularly distributed through the mass. In size I have found them from a quarter to over an inch and a half in length. The outer surface is more or less thickly haired, but old examples are usually glabrous.

On Triticum the larvæ live in the roots, which they do not distort very much. Several live in cells together, as in Hieracium.

The parasites are Torymus hieracii, Mayr; T. chlorinus, Foer.; T. euchloris, Bohm. ; T. rubi, Schr.; Eurytoma signata, Nees; E. flavo-scapularis, Ratz.; Decatoma hieracii, Gir.; Systole castaniventris, Gir.; Tetrastichus quercûs, Walker; Pteromalus aurantiacus, Ratz.; Tetrastichus Andrewii, Ratz.; T. planiusculus, Foerster.

The species is of wide distribution in Britain and in Europe.

\section{Aulax soabioser. \\ Pl. XI, fig. 2, gall.}

Diastrophus scabiosæ, Giraud, Verh. z.-b. Ges. Wien, 1859, 368. Isocolus scabiosæ, Foerster, 1. c., 1869, 334.

Aulaw scabiosæ, Mayr, Eur. Cyn., 10; Cyn. Gallen, 11, fig. 6. Aulax centaureæ, Thoms., Opusc. Ent., 809, 19.

Black; the knees, tibiæ, and tarsi ferruginous; wings hyaline; the nervures reddish; the arenlet absent; the fore wings not ciliated. Head and thorax opaque, transversely rugose; the face and pleuræ aciculated. Scutellum coarsely rugose, without a longitudinal furrow. Abdomen shining; the second abdominal segment at the apex and the following distinctly punctured. Antennæ blackish; the third and fourth joints subequal. Median segment and collar covered with greyish pubescence.

Length $3 \mathrm{~mm}$. $q$.

The gall is found as large, strumous, spindleshaped swellings on the stems of Centaurea scabiosa. These may be as long as two or three inches, and contain numerous cells scattered irregularly through the medullary tissue. 
Foerster founds his "genera" Isocolus and Eubothrus on this species.

The species has only been found at Tapley Pike, near Buxton, in this country (cf. Fitch, Ent., x, p. 124).

Continental distribution: Sweden, Germany, Austria.

\section{Genus Xestophanes.}

Xestophanes, Foerster, Verh. z.-b. Ges. Wien, 1869, 337.

Antennæ $q$ 13-14-jointed. Face, occiput, mesonotum, and mesopleuræe shining, glabrous. Scutellum with two distinct foveæ; two minute fover on the pronotum in the middle behind. Parapsidal furrows abbreviated or entire. Median segment with two parallel keels. Radial cellule short, broad, open at fore margin, closed at base. Second and third abdominal segments united, sometimes with a furrow. Abdomen for the greater part, and legs pallid. Claws of fore tarsi entire. The $\delta$ with the antennæ 14-jointed; the third joint curved.

The species of this genus are confined to Potentilla. From the allied genera it is readily recognised by the glabrous shining head and mesothorax.

Besides our two species only one other is known, namely, $X$. foveicollis, 'Thoms., which differs from them in having the pronotum and metathorax "dense griseo-tomentosis."

1 (2) Third antennal joint not longer than the fourth; fourth joint of hinder tarsi longer than wide; parapsidal furrows incomplete.

Potentillæ.

2 (1) Third antennal joint perceptibly longer than the fourth; fourth joint of hinder tarsi not longer than wide; the parapsidal furrows complete.

Brevitarsis.

\section{Xestophanes potentillet.}

Pl. XII, fig. 3 , q . $3 a$, antenna ; $3 b$, hind tarsus. Pl. XVII, fig. 1, gall.

Cynips potentillæ, De Vill., Linn. Ent., iii, 77. Aylax splendens, Htg., Germs. Zeits., ii, 196.

Aulax potentillæ, Schenck, Nass. Cyn., 96, 99, and 126; Marshall, E. M. M., iv, 275 (?); Mayr, Cyn. Gallen, 12, Taf. ii, fig. 9; Europ. Cyn., 10.

Aulax abbreviatus, Thoms., Opusc. Ent., 1877, 805. 
Black, shining, impunctate; the abdomen and legs reddish-yellow, the latter paler in tint than the abdomen, the former more or less infuscated above towards the apex; wings hyaline; the nervures fuscous; antennæ brownish, fuscous at the apex; parapsidal furrows obsolete in front; the third joint of the antennæ not perceptibly longer than the fourth; the fourth joints of the hinder tarsi twice longer than broad. In the of the second abdominal segment is shorter, in the $\delta$ longer, than the third.

Length 1.5 to $2.5 \mathrm{~mm}$.

The galls are found on the stems and leaf-stalks of Potentilla reptans. They form irregular swellings, usually of numerous cells, which may or may not project as roundish protuberances from the general mass. In texture they are hard and woody ; in colour they may be greenish, reddish, or purplish at first, becoming brownish with age. They may form spindleshaped swellings of from 10 to $15 \mathrm{~mm}$. in length, but also they may be spherical or oval; and, as in brevitarsis, small isolated single cells may be found. They may occur singly or in groups from the roots upwards, and a series of small galls may be united to form a necklace-like body.

Diastrophus Mayri, Reinh., forms somewhat similar swellings on the stem of Potentilla argentea.

Cynips brevicornis, Curtis (B. E., 688, 19), clearly represents either potentillæ or brevitarsis, but which I cannot make out to my satisfaction. His description is "Black, shining; abdomen bright ferruginous; legs bright ochreous; tips of tarsi fuscous ; mandibles and antennæ ferruginous, the latter brownish towards the apex; not much longer than the head and thorax; 13-jointed ; terminal joint longest. $1 \frac{1}{3}$ lines.

\section{"Dover."}

As parasites there have been recorded Torymus globiceps, Nees, T. ater, Nees, Oligosthenus tibialis, Eulophus nitidulus, Eurytoma abrotans, Nees, Encyrtus zephyrinus, Dalman, Siphonura brevicauda, Nees, Pezomachus potentillæ, Gir. Thomson (Opus. Ent., 804) records Eurytoma rufipes from his Aulax foveifrons. 
The species is found in Devonshire and Kent. Continental distribution: Sweden, Germany.

\section{Xestophanes BRevitarsis.}

\section{Pl. IX, fig. 3, gall ; Pl. XII, fig. 12, antenna ; $12 a$, tarsus.}

Aulax brevitarsis, Thoms., Opusc., 1877, p. 805.

Xestophanes tormentillæ, Schlecht., Ent. Nach., 1880, p. 176; Mayr, Eur. Cyn., 10.

Similar in coloration and size to $X$. potentillæ, but readily separated from it by the third antennal joint being perceptibly longer than the fourth, by the parapsidal furrows being complete, and by the fourth joint of the hinder tarsi being hardly longer than wide.

Length $2 \cdot 2 \mathrm{~mm}$. $q$.

The gall is found on the stems of Potentilla tormentilla, on which they may occur singly as oval or spherical swellings, or a number may be loosely or tightly massed together. Some of the larger masses are not distinguishable from the galls of $X$. potentilla on $P$. reptans. The colour is at first green, then purple or brownish, and they are slightly pubescent. The average length of an individual gall is about $3 \mathrm{~mm}$. ; the conglomerated galls may reach a length of $20 \mathrm{~mm}$.

Of wide distribution in Scotland.

Continental distribution: Sweden, Germany, Austria.

\section{Genus Periolistos.}

Periclistus, Foerster, Verh. z.-b. Ges. Wien, 1869, p. 337.

Antennæ, ㅇ 12-, o 14-jointed, filiform, the third joint usually shorter than the fourth. Face striolate laterally. Pronotum with two diverging carinæ. Mesothorax finely punctate or alutaceous, pubescent. Scutellum with two well-marked foveæ. Parapsidal furrows straight, parallel. Anterior claws bidentate. Radial cellule open at fore margin. The second and third abdominal segments united. Median segment with two parallel keels. 
The species of this genus are inquilines in the galls of Rhodites and Diastrophus. They are black, with the legs reddish-yellow, the abdomen blackish or brownish, and the mesothorax is pilose.

Only two European and four North American species are known.

1 (2) Parapsidal furrows reaching almost to the base of the mesonotum ; mesopleuræ completely striated.

Brandti.

2 (1) Parapsidal furrows incomplete; mesopleuræ with a clear, shining, impunctate space.

Canina.

\section{Periolistus Brandti.}

\section{Pl. XIII, fig. 2, o .}

Cynips Brandti, Ratzeburg, Berl. Jahr. d. Pharnn., 1832; Brandt and Ratzeburg, Medic. Zool., ii, $1833,151$.

Aulax Brandti, Htg., Germ. Zeits., ii, 196; Schenck, Nass. Cyn., 96 and 97 ; Marshall, E. M. M., iv, 274; Mayr, Europ. Cyn., 11 ; Thoms., Opusc., viii, 800 .

Black; the legs reddish-yellow, the coxæ blackish, the antennæ blackish; head and thorax opaque, rather strongly aciculate, the parapsidal furrows reaching to the base of the mesonotum or nearly so.

The $\delta$ has the antennx testaceous, except the base and apical joints, which are darker coloured.

Length $2 \cdot 5$ to $3 \mathrm{~mm}$.

A larger and stouter species than caninæ, and easily distinguished from it by the presence of the parapsidal furrows.

An inquiline in the galls of Rhodites rosæ.

I have seen several examples from England, but have no record of the precise locality. I have taken it in Clydesdale. On the Continent it is found in Sweden and Germany. 


\section{Periclistus caninet.}

Pl. XIII, fig. 3 , $q$.

Aylax caninæ, Htg., Germs. Zeits., ii, 196 ; Schenck, Nass. Cyn., 96 and 98; Tasch., Hym. Deut., 133; Mayr, Europ. Cyn., 11; Thoms., Opusc., viii, 800 .

Black; the antennæ brownish or fuscous, darker at the scape; the legs pale reddish-yellow, the coxæ for the greater part black, opaque, finely shagreened; the mesopleuræ for the greater part shining and impunctate behind.

The $\delta$ is similar, and has generally the antennæ more or less testaceous at the base.

Length $1 \cdot 5$ to $2 \mathrm{~mm}$.

Common in the galls of Rhodites eglanterix, several living in one gall, which they enlarge and distort.

Widely distributed.

Sweden, Germany.

\section{Genus SaPHoLtTus.}

Sapholytus, Foerster, Verh. z.-b. Ges. Wien, 1869, 337; Mayr, l. c. $x \times i i, 693$.

Agrees with Synergus except that the radial cellule is open, and like that genus it is inquiline in oak-galls. The frontal groove is short; the marginal nervure does not reach to the margin of the wing.

Besides the one here recorded there are two other European species, namely, S. Haimi, Mayr, from galls on the Turkey oak, and S. undulatus; also on the Turkey oak in Cynips cerricola.

\section{Sapholytus connatus. \\ Pl. XIII, fig. 5, + .}

Synergus connatus, Htg., Germs. Zeits., ii, 198.

erythroneurus, Htg., 1. c., 198.

Sapholytus connatus, Mayr, Verh. z.-b. Ges. Wien, xxii, 722 ;

Thoms., Opusc. Ent., 798. 
Black; the antennæ and legs rufo-testaceous; the coxæ and hind femora more or less blackish; wings hyaline; the nervures pallidyellow; front very finely punctured, almost smooth; mesonotum finely transversely rugulose. Antennæ, o 13-, $\delta$ 15-jointed ; the third joint not twice the length of the fourth. Apex of petiole smooth. Frontal keels obsolete.

Length 1-2.5 $\mathrm{mm}$.

I have two bred males with the hinder tibiæ infuscated.

Rare in galls of Andricus noduiti, Clydesdale.

Sweden, Germany, Austria.

\section{Genus Ceroptres.}

Ceroptres, Hartig, Germ. Zeit., ii, 186.

Face with two distinct parallel keels, proceeding from the antennæ to the clypeus. Antennæ with 12 joints in $q, 15$ in $\delta$; the antennæ in o thickened towards the apex; the third joint as long as the fourth ; in not incised or thickened. Pronotum in front with two acute converging keels. Parapsidal furrows incomplete. The scutellar foveæ small and indistinct. Median segment with two parallel straight keels and with a squarish median area. The second and third abdominal segments connate, occupying almost the whole abdomen ; in the $o$ the second segment is shorter than the third. Radial cellule closed. Claws bifid.

The separating suture between the second and third abdominal segments is not easily seen, and was overlooked by. Hartig.

The systematic position of Ceroptres has given rise to some divergence of opinion as to its affinities. Hartig, as was pointed out (vol. iii, p. 152), divided the family into two groups according as the second or third abdominal segment was the larger of the two. Hartig himself, not recognising the suture between the second and third segments, looked upon them as one only, and consequently he located Ceroptres with the gall-making and inquiline species. Schenck and Foerster, however, were aware of the presence of this suture, and seeing that the second segment was shorter than the third transferred Ceroptres to the Figitina, with which otherwise it has no affinity, either in habits or in its general body structure. We have, 
however, already pointed out that the relative lengths of the second and third abdominal segments cannot be regarded as a character of prime importance for purposes of classification, inasmuch as there are genuine gall-makers, e.g. Xenophanes, which have the second shorter than the third. We therefore follow Hartig, Mayr, and Thomson in retaining Ceroptres near the gall-makers and Synergi, with which in other respects it has so many points of agreement.

Mayr describes in his Monograph only two species, namely, $C$. arator and $C$. cerri; but Hartig described C. clavicornis, C. melanonerus and socialis, forms which the learned Austrian Hymenopterist was unable to recognise.

\section{Ceroptres arator.}

Pl. XIII, fig. 4 , $q$; $4 a$, antenna.

Ceroptres arator, Htg., Germs. Zeits., iii, 343 ; Mayr, Verh. z.-b. Ges. Wien, xxii, 724, 1.

Black ; the antennæ and legs yellow; the scape and coxæ more or less black; wings hyaline, the nervures testaceous. Head and mesonotum finely punctured, shining, abdomen impunctate, very shining, the base ferrugineous, pilose laterally. The face bears two acute longitudinal keels.

Length 1-2 $\mathrm{mm}$.

The other European species of Ceroptres (C. cerri) is not likely to occur in this country, being found only in the galls of the Quercus cerris.

I have only seen specimens from Clydesdale in the galls of Andricus noduli. Billups (Proc. Ent. Soc., 1884,14 ) records rearing it from the galls of Cynips Kollari.

Sweden, Germany, Austria. 


\section{Genus Strnergus.}

Synergus, Hartig, Germ. Zeit., ii, 186 ; Mayr, Genera, 3.

Face with coarse, oblique, radiating furrows. Petiole rugosely distinctly longitudinally striolate. Radial cellule closed. The second and third abdominal segments connate. Cheeks without a furrow; longer than the eyes. Antennæ, o 14-, $\delta$ 15-jointed, the third joint in the latter curved, sometimes enlarged; spindle-shaped. Parapsidal furrows complete. Median segment with two parallel keels. Abdomen compressed. Claws cleft. The front with a pair of keels which usually reach near to the lateral ocelli.

The sculpture of the thorax varies from alutaceous to rugose; the mesosternum is striolate; the second and third abdominal segments amalgamated, seldom with the suture visible.

The general features relating to the history of the guest gall-flies have been already indicated. They issue earlier into the fly state than the insects on which they prey, a circumstance, indeed, rendered necessary from their having to deposit their eggs in the galls when these are very young. As a rule they distort the galls to a more or less extent, and it is probable that many of the abortive galls owe this fact to the action of the inquilines. They may either enlarge or reduce the gall. A well-marked example of the former we have in Rhodites eglanterix; of the latter Neuroterus ostreus may be cited, but in this case apparently only one larva has been in it, or at least has come out of the gall. When several live in one gall, say in Dryophanta divisa, they are separated from each other by partitions apparently formed of the substance of the gall and some secretion of the larva. As has already been pointed out, the larger galls may afford nourishment to the maker and to one or more inquilines, while it is of not uncommon occurrence for a gall to yield inquilines and chalcid parasites, the latter having preyed upon one of the inquiline larvæ.

The inquilines, as has been indicated by Mayr, are divisible, as regards habits, into two groups, namely, those which winter in the galls, $i . e$. those 
which oviposit in autumnal galls, leaving them early in the spring; and those which live in the spring galls, leaving them in July or about that time, the latter species living in the galls only a short period compared to those which winter. Whether all the summer broods live in two distinct galls, a spring and autumn one, is not clear. A species like $S$. radiatus might well live in the galls of Neuroterus baccarum in May, come forth and oviposit in Andricus solitarius, remaining in this gall to the following spring, if it were not the fact that it issues from Andricus solitarius in July of the same year.

Our winter galls are-

$$
\begin{array}{cl}
\text { Synergus melanopus. } \\
\text { - } & \text { Reinhardi. } \\
\text { - } & \text { apicalis. } \\
\text { - incrassatus. } & \text { Tschelii. } \\
\text { - } & \text { pallicornis. } \\
\text { - nervosus. } & \text { tristis. } \\
\text { - } & \text { vulgaris. } \\
\text { - } & \text { thaumacera. }
\end{array}
$$

The spring species are-

$$
\begin{aligned}
& \text { Synergus albipes. } \\
& \text { - facialis. } \\
& \text { - } \quad \text { radiatus. } \\
& \text { - thaumacera. }
\end{aligned}
$$

The last-mentioned species is stated by Mayr to winter in the galls of Biorhiza renum.

It is difficult to find a group of Hymenoptera wherein the separation of the species is more perplexing, or where the specific characters are more plastic. There is hardly a single specific point wherein we do not find extreme variability. Colour we could hardly expect to find very stable in those insects ; and, indeed, the amount of variation in this respect in all the species is very great and often ex- 
cessive. The sculpture of the thorax might be held at first sight to afford some criterion of specific distinctness; but experience and observation show that the difference in this respect is very great indeed. In species like $S$. incrassatus, for example, the normal coarsely coriaceous sculpture of the thorax may be alutaceous merely, particularly in smaller-sized specimens. Indeed, the intensity of sculpture appears to have some relationship to the amount of nourishment the larva has had, abundant food yielding large specimens, poor and insufficient food small and stunted examples. It is not easy to find even structural characters which are constant. Thus the length of the second antennal joint in normal specimens of $S$. melanopus gives a fairly good specific character; but in abnormal examples it does not, as they have it as in S. Reinhardi. The form of the radial cellule is not of much importance, while the colour of the nervures is very inconstant. Further, the frontal laminæ in stunted examples become very indistinct, however well marked they may be in larger forms. On the other hand, the species oviposit with tolerable constancy in the same galls; and in truth it is only by rearing the species that undoubtedly typical examples are to be had.

Mayr in his excellent monograph describes twenty. two European species; besides which there are a few species described by Hartig which he was unable to determine to his satisfaction. The genus is, as might be expected, common in North America, and is also known from Mexico.

\section{A. Second abdominal segment at the apex, broadly and closely punctured.}

1 (2) Second antennal joint in $\delta$ shorter than broad, in $q$ as broad as long; head reddish, black on the top (typical form only). Melanopus.

2 (1) Second antennal joint in $\delta$ and $q$ longer than broad.

Reinhardi. 
There are five other species of this group, namely, S. evanescens, Mayr, from galls of Andricus gemmæ and other Continental species ; S. pallidipennis, Mayr, from galls of Cynips lignicola and $C$. conifica, $C$. tinctoria, and C. coriaria; S. flavipes, Htg., from galls of Dryophanta macroptera; S. Hayneanus; Htg., from galls of Cynips tinctoria and $C$. lignicola; and $S$. ruficornis, from galls of Andricus globuli. All the species overwinter in the galls.

\section{Synergus melanopus.}

$$
\text { Pl. XII, fig. 5, ㅇ. }
$$

Synergus melanopus, Htg., Germs. Zeits., iii, 1841, 347 ; Mayr, Verh. z.-b. Ges. Wien, xxii, 695 . Diplolepis rufipes, Fonsc., Ann. Soc. Nat., 1832, 193 (nec Fal.), Synergus orientalis, Htg., l. c., 347.

$$
\text { socialis, Htg., l. c., iv, } 413 .
$$

Black; the head rufous, the vertex and occiput in the centre, black; legs rufous, the coxæ for the greater part, the front femora slightly at the base, the intermediate to the middle (generally), the greater part of the posterior and the greater part of the hind tibiæ, blackish, or fus. cous; abdomen more or less brownish to ferruginous; antennæ rufous, the apical half more or less infuscated. Front rugosely punctured; mesonotum coarsely and rugosely transversely striolated, the space between the striæ smooth or nearly so, the striæ interrupted by the parapsidal and central furrows. Petiole strongly punctured behind; second antennal joint about as long as broad. Frontal laminæ straight, reaching to the hinder ocelli; facial keel obsolete; apex of second segment of abdomen closely and distinctly punctured.

The $\delta$ has the second antennal joint shorter than broad, the third thickened and curved. I have seen males with the femora without any black.

Length $2-5 \mathrm{~mm}$.

The best character to distinguish typical examples of this species from S. Reinhardi is to be found in the longer second antennal joints of the latter. The rufous colour of typical Melanopus is characteristic, but on the other hand the head may be entirely black. The length of the second antennal joint in the male and female is not constant, and may take the proportion it has in Reinhardi; the legs may be 
entirely rufous except at the base; the abdomen may be more or less rufous and punctured at the base; the quantity of testaceous or rufous colour on the antennæ varies, and, as in most of the species, the size and deepness of the puncturing varies.

In this country it has only been reared from the galls of $C$. Kollari, but on the Continent it frequents the galls of Cynipsargentea, C. hungarica, C. tinctoria, C. lignicola, C. conglomerata, C. glutinosa, C. coriaria, C. polycera, C. caliciformis, C. amblycera, C. caputmedusæ, C. calicis; Aphilothrix gemmæ, A. lucida, and $A$. Clementinæ.

Rare in this country. Clydesdale. London district (Billups), Devonshire (Bignell).

Continental distribution: Austria and Hungary, Germany.

\section{Synergus Reinhardi.}

Synergus Reinhardi, Mayr, Verh. z.-b. Ges. Wien, xxii, 698.

Black; the antennæ, except at the apex, all the knees, the apex of the front femora, the fore tibiæ and tarsi, the middle tibiæ and tarsi in front, and more or less of the hind tarsi, rufo-testaceous; wings clear. hyaline; the nervures pallid to the radial cellule, then fuscous; radial cellule shortish, wide, the radial nervure curved. Vertex closely r'ugosely punctured; mesonotum coarsely, transversely, rugosely punctured in front and laterally, at apex transversely striolated. Facial keel very distinct; frontal laminæ stout, parallel, not reaching to the hind ocelli. Second antennal joint longer than broad. Nervures fuscous to testaceous.

Length $2.5-3.5 \mathrm{~mm}$.

One of the largest species. The c? has the second antennal joint longer than thick.

From galls of C. Kollari in June of the second year ; in Austria found in the galls of Cynips argentea, $O$. tinctoria, C. glutinosa, C. caliciformis, C. caput-medusæ, C. calicis.

I have taken it in Clydesdale and Sutherlandshire, and Mr. Bignell has bred it at Plymouth.

Continental distribution: Austria. 
B. Second abdominal segment, if punctured at all, only on the upper side at the apex.

\section{Synergus apichlis.}

$$
\text { Pl. XII, fig. 2, }+
$$

Synergus apicalis, Htg., Germs. Zeits., iii, 349; Mayr, Verh. z.-b. Ges. Wien, xxii, 705 ; Thoms., Opusc., $796,7$.

- immarginatus, Htg., l. c., 348.

- erythrostomus, Htg., l. c., 348.

Black; the oral region and the lower part of the face and cheeks and legs pale rufo-testaceous; the antennæ testaceous at the base, the rest infuscated; the coxæ black, the basal half of the fore and the greater part of the hind femora infuscated; the hind tibiæ slightly infuscated. Second antennal joint longer than broad; frontal keels short, not reaching to the ocelli. Front finely punctured; mesonotum transversely rugosely striolate; the striæ interrupted; mesopleuræ acutely striolate; wings clear hyaline; the nervures pallid, testaceous to fuscous; the radial cellule three times longer than broad.

The of has the head yellowish, with the vertex and front in the middle black, sometimes with the face blackish; the antennæ have the basal half yellow; the legs are of a clearer yellow than in the $q$; the coxæ and femora more or less infuscated.

Length $1-1.5 \mathrm{~mm}$.

One of the smallest species. Reared in June from galls of Andricus noduli. Mayr reports it also from the galls of Cynips lignicola, C. conglomerata, C. amblycera, Andricus gemmx, and Neuroterus albipes; but he suggests that the specimens may actually have issued from the twigs on which these galls were, rather than that they really come from the galls of $A$. noduli. Rare. Clydesdale.

Sweden, Germany, Austria.

\section{Synergus incrassatus.}

Synergus incrassatus, Htg., Germs. Zeits., ii, 707 ; Mayr, Verh. z.-b. Ges. Wien, xxii, 707; Thomson, Opusc. Ent., 793.

Black; the antennæ and legs rufo-testaceous; the coxæ and hind femora more or less black, the anterior sometimes infuscated; wings 
hyaline, the nervures dark rufous; the radial cellule hardly twice longer than broad. Front rugose. Mesonotum with stout, curved, transverse striolations, between which the surface is smooth; mesopleuræ shining, longitudinally striated. Second antennal joint hardly longer than broad; the third about one fourth longer than the fourth. Frontal laminæ narrow, thinning towards the ocelli. Posterior part of petiole broadly rounded from apex to base. Facial keel blunt.

The $\delta$ has the third antennal joint curved, greatly thickened, especially at the apex, and twice the length of the fourth; the second joint broader than long; the head, except the front and vertex in the centre, is rufo-testaceous; the coxæ may be infuscated; the alar nervures are darker.

Length $2.5-3.5 \mathrm{~mm}$.

A distinct species, especially through the thickened antennæ in both sexes and the round petiole.

Common. Found only on root galls; namely, on those of Andricus radicis, A. corticis, and A. Sieboldii.

In size it varies considerably, as it does also in the depth of the sculpture; while in colour I have seen specimens with the head and thorax dull brownish, and the abdomen reddish.

Sweden, Germany, Austria.

\section{Synergus Tschemi. \\ Pl. XII, fig. 6.}

Synergus Tscheki, Mayr, Verh. z.-b. Ges. Wien, xxii, 708.

Black; the antennw and legs rufo-testaceous; the base of the antennæ, the coxæ, the four anterior femora broadly at the base, the posterior almost entirely, and the greater part of the hinder tibiæ fuscous or fuscous-black; the wings hyaline, the nervures fuscous to testaceous. Front and mesonotum coriaceous, alutaceous, the latter sometimes transversely rugulose in the middle. The second antennal joint in the $q$ is a little longer than broad; in the $\delta$ as long as broad; in the $\delta$ the curved and thickened third joint is somewhat longer than the fourth. The radial cellule a little more than twice longer than broad. Apical half of petiole sometimes aciculate, especially in the larger specimens.

Length 2-2.5 $\mathrm{mm}$.

The coloration of the antennæ and legs varies, especially as regards the quantity of the fuscous colour, but the base of the antennæ is never yellow. A specimen reared from the galls of Dryophanta VOL. IV. 
scutellaris has the apex of the petiole punctured above. A series bred from the gall of Dryophanta divisa have the tibiæ and the tarsi infuscated.

Bred in April and May from the galls of Dryophanta divisa, D. scutellaris, Neuroterus numismatis, N. lenticularis, $N$. ostreus, and $N$. fumipennis, all of the second year.

Commonly distributed.

Austria, Germany.

\section{Synergus PALLICORNis.}

Synergus pallicornis, Htg., Germs. Zeits., iii, 709 ;. Mayr, Verh. z.-b. Ges. Wien, xxii, 709; Thomson, Opusc., 797.

- australis, Htg., l. c., iv, 414 .

- flavicornis, Htg., l. c., ii, 198.

Black; the antennæ and legs pale yellow to reddish-yellow ; the four fore femora at base, and the greater part of the hinder, fuscous to blackish; the basal joint of the antennæ, and sometimes the apical joints, infuscated; wings pure hyaline, the nervures pure pale yellow. Second joint of antennæ longer than broad; in $0^{*}$ the third joint is curved, and nearly twice the length of the fourth. Vertex shining, finely rugulose; the frontal laminæ straight, reaching to the hinder ocelli. Mesonotum alutaceous, usually transversely rugulose in the middle, or coriaceous. Radial cellule fully three times longer than broad.

Length 1:5 $2 \mathrm{~mm}$.

The antennæ may be entirely yellow; the hind tibiæ may be infuscated, and the sculpture of the mesonotum shows considerable variety, ranging from alutaceous merely, to transversely striolated.

It comes nearest to $S$. Tscheki, from which it is not always very easily separated. The $\delta$ of Tscheli may be recognised by the third antennal joint not being much longer than the fourth. In the $q$ the antennæ at the base are always blackish. The radial cellule is shorter, being not much more than twice longer than broad. It is a very variable, and difficult to recognise, species.

Reared by Mr. Bignell from Dryophanta scutellaris, 
and by myself from $D$. longiventris and from galled acorns, but these latter examples have the antennæ infuscated. On the Continent Mayr records it from the galls of Cynips Hartigi, C. argentea, C. hungarica, C. tinctoria, C. Kollari, C. lignicola, C. conglomerata, C. glutinosa, C. coriaria, C. polycer a, C. caput-medusæ, C. calicis, Dryophanta folii, D. longiventris, D. divisa, $D$. agama, $D$. disticha, D. cornifex.

Sweden, Germany, Austria.

\section{Synergus aLbipes.}

Synergus albipes, Htg., Germs. Zeits., iii, 349; Mayr, Verh. z.-b. Ges. Wien, xxii, 712 .

- erythrocerus, Htg., 1. c., 349.

Black ; the antennæ and legs clear rufo-testaceous, often pure yellow ; the coxæ, the four anterior femora at the base, the posterior except at base and apex, infuscated or blackish ; the wings hyaline, with lemonyellow nervures. Second antennal joint somewhat longer than broad; the third and fourth joints subequal. Front and mesonotum coriaceous, the latter sometimes finely transversely rugulose. Radial cellule about two and a half times longer than wide. Petiole at apex pyriform.

The $\delta$ has the thickened third joint longer than the fourth.

Length 1-2 $\delta, 1 \cdot 5-2 \mathrm{~mm}$. $q$.

It is difficult to find any very tangible points wherein this species differs clearly from pallicornis. Generally the sculpture is finer and closer, and the fourth antennal joint is proportionately longer; moreover the times of appearance are different, albipes issuing in early summer from the same year's galls, pallicornis from the second year's galls.

I have it from the galls of Spathegaster baccarum, S. tricolor, and Dryophanta divisa. Mayr records it from Biorhiza synaspis, Andricus curvator, Dryophanta agama, and $D$. disticha.

Not uncommon.

Germany, Austria. 


\section{Synergus nervosus.}

\section{Pl. XII, fig. 4.}

Synergus nervosus, Htg., Germs. Zeits., ii, 197 ; Mayr, Verh. z..b. Ges. Wien, xxii, 713, 16 ; Thomson, Opusc., 795, 5.

- $\quad$ tibialis, Htg., Germs. Zeits., ii, 197.

- nigricornis, Htg., l. c., iii, 347 (?).

Black; the antennæ fuscous, or fuscous with a testaceous tinge; the basal joints darker ; legs rufo-testaceous ; the coxæ, the anterior femora at the base, the greater part of the posterior, and the hinder tibiæ fuscous or fuscous-black; wings with the nervures pale fuscous. Front coriaceous; mesonotum finely transversely coriaceous, the keels distinct. Second joint of the antennæ longer somewhat than broad.

The $\delta$ similar in coloration, the second antennal joint broader than long, the third joint curved in the middle and thickened at the apex.

Length $1.5-2 \mathrm{~mm} ., 2-2.5 \mathrm{~mm}$.

Differs from S. vulgaris and tristis in having the antennæ and hinder tibiæ infuscated, and the radial cellule is more sharply pointed at the apex.

I have it from the galls of Andricus autumnalis and A. callidoma, and Mayr reared it from the galls of $A$. collaris.

Sweden, Germany, Austria.

\section{Synergus tristis.}

Synergus tristis, Mayr, Verh. z.-b. Ges. Wien, xxii, 715, 17.

Black ; the legs testaceous, the front femora broadly fusco-brownish at the base, the posterior for the greater part blackish; the tibiæ more or less fuscous, the hinder darker than the anterior, which have usually a testaceous tinge; antennæ fuscous, the 2-3 joints and the apical (especially beneath) testaceous; wings hyaline, with fuscous nervures ; the radial cellule somewhat two and a half times longer than broad at the widest part. Front and mesonotum coriaceous, the apex of the mesonotum finely transversely striolate. Frontal laminæ moderately distinct. Second antennal joint longer than broad.

The $\delta$ has the antennæ lighter coloured than in the $q$, the third joint thickened, about one-fourth longer than the fourth.

Length $1.5-1.8$, o $1 \cdot 5-2.5 \mathrm{~mm}$.

It is not easy to hit upon any very satisfactory characters whereby to separate this species from S. Tscheki; generally the latter may be known by the antennæ being rufo-testaceous, and the tibiæ not in- 
fuscated. Still I have reared from Dryophanta divisa galls examples of Tscheki which have the antennæ and tibiæ infuscated. A further noteworthy difference lies in Tscheki issuing from the galls in the autumn, while tristis emerges in the spring.

Mr. Bignell and myself have bred it from Neuroterus ostreus in the spring, and Mayr from Andricus urnæformis.

Not common, seemingly.

Austria.

\section{Synergus vulgaris.}

Synergus vulgaris, Htg., Germs. Zeits., ii, 198; Mayr, Verh. z.-b. Ges. Wien, xxii, 715 .

Black; the antennæ and legs reddish-testaceous, the first joint of the antennæ more or less infuscated; the apical joints more or less fuscous; the coxæ, the base of the four front femora, and the greater part of the posterior femora blackish; alar nervures pallid fuscous. Vertex and front coarsely punctured; frontal laminæ clearly defined; facial keel moderately distinct. Mesonotum coarsely transversely rugulose. Second antennal joint a little longer than broad.

The $\delta$ has the head rufo-testaceous, except the front, vertex, and occiput; the antennæ are entirely rufo-testaceous, with sometimes the basal joint more or less infuscated; the third joint acutely bent in the centre; the legs are not so much infuscated.

Length $2-3 \mathrm{~mm}$.

A species not difficult to recognise. I have it from the galls of Andricus callidoma. On the Continent it is known from the galls of Cynips tinctoria, C. lignicola, C. glutinosa, C. caput-medusæ, C. calicis, Andricus gemmæ, A. solitaria, A. Clementinæ, A. urnæformis, $A$. glandium. It issues in March in the house.

Clydesdale.

Germany, Austria.

\section{Synergus fadialis.} Pl. XII, fig. 1.

Synergus facialis, Htg., Germs. Zeits., ii, 199; Mayr, Verh. z.-b. Ges. Wien, xxii, 717, 19.

- bispinus, Htg., l. c., iii, 349. 
Diplolepis gallæ-pomiformis, Fonsc., Ann. Sc. Nat., xxvi, 1832, 195, partim.

Black; the head except the front above, vertex, the antennæ, and legs rufo-testaceous; the hinder coxæ more or less black; the abdomen fuscous-piceous or obscure red or testaceous, never quite black; wings hyaline, the nervures pallid rufo-yellow; the radial cellule longer than broad, acute at the apex; the basal abscissa of the radius curved, the apical straight. Punctation on head and thorax moderately coarse, transverse on the mesonotum; mesopleuræ longitudinally striolated; frontal laminæ distinct, not reaching to the hind ocelli; facial keel indistinct.

Length $1.5-2.5 \mathrm{~mm}$.

One of the commonest species. Common in the galls of Biorhiza terminalis; also in those of Andricus curvator, A. albopunctata, A. solitaria, A. ramuli, Spathegaster baccarum, S. tricolor, Trigonaspis megaptera, and on the Continent in those of Cynips glutinosa. It appears in July.

Sweden, Germany, Austria.

\section{Synergus Radiatus.}

Synergus raidiatus, Mayr, Verh. z.-b. Ges. Wien, xxii, 718, 20.

Black; the antennæ and legs reddish-testaceous; the coxæ for the greater part blackish; vertex and front finely, in some examples transversely, rugulose; mesonotum strongly coriaceous or rugulose, sometimes transversely. Frontal laminæ distinct.

Length $1 \cdot 5-2.5 \mathrm{~mm}$.

Closely allied to S. facialis, differing in having the head black except at the oral region, the sculpture much finer, and the coxæ are for the greater part black.

Common in the galls of Spathegaster baccarum; also in those of Andricus albopunctata, A. curvator, $A$. solitaria, and $A$. ramuli. Mr. Bignell has bred it from A. glandulæ. Widely distributed and common. Appears in June.

Germany, Austria. 


\section{Synergus thaumadera.}

Cynips thaumacera, Dal., Anal. Ent., 1823, 96.

Synergus Klugii, Htg., Germs. Zeits., ii, 199.

- luteus, Htg., Germs. Zeits., ii, 199.

- $\quad$ carinatus, Htg., Germs. Zeits., iii, 348 (?).

- thaumacera, Mayr, Verh. z.-b. Ges. Wien, xxii, 719, 21 ; Thomson, Opusc., 796, 6.

Black ; the antennæ, head (except the vertex), and legs bright rufotestaceous ; alar nervures fuscous; antennæ thickened. The second antennal joint is about as long as broad; the third joint considerably longer than the fourth. Front punctured or finely coriaceous; mesonotum transversely rugulose. Frontal laminæ usually indistinct. Mesopleuræ aciculate.

The $\delta$ has the second antennal joint usually thicker than long; the third greatly elongated and swollen, especially at the apex.

Length 1-2, $\delta 1-3 \mathrm{~mm}$.

A well-marked species from the thickened antennæ. The coloration of the head, particularly in the $q$, is very variable, varying as it does from almost entirely black to almost entirely rufo-testaceous, but in the latter case the vertex is usually black; the antennæ also may be infuscated at the base and the apex; the thorax and abdomen, too, may be more or less rufous.

I have only reared it from the galls of Biorhiza megapter $a$ and renum, but it is also known from the galls of Cynips cerricola, And. singularis, A. cydoniæ, Spathegaster baccarum, S. tricolor, S. nervosus, and S. glandiformis.

Common.

Sweden, Germany, Austria.

\section{Gemus Diastrophus.}

Diastrophus, Hartig, Germs. Zeits., ii, 186.

Antennæ, o $13-14$-jointed, $\delta^{\wedge} 14$-jointed. Cheeks without furrows, more than balf as long as the eyes. The face on each side finely striolate. Mesonotum smooth, shining, glabrous ; the parapsidal furrows complete. Scutellum separated from the mesonotum by a keel; at its base are 
two large fovex, distinctly separated from one another or not. Median segment with two parallel keels. Abdomen sessile, globular, not compressed, the second segment with the o occupying half of the total length, and having the ventral spine as long as thick. Wings ciliated, the radial cellule moderate or short, broad at the base, open in front; the areolet absent or present, placed near its base. Claws bifid.

The antennæ are stout; the joints are all clearly separated, the third being the longest in both sexes, and in the $\delta$ is incised; the others from the fifth being of equal length and thickness; the apical being somewhat thinner, especially in the $\delta$.

The species of Diastrophus are black, with the abdomen sometimes brownish, and the legs yellowish. The genus comes nearest to Aulax, which is readily known from it by the thorax being aciculate or alutaceous, not shining and polished.

There are three European species,-two, rubi and Mayri, forming galls on Rubus; the other, $D$. aphidivorus, being parasitic on an Aphis; and four North American species are known.

1 (2) Scutellar foveæ distinctly separated; the scutellum not furrowed down the centre.

$R u b i$.

2 (1) Scutellar foveæ confluent; scutellum fur'rowed down the centre. Aphidivorus.

\section{Diastrophus RUBi.}

Pl. IX, fig. 2, gall ; Pl. XIII, fig. 6, .

Diastrophus rubi, Htg., Germs. Zeits., ii, 194 ; iv, 410 ; Marshall, E.M.M., iv, 223 ; Tasch., Hym. Deut., 123 ; Mayr, Cyn. Gallen, 14; Eur. Cyn., 12.

Andricus Hartigi, Marshall, E. M. M., iv, 101.

For gall and larva see Réaumur, Mém., t. 3, pl. xxxvi, figs. 15 ; and Malpighi, Opera, ii, tab. xvii, fig. 61 .

Black; legs reddish-yellow, the coxæ at the base fuscous; antennæ, o 13-, of 14:-jointed, fuscous-black ; the four or five basal joints more or less reddish; wings hyaline, the nervures blackish or brownish ; the basal abscissa of radius curved slightly, $\delta$ and $q$. The $\delta$ has the third joint of the antennæ curved.

Length $2-2.5 \mathrm{~mm}$.

The face and sides of the thorax are aciculate; the tegulæ vary from black to red; the oral region is 
usually reddish; generally the abdomen is black, but it may be piceous; and the ventral surface is often reddish; the thorax also may have fulvous or reddish blotches ; the areolet may be obsolete or semi-obsolete.

The nearest allied species is D. Mayri, Reinhard, which agrees with it very closely, but may be best known by the antennæ being 14-jointed in both sexes (sometimes, however, 15-jointed in $\delta$ according to Reinhard); the thorax and abdomen are more slenderly built, the basal abscissa of the radius is thicker and geniculately curved, and the areolet is never defined. D. Mayri forms galls on Potentilla argentea.

Gall.-Forms irregular, spindle-shaped swellings on the stems of Rubus fruticosus, $R$. cæsius, and $R$. idæus; smooth, or beset with small elevations caused by the larval chambers; or more or less of it may be thickly covered with small spines, and may even bear large spines. They are green when young; get brownish when old. In length they range from two to eight inches. They contain numerous oval larval cells, embedded in the medullary sheath; the cells have a distinct wall of a yellower colour than the pith, and have an average diameter of about $2 \frac{1}{2} \mathrm{~mm}$.; and are, as a rule, situated quite close to the outer rim or back.

Parasites.-Torymus cynipoides, Gir. (this is probably a MS. name), T. macropterus, T. rubi, Schenck, Eupelmus annulicornis, Encyrtus ruborum, * Gir., Decatoma quercicola, Foer., Eurytoma quercicola, Foer., E. diastrophi, Gir., E. abrotani, Pteromalus incrassatus, Rtz. (Brischke).

Local, but with a wide range. Sweden, Germany, Austria, France.

* This is on the authority of Girand (Ann. Soc. Ent. Fc., 1877, p. 423), but there is probably a mistake here. 


\title{
2. Diastrophus aphidivorus.
}

\author{
Pl. XIII, fig. 7, ㅇ . \\ Diastrophus (?) aphidivorus, Cameron, Proc. Lit. and Phil. \\ Soc. Trans., Manr., ii (4i), 67.
}

Black; the antennæ testaceous ; the legs rufo-testaceous; the tips of the tarsi black; wings almost hyaline, the nervures fuscous, thick. Antennæ stout, a little longer than the hody ; the third joint sinuate, a little longer than the fourth. Head large, a little wider than the thorax, shining, impunctate. Prothorax large, finely rugose, semiperpendicular in the middle. Mesonotum shining, obscurely striated at the base; the parapsidal furrows distinct at the base. Scutellum rugosely punctured, depressed in the centre; the basal foveæ large, wider than long, curved, united. Metapleuræ rugosely punctured. Abdomen shining; the second and third segments subequal, apical ventral segment bluntly ploughshare-shaped, not projecting beyond the apex. Hind tibiæ curved; the metatarsus twice the length of the second joint; claws apparently simple; wings ample; the radial cellule open at base and apex and in front; narrow, elongate; the third abscissa of the radius curved; cubitus nearly complete. $\delta$.

Length nearly $1 \frac{3}{4} \mathrm{~mm}$.

Differs from Diastrophus proper in the claws being simple, in the scutellar fover being confluent, and there is a depression in the centre of the scutellum.

Bred by Rev. T. A. Marshall at Barnstaple from the Aphis of the nettle.

\section{Genus ANDRIOUs.}

Andricus, Hartig, Germs. Zeits., ii, 185.

Callirhytis, Foerster, Verh. z.-b. Ges. Wien, 1869, 335. Aphilothrix, Foerster, 1. c., 336.

Antennæ, o 12-15-jointed, $\delta$ 14-16-jointed, the third joint longer than the fourth; without hairs. Cheeks rarely with a furrow, either as long as or shorter than half the length of the eyes. Head with the agamic forms always dilated behind the eyes, with the female sexual forms often, with the $\delta$ seldom dilated. Parapsidal furrows complete, sharp. Scutellar foveæ sharply separated. The median segment with the keels straight and parallel, or curved as in A. ostreus. Abdomen compressed, the segments distinctly separated, the ventral horn projecting, moderately long. Wings with the radial cellule open, elongate, the areolet generally present. The claws bifid, except in Callirhytis, which has them simple; Callirhytis being further distinguished by having the mesonotum transversely rugulose. 
The genus contains some undoubted agamic species. The sexual forms have, with the exception of $A$. inflator and $A$. curvator, the antennæ 13-jointed; the lastmentioned having them 14-jointed. They are further to be known from most of the agamic species by having the mesonotum, especially posteriorly, very shining and glabrous, at the best having only the centre of the mesonotum slightly pilose. With two exceptions (amenti and ramuli) they are black, with the legs more or less dark, light, or citron yellow. As usual, the spring forms are much smaller than the agamic. These have the antennæ 13-15-jointed; few, however, of our species having them 13-, and none 15-jointed. Some of them, e.g. glandulæ, albopunctata, collaris, have the mesonotum glabrous and shining as in the sexual forms. Very few are entirely black, and many of them are very variable in coloration. In both forms the head may be widened behind the eyes.

Generally this and the following genera (the oakfrequenting species) are to be known from the preceding by the cheeks being at least half as long as the eyes, while the radial cellule is much narrower and longer.

It is worthy of remark that at Kew Gardens two species are found on the Turkey oak (Quercus cerris), these species neither here nor on the Continent being known to frequent $Q$. robur. As $Q$. cerris is an imported tree, not native, it may be presumed that the gall-flies have been introduced in some way also.

A. Claws simple; mesonotum transversely rugulose (Species 1). 


\section{Andricus glandium.}

Pl. VIII, fig. 2.

Andricus glandium, Giraud, Verh. z.-b. Ges. Wien, 1859, 355; Mayr, Eichengallen, .66, fig. 92 ; Eur. Cyn., 12.

- rufescens, Mayr, 1. c., 13.

Agamic Form.-Black; the basal five or six joints of the antennæ, the orbits almost entirely, the oral region, the knees, the fore-tibia and the tarsi, ferruginous. Often the abdomen is more or less brownish towards the apex. Wings hyaline. Bare: the head dilated behind the eyes; cheeks with a sharp keel; the face aciculate; the mesonotum transversely rugulose; scutellum coarsely reticulated or transversely rugulose behind. Parapsidal furrows usually complete.

Length $3 \mathrm{~mm}$.

The quantity of ferruginous colour on the head varies considerably, and some examples are almost devoid of it.

The larvæ live in the acorns of Quercus cerris, in irregular cells in the inside; the cells being variable as regards the number in an acorn, and as to their form. The acorns are seldom distorted or bent to any appreciable extent by the larvæ. The cells are placed all round the acorn, are white, and surrounded by a thickened wall ; in length and breadth they vary, some being 3 and others only $2 \mathrm{~mm}$. in length.

They are found in the autumn. The general experience seems to be that they take from three to four years to come to maturity; while numbers of them appear, even when kept outside, never to change at all.

No parasites have been bred from the galls, and the only inquiline is Synergus vulgaris.

Sexual Form.-This I have not seen, nor am I aware that the gall has been described. Mayr's description is-

o reddish-yellow, the thorax without black, and with reddish-yellow metanotum; the abdomen at the apex above blackish-brown. Parapsidal furrows complete; the scutellum coarsely rugulose; the wings clear hyaline, shortly ciliated on the hinder edge of the middle. Length $2 \cdot 1 \mathrm{~mm}$.

$0^{\pi}$ reddish-yellow, the vertex between the ocelli infuscated; the abdomen behind more or less brownish. Antennæ 16-jointed (the $f$ 
antennæ unknown to Mayr), the joints from the fifth to the terminal diminishing but slightly in length; mesonotum and scutellum as with the o. Wings ciliated.

Length $2 \mathrm{~mm}$.

In this country it is only known from Kew Gardens, where it is found only on Quercus cerris. On the Continent it is found in Austria and France.

The only other species of Callirhytis is Andricus Hartigi, Foer., the gall of which has not been described.

\section{B. Claws bifid.}

1. Keels on median segment bulging outwardly, not straight and parallel.

\section{ANDRIOUS OSTREUS.}

Pl. VII, fig. 3, gall ; Pl. XIII, fig. 9, + .

Neuroterus ostreus, Giraud, Verh. z.-b. Ges. Wien, 1859, 350 ; Adler, Zeits. wiss. Zool., xxxv, 199, pl. x, fig. 19; Lichten. Oyn., 64, pl. x, fig. 19 ; Mayr, Eichengallen, 47, pl. vi, fig. 67 ; Schenck, Nass. Cyn., 68, 72, and 105.

Andricus ostreus, Mayr, Eur. Oyn., 14.

Dark brownish-black, the head and thorax streaked occasionally with dark rufous; the legs rufous-yellow, the base brownish; sometimes the rufous tinge is absent. Antennæ longish, thin, very slightly and gradually thickened towards the apex. Head and mesonotum finely shagreened; the scutellum rugose. Wings longish, very slightly fulvous tinted, the apex with longish ciliæ. Thorax finely pilose, more thickly on the scutellum, shining; abdomen shining, glabrous. Ventral sheath triangular, much longer than broad.

Length 2-21 $\mathrm{mm}$.

Gall.-Found in August and September on (as a rule) the midrib on the under side of the leaf ; and at the base is situated between two brownish membranes as long, or even longer than, the length of the gall. The gall is from 1 to $2 \mathrm{~mm}$. in length, roundish or ovoid or oval; whitish or greenish with pink spots when young, becoming whitish-yellow when old; smooth, shining, and bare. Often the pink or red- 
dish spots are absent. The basal membranes remain attached to the midrib, but the galls fall to the earth before the larvæ are grown.

The galls become ripe in October, the flies issuing from them in that month except on rare occasions, when they remain undeveloped until the following year. As a rule the galls are attached to the leaves about three weeks, their resting-places on the midrib being indicated by the basal membranes.

The species is readily known by the bulging curved keels on the median segment. The antennæ and the wings too are longer than usual, and the former are thinner, shaped more like those of Neuroterus than of typical Andricus. Synergus Tscheki and S. tristis are the inquilines. Giraud records Pteromalus bisignatus, Gir., as a parasite. Eurytoma rosæ is another. Adler observed ostreus lay its eggs in the leaf-buds in October, but it also appears in March.

2. Keels on the median segment straight and parallel.

\section{ANDRICUS FEOUNDATRIX.}

Pl. III, figs. 3 and 3 a (fecundatrix, pilosus), gall ; Pl. XIV, figs. 1 and 1 a (fecundatrix, pilosus).

Cynips gemmæ, Lin. Fn. Sv., 1525.

- fecundatrix, Htg., Germs. Zeits., iii, 325.

- gemmæ, Schenck, Nass. Cyn., 54, 57, 113, and 134.

Aphilothrix gemme, Mayr, Eichengallen, 23, pl. iii, fig. 28; Fitch, Essex Field Club, ii, 136.

- fecundatrix, Adler, Zeits. wiss. Zool., xxxv, pl. x, fig. 10; Licht. Oyn., 37, pl. i, fig. 10. Andricus fecundatrix, Mayr, Europ. Cyn., 23.

- pilosus, Adler, Zeits. wiss. Zool., xxxv, 180, pl. x, fig. $10 a$; Licht., Cyn., 40, pl. i, fig. $10 a$; Mayr, Europ. Cyn., 19.

Agamic Form.-Black or fuscous-black; the abdomen with a brownish tint, reddish at base and apex, paler at the sides; the legs brownishblack; the knees and anterior legs in front brownish-red; the fore-tibiæ strongly and thickly covered with erect hairs; the middle of the vertex 
and thorax rugose; head and thorax with a sericeous pubescence; there are two broad, glabrous, smooth longitudinal stripes on the outer half of the parapsidal furrows.

Length $4-4.5 \mathrm{~mm}$.

Comes nearest to $A$. globuli, from which it may be known by the vertex being much more strongly punctured.

The gall is found on young oaks as a rule, and chiefly on the pedunculated form. It lies enveloped in the leaf-bud, the scales of which become enormously developed, so as to give the gall the appearance of a miniature artichoke, the size of which may reach three quarters of an inch. At the bottom of this imbricated mass is found the gall proper, which is green at first, becoming brownish towards maturity; in shape like a pear, the narrow end being at the base : it is hard and woody, and about $10 \mathrm{~mm}$. in length. Fully developed examples show a small roundish, more or less shining impression, with a small conical mass in the centre. At first it is attached to the bud, but when mature loosens itself and falls to the earth. In certain cases the fly may issue in the following spring, but not unfrequently the larva may remain unchanged for three or four years. The number of abortive galls seems to be very large, this, apparently, not being caused by inquilines. Some larvæ appear never to change, but die in the galls.

The inquilines are Synergus melanopus, S. apicalis (but Mayr suggests that this may have come from the galls of Andricus 3-lineatus), S. vulgaris, and on the Continent S. evanescens, Mayr.

There are few parasites, the only species recorded being Syntomaspis caudatus (Brischke), Torymus regius, Nees (inconstans, Walker); Megastigmus dorsalis, Fab.; Eurytoma signata, Nees ; E. rosæ, Mesopolobus fasciiventris, West.; Entedon leptoneurus, and Olina trilineata.

It is worthy of remark that the moth Carpocapsa juliana is a common inhabitant of the galls.

There can be no doubt that Linné describes the 
gall of this species under the name of gemmæ; but it is not equally clear that he has described the insect. His short description-" (Grisea seu testacea, oculi fusci, antennæ subfuscæ, longitudine corporis"-may refer to a Synergus.

Sexual Form.-Black, shining; the scape of the antennæ brown; joints $2-5$ yellowish-testaceous, the rest fuscous; the legs yellowishtestaceous, the anterior femora at the base, the posterior except at the base and apex, infuscated; the coxæ black at the base. Face aciculate, the pronotum finely punctured, the scutellum rugose. Wings hyaline, the nervures fuscous-black. Abdomen dull black, the ventral surface brownish. Head not dilated behind, and frequently castaneous or brownish.

The $\delta$ has the antennæ darker, the basal joints black; joints $2-3$ dark yellow ; the rest brownish; paler beneath ; the apex of the femora, tibiæ, and tarsi pallid yellow. Scutellum shagreened; the fore-coxæ at the base are brownish, the middle and hinder are for the greater part black; the third antennal joint only slightly curved, narrowed at the base.

Length $1.5 \mathrm{~mm}$.

Gall.-Found in the $\sigma^{*}$ catkins in May. Length $2 \mathrm{~mm}$., oval, narrowed a little towards the apex, sometimes as broad there as at the base; dull green when young, brown when old, covered thickly with long white hair; the surface rough. The gall is usually found singly, but three or more may be occasionally be placed close together. (See $A$. amenti.)

Commonly distributed in Britain.

Continental distribution : Sweden, Germany, Austria, Switzerland, France.

\section{ANdricus gLObULi.}

Pl. IV, figs. 1 (globuli) and 1 a (inflator); galls.

Cynips globuli, Htg., Germs. Zeits., iii, 336 ; Schenck, Nass. Cyn., 54, 59, and 114; Kirchner, Cat., 23.

Aphilothrix globuli, Mayr, Eichengallen, 24, pl. iv, fig. 30 ; Adler, Zeits. wiss. Zool., xxxv, 174, pl. x, fig. 8; Licht. Cyn., 32, pl. i, fig. 8; Fitch, Essex Field Club, ii, 136, fig. 25. Andricus globuli, Mayr, Europ. Cyn., 23.

- inflator, Htg., Germs. Zeits., ii, 191 ; Schenck, Nass. Cyn., 74, 75, 76, and 119; Mayr, Eichengallen, 29, pl. iv, figs. 38 and $38 a$; Europ. 
Cyn., 20; Adler, Zeits. wiss. Zool., xxxv, 176 , pl. x, fig. $8 a$; Licht. Cyn., 34 , pl. i, Cynips inflator, Thoms., Opusc., 787. fig. $8 a$; Kirchner, Cat., 26.

Agamic Form.-Black; the abdomen brownish, more or less red at the base and apex; legs brownish-red, the coxæ and four posterior tibiæ infuscated ; antennæ brownish; mesonotum punctured, but not closely; the vertex only punctured slightly; there is one smooth and glabrous longitudinal line along the parapsidal furrows; the fore-tibiæ with stiff, erect, longish hairs. Agamic + .

Length $4 \mathrm{~mm}$.

Gall.-Found, as a rule, in the terminal leaf-bud, enveloped by the scales so that only the apex is visible. Conical, $3-5 \mathrm{~mm}$. in length, green when young, pale when old; the apex terminating in a conical point or wart, usually of a more or less reddish or yellowish colour. When young the surface is soft and sappy, which surface, on drying, forms irregular reticulations or wrinkles. The inner surface next to this sappy matter is also reticulated.

This gall is easily known from those of autumnalis and collaris by the shape being much shorter, more globular, broader, and by the reticulated surface ; it is also greener, and projects more out of the bud.

I have not succeeded in rearing this insect myself. According to Adler, although the larva reaches its full development in October, it does not change then, nor even in the following spring, but remains unchanged till the autumn, coming out of the gall in the fly state in the April following, thus taking two years to reach full maturity. Adler says that only one egg is placed in each bud; and the laying of this one egg occupies the fly twenty minutes.

The only inquilines recorded are Neuroterus parasiticus, Htg.; Synergus nervosus, Htg.; S. vulgaris, S. ruficornis, Htg.; and the only known parasites are Siphonura chalybea, Rtz. (cf. Schlectendal, Stett. Ent. Zeit., 1870, 343) ; Torymus regius, Fab. ; Megastigmus dorsalis (Giraud); Eurytoma rosæ.

Sexual Form.-Black; the abdomen reddish beneath; the base of the antennæ and legs reddish.yellow, the hind coxæ black at the base, the VOL. IV. 
hind tibiæ infuscated. Moderately shining, the mesonotum shagreened throughout; mesopleurm more or less striolate, the twelfth and thirteenth antennal joints clearly longer than broad; the apical joints scarcely thickened.

The $\delta$ is similar in coloration.

Length $2 \mathrm{~mm}$.

May be known from curvator by the less shining mesonotum, which is shagreened uniformly all over; by the less thickened antennæ (towards the apex), of which the joints are all longer than broad; and by the striated mesopleuræ.

The gall-fly emerges in June.

Forms a swelling on the terminal twigs of oaks $10-15 \mathrm{~mm}$. in length, of somewhat irregular form, smooth and green when young, becoming black or dark brown when old, the surface then becoming irregular. The internal cavity is longish, narrow, of nearly equal width, and has the small, loose, ovoid inner gall at its bottom, the cavity not being much wider than the inner gall, and at the top at least is lined with a membrane. The gall originates in a terminal bud, and when the fly quits the gall in June the swelling still continues to grow, and may become surrounded with leaves or twigs.

Curvator, it may be noted, forms terminal swellings like those of inflator; but these are seldom so elongated, and the internal cavity is larger, and more particularly wider.

The parasites bred from this species are Megastigmus dorsalis, Torymus auratus, Fonsc.; Decatoma Neesi, Foer. (Giraud); Pteromalus dissectus, Walk. (Giraud); P. Erichsoni, Rtz. (Giraud).

The only inquiline is Sapholytus connatus, Htg. (Mayr).

Rare and local.

Continental : Sweden, Switzerland, Germany, Austria. 


\section{ANDRIOUS RADIOIS.}

Pl. IV, figs. 3 (radicis) and 3 a (3-lineatus), galls; Pl. XIV, figs. 2 (radicis) and $2 a$ (3-lineatus).

Cynips radicis, Fab., E. S. Suppl., 213, 10 ; Syst. Piez., 146, 11 ; Htg., Ger'ms. Zeits., ii, 207; iv, 402 ; Schenck, Nass. Cyn., 56, 62, and 121 ; Mar'shall, E. M. M., iv, 7 ; Kaltenbach, Pfl., 667.

Aphilothrix radicis, Mayr, Eichengallen, 6, pl. i, fig. 1 ; Adler, Zeits. f. wiss. Zool., $\operatorname{xxxv,167,~pl.~x,~}$ fig. 5; Licht. Cyn., 22, pl. i, fig. 5; Fitch, Essex Field Club, ii, 132, fig. 17. Andricus trilineatus, Htg., Germs. Zeits., ii, 191; Mayr, Europ. Cyn., 18; Marshall, E. M. M., iv, 101.

- noduli, Htg., Germs. Zeits., ii, 191; Schenck, Nass. Cyn., 74, 75, 78, 111, and 119; Mayr, Eichengallen, ii, pl. i, fig. 9; Adler, Zeit. f. wiss. Zool., xxxv, 169, pl. x, fig. $5 \alpha$; Licht. Cyn., 24, pl. i, fig. $5 a$; Marshall, E. M. M., iv, 102 ; Kaltenbach, Pfl., 667.

- radicis, Mayr, Europ. Cyn., 26.

Agamic Form.-Brownish-red on the head and thorax, the abdomen without the brownish tinge; the occiput, three brownish broad stripes on the mesonotum, the mesonotum more or less at the base, the greater part of the mesopleuræ behind, the propleuræ in part, the base of the coxæ, the centre of the median segment, and a large roundish spot on either side of the top of the second abdominal segment, black; the hinder tibiæ more or less, and the claws, infuscated. Antennæ with the basal four or five joints brownish-red, the others more or less infuscated, usually paler beneath. Head and thorax shagreened, densely covered with a silky pubescence; abdomen shining, the second segment with a large part of its lower and hinder border covered thickly with white hair; the third segment is finely aciculate. Wings hyaline; from the areolet run two (often very indistinct) narrow, faint, diverging streaks to near the edge of the wing.

Length $4-6 \mathrm{~mm}$.

Gall polythalamous, sometimes composed of hundreds of cells (Westwood relates having reared 1100 specimens from a gall 5 inches long by $1 \frac{1}{4}$ inches broad-cf. Int., ii, p. 128), and found at the roots of oaks or a few feet up the trunk. At first they are whitish, sometimes marked with pink or red, smooth and soft; becoming with age quite hard and woody, and the surface frequently rough and irregular. The single cells are irregular, usually roundish or oval. 
The form of the gall is very irregular; it may be pear-shaped, round, or oval; and on the trunk especially it may take the form of a mere swelling. As has already been pointed out (p. 2), it seems very possible that more than one individual may unite to form such large galls as those mentioned above.

The only inquiline is Synergus incrassatus, Htg. Of parasites there are Torymus nobilis, T. erucarum (Cynipidis, Wlk.), T. amoenus, T. radicis, Gir. (Giraud); Pteromalus quercinus, Gir. (Giraud); Tetrastichus quercûs, Wlk. (Giraud); Eurytoma rosæ.

The first development of the gall takes place in September; but the growth which then takes place is very slight, and stops during the winter, until, with the spring and the renewed life of the tree engendered by the heat, the gall recommences growth and soon reaches its full development.

I have found the flies out as early as February, and alive in the galls in December; but these examples were, no doubt, specimens whose development had taken a year longer.

Sexual Form.-Brownish-red; the head and thorax marked with black, or for the greater part black; abdomen also more or less black: the legs pale testaceous; wings hyaline. Head dilated behind the eyes. Vertex and mesonotum finely shagreened; scutellum finely rugose.

The $\delta$ is more shining, and has the head and thorax black, the legs of a clearer obscure yellow, the hinder femora and tibire often infuscated; the antennæ testaceous at the base, the rest more or less infuscated.

Length 1-3 $\mathrm{mm}$.

A very variable species, not only in size, but in coloration and punctation. The variations may be best described by giving a description of the large and small forms.

Large Form (2 mm.).-Brownish-red; three broad lines on the mesonotum; scutellar fover, and apex of abdomen above, black ; the legs light brownish-yellow; the hind femora and tibiæ infuscated; antennæ with the basal joints pale brown, the others slightly infus- 
cated. Head and thorax strongly aciculate, the scutellum distinctly rugulose; head and thorax with the pubescence thick and longish; the dilatation behind the eyes distinct ( $=A$. trilineatus).

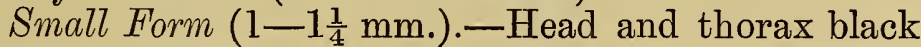
or fuscous-black; the sutures of the mesonotum sometimes yellowish-red; the abdomen reddish-yellow, blackened at the apex above; the legs pale yellowred; the base of the coxæ blackish; antennæ yellowish-red at the base, the rest fuscous; punctation on head and thorax very fine, sometimes obsolete; the dilatation behind eyes indistinctly developed.

Between the two extremes there are numerous intermediate variations.

Gall.-Found in twigs, or more rarely on the petioles of the leaves, usually gregariously. They are oval or ovoid, about $2 \mathrm{~mm}$. in length, embedded in the wood or in the bark, or partly in both. The galls have no very distinctly lined membrane. When they occur in numbers, the petiole, more particularly on twigs, becomes irregularly distorted, with raised points where the galls are. When the insects escape they leave a round exit hole by means of which the presence of the galls is easily noticed. The flies escape early in the autumn.

The sexual has fewer parasites and inquilines than the larger agamic form. They are Ceroptres arator, Sapholytus connatus, Htg.; and Synergus apicalis, and according to Kaltenbach, Synergus vulgaris. The parasites are Megastigmus dorsalis and Pteromalus quercinus, Gir. (Giraud). Very widely distributed in Britain.

Continental distribution: Sweden, Switzerland, Germany, Austria, France. 


\section{Andricus Sieboidit.}

Pl. V, fig.. 4 (Sieboldii) and $4 a$ (testaceipes), galls; Pl. XIV, figs. 3 (Sieboldii) and 3 a (testaceipes).

Cynips Sieboldii, Htg., Germs. Zeits., iv, 406.

- corticalis, Schenck, Nass. Cyn., 63.

Aphilothrix Sieboldii, Mayr, Eichengallen, 8, pl. i, fig. 5; Adler, Zeits. f. wiss. Zool., xxxv, 171, pl. x, fig. 6 ; Licht. Cyn., 27, pl. i, fig. 6 ; Fitch, Essex Field Club, 133, fig. 19.

Andricus testaceipes, Htg., Germs. Zeits., ii, 191; Adler, 1. c., 172 ; pl. x, fig. $6 a$; Mayr, Europ. Cyn., 18 and 28; Licht. Cyn., 28, pl. ii, fig. $6 a$; Kaltenbach, Pfl., 666.

- Sieboldii, Mayr, Europ. Cyn., 25.

Rufous or brownish-red, sometimes the sutures of thorax and base of scutellum more or less blackish; median segment blackish; legs uniformly brownish-red, sometimes with the hind tibiæ infuscated. Scutellum finely punctured. Second abdominal segment impunctate, unicolorous, the hair narrow only on the anterior portion of the segment; the third segment finely punctured. Wings hyaline; in the third cubital cellule is a single indistinct, faint, narrow streak. Antennæ infuscated, paler at the base. Agamic $q$.

Length $3 \cdot 5-4.5 \mathrm{~mm}$.

This species comes near to radicis, but is smaller than it, has the body almost unicolorous, less pilose, the second segment is only haired at the apex, and wants the two marks found in radicis, the faint line in third cubital cellule does not diverge, and the thorax is less pilose.

Gall.-Found on small branches of young oaks, especially near the earth, which frequently covers them. They are gregarious, conical, dilated at the base, woody and hard. When young the colour on the upper region is reddish or pink, and covered with a bloom and a gummy secretion. When old the surface becomes longitudinally striolated, the exterior bloom disappearing. The larval chamber occupies the lower dilated part, which is sunk deeply in the branch. The height of the gall is from 6 to $8 \mathrm{~mm}$., whereof about the third will be sunk in the branch. 
Sometimes these galls occur so thickly on a branch as to kill it. The fact of ants feeding on the exudation has been already mentioned (p. 16).

The inquiline is the root and bark-frequenting Synergus incrassatus, and the parasites Torymus nobilis and Eurytoma rosæ. Adler says that the galls of Sieboldii are " in a high degree exposed to the attacks of various parasites of the genera Torymus and Synergus," but no names are given. Mayr bred Olinx trilineata and Eurytoma rosæ from them.

Sexual Form.-Black, shining; legs yellow, abdomen for the greater part reddish-yellow, the apical half or so blackish above, the ventral surface paler, hypopygium brownish. Antennæ dark brown, the basal three or four joints pale yellow. Hind coxæ brownish at the base; tegulæ and a spot (sometimes absent) at the base of the mesonotum brownish-yellow. Scutellum opaque, coarsely aciculate or finely rugulose. Face aciculate. Mesonotum more or less at the base pilose. Head elongate, distinctly dilated behind the eyes.

The $\delta$ almost agrees with the o in colouration; the third antennal joint is slightly dilated and curved.

Length 1.5-2 $\mathrm{mm}$.

Agrees with trilineatus in having the head widened behind the eyes, but differs in the black head and thorax.

Gall.-Forms an elongated swelling on the midrib towards the centre of the leaf, in the petiole, or even on the very young twigs. There is only one cell, but the swelling extends considerably beyond the part where the larva lives ; it is from $1 \frac{1}{2}$ to $2 \mathrm{~mm}$. in length, and is surrounded internally by a fine white cellular substance. In colour it is green, differing but slightly from the colour of the leaf.

Synergus apicalis and Ceroptres arator are supposed to be reared from the galls of testaceipes, but they really may have been from those of noduli, the petiole galls of which may have been mistaken for those of testaceipes. The parasite is Megastigmus dorsalis.

Rare and local in Scotland and England.

Continental distribution: Switzerland, Germany, Austria. 


\section{ANDRICUs CORTICIS.}

Pl. IV, figs. 4 (corticis) and 4 a (gemmatus) ; Pl. XVII, fig. 3.

Cynips corticis, Htg., Germs. Zeits., ii, 190 ; Schenck, Nass. Cyn., 55, 59, 121, and 135; Kaltenbach, Pfl., 667; Kirchner, Cat., 23; Thoms., Opusc., 783.

Aphilothrix corticis, Mayr, Eichengallen, 7, pl. i, fig. 3 ; Adler, Zeits. wiss. Zool., xxxv, 173, pl. x, fig. 7; Licht. Cyn., 30, pl, i, fig. 7.

Andricus corticis, Mayr, Europ. Cyn., 25.

- gemmatus, Adler, l. c., 174, pl. x, fig. $7 a$; Licht. Cyn., 31, pl. i, fig. 7 a ; Mayr, Europ. Cyn., 19.

Brownish-black, the face and orbits brownish-red, and the base of the antennæ red; the rest brownish, the thorax darker coloured than the abdomen, especially at the sides; the knees pale; thorax smooth, sericeous, the second abdominal segment sparsely pilose towards the base. Agamic $q$.

Length $3 \frac{1}{2}-4 \mathrm{~mm}$.

Gall.-The gall appears in April, and is found on the thick roots or on the trunk where a wound has been. When young it is hemispherical or oval, succulent, fleshy, and covered with a reddish or pinkish-yellow skin. This early top gall drops off when mature, leaving the gall proper embedded in the bark below its surface. They are gregarious, convex, with a large cell and with thick walls. The top falls off with the escape of the insects, leaving a rugged rim, showing a circle of canals on the outer edge. The galls are not easily seen until the insects have left; then the hole makes them readily visible.

The inquiline is Synergus incrassatus, the parasite Torymus corticis, Gir. (Giraud).

Sexual Form.-Black, shining; legs yellowish-red; the coxæ at the base, the hinder, except at the apex, and hinder tibiæ brownish ; antennæ brownish, yellow at the base; ventral surface of abdomen brownishred.

The $\delta$ has the colour of the femora much lighter in tint; otherwise as in $q$.

Length $1 \frac{1}{2}-2 \mathrm{~mm}$.

Appears in July. 
Gall.-Found on adventitious buds in May and June. Length hardly $2 \mathrm{~mm}$. Oval, sometimes narrowed at the apex; base smooth, green when young, greenish-white or brownish when older. Sometimes it is found on the apex of young leaves.

Widely distributed.

Continental distribution: Sweden, Germany, Austria.

\section{A.NDRICUS COLLARIS.}

Pl. V, figs. 5 (curvator) and 5 a (collaris) ; Pl. XIV, figs. 4 (curvator), $4 a, b$ (collaris); PI. XIX, fig. 2.

Cynips collaris, Htg., Germs. Zeits., ii, 190; Schenck, Nass. Cyn., 54, 61, and 115 .

Aphilothrix collaris, Mayr, Eichengallen, 25, 32, pl. iv, fig. 32 ; Adler, Zeits. wiss. Zool., xxxv, 177, pl. x, fig. 9 ; Licht. Cyn., 35, fig. 9 ; Fitch, Trans. Essex Field Club, ii, 137, fig. 27.

Andricus collaris, Mayr, Europ. Cyn., 22.

Cynips cuvvator, Thoms., Opusc. 785.

Andricus curvator, Htg., Germs. Zeits., ii, 191 ; Schenck, Nass. Cyn., 74, 76, and 109; Mayr, Eichen. gallen, 40, pl. $\mathrm{v}$, fig. 56 ; Adler, Zeits. wiss. Zool., xxxv, 178, pl. x, fig. $9 a$; Licht. Cyn., 36, pl, i, fig. $9 a$; Mayr, Europ. Cyn., 20 ; Fitch, Trans. Essex Field Club, 140, fig. 33.

Black, shining, the face finely rugose; the mouth, the five to six basal joints of the flagellum of the antennæ, the pronotum, the base of the mesonotum, the sides, and two narrow lines on the black part, the scutellum, the sides and ventral surface of the abdomen, and legs (the coxæ black, reddish at the apex) reddish; the legs of a clearer and more yellowish tinge than the rest of the body. Abdomen very sparsely pilose at the base. Wings hyaline. Agamic + .

Length $3 \cdot 3-5 \mathrm{~mm}$.

What I have called "black" may be brownish or brownish-black, and the quantity of red on the thorax and abdomen may be more or less than what I have noted in my bred specimens described above-some specimens, in fact, being very light and others very dark coloured. A specimen of the very light type of coloration is figured on $\mathrm{Pl}$. XIV, fig. $4 \vec{b}$. 
Gall.-Found in the terminal or lateral leaf-buds, hidden as a rule by the scales, so that only the apex is visible. Hard, woody, conical or oval, sometimes almost roundish; smooth, the apex narrowed to a point, forming a blunt cone surrounded by a zone differently coloured from the rest of the gall, being usually brownish at the extreme apex, the rest being yellowish.

Schenck (l. c.) says that the galls remain in the bud after the larvæ have come to maturity; but I believe that it is only those galls tenanted by the inquilines which stick to the buds, those frequented by the host falling to the ground. The flies come out in April of the second year, remaining thus eighteen months in the gall.

The inquilines are Synergus nervosus, and, according to Schlectendal, S. E. Z., 1870, 341, S. pallipes (probably a variety of $S$. Tschelii).

The same author bred Eurytoma verticillata, Nees, from the galls. Brischke records Syntomaspis caudatus as a parasite.

Sexual Form.-Black, shining, the base of the antennæ pale; the legs testaceous; the coxæ at base, the base of the four anterior femora, and the posterior, except at the apex, blackish or brownish; wings clear hyaline, shining; the mesonotum impunctate or only punctured at the sides; the mesupleuræ shining, impunctate; pronotum transversely striolate; the scutellum rugulose. Antennæ thickened towards the apex, the twelfth and thirteenth joints not much longer than broad.

The $\delta$ is similar, has the antennx lighter in tint, and with the third antennal joint curved and thickened a little.

Length $1 \frac{1}{2}-2 \mathrm{~mm}$.

Gall.-Forms irregular swellings on young aborted leaves, or on the sides of more or less developed leaves. At first they are hard and solid, but with growth they expand and form a large internal cavity of a more or less circular form, inside of which is the brownish egg-shaped inner gall loose. In colour they are always green, like the young leaves. Sometimes they form terminal swellings which become hard and bark-like externally, from which twigs and leaves may 
be developed as in inflator. Found in May and June, the flies issuing in the latter month. The outer gall may be single, or have two cavities divided by a septum. The insect emerges in June.

Synergus albipes, S. facialis, and S. radiatus are common inquilines in these galls.

Brischke (Schr. d. Naturf. Ges. zu Dantzig, v) gives as inquilines Periclistus Brandti, Synergus apicalis, and S. thaumacera; and as parasites Pteromalus meconotus, P. Saxesenii, Entedon cecidomycarnus, Mesopolobas fasciventris, Telenomus phalænarum, Platymesopus Erichsoni, and Decatoma biguttata. Eurytoma ros $\mathscr{X}$ is a common parasite.

Of parasites there have been been noted Torymus abdominalis, T. auratus, Fons.; Syntomaspis dubius, Nees (Giraud); Decatoma Neesi, Foerster (Giraud); Pteromalus dissectus, Walk. (Giraud); P. Erichsoni, Rtz. (Giraud); P. jucundus, Walk. (Giraud); $P$. cordairii, Rtz. (Kirchner); Pleurotropis metallicus, Nees; Eulophus metallicus, Nees, and Elachestus petrolatus, Nees. ơ (Giraud); Siphonura viridiænea, Rtz. (Kirchner); Eulophus lavissimus, Rtz. (Kirchner); Entedon scianurus, Rtz (Kirchner); Eupelmus annulatus, Nees (Giraud).

Of universal distribution.

Continental distribution: Sweden, Switzerland, Germany, Austria.

\section{ANDRIOUS RAMULII.}

Pl. VI, figs. 2 (ramuli) and $2 a$ (autumnalis); Pl. XV, fig. 1 (ramuli) i.

Cynips quercus-ramuli, Linn., Syst. Nat., ii, 918; Marshall, E. M. M., iv, 8.

Teras amentorum, Htg., Germs. Zeits., iv, 408.

Andricus ramuli, Schenck, Nass. Cyn., 74, 80, and 120; Mayr, Eichengallen, 56; Adler, Zeits. wiss. Zool., $\mathrm{x} \times \mathrm{Xv}, 186$, pl. $\mathrm{x}$, fig. $13 a$; 
Licht. Cyn., 47, pl. i, fig. $13 a$; Mayr, Eur. Cyn., 15 ; Fitch, Trans. Essex Field Club, ii, 146, fig. 46.

Cynips autumnalis, Htg., Germs. Zeits., iii, 336; Schenck, Nass. Cyn , 54, 61, and 115 .

Aphilothrix autumnalis, Mayr, Eichengallen, 24, 31, pl. iv, fig. 31 ; Adler, Zeits. wiss. Zool., xxxv, 185, pl. x, fig. 13, Licht. Cyn., 46, pl. i, fig. 13 .

Black; abdomen reddish-brown below, blackish above; legs yellowishred, the coxæ brownish at the base; antennæ brownish, the basal two joints yellowish-red. Wings hyaline. Agamic + .

Length $2 \frac{1}{2}-3 \mathrm{~mm}$.

Gall.-Found in the terminal leaf-buds, half hidden by the scales. Green when young, the shape an elongated oval, with a wart or conical point at the apex; when young covered with a succulent matter, giving it a brownish colour when old; the inner gall with longitudinal striations, not reticulations as in globuli. When old the outer skin falls away.

Found at the end of September and beginning of October, and falls to the earth at the middle of the latter month.

It is shorter and more spherical than the gall of collaris, but still being longer than broad; the collaris gall, too, wants the brownish succulent outer skin found in autumnalis ; it is greenish, not brownish, the conical point is more distinct, and there is no coloured ring. From the gall of globuli it is easily known by being longer than broad; like it, it has a succulent coat, but it does not become reticulated.

The inquiline recorded by Mayr is Synergus nervosus, and Schlectendal gives S. variolosus, Htg., a species not identified by Mayr in his monograph (S. E. Z., 1870 , p. 343). Brischke records Synergus ruficornis and S. apicalis. The latter authority gives Megastigmus dorsalis, Fab., as a parasite.

The galls drop to the earth in October, the flies coming out of them in April of the second year.

Sexual Form.-Reddish-yellow, shining; the vertex finely shagreened; the mesonotum finely punctured, dull ; the pleuræ shining and impunetate, the abdomen above more or less brownisk; antennæ entirely yellow; wings hyaline. 
The $\delta$ similarly coloured, the abdomen as a rule more widely infuscated; the third antennal joint is slightly curved.

Length $1 \cdot 5-2 \mathrm{~mm}$.

The amount of fuscous on the abdomen varies.

The only British species with which it can be confounded is amenti, which may be known by the black mesosternum.

The galls of this species are easily recognised by their forming a large mass like a ball of white wool. The size of the ball varies according to the number of galls composing it; for it is not made by one gall, but by a series of from 10 to 30 small, irregularly oval, brown, hard woody galls, each of which bear's long, white, wool-like hair. With age the hair becomes of a brownish-yellow colour, losing the white colour of its youth. At first the hair is more or less glutinous. Sometimes the mass contains only one or two galls, in which case it might be mistaken for the gall of cirratus; but the latter appears earlier, the flies also coming out sooner. The galls originate from the $\delta$ catkins, which are usually seen issuing from the woolly mass; but I have seen specimens which appear to issue from a leaf-bud; although it may really have been a flowerbud, the flowers of which had been aborted by the action of the gall-flies.

The inquilines are Synergus facialis, Htg., S. radiatus, Mayr, and Ceroptres arator, but the last may have come out of the twig galls of Andricus noduli.

Parasites.-Torymus auratus, Decatoma Neesi, Foer. (Giraud) ; Eunytoma semirufa, Gir. (Giraud); Pteromalus Ratzeburgi, Gir. (Giraud); Olinx debilis, Gir. (Giraud) ; O. gallarum (Brischke).

I have found a Tortrix larva feeding on the galls.

Of universal distribution, but local.

Continental distribution : Sweden, Switzerland, Germany, Austria. 


\section{ANDRICUS AMENTI.}

Pl. VII, fig. 7.

Andricus amenti, Giraud, Verh. z.-b. Ges. Wien, 1859, 360; Mayr, Eichen gallen, 57; pl. vii, fig. 82 ; Europ. Cyn., 14.

Reddish-yellow; the mesosternum black, the antennæ infuscated towards the apex; the vertex infuscated, finely shagreened, shining; mesonotum much more strongly and sharply shagreened; mesopleuræ shining, impunctate; wings hyaline. $q$ and $\delta$.

Length $1 \frac{3}{4} \mathrm{~mm}$.

The agamic form is unknown. That it has one may be taken for granted, but whether it is one of the galls at present known merely in the agamic state or some unknown form can only at present be conjectured.

Gall.-Found in June on the $\delta$ catkins. Length about $2 \mathrm{~mm}$. Cubital, rounded and narrowed at the base, tapering gradually to the apex; greenish when fresh, brownish when old, covered sparsely with soft pale hairs, the surface, when old, rough. As a rule the galls are in clusters of three or four. Sometimes the apex is nipple-shaped.

The gall is very similar to that of pilosus, but generally the latter may be known by being somewhat larger, not so globular, stouter, and not tapering so much at the apex, which is, as a rule, nearly as broad as at the base; the hair is longer.

No inquiline is known from it, but Giraud, its describer, gives Pteromalus dissectus, Wlk., P. Ratzeburgi, Gir., and Olinæ debilis, Gir., as parasites.

In this country it is only known from Braemar, where it was taken by Prof. Trail, and from Kew (Rolfe).

Continental distribution : Austria. 


\section{ANDRIOUS QUADRILINEATUS.}

Pl. VIII, fig. 3, gall; Pl. XV, fig. 4.

Andricus quadrilineatus, Htg., Germs. Zeits., ii, 190 ; Schenck, Nass. Cyn., 74, 77, and 111; Mayr, Eichengallen, pl. vii, fig. 84 (85); Europ. Cyn., 21; Fitch, Trans. Essex Field Club, 146, fig. 47.

Cynips 4-lineatus, Thoms., Opusc. Ent., 784.

Andricus flavicornis, Schenck, 1. c., 75 and 80.

- pedunculi, 1. c., 74, 77, 111.

- ambiguus, 1. c., 111.

- verrucosus, l. c., 112.

- glabrusculus, l. c., 112.

Aphilothrix quadrilineatus, Adler, Zeits. wiss. Zool., xxxv, 204, pl. ii, fig. 22; Licht. Cyn., 69, pl. ii, fig. 22.

Shining, finely shagreened, scutellum finely rugose, the pleuræ and median segment bearing a short whitish pubescence; brownish-red, two lines on the median lobe of the mesonotum, and one on the lateral and the scutellar foveæ black; vertex and antennæ infuscated or blackish; legs testaceous or pale brownish, the base of coxæ, trochanters, and more or less of femora infuscated. Wings clear hyaline, the nervures dark brownish ; the cubitus and base of radial cellule very slightly infuscated. $\circ$.

Length $2 \frac{1}{2}-3 \mathrm{~mm}$.

A very variable species, and impossible to be separated by any tangible characters from $A$. albopunctatus, A. callidoma, A. Malpighii, and A. seminationis.

The gall is found on the male catkins, usually gregariously. Their normal form is ovoid, but may be spherical, especially when attacked by Synergi; the surface is longitudinally furrowed, but not very regularly; at first the colour is whitish or reddish, then brownish, or brownish with a green tinge, almost glabrous. In length it is from $2 \frac{1}{2}$ to $4 \mathrm{~mm}$. It appears in May, and falls to the earth with the catkins, the insect emerging in the following spring, or even in the spring of the second year. A few specimens show a short blunt peduncle. On the whole it is rather a variable gall in form. The various species named by Schenck after the galls only were founded on these variations. 
Adler says that the species is found exceptionally on the leaves.

The Synergus is facialis.

The parasites are Torymus auratus and Olinx trilineata, Mayr.

Commonly distributed.

\section{Andricus Marginalis.}

Pl. VIII, figs. 5 and 6, gall.

Cynips marginalis, Schlechtendal, S. E. Z., 1870, 397 ; Mayr, Eichengallen, 52, pl. vi, fig. 76.

Aphilothrix marginalis, Adler, Zeits. f. wiss. Zool., xxxv, 208, pl. xi, fig. 21 ; Licht., Cyn., 68, pl. ii, fig. 21.

Andricus marginalis, Mayr, Europ. Cyn., 21.

Not to be known from $A$. quadrilineatus in the imago state.

Neither as regards the gall or insect is this to be known from A. 4-lineatus. I have no doubt that it is only Andricus quadrilineatus, the galls of which, as already indicated, occur on the leaves, and we know of other instances of the same species having galls in the catkins and leaves.

The gall of this species is found on the edge of the leaf, its position there being indicated by an incision; or it may be placed at the top of the leaf on the midrib, it being there also shown by an incurvation. It is sessile, and in form it is very irregular, varying from conical to roundish. The colour is green when fresh, and may be marked with reddish. The surface is smooth and glabrous, and is irregularly furrowed longitudinally. When old it is dark brown or dark whitish-yellow.

The galls are found in May, in which month they ripen, yielding the flies in the same month or in June. Those galls which have been "stung" by inquilines remain attached for a long time to the leaves. I have bred Olina trilineata from them.

A common if somewhat local species.

Continental distribution: Sweden, Germany, Austria. 


\section{ANDRICUS CIRRATUS.}

\section{Pl. VI, figs. 1 (Cirratus) and 1 a (Callidoma) gall ; Pl. XV, fig. 8.}

Cynips callidoma, Thoms., Opusc. Ent., 784 (?).

Aphilothrix callidoma, Adler, xxxv, 182, pl. x, fig. 11; Licht. Cyn., 41, pl. i, fig. 11.

Andricus cirratus, Adler, 1. c., 182, pl. x, fig. 11 ; Mayr, Europ. Cyn., 19 and 28; Licht. Cyn., 4,2, pl. i, fig. $11 a$.

- callidoma, Mayr, Europ. Cyn., 19, 21, and 28.

The agamic form is not to be recognised from the same form of A. quadrilineatus (see p. 95).

The remarkable gall of this insect issues from a leaf-bud (usually from small twigs), and occurs between June and October. It differs from all other galls in having a long peduncle at either end, the basal being the larger, and is, when normally developed, longer than the gall itself, the apical peduncle being much shorter, the longest I have seen not being much more than half the length of the gall. The gall proper is elongated, fusiform, broadly or sharply rounded at the ends; the surface generally smooth, glabrous when mature; the colour green or whitishgreen, sometimes with reddish longitudinal stripes, and some examples are longitudinally furrowed. The galls rarely hang downwards, usually they stand out obliquely from the buds.

The galls containing the makers fall to the ground when ripe, but those with inquilines remain attached; while, again, these latter vary considerably in shape, and have the peduncles very short or absent entirely.

The largest gall I have seen has the basal peduncle 12 , the gall 8 , and the apical peduucle $5 \mathrm{~mm}$. in length.

Malpighi (Opera Omnia, t. i, p. 122, fig. 44) figures a similar gall to this, but it may be the callidoma of Giraud (Verh. z.-b. Ges. Wien, p. 348), which differs from Adler's species in having the surface of the gall "couverte d'une pubescence très apparent, VOL. IV. 
dirigée de haut en bas, et marquée de quelques côtes longitudinales tantôt assez saillantes et tantôt presque effacées." Mayr (Cyn. Gallen, p. 21) says that callidoma, Gir., and callidoma, Adler, are different species, and that the galls only through the pubescence are to be distinguished. As regards this latter point I may add that I have some young galls and some half-developed ones, inhabited by inquilines of callidoma, which bear a distinct whitish pubescence, depressed, moderately long, and directed from base to apex, but not very thick. As regards the distinction between the flies, I am unable to fix upon any tangible characters from the description of Giraud and Adler by means of which they could be recognised; and therefore I am inclined to look upon the two as identical.

It is worthy of note that the bud from which the gall originates is not distorted in any way.

Inquilines. - Synergus nervosus and $\dot{S}$. vulgaris. Giraud says that he has bred Ceroptres from the gall (l. c.), but no species is mentioned. Ratzeburg records Siphonura brevicauda as a parasite.

Sexual Form.-Black, shining; the abdomen brownish-red, darker above; the legs uniformly citron-yellow (except the coxæ at base); the antennæ yellowish-testaceous, somewhat infuscated at the apex. Wings clear byaline; the tegulæ and a line on the pronotum pallid-yellow.

The on similar.

Length $1.5 \mathrm{~mm}$.

Readily known by the uniform citron-yellow legs.

Gall.-Found in the $\delta$ catkins in May. Length about $2 \mathrm{~mm}$.; oval, rounded at base and apex; green when young, brownish and rough when old. From its base there issues from the stamens long white woolly hairs, which may be three or four times as long as the gall itself. They usually are placed in clusters at the bud, and form a mass of wool about $5-7 \mathrm{~mm}$. in length and breadth. The catkins are shortened by the galls, and seldom project much beyond the bud.

I have found the galls of callidoma in Glen Moriston 
in June ; in Mugdoch Wood in July and August. Fitch records it from Rayleigh; and Mr. Bignell takes it at Plymouth.

Continental distribution: Germany.

\section{Andrious Malpighit.}

Pl. VII, fig. 2, gall.

Aphilothrix Malpighii, Adler, Zeits. wiss. Zool., xxxv, 183, pl. xi, fig. 12.

Andricus nudus, Adler, l. c., 184, pl. xi, fig. 12 a.

- Malpighii, Mayr, Europ. Cyn., 21.

The agamic form not distinguishable from $A$. quadrilineatus.

Gall.-Found in the buds in October. Spindleshaped, shortly pedunculate, the apex pointed; green, smooth, often with reddish stripes.

It differs from the gall of callidoma in having the peduncle much shorter, and may even want it entirely; the former is thicker and shorter, and it appears in October, while callidoma is found so early as June. It is, however, to be remarked that when the galls of callidoma are attacked by Synergi the peduncle is shortened, so that in this case the distinction between the two is rather vague.

Sexual Form.-Black, the abdomen paler, beneath testaceous, the legs pale yellow; the four anterior coxæ at the base, the hinder for the greater part, brownish; sometimes the femora are infuscated ; the joints of the tarsi blackish. Antennæ with the basal four or five joints yellowish; the others darker or fuscous.

The $\delta$ has the femora and tibiæ blackish; only the two basal antennal joints are yellow.

Length $1.5 \mathrm{~mm}$.

Gall.-Found in May on the $\delta$ catkins, placed usually between the stamens. Length barely $1 \frac{1}{2} \mathrm{~mm}$. Bare, green when young, yellowish at maturity. In shape an elongated oval, the apex narrowed perceptibly. Sometimes with a distinct nipple-like point at the apex. 
'The insects are easily bred if the galls are collected well on in May.

I know the species only from Mugdoch Wood, near Glasgow.

Continental distribution : Germany.

\section{AndRICUS ALBOpUnCTATIA.}

$$
\text { Pl. VI, fig. 4, gall. }
$$

Cynips majalis, Giraud, Bull. Soc. Ent. Fr., 1868, liii (gall).

albopunctata, Schlechtendal, Stett. Ent. Zeits., 1870, 376. Aphilothria albopunctata, Mayr, Eichengallen, 67, pl. ii ; Adler, Zeits. f. wiss. Zool., $\mathrm{xxxv,} \mathrm{205,} \mathrm{pl.} \mathrm{xi,}$ fig. 23; Lichten., Cyn., 71, pl. ii, fig. 23; Fitch, Trans. Essex Field Club, ii, 138, fig. 29.

Andricus albopunctata, Mayr, Europ. Cyn., 21.

Similar in size, for'm, and coloration to A. 4-lineatus.

The gall is found in the buds in May and June, but not in those having leaves. It is conical, sometimes with a sharp point at the apex, but more usually rounded there. In colour green, spotted with white; the surface smooth, shining, unicellular, hard, and woody. It is found in May and June, and falls to the ground very shortly after making its appearance. Length 5-6 $\mathrm{mm}$. The colour varies somewhat, some examples being brownish or yellowish-green.

According to Schlechtendal the fly comes out in November. I have had them in March.

I have bred both Synergus radiatus and S. facialis, from the galls. Brischke gives Torymus rubricipes as a parasite.

Common.

Continental distribution: Germany, Austria, France. 


\section{Andricus seminationis.}

$$
\text { Pl. V, fig. 3, gall. }
$$

Cynips seminationis, Giraud, Verh. z..b. ges. Wien, 1859, 373; Mayr, Oyn. Gallen, 63, fig. 88.

Aphilothrix seminationis, Adler, Zeit. wiss. Zool., 1880, 202, pl. xi, fig. 20 ; Licht. Cyn., 67.

Cynips inflorescentiæ, Schlecht., S. E. Z., 1870, 396 (gall only). Andricus seminationis, Mayr, Eur. Oyn., 21.

Only the agamic form is known, and it is not distinguishable from $A$. 4-lineatus.

The gall is found on the catkins of the sessile oak. It is of the same form as that of $A$. callidoma, but the peduncle is very short or quite aborted. Spindleshaped, sometimes of an elongated ovoid form ; slightly pubescent when young, glabrous when mature; white with pink stripes when fresh, yellowish or brownish when mature; sometimes the sides bear indistinct keels. The flower branch may be thickened or distorted by the galls. They are found also on the leaves, which may be incised where the galls are seated.

They are found in May, become ripe in June, the imagos appearing in the following spring.

I have bred Synergus facialis from the galls; and Mayr, besides this species, S. albipes, Htg. The parasite is Eurytoma rosæ.

I only know this species from Mugdoch Wood. Continental distribution: Germany, Austria.

\section{ANdRicus GLANDULAt.}

\section{Pl. VII, fig. 5, gall ; Pl. XV, fig. 5 .}

Cynips glandulæ, Schenck, Nass. Cyn., 62.

Aphilothria glandulæ, Mayr, Cyn. Gall., 26, pl. iv, fig. 34. Andricus glandulæ, Mayr, Eur. Cyn., 20.

Reddish-brown; the mesonotum minutely punctured, the scutellum much more coarsely; the scutellar fover and middle of median segment 
black; antennæ fuscous-black; upper surface of abdomen blackishbrown; sometimes the head in part and streaks on the mesonotum brownish; legs reddish-yellow, tibiæ brownish. Mesonotum alutaceous, aciculate, a longitudinal furrow between the parapsidal furrows.

Length $3 \mathrm{~mm}$.

Gall.-This is an easily recognised gall from the long white glistening hair with which it is covered, and from the truncated apex with a nipple-like point in the middle, the base being swollen. It issues from the lateral buds; is woody in texture; the base when fully developed is as wide as the gall is long; the top is narrowed, sometimes depressed ; and the nipple-like point is glabrous and yellowish. The colour is green, but more or less whitish from the long, silky, recurved, glabrous hairs. The dilated basal region, when freely developed, contains a cavity which is separated from the upper larval chamber, which occupies the narrowed upper region. When young or when the gall has been distorted by inquilines the base is not dilated, and its centre may be either hollow or filled up with a spongy substance.

Mr. Bignell has reared Synergus radiatus from the galls.

Of extensive range in this country, but not common. Clydesdale, Lymm, Nottingham, Devonshire (Bignell).

The insect emerges in the spring, and is probably agamic.

Continental distribution : Germany, Austria.

\section{ANDRicus solitarios.}

\section{Pl. VII, fig. 4; Pl. XV, fig. 3.}

Diplolepis solitarius, Fonsc., Ann. Sc. Nat., 1832, t. xxvi, 184.

Cynips ferruginea, Htg., Germs. Zeits., ii, 189; Sch., Nass. Cyn., 55, 62, 116, and 134 .

Aphilothrix solitaria, Mayr, Eichengallen, 23, pl. iii, fig. 29 ;

Fitch, Trans. Essex Club, ii, 136, fig. 24 .

Andricus solitarius, Mayr, Europ. Cyn., 25. 
Yellowish-ferrugineous; the pro- and mesonotum more or less, the scutellar foveæ and the centre of the median segment blackish; the vertex and pleuræ sometimes infuscated; the basal joints of the antennæ pale yellow, the apical infuscated; legs pale yellow, the base of coxæ and sometimes the hind tibiæ and tarsi infuscated; wings distinctly smoky, especially before the cubitus. Head and thorax witl the pubescence close, short, and white; the third abdominal segment impunctate; the second covered with a whitish pubescence to the apex; ventral sheath three times longer than broad. Head and thorax shagreened, opaque.

Length $2 \frac{1}{2}-3 \mathrm{~mm}$.

Hartig and Schenck describe the body as being entirely ferrugineous-red; but this is certainly not the case with the specimens I have bred, these having the head and thorax infuscated.

From corticis, Sieboldii, and radicis it may be known by the third abdominal segment not being punctured, and the head and thorax not being so thickly haired; from fecundatrix and globuli by the head and thorax not being black.

A gall well marked from its being thickly covered with ferrugineous hair. It is found either issuing from a terminal bud or from a lateral one along with a developed leaf, the gall in the latter case being placed above the leaf. It is spindle-shaped, pointed, and narrowed at the apex, this terminal point being sometimes curved and bare or nearly so. When in the axillary bud the gall at the base is bordered by small bracts. It is woody and hard in texture, and contains one large larval chamber. When young it is green, but soon becomes ferrugineous or reddish-brown.

Length about $7 \mathrm{~mm}$.

It is found from July to August, and becomes ripe in September. When the galls have been a long time in the twigs the pubescence gets completely rubbed off, its colour then being dark brown.

The only flies I have myself obtained were some which I cut out dead from the galls in the spring; but how long they were dead I am unable to say. Mayr gives September as the time in which the flies emerge; if so, it may be concluded it may have a bisexual generation. May that be Andricus amenti? Beyer- 
inck (Beob. ü. d. ersten Entw. einiger Cynipidengallen, p. 138) gives Neuroterus aprilinus as the spring generation, but apparently in error.

Not uncommon in Scotland; also in Nottinghamshire (Rothera and Ransom), and Fitch includes it in his list of Essex galls (l. c.).

The inquilines are Synergus vulgaris, S. facialis, and S. radiatus.

Eupelmus azureus is given as a parasite by Ratzeburg, and Mayr bred Olinx trilineata, sibi., and Eurytoma setigera, Mayr.

Continental distribution: France, Switzerland, Germany, Austria.

\section{ANDRICUS CLEMENTINA.}

Pl. VI, fig. 3, gall; Pl. XV, fig. 2.

Cynips clementinæ, Giraud, z..b. Ges. Wien, 1869, 349.

Andricus clementinæ, Mayr, Eur. Cyn., 24.

Dark brown or reddish-brown, covered with long, thick, stiff hair; the head for the greater part, the orbits always, and the mesopleuræ more or less spotted with reddish-brown; the apex and ventral surface of abdomen brownish-red; legs dark brownish-black; the knees and under side of the femora reddish-brown. Wings clear hyaline, large. Abdomen short. Antennæ darls brown, bearing white bristly hair ; 14-jointed.

Length $4-4 \frac{1}{2} \mathrm{~mm}$.

This gall is elongated at base and apex, the elongation forming a nipple-like point; the colour is dark yellow; the surface is rugose or granular, and bears several flattish projections of a deeper colour than the gall itself, and incurved hairs of a glistening white colour, these being especially thick at the apex. The length is about $5 \mathrm{~mm}$., and they are found in the leaf-buds. The inner larval chamber is free, being separated from the yellowish outer layer of cells by a small space.

Found in late autumn (October to November) on 
Quercus sessiliflora; the flies come out in February and March, according to Mayr.

Mayr gives Synergus melanopus and S. vulgaris as inquilines. I can find no mention of any parasites except Olinx trilineata, Mayr, recorded by Mayr.

I have only found this species in Cadder Wilderness, near Glasgow.

Continental distribution : Sweden (?), Austria.

The following gall is found at Kew Gardens on Quercus cerris.

\section{Andricus circulans.}

Pl. V, fig. 1, gall ; Pl. XV, fig. 6, ơ .

Andricus circulans, Mayr, Cyn. Gallen, 30 ; Eur. Cyn., 17.

Black; the coxæ dark brownish; the femora somewhat dull reddishyellow, more or less infuscated in the middle; the tibiæ and tarsi reddish-yellow; wings hyaline, the nervures pale fuscous; the antennæ brownish, the second joint and the base of the third paler than the others. Front and vertex finely and sharply punctured; the mesonotum with the puncturing finer and more shining; the scutellum coarsely rugose; the mesopleuræ finely longitudinally striated. $q$.

Length $2 \mathrm{~mm}$.

The $\delta$ similar in punctation and colouring; the antennæ 14-jointed.

The galls are found on the axillary leaf-buds of Quercus cerris gregariously, one, four, or eight being found in a bud; and they may be packed so closely together that they become compressed and flattened. They are glabrous, well hid in the bud, in colour varying from brownish-yellow to bright red; thin-walled; in shape an elongate ovoid, and in length $2-5 \mathrm{~mm}$.

Miss Ormerod found at Kew some galls which, although not quite typical, yet still may safely be referable to $A$. circulans. My figure is taken from a specimen I had from Prof. Mayr.

According to the latter authority, the normal time 
for the flies issuing from the galls is towards the middle of April.

Mayr reared Ceroptres cerri and some Pteromalidx from the galls.

Mayr found the galls in stubs near Vienna.

\section{Andricus mistivalis.}

$$
\text { Pl. IV, fig. 5, gall. }
$$

Andricus cestivalis, Giraud, Verh. z.-b. Ges. Wien, 1859, $35 b$; Mayr, Eichengallen, 55, fig. 79; Eur. Cyn., 16 ; Kaltenbach, Pfl., 672.

Black; head and thorax opaque; the antennæ, tegulæ, legs, and ventral surface reddish.testaceous; the wings hyaline, the nervures reddish. The antennæ stouter than usual, 14-jointed, the joints beyond the third moniliform; the third twice longer than broad, curved at the base, dilated at the apex. Head and thorax rugulose, sparsely covered with a pale pubescence; opaque; the mesoplenræ opaque, finely and closely coriaceous. $\delta$.

Length $2-2 \frac{1}{2} \mathrm{~mm}$.

The galls occur in masses on the male flowers of Quercus cerris. At the base the galls are closely pressed together, but not at the apex, the apex being very much wider than the base. The gall proper is at the bottom, and is surrounded by a wall which springs from the base and goes above it, leaving a large, empty, cup-shaped space in the centre. The gall is hard and woody, and contains one or two cells, the cells being ovate, and having a length of from 2.5 to $3 \mathrm{~mm}$. The colour of the gall is whitish or greenish-white, and much paler than the outer skin and the surrounding membrane, which is brownish, more or less mottled with yellow. In shape it is roughly conical, with a projecting point at the apex. The outer membrame becomes shrunk and twisted, and frequently curls inwardly over the top. The size of the mass of galls varies, some being as large as a walnut. The petiole bearing the galls becomes thickened and somewhat twisted. 
The flies appear at the beginning of July. It is not known if they have an agamic generation. From the experience of Giraud the ${ }^{*}$ must be very rare, for among 200 examples he only found four males.

Mayr records Torymus regius, and Giraud Elachestus gallicolus, Gir., as parasites, and the latter gives his Aulax pinnatus as an inquiline.

Austria.

I introduce this species on the authority of a $q$ which I captured at Loch Lomond, and which agrees very well with a type I had from Prof. Mayr. If not zstivalis, it is certainly different from any of our other British species.

The following table shows the time of appearing of the species:

\begin{tabular}{|c|c|c|c|}
\hline Agamic. & Time of appearing. & Sexual form. & Time of appearing. \\
\hline 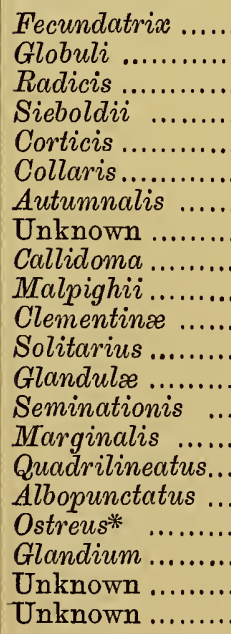 & $\begin{array}{c}\text { April } \\
, " \\
", \\
", \\
\text { April } \\
\text { - } \\
\text { September } \\
\text { April } \\
, " \\
\text { ", } \\
\text { October-March } \\
\text { = } \\
\text { - }\end{array}$ & 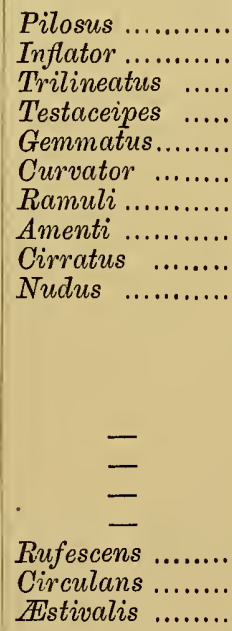 & $\begin{array}{c}\bar{z} \\
\bar{z} \\
\bar{P} \\
\text { April. } \\
\text { July \& August. }\end{array}$ \\
\hline
\end{tabular}

*Adler suspected that Neuroterus aprilinus was the spring form of this species, but Beyerinck (Beob. ü. d. e. Entwick. einiger Cynipiden-Gallen, p. 37) states 
that he has bred from ostreus galls a sexual form which lives in small bud-galls; he does not describe either the insect or gall, and names it Neuroterus furunculus.

The following unknown galls may be here described.

Miss Ormerod (Ent., xii, p. 193) describes and figures the under-noted galls, which are probably formed by an Andricus.

"The bud-gall (Pl. XVII, fig. 8, after Ormerod) which is figured both natural size and magnified, much resembles a stunted form of $A$. collaris, but is much smaller, and remains to maturity buried in the budcells. I have found it rather numerously in winter and spring, but as it does not make the slightest show externally, and the buds in which it is contained are not distinguishable from the others, I have only come on it accidentally during search for possible winter developments of details of gall-growth, and the gallmaker has been too much crushed to rear for definition. It is somewhat oval in shape, single-chambered, with a thin crisp wall, and from the varying conditions in which I have found it, appears to form (accompanying the growth of its larval tenant) during the latter part of the winter and beginning of spring, the imago quitting it before the season of expansion of the healthy buds. I conjecture that this very minute gall is much sought after by birds, as in the seasons when I have found most of it I have noticed the buds frequently torn open, and there is no other bud-gall common in the district at that time so far as I am aware.

"The other gall (Pl. XVII, fig. 9, after Ormerod) figured is very unusual in appearance, and has caused such complete distortion of all the surrounding growths as to make it difficult to convey with the pencil any characteristic forms. As seen magnified, it much resembles an abnormal form of Andricus inflator. It, however, consists of two oval cells. These are rather thin-walled, placed side by side, and 
occupying the entire width and about two-thirds of the length of the irregular hollow chamber formed by the swollen base of the stem in which they are contained, the outer walls of the gall-cells and the inner walls of the gall chamber being adnate for (approximately) half the cell surface. The gall-cells are not quite an eighth of an inch in length, and were deserted when I found the specimen-the only one which I have seen of this kind, and differing so much from any normal state of bud-gall with which I am acquainted, that possibly a figure may be of some interest."

In the E. M. M., iv, p. 146, there is the following note from the Rev. T. A. Marshall:- "Among the insects referred to is a genuine Cynips reared by $\mathrm{Mr}$. Parfitt from "woody galls near the base of oaks." Although no existing description fits this specimen, it may be the C. ilicis of Fabr. (S. Piez., 145, No. 10 : "Atra, nitida, thorace pedibusque pallide flavis").

\section{Cynips ?}

"Head, prothorax, and scutellum rufo-testaceous, coriaceous, hardly pubescent; declivity of the metathorax and the abdomen black. Legs testaceous; coxæ and a line on the middle and hinder femora and tibiæ blackish; tarsi broken off. Antennæ 14jointed, testaceous, the last four or five joints black. Eyes fuscous. Head large, as broad as the prothorax, subrugose. Prothorax transversely rugose, the parapsidum suturæ very distinct. Scutellum coarsely rugose-punctate, red, bordered all round with black; in the black hinder margin are two smooth foveolæ. Abdomen two-thirds as broad as the thorax, raised and compressed at the apex, which forms a sharp carina above; shining black, reddish laterally at the base. Ovipositor testaceous. Wings hyaline, the nervules pale testaceous, except the apical half of the subcostal, the basal transverse vein, 
the base of the radial cell, and the outer side of the areolet, which are black and incrassated.

Long 1 ; alar exp. 3 lines."

What this species may be I know not.

\section{Cynips Gemmæ?}

Pl. IV, fig. 2 (after Ormerod); Pl. XVII, fig. 7.

Cynips gemmea, Giraud, Verh. z.-b. Ges. Wien, 1859, 372; Mayr, Eichengallen, xxxiii, fig. 43.

Miss Ormerod (E. M. M., xii, 197) relates finding a gall at Isleworth which may be this little-known species. She says, "The gall is about a quarter of an inch in diameter, irregularly spherical, about twothirds of it above the upper surface of the leaf thickly beset with spines, for the most part simple, but in some cases branched. The colour yellowish-green with a mixture of rose, especially on the spines. Internally the gall is single-chambered, with a hard woody wall, about a quarter of the diameter of the gall in thickness."

Miss Ormerod alludes to the resemblance of these galls to the descriptions of Giraud and to the figures of Mayr. Gemmæ is very little known, and the maker not at all. I am indebted for a few specimens to Prof. Mayr, and I figure them on Pl. XVII, fig. 7, to show their resemblance to those figured by Miss Ormerod.

There are also the acorn galls found by myself in Clydesdale, from which, however, I only reared Synergi. The acorns were about half the ordinary size, apparently not distorted outwardly, and the two Synergi lived in oval cells. Rothera (Ent., xi, p. 206) states that he found at Ollerton a thin, shelly, unilocular gall lying loosely within the acorn case, and containing a large, fat, white, mandibulate larva, closely resembling that of $C$. Kollari. 


\section{Genus Crnips.}

Cynips, Linné, Syst. Nat., Ed. xii, p. 917; Hartig, Zeits. f. Ent., ii, p. 185; Mayr, Genera, p. 28.

Abdomen from the third segment covered thickly with silky pubescence, this being also the case with the legs, head, and thorax. Head dilated behind the eyes. Parapsidal furrows distinct, nearly parallel. Scutellum broader than long, and with two foveæ at its base, these being closed internally by a sharp ridge. Antennæ 14-jointed (in our species); stout, the second joint longer (in our species) than broad. Olaws on anterior tarsi bidentate. Radial cellule elongate, lanceolate at apex, open at fore-margin. Agamic.

This genus is well known by the rich silky pubescence on the abdomen, that organ in the other genera being glabrous. It is further distinguished by being unisexual. The species are the largest known among the gall-making group. Of the eighteen European species described, only one, C. Kollari, is native. One European species (C. conifica, Htg.) has the antennæ 13-jointed.

The genus Aphelonyx, Mayr, has the abdomen silky haired, but it differs from Cynips in having the anterior tarsi with the claws entire, the antennæ longer and more slender, the parapsidal furrows not complete, the scutellum as long as broad, and with an entire transverse fovea at its base.

So far as we at present know, all the species of Cynips are agamous, and only exist in the agamic condition, the spring bisexual generally found in Andricus, \&c., being unknown. The genus contains the largest species in the family, their galls also being, at least for the monothalamous galls, the largest. 'The majority of these remain attached to the buds until they drop off from the effects of the weather. In them the insects remain for the greater part of the year unchanged. As in Andricus, many of the species cannot be separated in the imaginal state; but the galls are very distinct, and not a few of them very striking in appearance. Eighteen European 
species are known, almost entirely from the middle and south. The genus is unknown in Scandinavia, and it is a moot point if our own species (Kollari) is really native.

\section{Cynips Kollari.}

Pl. II, figs. 6 and $6 a$; Pl. XVI, fig. 6 .

Cynips Kollari, Htg., Germs. Zeit., iv, 403; Mayr, Eichengallen, xvi, fig. 18; Schenck, Nass. Cyn., 55 and 64 ; Mayr, Eur. Cyn., 30; Mayr and Newman, Ent., No. 135, 1874, 241 ; Fitch, Trans. Eissex Field Club, 135, fig. 22.

Cynips lignicola, Marshall, E. M. M., iv, 7 ; cf. also Stainton, Trans. Ent. Soc., 1855; Proc., p. 76; Zool., 1855, 4747; Parfitt, Zool., 1856, 5074 .

Reddish-yellow; the scutellar fovex, the median segment, and more or less of the abdomen above black; the legs paler than the body; the fore-tibia with short depressed hairs; the antennæ 13-jointed; the basal joint paler than the others; wings hyaline, with a reddish tinge. $q$.

Length $4-5 \mathrm{~mm}$.

According to Mayr, Cynips corruptrix, Schl., $O$. aries, Gir., O. lignicola, Htg., C. tinctoria, C. caliciformis, and C. galeata, Gir., cannot be distinguished from Kollari in the imago state, but the galls are very different with all of them. This gall-fly was long known as the Devonshire gall, apparently- from its baving been first noticed in Devonshire. It was first brought before the entomologists of this country in 1854 by $\mathrm{Mr}$. Rich, who reported it as being very abundant in Somersetshire and Gloucester ("Proc. Ent. Soc.,' 2nd series, vol. iii, p. 35). Mr. Stainton stated (l. c.) that he had noticed the galls in Devonshire for the last four or five years; Mr. Parfitt that he had seen them about 1848 ; and lastly, Mr. Jordan (l. c., p. 40) remarked that he had observed them twenty years before, which would bring the earliest notice of the galls in this country to, say, 1834. 
That at first the gall was very local there can be no doubt, for we have the clearest evidence of its gradual extension over Britain during the last thirty years. On this point Dr. Jordan (E. M. M., viii, p. 51) remarks of Kollari: "Although noticed by me in Devon certainly for forty years at least (since we used its galls as marbles when I was quite a child), yet it did not reach Birmingham until 1860, when it was first noticed by me in the town, a fact not to be wondered at, considering how often its galls were brought from the south by tourists; it was not, however, until the autumn of 1866 that it was first seen by me invading Birmingham, along the hedges on the Worcestershire side; the two streams have now met, and $C$. Kollari is now found in both town and country." That has practically been my own experience in Scotland, where it now extends into Sutherlandshire.

Various attempts have been made to utilise these galls for ink-making purposes, but without any practical result, owing to the paucity of tannic acid they contain as opposed to the Aleppo and other gallsonly some 17 as against over 50 per cent. The only use made of them is for ornamenting fancy baskets, fern cases, \&c.

That the species is injurious in many instances there can be no doubt. It only frequents stub or young oaks, not over three or four feet high. These, when they appear in numbers in nurseries, they frightfully distort, and not infrequently render saleless.

As parasites there have been recorded Torymus regius $=$ Devoniensis, Parfitt, and Megastigmus stigmaticans, these two being not uncommonly bred from them in this country; Decatoma sp. (Walker). Mr. Fitch (Ent., vi, 243) bred from a small bunch of galls : Orymrus punctiger, a Eurytoma, a Pteromalus, a Torymus allied to inconstans, a "small black Hymenopteron quite unknown to Mr. Walker," a " $\mathrm{n}$. g. allied to Entedon." Giraud bred Macrocentrus marginator, Nees, from the galls.

VOL. IV. 
The inquilines are Synergus pallicornis, melanopus, and Reinhardi, all of which have been reared from them here. Kaltenbach (Pfl., 668) gives S. facialis also as an inquiline, and, as indicated on p. 58, Billups records the rearing of Ceroptres arator from the galls, but it is quite possible that the specimens were reared from the twig galls of Andricus noduli.

The empty galls are much utilised by various outliving insects for purposes of pupation. Fitch (Ent., 1879 , p. 113) gives a list of the insects and their parasites raised by $\mathrm{Mr}$. Weston from a lot of the galls. These included six species of Lepidoptera, seven beetles, and thirty Hymenoptera. The latter included Dineura Degeeri (a birch-feeding species), Emphytus togatus, and Harpiphorus lepidus; nine species of Ichneumonidæ, one Braconid, Eurytoma rosæ, Syntomaspis caudata, Torymus regius, Megastigmus stigmaticans (the latter no doubt parasitic on the gall larvæ), a Lamprotatus, Pteromalus tibialis (also a gall larva parasite), two species of Homalus (H. auratus and $H$. coeruleus), two Crabronidæ, Odynerus trifascatus, and the bee, Prosopis rupestris.

The flies emerge in August or September.

Distribution: Germany, Austria.

\section{Genus Trigonaspis.}

Trigonaspis, Hartig, Germs. Zeit., ii, 186 ; Mayr, Genera, 30. Biorhiza, Westwood, Int., ii, 56 (part).

Agamic.-Apterous; parapsidal furrows incomplete ; antennæ 13 to 14 jointed; no keel between the antennæ; head not dilated behind; ventral thorn 2 to $2 \frac{1}{2}$ times as long as thick. The third joint of the antennæ twice as long as the fourth, the sixth to twelfth not longer, as thick. Scutellum separated from the mesonotum by a slight transverse furrow.

Sexual.-Antennæ 14-jointed $q$, 15-jointed $\delta$; flagellum rather slender, tapering towards the apex. Parapsidal furrows complete, distinct. Scutellar foveæ shallow, separated by a sharp furrow; the keel in front of them distinct, acute. Scutellum rugose. Median seg: ment with the keels parallel. Abdomen shorter than the head aud 
thorax united, smooth, shining; with the $\delta$ petiolate. Wings large, the radial cellule elongate, open; areolet distinct. Head and thorax black; abdomen reddish-yellow.

The wingless agamic form can only be confounded with Biorhiza, which is much larger than it, has a carina between the antennæ, the head dilated more behind the eyes, the ventral spine only 1 to $1 \frac{1}{2}$ times longer than wide, and the parapsidal keels complete.

The sexual form is easily known by the reddishyellow abdomen and large wings.

There are only two European species known, and the sexual form is one of the best marked in the whole family.

\section{Trigonaspis megaptera.}

Pl. I, fig. 4 (megaptera, renum) ; Pl. XV, fig. 7

Cynips megaptera, Pz., F. G., Heft 79, 7.

Trigonaspis crustalis, Htg., Germs. Zeits., ii, 195; Adler, Zeits. wiss. Zool., xxxi, 198, pl. xi, fig. $18 a$; Licht., Cyn., 62, pl. ii, fig. 18 a.

- megaptera, Marshall, E. M.M., iv, 272; Mayr, Europ. Cyn., 31.

Cynips crustalis, Thoms., Opusc, 782, 4 .

Biorhiza renum, Giraud, Verh. z.-b. ges. Wien, 1859, 362 ; Adler, Zeits. wiss. Zool., xxxi, 197, pl. xi, fig. 18; Licht., Cyn., 61, pl. ii, fig. 18.

Trigonaspis renum, Mayr, Europ. Cyn., 31 .

Agamic Form.-Apterous, yellowish-red, the abdomen darker, with the legs paler than the body; thorax punctured, opaque, abdomen shining; the vertex finely shagreened. Antennæ 13-jointed, the last joint twice the length of the penultimate; claws simple, dilated at the base.

Length $1.5 \mathrm{~mm}$.

The only other European species is B. synaspis, Htg., which may be known from ours by the claws being cleft, and by the antennæ having 14 joints.

Gall.-Small, 1-2 mm., irregularly kidney-shaped, greenish yellow, sometimes reddish; soft, succulent, usually crowded together along the nervures. Length 2 to $3 \mathrm{~mm}$. Found in the autumn, falling when 
ripe. The insects are very difficult to rear, and are very irregular in the length of time which they take to reach maturity. As Giraud has pointed out (l. c.), the galls inhabited by the gall-maker become black, regular and ovoid in shape; while those tenanted by parasites retain the irregular shape and the fresh colour.

The only British inquiline is Synergus thaumacera, but on the Continent S. varius, Htg., has been bred by Mayr; S. vulgaris by Giraud; Hartig mentions $S$. tibialis, Htg., as having been reared by him, and Brischke S. ruficornis and S. pallicornis.

Giraud bred Mesopolobus fasciiventris, West., Callimome fuscicrus, Gir., and von Schlechtendal a o Torymus. Brischke records Pteromalus Saxesenii, Pleurotropis cyrriphidum, and Mesopolobus fasciiventris.

Sexual Form.-Black, very shining; the abdomen bright reddishyellow, darkened at the apex; the legs yellowish-red, paler in tint than the abdomen, the coxæ at base infuscated; antennæ dull reddish-brown at the base, the apex darker; wings large, clouded at the base of the radial cellule and before the cubitus, the nervures dark fuscous; vertex shagreened; pronotum obliquely striolated, scutellum irregularly coriaceous, depressed in the middle above; pleuræ shining.

The $\delta$ similar, with the third joint distinctly curved.

Length, of 3.5 to $4.5 \mathrm{~mm}$., 02.5 to $3 \mathrm{~mm}$.

Gall.-Roundish, oval, or ovoid, of rather variable form and size; soft, smooth, succulent, white or creamy-white with reddish cheeks, sometimes almost entirely red; the central cavity small. Length from 3 to $8 \mathrm{~mm}$. When old they shrivel up and become wrinkled. They are found at the roots or on the trunks of old oaks at a distance of $\mathrm{l}$ to 3 feet from the ground, and arise from small buds, not from the bark, as might be supposed from a cursory examination. They are found either singly or in masses, and are frequently hidden by moss. They appear in May.

The inquilines are Synergus thaumacera and Synergus erythrocerus according to Hartig, and S. facialis and S. pallicornis according to Brischke.

As parasites it possesses Syntomaspis fastuosa; 
Torymus flavipes, Wlk.; T. amonus; Callimome rubriceps, Latr., according to Brischke, who also gives Limneria exareolata as a parasite.

Sweden, the Netherlands, Switzerland, Germany, Austria.

\section{Genus Bioritiza.}

Biorhiza, Westwood, Int.. ii, 56, App.; Mayr, Genera, 31. Apophyllus, Hartig, Germs. Zeit., ii, 185. Teras, Hartig, l.c.

Dryoteras, Foerster, Verh. z.-b. ges. Wien, 1869, 331.

Agamic.-Apterous. Parapsidal furrows entire, acute; a blunt keel between the antennæ; head dilated behind the eyes; ventral spine one to one and a half times as long as thick. A transverse furrow at the base of the scutellum. Antennæ 14-jointed; the third joint longer than the fourth. Mesothorax contracted in the middle. Abdomen large, somewhat compressed, longer than the head and thorax united. Cheeks hardly half the length of the eyes. Metanotal keels above parallel, then diverging, and converging again at the apex. Claws simple. On the mesonotum only the space between the furrows is smooth, the rest being aciculate.

Sexual Form.-The of agrees very closely with the agamic, but is usually winged; the wings having an open radial cellule, the radial cellule moderately long; the first abscissa of the radius curved; the areolet well defined. The antennæ are 14-jointed; the third joint longer than the fourth. Mesonotum smooth, impunctate all over; the mesonotum not contracted in the middle. The abdomen as long as the head and thorax. At the base of the scutellum are two distinctly separated foveæ.

The $\delta$ has the antennæ 16-jointed, the third joint curved; the head not dilated behind the eyes.

It is noteworthy that the sexual female may have the wings rudimentary or wanting; in which case it approximates in the shape of the thorax to the agamic. The $\delta$ so far as I know is never apterous nor with rudimentary wings. The colour of both forms is yellowish. There is only one European species, and one is known from North America. 


\section{Biorhlza terminalis.}

Pl. I, fig. 5 (terminalis); Pl. III (aptera) fig. 4; Pl. XV, figs. 9 (aptera), 9 a (terminalis); $\mathrm{Pl}$. XVII, fig. 8 (aptera).

Cynips quercus terminalis, Fab., E. S. Supp. 213; Thoms. Opusc., 782.

Teras terminalis, Marshall, E.M.M., iv, 148; Adler, Zeits. wiss. Zool., xxxi, 194, pl. xi, fig. 17 a; Licht., Cyn., 58 , pl. ii, fig. $17 a$.

Biorhiza terminalis, Mayr, Europ. Cyn., 32.

Cynips aptera, Fab., E. S. ii, 104; Thoms. Opusc., 782.

Biorhiza aptera, Marshall, E.M.M., iv, 172; Adler, Zeits. wiss. Zool., xxxi, 192, pl. xi, fig. 17 ; Licht., Cyn., 56, pl. ii, fig. 17 ; Mayr, Europ. Cyn., 32.

Agamic Form.-Apterous; yellow and red; the apical half of the antennæ and the apex of the abdomen more or less blackish ; vertex, front, and occiput opaque, closely punctured; mesonotum more shining, especially in the middle, more or less punctured in front; the mesopleuræ richly pilose, shagreened, propleuræ, closely punctured; scutellum flat, finely punctured, a deep and wide furrow at its base; parapsidal furrows generally complete and distinct.

Length 3.5 to $7.5 \mathrm{~mm}$.

The species varies greatly in length, and the smaller specimens have the sculpture much less clearly indicated than in the larger examples, while further the parapsidal furrows and the furrow at the base of the scutellum become more or less obsolete.

Gall.-Found on the roots of oaks. Form and size irregular, the latter ranging from 5 to $25 \mathrm{~mm}$. At first soft, white, marked with reddish, it becomes with age very hard and woody, and in colour brownish. They occur gregariously or solitarily, and the number of larval chambers varies.

The fly issues in December and January; climbs up the trunk of a tree, chooses a suitable bud, places its head downwards, tunnels the bud from right to left with the ovipositor, and then inserts the eggs, which are found almost in a mass at the bottom of the bud.

No inquiline is known from this gall. The parasite is Torymus nobilis. 
Sexual Form.-Yellow to yellowish-red; the apical half or so of the antennæ and the dorsum of abdomen more or less blackish; wings hyaline, the nervures pale fuscous. Head aciculate, somewhat opaque, the mesothorax more shining, slightly and very finely punctured, the pleuræ shining, impunctate; parapsidal furrows distinct; scutellum irregularly and finely rugosely punctured, and with two foveæ at its base.

Length $3 \mathrm{~mm}$.

The $\delta$ is always winged, but the $q$ not infrequently has the wings rudimentary or entirely obsolete, in which case there is a slight change in the convexity of the scutellum.

Gall.-The well-known Oak or King Charles' apple, and worn by country boys in England on the 29th May. Found on the terminal buds, very rarely in the lateral. In size very variable, the average having a diameter of about $20 \mathrm{~mm}$.; soft, spongy, white with rosy cheeks when young, older greyish or pale brownish-yellow. In the interior are found a large number of larval chambers of a yellowish-white colour; these cells being united by a spongy substance, soft and solid when young, becoming dry and friable when old. They occur in May and June, the flies coming out at the end of May or early in June.

I have never had any Synergus other than facialis from these galls, nor has any one else, so far as I am aware, except Walker, who records $S$. socialis as an inquiline. Socialis is a synonym of melanopus. $\mathrm{He}$ bred it in June of the same year, and also in March and April of the following year. The latter observation is, however, not consistent with what we know of the history of $S$. facialis, which always appears in June to July of the same year, so that it is quite possible that Walker may have really bred melanopus. On the other hand it may be that facialis, sometimes like so many of the true gall-makers, may take some months longer than usual to reach maturity.

Walker, it may be added, states that " a few specimens of other species of Cynipites appeared in the summer," but no further indication is given as to what these were. 
The parasites are rather numerous, but it does not follow that all those bred from the galls prey on terminalis, some of them feeding possibly on the inquilines. Torymus abdominalis, Boh., = cingulatus, Nees, = cyniphidum, Ratz.; T. regius, Nees, = inconstans, Walk.; longicaudis, Ratz., = leucopterus, Walk.; T. auratus, Fons., = viridissimus, Boh., = autumnalis, Walk., = confinis, Walk., = mutabilis, Walk., = leptocerus, Walk., = minutus, Walk., = muscarum, Nees, $=$ propinquus, Foer. = nanus, Foer., $=$ appropinquans, Ratz., = gallarum, Ratz. Syntomaspis caudata, Nees, = crinicaudis, Ratz.; Megastigmus dorsalis, F., = Bohemanni, Rtz, = xanthopygus, Foer.; Eurytoma rosæ, Decatoma biguttata, by Brischke, D. immaculata, by Walker, and D. signata, by Ratzeburg; Eupelmus urozonus, Olinx scianeurus, Rtz., sec. Mayr, = Euedoreschus, Walk.; Hulophus gallarum, L. (probably the specimens recorded under this name from these galls are only O. scianeurus); E. agathyllus, Walk. ; E. ramicornis (Brischke); Tetrastichus Diaphantes, Walk. Walker records the following species of Pteromalus: naubolus, ovatus, domesticus, delectus, fuscipennis, fusciventris, hilaris, platynotus, planus, decidens, semifasciatus, dubius, all described by himself. Ratzeburg gives as parasites, or at least as frequenters of the galls: Pteromalus Cordarii, Ratz.; meconotus, Ratz.; stenonotus, Ratz. ; leucopezus, Ratz. (?) ; gallicus, Ratz. ; and Dufourii, Ratz.; Platymesopus Westwoodi, Ratz.; $P$. Erichsoni, Ratz. Walker bred a Cerraphon and Inostenna Boscii, and Ratzeburg Dendrocerus Lichtensteinii, Walk., all three pertaining to the Oxyura. Various species of Ichneumonidæ and Braconidæ have been reared, but the majority preyed without doubt on casual dwellers in the galls, namely Pimpla calobata, Gr., P. caudata, Ratz., and P. alternans, Gr.; Hemiteles areator, Pz., H. coactus, Ratz., and $H$. punctatus, Ratz. (Ratzeburg); Lampronota segmentata, F.; Cryptus hortulanus, Gr. The Braconidx recorded are: Bracon caudatus, Apanteles breviventris, Ratz.; 
Microtypus Wesmaelii, Ratz.; and Microdus rufipes, Wesm.

Commonly distributed in Europe.

\section{Genus Dryophanta.}

Dryophanta, Foerster, Verh. z.-b. Ges. Wien, 1869, 335 ; Mayr. Genera, 35.

Liodora, Foer'ster, l. c.

Cheeks without furrow, half as long as the eyes. Antennæ 14, $q$, longish, the third joint not much longer than the fourth. Parapsidal furrows entire; in some species there is a transverse furrow at the base of the scutellum; keels on the median segment recurvate. Abdomen longer than the head and thorax; the second segment sometimes at the apex above produced. Claws bifid. Wings elongate; the radial cellule open, long, and narrow, the areolet present. Head, thorax, and legs thickly haired; the antennæ and tibiæ with long, stiff, erect hair. Ventral spine pilose. Thorax more or less punctured or aciculate.

The sexual forms have the body only very sparsely haired, the mesonotum without sculpture, and the antennæ and legs without stiff hairs. The head is not dilated behind the eyes; the ventral spine not thickly haired.

The $\delta$ has the antennæ 15 -jointed, the third joint emarginate, the abdomen petiolate.

The species are blackish, variegated with brownish, the legs reddish-brown, more or less black. The agamic females are mostly easily separated, but the sexual forms are so much alike that it is impossible to distinguish them.

Besides our species there are three other Palæarctic species known, namely $D$. pubesescentis, Mayr (=foli, Schenck, perhaps only a race of folii), $D$. cornifex, Htg., and D. flosculi, Gir. 


\section{Table of the Species.}

\begin{tabular}{|c|c|c|c|}
\hline Agamic form. & Time of appearing. & Sexual form. & Time of appearing. \\
\hline D. folii .... & January and & D. Taschenbergi & May and June. \\
\hline D. longiventris... & November & D. similis & " \\
\hline D. divisa ......... & October and & D. verrucosa...... & $"$ \\
\hline $\begin{array}{l}\text { D. agama .......... } \\
\text { D. disticha } \ldots . . . .\end{array}$ & $\begin{array}{c}\text { Novenoer } \\
", \\
",\end{array}$ & $\begin{array}{l}\text { Unknown .......... } \\
\text { Unknown ......... }\end{array}$ & \\
\hline
\end{tabular}

Synopsis of the Species.

1 (8) Antennæ and legs thickly covered with long, stiff, erect hairs; head and thorax for the greater part brownish-red. Agamic forms.

2 (7) Abdomen elongate; the second segment tongue-shaped, produced at the apex; projecting acutely above.

3 (6) The entire mesonotum thickly and uniformly haired.

4 (5) The twelfth antennal joint as broad as long; the femora reddishyellow, sometimes lined with black.

5 (4) The twelfth antennal joint broader than long, the femora brownish.

6 (3) The mesonotum not pilose all over. Agama.

7 (2) The second abdominal segment not produced greatly, and ending before the extreme apex; not acute or elongate.

Divisa and disticha.

8 (1) Head and legs not thickly covered with long stiff hairs; the head and thorax black; shining. Sexual forms.

A. Abdomen elongate; the second segment produced to the apex; tongue-shaped; projecting acutely above (Species 1 to 3 ).

\section{Dryophanta folit.}

Pl. I, fig. 6 (folii); Pl. II, fig. 5 (Taschenbergi); Pl. XVI, fig. 2 (folii).

Cynips quercus folii, Linn., S. N., ii, p. 918.

Diplolepis scutellaris, Oliv., Enc. Méth., v. 282. 
Cynips folii, Htg., Germs. Zeits., ii, 187 ; Thoms., Opusc., 790. - scutellaris, Schenck, Nass. Cyn., 56.

Dryophanta scutellaris, Adler, Zeits. wiss. Zool., xxxv, 186, pl. xi, fig. 14; Licht., Cyn., 48, pl.ii, fig. 14.

- $\quad$ folii, Mayr, Europ. Cyn., 36.

Spathegaster Taschenbergi, Schlecht., S. E. .Z., 1870, p. 391; Adler, Zeits. wiss. Zool., xxxi, 188, pl. xi, fig. 14 $a$; Licht., Cyn., 50, pl. ii, fig. $14 a$.

Dryophanta Taschenbergi, Mayr, Europ. Cyn., 35.

Agamic form.-Black; the orbits, sometimes the pleuræx, more or less of the mesonotum and of the scutellum, reddish-brown; the legs black, with the femora reddish-yellow, and tibiæ more or less brownish; wings elongate, hyaline, the nervures pitchy, the base of the radial cellule and the cubitus blackish, the nervures there thickened; the twelfth an. tennal joint as long as broad; antennæ brownish-black, the first and second joints sometimes reddish.

Length 3 to $3.5 \mathrm{~mm}$.

The femora are often lined with black. The hair is long and thick, and is equally distributed over the mesonotum, in which respect it differs from agama.

Gall.-The largest of the pea-shaped galls found on the underside of the leaf, but as regards its size it is well to note that in this respect it varies from 3 to 12 $\mathrm{mm}$. in diameter. It is found on the mid rib on the underside of the leaf, to which it is attached by a very small part only. It is spherical, smooth, sometimes with minute warts, yellowish-white, with usually the cheeks broadly bright red; soft and spongy, drying up when old, the surface then becoming irregular and gibbous.

It is found in July, falls to the earth when ripe, and delivers the fly in October.

The only inquilines mentioned by Mayr are Synergus pallicornis, S. Tscheki, Sapholytus connatus, but Hartig gives S. vulgaris and Neuroterus parasiticus as tenants.

The parasites are Syntomaspis lazulina, Torymus abdominalis, T. regius, Decatoma biguttata, Eurytoma setigera, Mayr; E. rosce. Kirchner mentions also Torymus incertus, Foer.; Pteromalus jucundus, Foer.; and $P$.fasciculatus. Ratzeburg records Porizon clavi- 
ventris, Gir.; Bracon aterrimus, Ratz. ; and Orthostigma gallarum, Ratz. Fitch (Ent., ix, 123) states Mr. Rothera bred (as named by Mr. Walker) Eurytoma nodularis, Megastigmus dorsalis, Callimome elegans, and C. antennatus.

Sexual Form.-Black, very shining, impunctate; scutellum opaque, finely rugose; very shortly and sparsely pilose; pleuræ shining, impunctate; legs jellowish or reddish-yellow, black at the base, the femora infuscated; wings hyaline, with a yellowish smoky tinge at the base. $q$ and $\delta$.

Gall.-Found in the adventitious buds at the foot of old oaks early in May. It is oval, rounded at the apex, about $3 \mathrm{~mm}$. in length, violaceous and velvety when young, the latter quality being caused by the surface being covered with microscopic whitish pile. The shell is thin, the larva occupying the entire interior of the gall. When old, the violet tinge and the velvety aspect disappear. Length $3 \mathrm{~mm}$.

Sometimes three or more galls are found touching each other; but they are also found singly.

This gall has a considerable resemblance to that of similis; but it may be known from the latter by being, as a rule, $1 \mathrm{~mm}$. longer, by the apex being broadly rounded, by the deeper violaceous tinge and more distinct velvety texture, and by the surface not bearing long white hairs.

A gall apparently that of Taschenbergi was found on Quercus cerris at Kew by Miss Ormerod, and is figured, Ent., x, 43.

Common.

\section{Dryophanta longiventris.}

Pl. II, figs. 1 (longiventris) and 1 a (similis).

Cynips longiventris, Htg., Germs. Zeits., ii, 188.

Dryophanta longiventris, Adler, Zeits. wiss. Zool., xxxi, 189, pl. ii, fig. 15; Licht., Cjn., 51, 
pl. ii, fig. 15 ; Mayr, Europ. Cyn., 36.

Spathegaster similis, Adler, Zeits. wiss. Zool., xxxv, 190, pl. xi, fig. $15 a$; Licbt., Cyn., 52 , pl. ii. fig. $15 a$; Mayr, Europ. Cyn., 35.

The only tangible points in which this species differs from folii are that the twelfth antennal joint is perceptibly longer than broad and that the femora are brownish.

The sexual form cannot be separated.

Gall (agamic).-Found in August, becoming ripe in October, when the flies leave them. They are situated on the nervures (the central or lateral) somewhat irregular in shape, hard and woody, about 7 to $8 \mathrm{~mm}$. long, and about 4 to $5 \mathrm{~mm}$. in height; the surface rough, gibbous, the gibbosities and the general surface whitishyellow, marked frequently with reddish bands; the red forming continuous bands or irregular spots. The central cavity small, the walls being thick. The apex is not depressed.

The inquiline is S. pallicornis, and, according to Brischke, S. apicalis. Parasites: Syntomaspis cyanea, S. lazulina, Torymus abdominalis, T. regius, Eurytoma rosæ. Brischke gives Callimome longiventris, Kaltenbach Entedon cyniphidium, and Ratzeburg Elachestus cyniphidium as parasites.

Gall (sexual).-Found on the adventitious buds on old oaks, sometimes also from those issuing from the bark, and also from the small twigs. Length about $2 \mathrm{~mm}$.; ovoid, pointed at the apex, green, velvety, covered with long whitish hairs, which are sometimes so numerous as to give the gall a whitish appearance.

It is found in May or at the end of April, the flies coming out early in May as a rule.

Distribution: common.

Germany, Austria, Switzerland. 
3. Dryophanta agama.

Pl. II, fig. 2.

Cynips agama, Htg., Germs. Zeits., ii, 188.

Dryophanta agama, Mayr, Europ. Cyn., 36; Eichengallen, 37.

The abdomen is formed as in foli and longiventris, with which it agrees closely in coloration of the body; but the legs are yellowishred with only the coxæ at base blackish; the antennæ are brownishblack, sometimes yellowish-red at the base, and the mesonotum has the hinder part in the centre very smooth and shining and almost glabrous; the forc part of the mesonotum too not being so thickly haired as in folii. It is also a smaller species. The twelfth antennal joint is distinctly longer than broad, as in longiventris.

Length $3 \mathrm{~mm}$.

The sexual form is unknown, but we have no definite evidence that it may not have a spring form.

Gall.-Length averaging $4 \mathrm{~mm}$., oval or ovoid; the colour pale yellowish, seldom or never with red or pink on the sides; the surface marked with asperities; the central hollow large, the shell being thin; found on the underside of the leaves, on the veins, in July and August.

Easily known from the galls of divisa by being smaller, more globular, and by the large central cavity.

The inquilines are Synergus pallicornis and S. albipes, and, according to Brischke, S. apicalis. Parasites: Syntomaspis cyanea; S. eurynotus, Foer. (Giraud); Torymus pubescens, Foer.; T. regius, Eurytoma signata (Kaltenbach) ; Eupelmus urozonus, Pteromalus fasciculatus, Foer.; P. fuscipalpis, Foer. Brischke records Torymus cultriventus, Ratz. (Mayr gives as the host of this species Harmomyia Fagi), T. abdominalis, Decatoma biguttata, and Eurytoma rosæ.

Not common, and local.

Germany, Austria. 
B. Second abdominal segment not produced greatly to the apex above, and ending before the extreme apex, not produced above, nor acute, nor elongate.

\section{Dryophanta Divisa.}

Pl. II, figs. 4 (divisa) and 4 a (verrucosa) ; $\mathrm{Pl}$. XVI, figs. 1 (divisa) and l a (verrucosa).

Cynips divisa, Htg., Germs. Zeits., ii, 188.

Dryophanta divisa, Adler, Zeits. wiss. Zool., xxxi, 190, pl. xi, fig. 16; Licht., Cyn., 53, pl. ii, fig. 16.

Spathegaster verrucosus, Schlecht., S. E. Z., 1870, 389; Adler, Zeits. wiss. Zool., xxxi, 191, pl. xi, fig. $16 a$; Licht., Cyn., 54, pl. ii, fig. $16 a$; Mayr, Europ. Cyn., 35.

Brownish-red; the antennæ, three large marks on the mesonotum; the scutellar fovea, the middle of the mesopleuræ, and the abdomen, black; the legs reddish-brown, the tint being redder than on the body; the base of coxæ and sometimes the tibiæ infuscated; the mesonotum and mesopleuræ thickly haired; the mesonotum punctured in front.

Length 3 to $4 \frac{1}{2} \mathrm{~mm}$.

The gall is smaller than that of longiventris, but is similar in shape, and, like it, is found on the veins on the underside of the leaf. The surface is smooth, glabrous, hard and woody, whitish-yellow, with cheeks usually bright red; the top as a rule is depressed in the centre. The larval cavity small, the walls being thick.

Frequently the surface bears a few minute warts; also the red colour may be entirely absent; and with age the colour becomes brownish. Over a dozen may be found on a single leaf.

Found from July onwards; the flies emerge in October.

Inquilines, Synergus pallicornis, S. Tschelci, and S. albipes.

Parasites, Syntomaspis cyanea, T. abdominalis, T. regius, Eurytoma setigera, Mayr ; E. rosæ, Pteromalus incrassatus (Brischke); Syntomaspis lazulina is re- 
corded by Giraud; Pteromalus Saxesenii, Ratz., by Ratzeburg; Torymus pubescens, Foer.; Eurytoma signata, Nees; Eupelmus urozonus, Dlm.; Pteromalus fasciculatus, Foer., by Kaltenbach ; Eurytoma squama, Wlk. ? ; Decatoma biguttata, Swed.? by Fitch (Ent., ix, $150)$.

The galls frequently occur in enormous quantities, covering and bending down the leaves. The specimens frequented by Synergi are often very minute.

Gall (sexual).-Found early in May when the leaves are beginning to expand, and generally on the terminal buds. They are usually on the young leaves, issuing from the mid-rib, or from the edge, the leaf being considerably distorted thereby; they may be also found in the buds. They are about $4 \mathrm{~mm}$. in length, rounded at base and apex, the apex, if anything, being slightly narrower than the base. The shell is very thin, the colour greenish or greenish-yellow, when young sometimes marked with red; the texture granular, without any pubescence, but covered with minute liquid-bearing vesicles.

Common.

Germany, Austria, Switzerland.

\section{Dryophanta disticha.}

\section{Pl. II, fig. 3.}

Cynips disticha, Htg., Germs. Zeits., ii, 188; Schenck, Nass. Cyn., 58.

Aphilothrix disticha, Mayr, Eichengallen, 38, pl. $\nabla$, fig. 53.

Andricus disticha, Mayr, Eur. Cyn., 37.

A species not easily separated from divisa, but normally sized examples may usually be known by the mesonotum in front being less strongly pilose and smoother; the mesopleuræ bear punctures and with a large, smooth, and bare spot in the middle.

Gall.-Semicircular at the top, a little longer than wide, and nearly as high as it is long; pale yellow, smooth; at bottom narrowed towards the centre 
which is depressed, the depression having a raised point by means of which it is attached to the leaf; above there is a semicircular depression, with an elongated elevation in its middle. Length $5-6 \mathrm{~mm}$.; width $3-4 \mathrm{~mm}$; height $4 \mathrm{~mm}$.

Inquilines.-Synergus pallicornis, S. allipes, and, if Brischke be correct, $S$. thaumacer'a.

Parasites.-Syntomaspis cyaneus, S. regius, Eurytoma setigera, Mayr ; E. rosæ. Kirchner records Siphonura Schmidti, Rtz., and S. brevicaudis, Rtz.; Brischke, Syntomaspis caudatus, Torymus abdominalis, T. auratus, Decatoma biguttata, Eurytoma signata, Pteromalus Saxesenii, Mesopolobus fasciiventris, Torymus variolosus, Olinx gallarum, and Torymus abbreviatus, Boh. (= chloromerus, Wlk.).

Rare.

Germany, Austria, Switzerland.

\section{Genus Neuro'terus.}

Neuroterus, Htg., Germ. Zeits., ii, p. 135 ; Mayr, Eur. Cyn., p. 37.

Spathegaster, Htg., l. c., 186.

Ameristus, Foerster, Verh. z.-b. Ges. Wien, 1869, 333.

Manderstjernia, Radoszkowsky, Bull. Mosc., 1866, хxxix, 304, tab. ix, fig. 4 .

Scutellum not separated from mesonotum by a suture. Antennæ, o 13-15-jointed, $\delta$ 15-jointed, in $q$ thickened towards the apex. Parapsidal furrows present, or more often incomplete. Cheeks short, furrowed or not furrowed. Scutellar depression complete, angled, without a keel at its fore border, except indistinctly in apritinus. Abdomen lenticular, compressed, in $\delta$ petiolate. Wings with an elongated radial cellule, open at fore margin, but may be closed in apritinus ; hyaline or spotted with smoky patches, or entirely smoky: Claws simple or bifid. Antennæ and legs without depressed, longish, stiff hairs. Maxillary palpi 4-, labial 2-jointed.

In the agamic form the abdomen is longer, larger, and more compressed than in the sexual, the ovipositor being also longer (occupying the entire abdominal cavity) and more or less spiral (in laviusculis completely spiral), instead of being short and straight as in the summer brood. In colour the species are black, with lighter-coloured legs; red is never seen in Neuro-

VOL. Ir. 
terus, but through immaturity some of the specimens are brownish.

The galls of the agamic broods are flat, lenticular or button-shaped, and generally covered with hairs, and always found on the leaves, frequently in large numbers; the galls of the sexual summer brood are pea-shaped, soft, and succulent, as in baccarum and tricolor, sunk in the leaf, as in vesicatrix, or small and hard, as in albipes.

The genus is well marked by the absence of a suture between the scutellum and mesonotum. It contains eleven European species, and various species are known from North America.

\section{A. Parapsidal furrows distinct.}

\section{Neuroterus lenticularis.}

PI. III, figs. 1 (lenticularis) and 1 a (baccarum); Pl. XVI, figs. 4 (lenticularis) and 4 a (baccarum).

Cynips lenticularis, Olivier, Ent. Méth., vi, 281.

Neuroterus Malpighii, Htg., Germs. Zeits., ii, 192 ; Tasch., Hym. Deut., 137; Thoms., Opusc., 788, 21.

Neuroterus lenticularis, Adler, B. E. Z., xxi, 231 ; Zeits. wiss. Zool., 1880, 156, pl. x, fig. 1 ; Licht. Cyn., 7, pl. i, fig. 1 ; Mayr, Europ. Cyn., 39 ; Eichengallen, 45, pl. vi, fig. 63; Schenck, Beiträge, 67 and 106.

Cynips quercus-baccarum, Linn., S. N., ii, 917.

Spathegaster interruptor, Htg., 1. c., iii, 341 .

baccarum, Htg., l. c.; Tasch., Hym. Deut., 135 ; Marsh, E. M. M., iv, 125 and 225 ; Thoms., Opusc., 789 ; Zeits. wiss. Zool., 1880, 160, pl. x, fig. $1 a$; Licht., Cyn., 13, pl. i, fig. 1 a; Mayr, Europ. Cyn., 38 ; Eichengallen, 49, pl. vi, fig. 70); Schenck, Beiträge, 84 and 107.

For galls, see also Malpighi, Opera Omnia, pl. vii, fig. 15; Réaumur, Ins., iii, pl. xlii, figs. 8-10; Smith, Trans. Ent. Soc., 1839 ; Proc., p. 43.

Agamic Form.-Black, shining ; the antennæ brownish, the basal two or three joints of the flagellum yellowish; legs yellowish, more or less of the coxæ and base of femora blackish; wings hyaline, the first 
cubital cellule with a small fuscous cloud. Mesonotum shagreened, finely striated along the furrows. Ovipositor longer than the abdomen.

Length $2-5 \mathrm{~mm}$.

Easily known from the sexual form by the long curved ovipositor.

Gall.-More or less circular, usually pale yellow, sometimes brownish-red in colour; average diameter $4 \frac{1}{2} \mathrm{~mm}$.; flat beneath, with a minute knob by which it is attached to the leaf; above with the edges slightly curled up, and with a large conical elevation in the centre; the surface covered densely with radiating stellate hairs.

It is worthy of remark that the galls of this species found on the Turkey oak at Kew Gardens are always of a deep purple colour.

Inquilines.-Synergus Tscheli, Mayr, in April.

Parasites.-Torymus auratus, T. hibernans, Mayr; T. sodalis, Mayr; T. fuscicrux, Giraud; Syntomaspis caudata, Pteromalusdissectus, Wlk. (Giraud); and P.tibialis, West. (Giraud). Also Decatoma biguttata according to Brischke, Pezomachus gallarum, Giraud; Pleurotropis sosarmus (Fitch). Walker (Ent., vi, 504) records Eurytoma signata; and Ratzeburg, on the authority of Tischbein's rearings, Entedon flavomaculata and Megastigmus dorsalis.

As has been just stated, the sexual females lay their eggs in young oak leaves about the middle of June; the galls make their appearance in July, and fall to the earth in September or October. In the winter the galls swell up, becoming strongly convex; the larva grows, and in the natural state becomes a pupa and imago in March or April. The eggs are laid in the leaf-buds, the ovipositor being introduced at the top and inserted between the scales.

The number of galls found on a leaf is sometimes very great, exceeding 150 , and occasionally they occur in enormous numbers. When they do so the leaves become very distorted; and, owing to the galls being so closely packed together, they are very irregular in shape. 
The parasitic Torymus I have found as an external feeding larva on the Neuroterus in April; it lays its eggs in the galls in September.

Sexual Frorm.-Black; antennæ brownish, the basal 2-5 joints brownish or clear yellow; legs yellow, the coxæ at the base only or entirely black. Thorax and vertex opaque or semi-opaque, aciculated, especially on the lateral lobes of the mesonotum close to the furrows of the parapsides, where the aciculation becomes striated or wrinkled; the middle lobe more shining, but very slightly aciculated. Scutellum strongly wrinkled. Wings longish, broad at the apex, hyaline or subliyaline, a brown splash in first cubital cellule. Ovipositor short.

The $\delta$ has the third joint a little curved.

Length $2-2 \frac{1}{2} \mathrm{~mm}$.

The furrows of the mesonotum tend to become obsolete; the brown spot in the cubital cellule is not always present or clearly defined; the base of abdomen may be brownish, and the femora in the $\delta$ are occasionally suffused with fuscous.

Gall.-Berry-shaped or pea-shaped, spherical, smooth, soft, succulent, green with reddish cheeks, or entirely green; found on the under side of the leaf, in which case the attached base appears through the upper surface, or on the male catkins: The larval chamber surrounded by a whitish layer. The catkin galls generally smaller than the leaf ones. When the flies leave, the galls shrivel up, except those inhabited by inquilines. Diameter from 3 to $6 \mathrm{~mm}$. Found in May and early in June, the insects escaping at the middle of June.

Inquilines.-Synergus facialis, Htg., S. radiatus, Mayr, and S. albipes, all in the same year; likewise S. apicalis and S. ruficornis, according to Brischke.

Parasites.-Torymus abdominalis, T. incertus, T. regivs, T. auratus, Eurytoma rosæ, Eupelmus annulatus, Nees (Giraud); Pteromalus immaculatus, West. (Giraud); Tetrastichus atrocæruleus, Nees (Giraud).

According to Mr. C. G. Barrett, the Tortrix Sciaphila communana lives in the galls.

The galls being so soft and succulent, the development of the flies of necessity must proceed rapidly, or otherwise they would perish through the galls 
drying up or becoming rotten. By the middle of June most of the females have laid their eggs on the under side of tender and youngish leaves of the oak.

Widely distributed.

\section{Neuroterus punctatus.}

Spathegaster punctatus, Bignell, E. M. M., iii (2), 176.

"Black; legs flavous, upper side of hind coxæ, antennæ except the first two or three joints, which are lighter fuscous. Eyes not so large nor so prominent as those of baccarum. Thorax: the mesonotum trilobate, with deep furrows continued to the scutellum, where the punctures are very shallow, the sides closely punctured. Wings hyaline.

"Length $2.5 \mathrm{~mm}$.

"At first sight it has all the appearance of Spathegaster baccarum, but when closely examined the sculpture of the thorax separates it from that species, and the wings are free from fuscous clouds.

"In baccarum the mesosternum is separated from the mesonotum by a raised rounded ridge, much more prominent than that of the species now described, and the furrows on the mesonotum are much shallower and shorter (Bignell, l. c.)."

Bred by Mr. Bignell from oak buds which apparently were not expanded or distorted.

The inquiline is Saphylotus connatus.

Plymouth.

\section{NeURoterus FumipenNis.}

Pl. I, figs. 1 (tricolor) and 1 a (fumipennis); Pl. XVI, fig. 5 .

Neuroterus fumipennis, Htg., Germs. Zeits., ïi, 339; Tasch., Hym. Deut., 137; Mayr, Eichengallen, 45 , pl. ii, fig. 64 ; Europ. Cyn., 38 ; Thoms., Opusc., 789 ; Adler, B. E. Z., xxi, 232 ; Zeits. wiss. Zool., 1880, 164, pl. x, fig. 4 ; Licht., Cyn., 18 , pl. i, fig. 4 . 
Spathegaster tricolor, Htg., 1. c., 341 ; Schenck, Beiträge, 107 and 135; Mayr, Eichengallen, 49, pl. vi, fig. 71; Europ. Cyn., 38; Adler, Zeits. wiss. Znol., 1880, 165, pl. x, - varius, Schenck, Beiträge, 87 .

fig. $4 a$; Licht., Cyn., 19, pl. i, fig. $4 a$.

Agamic Form.-Black; antennæ brownish, the basal three joints and legs yellow; coxa generally brownish; wings hyaline, a brownish splash in first cubital cellule. Mesonotum finely and distinctly aciculated, striated or wrinkled at the sides, the centre less strongly shagreened and more shining; scutellum shagreened strongly and striated.

Length $2-2.8 \mathrm{~mm}$.

It is difficult to distinguish this species from numismatis; the mesonotum is, however, generally more strongly aciculated, the basal two joints of the antennæ are yellow, and the legs are usually of a much clearer yellow than in the other species.

Gall.-This gall resembles very closely that of lenticularis, from which it is not always easily recognised. It is smaller, never exceeding $3 \mathrm{~mm}$., is much redder in tint; the border is more distinctly curled up, the centre being thus more depressed, and instead of being gradually raised there, there is only a small knob-like elevation; the under side bears stellate hairs, but not so thickly as the upper side; and it is also darker on the lower side, being never whitish or yellowish as in lenticularis; and, lastly, it is much less gregarious.

The larva does not develop till April, being laterin its period of development than lenticularis and numismatis, the imago not appearing till May.

Inquiline.-Synergus Tscheki.

Parasite.-Torymus sodalis.

Sexual Form.-Black; the two basal joints of the antennæ clear brown, tegulæ light testaceous, legs yellowish-red, abdomen broadly yellowish at the base. Head and mesonotum acieulated, the middle lobe of mesonotum more shining, but slightly aciculated in some specimens. Scutellum rugose. Wings subhyaline at the base, the apex smoky ; a large smoky cloud at the end of the first cubital, and a smaller one at the end of radial cellules. $q$.

Length $2 \mathrm{~mm}$. 
The antennæ are often brownish towards the apex; the amount of yellow at the base of abdomen varies; the apex, too, may be yellowish, and the ovipositor is testaceous.

Gall.-Found in June and July on the under side of the leaves or on the leaf peduncle; small, roundish, whitish or pale yellow, covered with long, glistening, white bairs, which fall off at maturity; generally many occur on one leaf. Diameter $3 \mathrm{~mm}$.

It is a later species than baccarum, the flies not making their appearance before the middle of July. The gall, as well as that of fumipennis, is found on young shrubs or on the twigs growing at the foot of old oaks. With age the galls become bare, in which state they can hardly be known from those of baccarum. 'I'he central cavity is, however, longer in tricolor.

Inquilines. - Synergus albipes, Htg., S. facialis, Htg., and S. thaumacera, Dalm., all in June and July of the same year.

Parasites.-Eurytoma rosæ; and Mr. Rothera (Ent., $\mathrm{x}, 235)$ bred a Torymus and a Pteromalus from them.

Widely distributed in Europe.

\section{Neuroterus lateviusculis.}

Pl. I, figs. 2 (albipes) and 2 a (læviusculis).

Neuroterus læviusculis, Schenck, Beiträge, 70; Mayr, Eichengallen, 46, pl. vi, fig. 65 ; Europ. Cyn., 38 ; Adler, B. E. Z., xxi, 232 ; Z. wiss. Zool., 1880, 161, pl. x, fig. 2 ; Licht., Cyn., 14, pl. i, fig. 2.

Spathegaster albipes, Schenck, Beiträge, 85; Mayr, Eicnengallen, 50, pl. vi, fig. 72 ; Europ. Cyn., 39 ; Adler, B. E. Z., xxi, 232 ; Z. wiss. Zool., 1880, 162, pl. x. fig. $2 a$; Licht., Cyn., 15, pl. ii, fig. $2 a$.

Agamic Form.-Black; legs brownish or brownish-black, the apices of all the joints yellow, and sometimes more or less of the anterior tibiæ. Antennæ brownish-black, sometimes with the basal two joints yellowish beneath, the last two joints indistinctly separated. Head 
and thorax shining, vertex distinctly aciculated, mesonotum finely aciculated at the sides and indistinctly in the centre, which is strongly shining. Abdomen compressed laterally, subovate, elongated. Wings hyaline, immaculate.

Length 2-3 $\mathrm{mm}$.

The coloration of the legs is variable, some specimens having a greater amount of yellow on the tibix and femora than others. The subovate abdomen, which is longer than the head and thorax together, shining thorax, brownish legs, and immaculate wings serve to distinguish it from lenticularis and numismatis.

Gall.-In shape irregularly circular, often more or less incised, flat, bare, without stellate hairs; the colour green, greenish-yellow, or reddish; the sides sometimes raised or curled, the centre with a distinct small knob, this being sometimes surrounded by hairs. It is found on the under side of the leaf, and never occurs in great numbers on one leaf. Length $4 \mathrm{~mm}$.

From both lenticularis and fumipennis this gall is to be usually recognised by the surface being bare or but very sparsely haired. On the average it is smaller than lenticularis, from which it differs in the very distinct, clearly defined central knob, that of lenticularis not being anything so distinct. It is larger than fumipennis, and it is seldom that its border is so clearly curled up as in that form.

Inquiline.-Synergus Tscheli in April.

Parasites.-Torymus sodalis, T. hibernans.

Sexual Form.-Black, smooth, shining; the basal four or five joints of antennæ yellow, the rest often brownish or brownish-yellow, especially at the apex and on the under side; legs whitish-yellow, the coxæ, the greater part of femora, and sometimes the tibiæ brownish, seldom entirely whitish-yellow; ovipositor testaceous; wings hyaline, immaculate; nervures fuscous or pallid.

The $\delta$ has a trace of aciculation on the mesonotum; the third joint of the antennæ but slightly curved, the petiole generally short, otherwise as in $q$.

Length 1-1.7 $\mathrm{mm}$.

The smallest species, and easily known by the hyaline wings and white legs, more or less darkened on the coxæ and femora.

Gall.-Found on the edges of the leaves, the part 
where the gall is being contracted or incised. Length 1-2 mm., more or less oval, usually with a point at the apex; yellowish-white, smooth, sometimes slightly pilose.

The imago escapes in June, and, like the other Neuroteri, oviposits in the tender leaves.

Apart from its position on the leaf, I am unable to find any definite characters whereby the gall can be known from those of Andricus nudus and A.gemmatus.

Inquiline.-Synergus apicalis, Htg.

Common and of wide distribution, but not nearly so abundant as the common spangle gall (lenticularis).

\section{Neuroterus nUmisma'tis.}

Pl. III, figs. 2 (numismatis) and $2 a$ (vesicatrix); Pl. XVI, figs. 3 (numismatis) and 3 a (vesicatrix).

Cynips numismatis, Oliv., Enc. Meth., v, 787.

Neuroterus Reaumuri, Htg., Germs. Zeit., ii, 192 ; Schenck, Beiträge, 67 .

- $\quad$ numismatis, Mayr, Eichengallen, 44, pl. vi, fig. 62 ; Europ. Cyn., 39; Adler, D. E. Z., xxi, 232 ; Z. wiss. Zool., 1880, 163, pl. x, fig. 3; Licht., Cyn., 16, pl. i, fig. 3.

Spathegaster vesicatrix, Schlecht., Y B. Ver. Zwickau, 1871, 33; S. E. Z., 1870, 387 ; Mayr, Eichengallen, 51 , pl. vi, fig. 74; Europ. Cyn., 39 ; Adler, l. c., 163 , pl. $x$, fig. $3 a$; Licht., Cyn., pl. ii, fig. $3 a$.

Agamic Form.-Black; antennæ brownish-black, somewhat lighter at the base; legs brownish, brownish-yellow, or fuscous. Wings hyaline, a brownish spot at the base of the first cubital cellule. Mesonotum shining, especially in the centre; very finely aciculated; scutellum shagreened.

Length $2-2 \frac{1}{2} \mathrm{~mm}$.

Gall.-Round, averaging $2 \mathrm{~mm}$. in diameter, a large circular depression in the centre, the depression being wider than the sides; bare and reddish, the sides closely covered with golden, depressed, silky hairs. Found on the under side of the leaf, generally in numbers. 
This is commonly known as the "button gall."

These galls are found from July onwards. The imagos escape in April, and lay their eggs in the leafbuds.

Inquilines.-Synergus Tscheli, Mayr, in April.

Parasites. - Torymus fuscicrux, Giraud. Walker (Zool., iv, 145) records Callimome mutabilis, Platymesopus tibialis, Eurytoma curta, E. xthiops, Boh., Eupelmus urozonus; and Fitch (Ent., $\mathrm{x}, 69)$ Pleurotropis sosarmus.

Sexual Form.-Black; antennæ brownish, the second and the greater part of the third yellow; legs yellow; the coxæ, except at apex, and femora more or less black; the trochanters and hind tibiæ sometimes brownish. Wings hyaline, a very faint smoky cloud at end of first cubital cellule. Vertex aciculated; mesonotum smooth, shining, the parapsidal furrows generally obsolete; scutellum smooth, shining, scarcely aciculated.

Length 1:5-2 $\mathrm{mm}$.

Gall.-Irregularly semicircular or oval, $2-3 \mathrm{~mm}$, pale green; a swelling in the leaf, projecting from both sides; on the top in the centre is a small raised point, from which radiate to the circumference minute keels. The under surface bears no knob, nor has it distinct keels. It is raised on both sides hardly $\frac{1}{2} \mathrm{~mm}$. from the surface of the leaf. There is no inner gall, and the larva escapes by the upper side.

The gall is found at the end of May and in June, and the female oviposits in the tender leaves.

Common and of wide distribution.

\section{Neuroterus aprilinus.}

Pl. V, fig. 2.

Spathegaster aprilinus, Gir., Verh. z.-b. Ges. Wien, 1859, 363; Mayr, Eichengallen, 32, pl. iv, fig. 42; Europ. Cyn., 37; Adler, Z. wiss. Zool., 201, pl. x, fig. $19 a$; Licht., Cyn., 65 , pl. xi, fig. $19 a$; Beyerinck, Beob. u. d. ersten Entwickel. einiger Cynipiden Gallen, p. 138. 
Neuroterus Schlechtendali, Mayr, Eichengallen, 62; Schlechtendal, W.E.Z., 99-106; F. Loew, Verh. z.-b. Ges. Wien, 1884, 323 .

Black; the base of the legs brownish; the apex of femora broadly, the tibiæ and tarsi lemon-yellow; wings hyaline. Antennæ 14-jointed, thickish; the second joint thicker than long. The furrows on the cheeks distinct. Mesonotum shagreened; parapsidal furrows shallow, indistinct. Median segment with basal area bounded by circular keels. Claws simple. Radial cellnle often closed.

Length $2 \frac{1}{2} \mathrm{~mm}$.

The 14-jointed, stout antennæ, the second joint being thicker than long, and the simple claws, sufficiently distinguish this species.

The gall is found at the end of April or beginning of May in the terminal or axillary leaf-buds; on those buds, namely, whereof the leaves have not begun to grow. In form they are very variable, being conical, oval, or ovoid, and may at the apex terminate in a point. The colour when young is green or yellowish-green, and they may also be tinged with red; with age they become brownish. They are smooth and glabrous, thin-walled; internally contain one to five cells separated by thin walls, these cells being larger than common, so that the larva is not closely surrounded by the wall as is usual, but is able to move freely. Externally the cells are indicated by bulgings or by keels. The size is variable. The larger specimens project one-half or three-fourths out of the buds, but the smaller not if at all, the buds in this case being enlarged or distorted. With age they shrivel up.

They are found from the 15th April to the beginning of May, and grow to maturity very quickly, yielding up the insects within three days from the appearance of the galls.

I have unfortunately not had at hand a fresh specimen for figuring, and the dried galls are hardly characteristic of the fresh.

Mayr records Ceroptres arator as its inquiline, but suggests that it may really have issued from the twig 
gall of Andricus noduli. Mayr bred Platymesopus tibialis, Westw., from the galls.

There seems to be some doubt as to the agamic form of this species. Adler (Zeits. f. wissen. Zoologie, $\operatorname{xxxv}, 200$ ) suggested, from a certain resemblance and from the form of the ovipositor, that it was Neuroterus ostreus. Beyerinck, on the other hand (Beob. u. d. ersten Entwick. einiger Cynipiden Gallen, p. 138), relates that he has bred Neuroterus aprilinus from the galls of Andricus solitaria. Von Schlechtendal (l. c.), however, concludes from his observations that Neuroterus Schlechtendali, Mayr, is the agamic form, and this view is further confirmed by the observations of Dr. F. Loew. Again, there can be little doubt, as Mayr has shown, that ostreus, being an Andricus, can hardly be the agamic form of a Neuroterus.

Sexual Form.-Black, shining; mandibles, basal half of the antennæ and legs rufo-testaceous; the apical half of the antennæ, the femora and tibiæ infuscated; the coxæ fuscous; the antennæ 13-jointed; the second antennal joint ovate and equal in length to the first; the third a little longer than the fourth; the front, vertex, mesonotum, and abdomen polished and very shining; parapsidal furrows abbreviated or obsolete; scutellum punctate, rugulose, in front in the middle somewhat smooth (Mayr). $q$.

Length $0.9-1.1 \mathrm{~mm}$.

Mayr says that the thirteenth joint in some specimens appears to be composed of two amalgamated.

The gall is very small, and is found on the oak catkins in May. It is $1 \mathrm{~mm}$. in length, contracted at the base, dilated from a little below the middle through a stout keel, which proceeds from there to the top of the gall, where the keels become contracted. The part surrounded by the two keels is somewhat triangular. They are flattened laterally; when fresh, green and bare, becoming brownish with age. The part of the catkin from which they spring is dilated.

Not very common in England and Scotland, Germany, Austria. 


\section{B. Parapsidal furrows obsolete.}

\section{Neuroterus politus.}

Neuroterus politus, Htg., Germs. Zeit., ii, 193; iii, 339 ; Marshall, E. M. M., iv, 125.

"Minute, black ; mouth, base of the antennæ, and the legs dull testaceous, coxæ black at the base. Mesonotum smooth, shining, without sutural lines or punctures. Scutellum shining in the middle, opaque and punctured at the sides. Wings hyaline; the basal transverse vein, the subcostal, and the base of the radial cell brown, distinct, but not suffused; the areolet and other veins decolorous, obsolete. $q$.

"Var.-The femora and tibiæ more or less fuscous.

"Length $\frac{1}{2}$, alar exp. 2 lines.

"Several times taken on oak trees in Leicestershire" (Marshall, 1.c.).

The history of this species is unknown, and except by Marshall (1. c.) it has not been described or recorded by anyone since described by Hartig. I have never seen it myself. Neuroterus (Ameristus) parasiticus is said by Hartig to come out of the galls of Andricus globuli. 


\section{APPENDIX.}

I HAVE unfortunately very little to add of new information from Britain about the saw-flies; but since the publication of Volumes I and II great attention has been paid to them by several diligent students on the Continent. Brischke has added greatly to our knowlege of the life-histories of the T'enthredinides ; to von Stein we owe many excellent papers; while Pastor Konow has revolutionised the classification by creating a large number of new genera, besides limiting the older ones in conformity with these new ideas, after the analytical method now so prevalent.

\section{TENTHREDINIDES.}

So far as regards our species the only new genus erected by Konow is Rhogogastera, but he also has formed a genus Enearsioneura for Macrophya Sturmi, Klug. I have given Konow's definitions for our genera.

\section{Tentheedo (B. E. Z., xxvii, 236).}

Eyes strongly converging beneath, reaching to the base of the clypeus; frontal area distinct, furrowed down the centre. Antennal joints becoming attenuate towards the apex.

Our species belonging to Tenthredo as thus limited are- 
Tenthredo flava.

- livida.

- coryli.

- colon.

- solitaria.

- velox.

- rufiventris.

- balteata.

- Lachlanana.

- moniliata.

- dispar.

- scotica.

- atra.

- mandibularis.

- mesomela.

- obsoleta.

- olivacea.

- macula and bicincta are placed by Konow in Allantus.

\section{Tenthredo flava (Vol. I, p. 74).}

The larva of this species is described and figured by Brischke, p. 3, Taf. vii, fig. 9 . It feeds on Atgopodium podagraria. It is $22 \mathrm{~mm}$. long, of a beautiful bright reddish-brown colour, and has the dorsal vessel bordered on either side by a brown longitudinal line. At the base of each segment on either side of the dorsal vessel is a brown line proceeding backwards obliquely towards the feet. At the beginning of each segment are two darker lines which form a pointed angle, the apex of which is directed towards the legs, the lines to it from the back being darker than those from the feet to the back. The head is small, shortly pilose; the claws are brown. On each segment are two transverse rows of white tubercles. When young the ground colour is darker and greener. At the last moult it becomes smooth and brighter in tint. 


\section{'Ten'thliedo livida (Vol. I, p. 75).}

Brischke (1. c., 115) gives as the food plants of this species Viburnum opulus, Rosa, Salix caprea, Corylus avellana, Sorbus aucuparia, and Pteris aquilina; Lonicera, the food plant given by Kaltenbach, not being mentioned.

Brischke describes the larva as being light grey, the back light brown running into green or even olivegreen through being mottled by darker streaks and spots; it is transversely wrinkled, the dorsal vessel darker. On each segment are oblique stripes pointing posteriorly, joined by another stripe from the opposite direction; each segment has two transverse rows of warts, there being also warts in the lateral folds over the legs. These folds bear upon each segment two brown spots placed obliquely, and under these is another single spot. Head shining, shortly haired, and orangeyellow, the eye spots black.

At the last moult the larva becomes shining yellow, with black dorsal streak, from which runs obliquely a similarly coloured stripe. As usual it is quite smooth.

Tenthredo punctula, Kl., is not the of livida, but is a distinct species (cf. Stein, W. E. Z., 1884, 309).

\section{Tenthredo CORYLi (Vol. I, p. 77).}

$T$. biguttata is not the $\delta$ of this species, but $T$. intermedia, Klug.

\section{Tenthredo solitharia (Vol. I, p. 79).}

Brischke describes the larva (l. c., 116, pl. viii, fig. 4) as feeding on Sorbus aucuparia. It is $25 \mathrm{~mm}$. long, greyish-brown; the back is broadly dark brown, with a still darker dorsal vessel, from which runs backward obliquely a stripe on each segment. Each segment 
has further $2-3$ transverse rows of brown warts, ending in a short brown hair. Each segment (except the first three) has over the legs a brownish splash. The head is shining, with black eye spots; the claws are brown. At the last moult the larva is shining; the markings remain, but are brighter.

\section{Tenthredo velox (Vol. I, p. 80).}

The $\delta$ of this species is T. biguttata, Klug.

\section{Tenthredo Rufiventris (Vol. I, p. 81).}

A specimen of this species from Pitlochry in Perthshire has the pleuræ quite black; one from Plymouth has the pleuræ and sternum white, splashed with red, and the head white except above.

The larva is described by Brischke (1. c., 118, pl. viii, fig. 6). It feeds on Salix caprea, S. aurita, S. helix, Alnus glutinosa and A. incana, Spirxa ulmaria, and Pteris aquilina. It is $22 \mathrm{~mm}$. long, transversely wrinkled, light brown, the back of a darker brown with still darker reticulated markings. On each segment before the middle of the fore margin are stripes which proceed obliquely backwards, bordered by a lighter colour. Over the legs are scattered spots and points, and each segment has two rows of distinct white warts. Head reddish-brown, shining, shortly pilose, the top of a darker brown.

At the last moult it becomes shining, reddish-brown or brick-red, with two dark brown oblique stripes on each segment.

The eggs (in one case ten on a leaf) are placed in openings in the leaf. The young larvæ are like the old, but brighter coloured, and have a bright brown head.

VOL. IV. 


\section{Tenthredo baliteata (Vol. I, p. 83).}

The larva I have figured on Pl. XIII, fig. $3 a-d$, Vol. II, and it feeds on Pteris aquilina. It is $20 \mathrm{~mm}$. long, transversely wrinkled, the back and upper half of the sides dark green, the lower half of the sides of a lighter green; the head pale orange, with dark eyespots and antennæ. On each segment are two transverse rows of small warts. At the last moult it becomes entirely orange-red, smooth, and shining.

Found commonly in August and September.

\section{Tenthredo Lachlaniana (Vol. I, p. 84).}

Konow (D. E. Z., 1890, 254) quotes doubtfully $T$. pocilopus, Mosc., and P. poecila, Evers., as the $\delta$. The species has been taken at York (Wilson) and Headley Lane (Billups).

\section{Tenthredo dispar (Vol. I, p. 86).}

This is regarded by Konow (D. E. Z., 1890, p. 254) as a variety of atra.

\section{Tenthredo atra (Vol. I, p. 88).}

The references to the larva given by Rudow, Dours, and André are no doubt wrong; for its foodplants are given by Brischke (l. c., 114, pl. viii, fig. 2) as Lamium album and Mentha aquatica. He describes it as $20 \mathrm{~mm}$. long, transversely wrinkled, bright green, above with a clearer tint, through which the dorsal vessel shows as a dark stripe. Each segment except the last has two transverse rows of white spiny warts, the first row on each side of the dorsal vessel is com- 
posed of three, the second of four warts; the lateral folds over the legs bear also warts. The stigmas are light brown. Head shortly haired, the front and vertex opaque, marked with blackish points extending from the eyes to the base of the antennæ. Between the eyes is a brownish splash. The anal fold is velvety pilose; the claws are light brown. It feeds in July.

\section{Tenthredo nandibularis (Vol. I, p. 89).}

Brischke describes the larva (1. c., p. 113, Taf. vii, fig. 11). It is $22 \mathrm{~mm}$. long, transversely wrinkled, and shortly pilose. The ground colour is a bright grey, the back to the orange-coloured stigmas deep black. Each segment bears laterally a longish orangeyellow spot, the second and third segments having in addition in front an orange splash; the first segment has none. On the ground colour are small black spots, mostly three on each segment. The head is shining black, the lower half reddish-brown.

At the last moult the larva seems shorter, more cylindrical, shining blackish-brown ; the ventral surface and legs grey; the orange-coloured spots are darker.

The food-plants are Petasites officinalis and Tussilago farfara, on which it is found from August to October.

\section{Tenthredo mesomela (Vol. I, p. 93).}

Konow (D. E. Z., 1890, 254) sinks obsoleta, Klug, and arctica, Thoms., as varieties of this species. Brischke (l. c., 112, pl. vii, fig. 10) describes the larva, and his description differs from mine. The food-plants he gives as Polygonum persicaria and Arctium lappa. The colour of the larva is given as bright ash-green, and it is shortly and finely pilose. The back is dark brownish-grey, with some darker markings. On each 
segment is a bright grey bordered triangle, close to which is a darker spot. The back is mottled with many dark spots and streaks; on the end of these there is on each segment a darker shade, and there are likewise two transverse rows of white warts. In the clear colour on the sides of each segment is found a brownish stripe, besides many dots. Head shining black, shortly pilose; the face dark brown.

He says it is found in September and October.

\section{Tenteredo olivacea (Vol. I, p. 95).}

This species has been found at York by Mr. Wilson.

Rhogogastera (D. E. Z., xxviii, 338).

Eyes parallel or almost parallel with one another, not reaching to the base of the mandibles; vertex thick, much broader than long, the sutures distinct. Antennæ short, the third joint longer than the fourth. Humeral cellule in hind wings appendiculate. Blotch distinct.

\section{Tenthredo punotulata (Vol. I, p. 96).}

For the larva of this species I am indebted to $\mathrm{Mr}$. J. E. Fletcher, who found it on Corylus avellana, and I have had them figured on Pl. XIII, fig. 4, Vol. II. Brischke's figure and description do not agree with mine. He describes it (l. c., iii, pl. vii, fig. 8) as $20 \mathrm{~mm}$. long, cylindrical, transversely wrinkled, and bright grey, often varying into reddish; the back dirty dark green, and clearly separated by the white stigmal line; the stigmas themselves are black. On each segment are two transverse rows of white warts and many spots and dots; the dorsal vessel, frequently 
brighter margined, appears darker. At the base of the ventral legs is a brownish longitudinal streak, and over the thoracic legs is a broader stripe; the claws of the latter are brown. Head reddish-brown, shortly haired, shiny; eye-spots black; mandibles blackish.

At the last moult the larva becomes smooth, shining, yellowish-brown, the dorsal vessel bordered on each side by a brownish line. On the sides are on each segment many brown transverse streaks and points, whicb often form oblique lines, running from the back to the sides.

$\mathrm{He}$ says it is found from August to October on Salix caprea, Sorbus aucuparia, and Alnus incana.

\section{T.enthredo viridis (Vol. I, p. 97).}

The larvæ are described by Brischke (1. c., 110, pl. vii, fig. 7). He found them on Circra lutetiana, Stellaria holostea, Ranunculus repens, Salix helix, S. aurita, and Alnus incana. He says that the eggs are placed in a sheath $10 \mathrm{~mm}$. long, $1 \frac{1}{2} \mathrm{~mm}$. broad, divided into ten divisions, like the segments of a larva, in each of which is an egg. The full-grown larva is $15 \mathrm{~mm}$. in length, bright greenish-grey; the back to the black stigmas somewhat darker, mottled with brownish-black spots and points. The sides have some dark spots, usually a larger spot under the stigmas, and some small streaks and points upon the side pads at the base of the feet. On each segment are two transverse rows of white warts, between which stand minute white points. Head covered with short white hairs; at the eye-spots is a black mark, and there is a broader frontal spot between them. The orbital sutures suffused with reddish-brown. Antennæ moderately long. At the last moult the larva is smooth, without warts, transversely wrinkled and brick-red, and having on the back some transverse streaks. On the head only the eye-spots are black. 


\section{'Tenthredo gibbosa (Vol. I, p. 101).}

This should be called aucupariæ, Klug.

\section{Genus Tenthredopsis.}

This difficult and most variable genus has been revised by Pastor Konow (D. E. Z., xxviii, p. 306, et seq., and Revue d'Entomologie, ix). In the former work he renames the genus Thomsonia, but reverts to the original in his later papers.

He lays particular stress on the aid to be derived from the study of the $\delta$ genital organs :- "Organs extremely important to know the characters which constitute a species; but as it is very difficult for the author to describe these hidden organs of very small size, or for the reader to recognise the differences indicated, I have preferred, in constructing the analytical tables, to choose the characters visible exteriorly; but these characters, sometimes so variable, require a most careful attention to avoid being mistaken in using these tables" (Konow, Revue d'Ent. ix).

It is to be regretted that beyond the observations of Brischke recorded below nothing is known about the early stages of these variable insects. There can be no doubt that extensive rearings from the larvæ would throw great light on the specific distinctions of the insects.

Of T. brevispina, Thoms., he says that he found the larva on various species of grasses, on Juncus, Pimpinella saxifraga, Artemisia campestris, and Sarothamnus scoparius. They are $15-20 \mathrm{~mm}$. long, transversely wrinkled, bare, bright green, with two transverse rows of fine white warts on each segment. The bluishgreen back is bordered on each side with a fine white line, and over the stigmas and under the white dorsal 
line is a smaller darker stripe. Head shining, shortly haired; eye-spots black; antennæ and mandibles brown. At the last moult it becomes shining, grassgreen.

It is not very clear what this (brevispina, Brischke) species may be. Brischke says that not only did he breed T. brevispina from these larvæ, but also P. tiliæ, $\mathrm{Pz}$, and a $\delta^{\pi}$ of $P$. nassata; the latter being the nassata of Thoms. = cordata.

He further describes (1. c., 107, pl. vii, fig. 6) the larva of T. scutellaris, $\mathrm{Pz}$, as a feeder on Anthriscus sylvestris, Artemisia campestris, and on grasses in September and October. It is $15 \mathrm{~mm}$. long, becoming attenuate posteriorly, transversely wrinkled, with a comparatively large head. The ground colour is greyish-white. On the back is a brown central line; on each side of this is a line of light brown spots, then a line of smaller brown spots, followed by a clearly separated, broader, deep brown lateral stripe; on which, on segments $3-4$, are white warts arranged obliquely. Over the feet is a brown mark. Stigmas brown. The anal segment bears about five hairs, and has only the middle and the broad lateral stripe. Head shining, shortly haired, light brown, and bears the dorsal, the narrow, and the broad lateral body stripes. In front there are five lines converging to the centre, the oral region having a triangular line. Mandibles and claws brown. At the last moult it is shining without warts, with the dorsal stripe lighter and narrower, and the head without the dark markings.

Brischke says that sometimes the larvæ have green instead of brown markings.

Our species, on Konow's views, will now stand thus :

1. (2) Antennæ longer than the abdomen; spurs reaching to the middle of the abdomen; hypopygium very long.

T. cordata, Fourc.

2. (1) Antennæ not longer than the abdomen; spurs not reaching to the middle of the metatarsus; hypopygium moderate or small. 
3. (4) Pleuræ rugose, opaque; transverse radial nervure interstitial ; antennæ ringed with white. T. gynandromorpha, Rudow.

4. (3) Pleuræ not rugose, shining, smooth; radial nervure not interstitial; antennæ not ringed with white.

5. (6) Clypeus sharply incised. T. excisa, Th., and semirufa, Kriech.

6. (5) Clypeus truncated or only waved at the apex.

7. (11) Tegulæ white or pale.

8. (9) Body for the greater part yellowish.

9. (10) Body black, with the abdomen laterally fulvons.

T. Tividiventris, Cam.

10. (9) Body black, with the abdomen broadly red in the middle.

T. picticeps, Cam., flavomaculata, Cam. (? var. Raddatzi).

11. (7) Tegulæ black.

12. (13) Body black; abdomen bounded with red.

T. scutellaris, T. Coqueberti, F., T. nigronotata, Cam.

13. (14) Body black; abdomen entirely black, or with the sides laterally fulvous.

14. (13) Body rufous; head for the greater part black.

T. tristis, T. fulviceps.

T. nigriceps, Cam.

\section{TENTHREDOPSIS GYNANDROMORPHA.}

Tenthredo gynandromorpha, Rudow, S. E. Z., 1871, 390 .

Perineura gynandromorpha, André, Species, 416, 422; Cat., 53*.

Thomsonia gynandromorpha, Konow, D. E. Z., xxviii, 328.

Tenthredopsis gynandromorpha, Konow, Rev. d'Ent., ix, p. 68.

Black, shining; the 6-8 joints of the antennæ and scutellum white; the apex of the anterior femora and the anterior tibiæ and tarsi reddish-brown; the $3-7$ abdominal segments red; wings hyaline ; the base of the stigma white. Antennæ shorter than the abdomen; the apex of the clypeus with a shallow emargination, almost truncate; the head punctured, slightly dilated behind the eyes; the sutures on vertex shallow. Mesonotum with a distinct punctation; pleuræ coarsely rugosely punctured. Transverse radial nervure interstitial or nearly so; the second recurrent nervure at a distance from the transverse cubital. Spurs short. $q$.

Length $10 \mathrm{~mm}$.

The head in my specimen is entirely black; but, according to Konow, it may bear two small white spots.

A well-marked species from the coarsely punctured pleuræ and white ring on the antennæ.

One example from Clydesdale.

Continental distribution: Germany, Croatia, Spain (J. J. Walker). 


\section{Tenthredopsts cordata (Vol. I, p. 104).}

Konow unites this species (= nassata, Thoms.), microcephala, femoralis, and caliginosa into one species, which he names Thomsoni. If he is correct in this view it seems to me that no new name is required, but that the oldest name, namely, cordata, Four'c, should be used. He refers my o to Coqueberti (ignobilis), and in this he is correct.

The real $\delta$ of cordata (Thomsoni, Knw.) I have never seen. It is described by Konow as " rufescens, capite et mesonoto magis minusve albo et fusco-maculatis ; segmento ventrali late et semi-circulariter emarginato," the latter being a characteristic in which it differs from the other species, the males of which have the apex of the last ventral segment " rotundatum vel leniter emarginatum."

\section{Tenthredopsis nigronotata (Vol. I, p. 106).}

Konow doubtfully refers this species to his T. elegans (described in full, D. E. Z., xxx, 335), and I think the two are identical. He describes elegans, " minor gracilis, nigra; albo picta; pedibus et feminæ segmentis intermediis abdominis rufis ; tarsis posticis nigricantibus; capitis clypeo albido sulphureo ; antennis tenuibus, abdomen longitudine æquantibus. Mas : abdomine fere toto nigro, segmento secundo dense punctato, segmento ultimo ventrali apice rotundoto. Femina capite, pronoto, pectore, coxis uberius albomaculatis vel maxima parte nigris, cingulo rufo abdominis interdum linea dorsali nigra interrupto. " Long. 1112 mm."

There is no trace of white on the breast or pronotum on nigronotata, and only a small white spot on the hinder pronotum. The tarsi in elegans are described as dark, not distinctly lighter before the apex. The antennæ 
in nigronotata are of the length of the abdomen; the second recurrent nervure is interstitial.

Elegans is recorded from France, Germany, Switzerland, and Austria.

\section{Tenthredopsis ignobilis (Vol. I, p. 107).}

This is the $q$ of $T$. Coqueberti (which name it will bear), T. nigricollis, $q$ and $\delta$, being the same species. The form ignobilis has the hinder femora only black at the base and at the extreme apex. The of was described by Konow as T. Braunsii (D. E. Z., xxviii, 335). T. conjungens, Kriechbaumer, and T. limbilabris, Kriech, are also synonyms (cf. Regens. b. Corresp.Blatt., 1884, p. 17).

The $\delta$ of this species was, as has just been mentioned, referred by me to cordata. It is to be readily known. from the other males by the posterior wings not having a bordering nervure round the apex. There are two well-marked forms: one, the typical, with the legs (especially the hinder) for the greater part blackish, the other with them entirely reddish, except the $2-5$ hinder tarsal joints ; the other form having these joints white also. I have also seen specimens with the apex of the abdomen blackish, and another with a row of black dots down the side.

The T. ignobilis, Klug, is a true Tenthredo.

\section{Tenthredopsis Picticeps (Vol. I, p. 110).}

This species is probably, as Herr Konow himself suggests, T. dubia, Knw. The second transverse cubital nervure is interstitial ; the antennæ are nearly as long as the abdomen. 


\section{TenthreDopsis TRtstis (Vol. I, p. 111.)}

I cannot find that this species is described by Konow in his Revision. It appears to be related to his T. arrogans. The head is dilated behind the eyes, the tegulæ are black, the antennæ about as long as the abdomen, the apex of clypeus not quite transverse.

\section{Tenthredopsis ornata (Vol. I, p. 111).}

According to Konow there are two species of Tenthredopsis with incised clypeus allied to this, namely, stigma, F. = dorsalis, Spin., = histrio, Klug, and semirufa, Kriechbaumer (Regens. Corresp.-Blatt., 1884,15 . We have, I believe, the latter species.

T. semirufa is smaller than ornata ( $8 \mathrm{~mm}$. as against $10-14 \mathrm{~mm}$. for the latter); the antennæ are more slender, and as long as the abdomen; the second abdominal segment is only black in the middle, in ornata entirely black; the hind femora are broadly black at the apex, in ornata only very slightly, if at all ; the tibiæ are black at the apex, in ornata entirely red, and the coxæ are broadly lined with white. The arrangement of the white markings is the same in both species; the stigmas are white at the base; in semirufa the second recurrent nervure is received near the second transverse cubital; in both species there are two black lines on the ventral surface; ornata has the wings of a clearer hyaline colour.

According to Konow, T. dorsalis, Spin. (see vol. i, p. 111), is a synonym of T. stigma, Fab., = histrio, Klug, and ornata, Ändré, non Lep. In my opinion ornata, Lep., = excisa, Thoms.

The examples I have seen of ornata, Lep., have no black on the femora or tibiæ; but von Stein states that they are often entirely or partly black (cf. W. E. Z., 1884, 357). 


\section{Tenthredopsis fulviceps (Vol. I, p. 112).}

Konow (Revue d'Ent.,ix, 1890,p. 74)says, "Vraisemblablement la T. fulviceps, Cam., appartiendra à cette espèce"-that is to T. pavida, Lep., = Friesei, Knw. (D. E. Z., xxviii, 335), but he describes the antennæ as "longioribus" and "gracilibus" - terms which cannot well apply to the short (not longer than the abdomen), thick antennæ of fulviceps ; pavida, again, having the three middle segments of abdomen entirely ferruginous. No mention, either, is made of the broad fulvous band round the eyes found in fulviceps. In the latter the middle furrow on the vertex is deep and distinct.

\section{Tenthredopsis Lividiventris (Vol. I, p. 113).}

This species is not T. tessellata, Klug, as suggested by Konow, that species having the clypeus incised, while in lividiventris it is completely transverse.

\section{Tenthredopsis nigrioeps (Vol. I, p. 114).}

This differs from all the reddish species in having the tegula black, the thorax densely pubescent, and the mesopleuræ are finely but distinctly punctured.

\section{Thenthredopsts Saundersi (Vol. I, p. 114).}

This may be an extreme variety of T. Raddatzi.

\section{Tenthredopsis inornata (Vol. I, p. 116).}

This species is distinct from T. Raddatzi, particularly from the head being less developed behind the 
eyes. It is not T. nassata, L. sec. Konow, which has the spurs reaching to the middle of the metatarsus, this being not the case with inornata. In that species there is no furrow on the vertex in the middle, and the antennæ are thicker towards the middle; they are a little shorter than the abdomen. From dorsalis it may be known by the darker colour, wanting the whitish-yellow and shorter antennæ.

\section{Tenthredopsis nassata (Vol. I, p. 117).}

This is an exceedingly puzzling form. Thomson, as will have been seen, refers nassata, L., to cordata (described from the $\delta$ ), while Konow refers it to the yellowish species, but not that which I bave described. That he treats as a new species, which he names $T$. Raddatai (D. E. Z., xxviii, p. 334). Neither among my Continental nor British species can I find a specimen which I can identify as nassata, Knw. As regards Rarldatzi, there can, I think, be no doubt at all that the $o$ is exceedingly variable, and I should be inclined to place T. albomaculata, Saundersi, dorsivittata as forms of it. Furthermore, Konow (l. c., p. 81) describes a var. indocilis, " nigra, abdominis medio rufo, $q$ et $\delta$, pectus et mesonoti lobus medius nigris; lobis lateralibus interdum fusco-plagiatis," of which he says that it may belong to a distinct species; but inasmuch as he could not find any distinctive characters taken from the structure, he places them as varieties of Raddatizi. The same remark applies to $T$. flavomaculata, and T. picticeps may also be: an extreme form of Raddatzi. These two forms certainly agree with Raddatzi in having the tegulæ pale, a point in which they differ from our other black and red species.

The $\delta$ I have described is the right male of Raddatai, but I may point out that in most examples there is a V-shaped yellow mark on the mesonotum. This is probably the of Thomson has described under sordida. 


\section{Tenthredopsis sordida (Vol. I, p. 118).}

This is T. dorsalis, Lep. (Mon., 87, No. 252), according to Konow, and is not the sordida, Kl. The $q$ is tolerably constant, except in the amount of black on the abdomen. The $\delta$ is very variable; the legs may bear no black; the mesopleuræ are usually black, but may have white markings ; the mesonotum is, in most specimens, black, but may have a triangular white mark on the middle lobe, as in the $\delta$ of T. Raddatzi. The third abdominal segment is punctured, and the quantity of black on the abdomen varies.

It is not easy to distinguish the $\delta$ from that of Raddatai; but that usually may be separated by the larger size, reddish-yellow abdomen, by the greater expansion of white on the breast and pleuræ; by the sharp keel on the base of the abdomen, and by the interstitial second recurrent nervure.

T. sordida, Kl., nec Thoms., Cam., has the body of a lighter, whitish-yellow colour, and may be otherwise known by the ventral surface of the abdomen having on each side a black longitudinal line. I have never seen a British example of it.

\section{Genus Paghyprotasis.}

\section{P. simulans (Vol. I, p. 123).}

Brischke (1. c., 97, pl. vi, fig. 12) describes and figures the larva, and, as his description differs from that given by Kaltenbach, I reproduce it. $\mathrm{He}$ found it on Solidago virgaurea. In length $16-17 \mathrm{~mm}$; cylindrical, transversely wrinkled, except on the last segment. Body a bright bluish-green or bright green, the wrinkles with a bluish-white powder, and the sides have a stripe of a bluish-green colour. Head bright brownish, somewhat shining, but mostly whitish 
pruinose: There is a brownish dash over the black eye-spots, and there is a darker vertical spot. Stigmas small, black, the stigmal line white. Legs somewhat brownish. At the last moult the larva is shining, uniformly yellowish-green.

Brischke, it may be added, quotes simulans, Kl., as a synonym of lævicollis, Thoms.

\section{Genus Allantus (Vol. I, p. 139).}

Konow's definition of Allantus is, inter alia "antennæ before the apex more or less distinctly thickened. Vertex on each side over the antennæ truncated or slightly emarginate, and between the antennæ not or very little furrowed."

\section{Allantus scropholarie (Vol. I, p. 141).}

Konow (D. E. Z., 1890, 253) regards A. propinqua, $\mathrm{Kl}$., as a good species, and not a variety of the above.

\section{Allantus tricinctus (Vol. I, p. 143).}

This should be called A. vespa, Rtz. (Degeer, 72), this being the earliest name.

\section{Aliantus QUADRICINOTUS (Vol. I, p. 144).}

This is the true zona, Klug (Berl. Mag., 1818, 136) (nec Thoms.), which name it will have to bear, as it is very doubtful if it is the same as Uddman's species.

\section{Aliantus cingulum (Vol. I, p. 152).}

All the examples I have seen are, in my opinion, referable to cingulum, Kl., the $\delta$ of which is the Ten- 
thredo bicincta, Fab. (Syst. Piez., 29, 3), and bence our species must be called Allantus bicinctus, Fab.

Kirby (List of Hymen., i, p. 238) adopts the name of virgata, Fourc. (Ent. Par. ii, p. 367, 12), for bicincta, Fab., as an earlier name, quoting cingulum, Kl., as a synonym, as also 4-cinctus, Thoms.; 'and states that the species appears in Stephens' Collection as A.zonula. 'The reference to 4-cinctus, Thoms., is an error. According to Kirby (l. c., p. 241), Stephens' type of $A$. fasciatus, Scop., = zonula, Kl., is A. cingulum.

According, then, to Kirby, A. fasciatus, Scop. (Ent. Carn., 278), is British, and not having a specimen for description, I reproduce Klug's. The base of the antennæ, clypeus, labrum, mandibles, palpi, the edge of the pronotum and tegulæ, the basal segment of abdomen above, the fifth segment entirely, and the eighth and ninth above, yellow. Legs yellow; the coxæ, the outer side of middle and the hinder femora, the apices of the tarsal joints, especially on the hinder, blackish. Spurs black. Wings hyaline; the nervures brown, the apical nervures paler. Stigma yellow, brownish at the apex.

Length 8-9 $\mathrm{mm}$.

It has the head and mesonotum smooth, shining.

\section{Altantus tenulus (Vol. I, p. 153).}

For "tenulus" read "temulus." It has been pointed out by Rogenhofer and von Dalia Torre* that the Tenthredo temula, Scop., is identical, not witb. Allantus Rossii, Pz., but with Tenthredo bicincta, Linné, nec Fab. ; and, as temulus has priority by three years over bicincta, the former name must be adopted.

For the Allantus temulus of this work the name of Rossii, Pz., must be used.

* Verh. z.-b. Ges. Wien, 1881, p. 595. 


\section{Allantus marginellus (Vol. I, p. 145).}

Von Stein has pointed out (Ent. Nacht., 1885, p. 115) that under the name of marginellus, Fab., two good species have been confounded, namely, marginellus, Fab., and omissus, Foerster (S. E. Z., 1844, p. 289) = viennensis, Pz. (he described it as the Tenthredo viennensis, Schrank, which is probably an $\mathrm{Em}$ phytus), marginellus, Thoms. = viennensis, André. All the examples I have in my collection are referable to omissus, which is to be known from marginellus = succinctus, Lep., by having the head and thorax opaque and strongly punctured.

\section{Genus Dolerus (Vol. I, p. 157).}

The species with oblong eyes, almost emarginate in the inner side, namely, palmatus, vestigialis, and pratorum, have been formed by Konow (D. E. Z., 1890,240 ) into a distinct genus, namely, Loderus, Konow.

\section{Dolerus palmatus (Vol. I, p. 161).}

Konow has separated the palmatus, Thoms., from the palmatus, Kl., as a new species, under the name of-

\section{Dolerdes TRIGEMinus. \\ D. E. Z., xxviii, 346.}

Our form belongs to it, and not to palmatus, $\mathrm{Kl}$., which differs from it in having the head contracted behind the eyes, the sheath of the saw before the apex not emarginate, and having a small tooth there; while the $\delta$ has only white on the first, fifth, and sixth abdominal segments; trigeminus having the head dilated

VOL. IV. 
behind the eyes, the sheath before the apex emarginate slightly and without a tooth, and the $\delta$ has white on the fourth to the sixth abdominal segments. Von Stein, however (Ent. Nacht., 1887, p. 170), sinks trigeminus as a variety of palmatus, $\mathrm{Kl}$., and in this view Konow himself (D. E. Z., 1890, p. 251) agrees.

\section{Dolerus triplioatus (Vol. I, p. 162).}

The $\delta$ of this species is D. tremulus, Kl. (Berl. Mag., viii, 228), and Konow and von Stein propose to use this as the specific name; but inasmuch as 3-plicatus was printed before tremulus I prefer to retain this designation.

The $\delta$ I have described differs from tremulus in having the thorax coloured like the $q, i$. e. yellow with three black marks, and the base of the abdomen is not black.

Whether the $\delta \mathrm{I}$ have described is a variety of the $\delta$ of triplicatus, or if it belongs to a new species, is a point which I cannot make out from the material at my command, but I can find nothing like it described.

\section{Dolerus lateritius (Vol. I, p. 163).}

Konow adopts the name of madidus for this species (D. E. Z., 1890, p. 251, and 1886, p. 79) ; lateritius, $\mathrm{Kl}$,, \& , being a composite form according to him, having madidus as $\delta$ for one part, and uliginosus, Kl., for the other. In the $q$ the polished space on the eighth abdominal segment occupies at least one half the length of the segment, while in uliginosus it is short and broadly triangular, and does not occupy more than one-third of it. D. Lamprechti, Knw. (D. E. Z., 1879, p. 341 ), is a synonym.

The larva as described by Brischke (l.c., 45, Taf. ii, fig. 7) feeds on Juncus glomeratus. It is $25 \mathrm{~mm}$. long, bright greenish-yellow on the ground colour, the back 
is broadly darker grey, on the sides with a darker border, the dorsal vessel being also darker. Stigmas brown, and over them is a black roundish spot, which is small on the first and last segments. Head bright reddish-brown, with an oblique black streak on each side on the vertex, there being another short one between the eye-spots. Antennæ conical, smooth, brown. It appears in August.

\section{Dolerds FULVIVEnTris (Vol. I, p. 164).}

Brischke (1. c., 44, Taf. ii, fig. 5) bred this species from a larva of which he did not know the food-plant. It was $20 \mathrm{~mm}$. long, grass-green in colour, transversely wrinkled, and finely shagreened. On the lateral pads are short needle-like hairs, these being also sparsely spread over the body. The dorsal vessel is darker, the stigmas small, brown, and placed on bright-coloured pads ; the last two segments have a brown lateral line. Head broader than long, and appears triangular when viewed laterally. It is shining but alutaceous, and in colour "bone-yellow ;" the vertex and a short streak on each side are light brown. Across the black eyespots is a blackish-brown oblique streak, and under is a lighter one contracted in the middle. The antennæ conical, bone-yellow; mouth brown. It was found at the end of August.

Von Stein (Ent. Nacht., 1884, p. 102) refers D. germanicus, Fab., to lateritius ; but if Konow be correct in making out lateritius, Kl., to be a composite species, I prefer to follow his nomenclature.

\section{Dolerus Palustris (Vol. I, p. 166).}

D. saxatilis, Htg. (Blattw., 233), is no doubt a variety; and, as stated above, uliginosus, which I quoted doubtfully as the $\delta$, is referred by Konow to lateritius, ex pt. 
The larva is figured, vol. ii, Pl. XIII, figs. 5 and $5 a$, on Juncus.

\section{Dolikus antious (Vol. I, p. 165).}

Our species appears to me to be the true anticus, Klug, and not brevicornis, Thoms., non Zad. = Thomsoni, Knw. (Hym. Sc., i, p. 288), as stated by Konow (D. E. Z., 1890, p. 251).

Dolerus dubids (Vol. I, p. 167).

D. timidus, Kl., is regarded by Konow (D. E. Z., 1890, p. 251) as a variety of this species.

Dolerus tinctipennis (Vol. I, p. 169).

This is not D. fumosus, Zad. (Besch. neuer oder wenig bekan., Blattw., p. 22 ; Konow, D. E. Z., 1879, p. 352), which is easily known from it by the vertex not being limited by furrows laterally.

\section{Dolerus coracinus (Vol. I, p. 174).}

Konow (D. E. Z., 1879, p. 346) tabulates three species with oval apex of the middle lobe of the mesonotum, namely, coracinus, Kl. = nitens, Zad.; anthracinus, Htg. = corrulescens, Htg., ơ ; and atricapillus, Htg., known to him only at that time from the $\delta$ sex. In his catalogue of the European saw-flies (D. E. Z., 1890, p. 251) he gives also these three, but with different names, to wit nitens, Zad. = coracinus, Htg., Cam., non Klug; coracinus, Kl. = coerulescens, Htg., $\delta^{\pi}$; and anthracinus, $\mathrm{Kl} .=$ atricapillus, Htg., $\delta^{\text {\% }}=$ brachygaster, Htg., $\$$. 
Our coracinus is certainly the coracinus of the earlier paper of Konow; whether the coracinus of Klug and Hartig are different is not very clear to me, but very possibly the two are distinct; e.g. Klug's species has the wings hyaline, Hartig's and mine hyaline suffused with brownish; the cenchri in Klug's are white, mine has them fuscous. Neither Klug nor Hartig describes the position of the transverse radial nervure. There can be no doubt about our species being nitens, Zad.

\section{Dolerus anthradinds (Vol. I, p. 175).}

This is probably the anthracinus of Konow's first paper, now apparently referred by him to coracinus, Klug. It can hardly be anthracinus, Htg., for that author states that it has the head almost bare, while our species has the head covered with white hair, and the tibial spurs pale brownish. It does not agree very well with the description of brachygaster, for the abdomen is longer than the head and thorax united, the colour is not bluish-black, the fore calcaria are not brownish-red, and the wings are not "dunkel." It is not coracinus, $\mathrm{Kl}$., for that is distinctly bluish. I am inclined to regard our form as a new species.

Under the name of Dolerus anthracinus, Kl., Brischke describes a larva which fed on Carex and grass. What the species may be seems doubtful ; the $\delta$ he describes is the $\delta$ of fissus, which he quotes as a synonym, as also leucobasis, Htg. He quotes Thomson's anthracinus as being the same, so it is very likely possilensis. The larva is 17 to $18 \mathrm{~mm}$. long, shining, transversely wrinkled, greenish-yellow, a green dorsal and lateral stripe. Head reddish-yellow, eye-spots black, mouth brown; stigmas black, and over the base of the legs and the lateral pads is a blackish splash. The anal segment is bordered with black, and on each side is a black spot. 


\section{Dolerus FISSUS (Vol. I, p. 176).}

The $\delta$ of this species is described by Thomson under anthracinus. Konow refers planatus, Htg., to hæmatodes, and he gives varispinus, Htg., non Thoms., as a synonym (D. E. Z., 1890, 251).

\section{Dolerus gonagra (Vol. I, p. 170).}

Brischke has described the larva of this species (l. c., 45, T. ii, fig. 6). It is $20 \mathrm{~mm}$. long, yellowishgreen; down the back is a darker dirty green line, and there is a broader similarly coloured line along the sides, the upper border of which is sharply defined. Legs with brown claws. Head shining; eye-spots black; the antennæ conical, brown. The younger larvæ have on the stripes and over the legs black streaks.

Brischke fed them on " grass" in June.

\section{Dolerds oblongus (Vol. I, p. 177).}

This is not, it appears to me, as quoted by Konow (D. E. Z., 1890, 251), brevicornis, Zad., as that has the thorax entirely punctured, while in oblongus the sides close to the wings and base of scutellum are very little punctured, and the abdomen is shining, instead of being, as in brevicornis, without lustre; nor are the calcaria "very stout, needle-like," of " unusual length," and "conical."

\section{Dolerus possilensis (Vol. I, p. 178)}

$=$ anthracinus, Thoms., non $\mathrm{Kl}$. = varispinus, $\mathrm{Knw}$., non Htg. = coruscans, Knw. (D. E. Z., 1890, p. 251), which name it will bear. 


\section{Dolerus VARISPINUs (Vol. I, p. 179).}

According to Konow, varispinus, Htg., non Thoms., is a variety of fissus. Our species, it appears to me, is D. leucopterus, Zad. (Beschr., 26), said by Konow to be $=$ picipes, Kl. (Berl. Mag., viii, 303). D. leucopterus, however, is said to have the cenchri white.

\section{Dolerus E'NEUS (Vol. I, p. 182).}

D. elongatus may be a large form of this.

\section{Genus Strongrlogaster (Vol. I, p. 185).}

Konow (D. E. Z., iv, p. 19) has split up Strongylogaster, Dbm., into three genera, as follows :

1. (4) Third antennal joint longer than the fourth.

2. (3) Antennæ slender, in the middle more or less thickened, the first joint often thicker than the second; the other joints short, conical, longer than broad. Stromboceras, g. nov.

3. (2) Antennæ stout, short, of equal thickness, the first joint scarcely thicker than the second, that very short, transverse.

Strongylogaster.

4. (1) The third antennal joint as long or shorter than the fourth; the antennæ filiform; the sheath of the saw at the apex trifid.

Trinax.

\section{STROMBOCERAS.}

To this is referred delicatulus.

$$
\text { Strongylogaster (Vol. I, p. 185). }
$$

Our species are filicis, cingulatus. 


\section{Trinax.}

The species are continua, Knw. = mixta, Thoms., Cam., non Klug; mixta, Kl., non Cam. = femoralis, Cam.; macula, Kl. ; Sharpi.

\section{Selandria aPerta (Vol. I, p. 199).}

The Selandria aperta, Htg., is identical with Selandria cinereipes, Kl., non Blennocampa cinereipes, Htg. (cf. Konow, D. E. Z., 1886, p. 81).

\section{Sfilandria Serva (Vol. I, p. 194).}

The larva is described by Brischke (1. c., 90, pl. vi, fig. 5), and by von Stein (Ent. Nacht., 1880, p. 251), but their descriptions do not quite agree. Brischke describes it as $18 \mathrm{~mm}$. in length, cylindrical, the thoracic segments somewhat thickened, transversely wrinkled, and bearing short conical white warts and short hairs. The ground colour is greenish-yellow, darker or lighter if the larvæ eat the leaves or the flowers. Head shiny, bright yellowish-brown. On the body are five longitudinal rows of black points, each segment, except the first and last two having five of these points. The points on the middle row are small, the two lateral rows have them larger, while the two rows over the legs have them still larger. Over the thoracic legs is a black spot. Between and behind the black eye-spots is a small black point; the antennæ and mouth are dark. At the last moult they become stouter, bright grass-green, paler at the sides, without the black points and warts, the skin regularly transversely wrinkled, the dorsal vessel appears as a fine yellow stripe; the head brownish-yellow, with 
black eye-spots. The food-plant is Ranunculus acris, on which the larvæ feed in June.

\section{Selandria stramineipes (Vol. I, p. 197).}

The larva is described by Brischke (l. c., 91, pl. vi, fig. 6). In length $15 \mathrm{~mm}$, cylindrical, somewhat thickened in front, finely transversely wrinkled, beautiful grass-green in colour, with the stigmas small and black. Head bright ochre-yellow with black eyespots, the legs with brownish claws. The young larvæ are similar, but more yellowish in tint. They feed on Pteris aquilina in July.

It will be seen that this larva resembles that of $S$. analis very closely, the chief distinction apparently being in the colour of the head.

\section{Taxonds agrordm (Vol. I, p. 201).}

The larva, according to Brischke (1. c., 93, pl. vi, fig. 7), is found on the raspberry (Rubus idæus). It is $18-19 \mathrm{~mm}$. long, cylindrical, narrowed towards the apex, and has many transverse wrinkles. The head is higher than broad; the front and vertex have short, the face longer hairs. Front and vertex bright brownish-yellow, dull, the face shining and more greenish in tint, eye-spots black, the antennæ short. Over the eyes is a dark brown spot, which is frosted like the entire upper part of the head with white, the mouth brown. The body is bright bluish-green, frosted with white transverse wrinkles, except that the last segment wants the latter. 'The dorsal vessel appears as a greenish stripe ; the stigmas are elliptical and brownish-red. At the last moult the larva becomes entirely bright green and shining. It appears in July. 


\section{Taxonus aquiseti (Vol. I, 202).}

Brischke (1. c., 93, pl. vi, fig. 8) gives Polygonum persicaria as the food-plant. According to Konow (D. E. Z., 1890, p. 250), T. sticticus, Kl., is distinct from equiseti.

\section{Taxonus glabralis (Vol. I, p. 204).}

As food-plants Brischke gives (l. c., 94, pl. vi, fig. 9) Polygonum persicaria and Lythrum salicaria.

\section{Taxonus Fletoheri (Vol. I, p. 205).}

Konow, in his Catalogue of European Tenthredinidæ (D. E. Z., 1890, p. 250), sinks this as a synonym of T. albipes, Thoms. I have not sufficient material at hand to offer a definite opinion on the matter.

\section{Taxonus glottianus (Vol. I, p. 206).}

This was described from a $q$.

\section{Pecilosoma pulveratum (Vol. I, p. 211).}

Von Stein (D. E. Z., 1889, p. 137) describes the $\delta$ of this species. It only differs from the $q$ in the colour being darker and its eye smaller.

\section{Pøcilosoma Fletcheri (Vol. I, p. 213).}

This is T. (Emphytus) immersa, Kl. (Berl. Mag., viii, 284) ; Emphytus immersus, Htg. (Blattw., 250).

Mr. Champion has taken it at Southampton. A 
specimen from Chertsey (Billups) has the femora of a much clearer reddish tint and without black, the white at the base of the tibiæ not so great, and the three apical segments have no white or luteous marks. The antennæ are shorter a little than the abdomen, thickish, the third and fourth joints subequal; abdomen with the segments largely marked with white on either side, the last segment with a triangular (A-shaped) depression; the femora and tibiæ reddish-yellow; the tibiæ fuscous, the joints white at the base.

\section{Pecilosoma guttatum (Vol. I, p. 215).}

Konow (D. E. Z., xxviii, p. 32) describes this species under the name of carbonaria, Knw., and 1. c., 1890, he gives guttatum, Thoms., as a synonym.

Guttatum, Fall., non Thoms., he refers to impressum, Kl., and submuticum, Thoms. There can be no doubt that the latter two are identical, but it also appears to me that impressum (as Klug himself suggests, Berl. Mag., viii, 113) is identical in all probability with carbonaria, Scop., Ent. Carn., 279, 733. This is also the opinion of Rogenhofer and von Dalla Torre (Vehr. z.-b. ges. Wien, 1881, 596), who say that the description and the fairly good figure agree with impressum.

As Fallin had mixed up two species under the name of guttatum, Thomson had the choice of applying the name to either of them, and I propose to retain his name, and for submuticum that of carbonarium, Scop.

\section{Eriocampa ofata (Vol. I, p. 221).}

Konow (D. E. Z., 1890, 250) reserves the name of Eriocampa for ovata, L., umbratica, Kl., and dorpatica, Knw.

For the other species he creates the genus- 


\section{Eriocampoides (D. E. Z., 1890, 239),}

which he defines thus:

Body short, ovate; head semispherical, not margined behind; eyes reaching to the base of the mandibles; antennæ attenuate at the apex, thickened at the middle; wings with two radial and four cubital cellules; transverse basal nervure inserted before the base of the cubital cellules ; first recurrent nerves not parallel; lanceolate cellule with an oblique nervure; claws with a tooth at the base.

'The chief point of distinction between them and Eriocampa is that in the latter the transverse basal nervure is received at the base of the cubital cellules, and is parallel with the transverse cubital nervures; while with Eriocampoides it is curved and received at a distance from the cubital cellules, as in Hoplocampa, \&c.

\section{Eriocampa annulipes (Vol. I, p. 222).}

The larvæ of this species I have found to be destructive to beech hedges, and Brischke (1. c., 84) found them feeding on Vaccinium myrtillus and V. uliginosum.

Eriocampa varipes (Vol. I, p. 223).

Brischke (l. c., 85) gives as the food-plants of the larvæ Populus tremula and Salix aurita.

\section{Eriocampa limacina (Vol. I, 224).}

An additional food-plant is Cydonia vulgaris (Brischke, l. c.). 


\section{Eriocampa ointia (Vol. I, p. 226).}

The shiny larva of this species lives on oaks.

Eriodaupa rosa (Vol. I, p. 227).

Konow (D. E. Z., 1886, p. 109) states that in Klug's collection in Berlin æthiops, Kl. (= rosæ), is represented by two of of Blennocampa cinereipes, Htg. (con$f(u s a)$, one o $B$. alternipes, one os B. confusa, three of Erioc. rose, a o Monophadnus, and a ot Monophadnus, and proposes that rosæ should be called æthiops. In my opinion less confusion will be caused by using the name rosæ. Moreover Fabricius is the original describer, not Klug.

\section{Genus Blennocampa (Vol. I, 229).}

Konow (D. E. Z., 1886, 183 et seq.) groups Blennocampa, sensu lat., with Fenusa, Fenella, and Mesoneura, into a tribe, and has further created several new "genera."

His classification is as follows :

1. The second recurrent nervure joined to the second transverse cubital or received in the second cubital cellule.

$1^{\prime}$. The second recurrent nervure received in the third cubital cellule.

2. Transverse median nervure of the posterior wings at the most interrupted at the apex of the first discoidal cellule, præsternum of the mesosternum, or only indistinctly indicated.

Mesoneura, Htg.

2'. Transverse median nervure of the posterior wing absent or only indicated at the base; præsternum of the mesosternum separated by a distinct furrow.

3. Eyes from the base. of the mandibles more or less distant. 4 .

3 . Cheek appendage linear or not present. 8.

4. Posterior wings of the $\delta$ surrounded by a bordering nervure; sheath of the $q$ (seen from the side) equally narrowed or more or less sharply pointed. 
4'. Posterior wings of the $\delta$ not bordered; sheath of the $q$ at the apex needle-like or rounded. 5 .

5. Claws simple; cheek appendages approximately of the length of the second antennal joint. Pareophora, g. n.

5 . Claws at the base with a (often very small) tooth; cheek appendage either only half the length of the second antennal joint, or even shorter.

6. Posterior wings with closed discoidal cellule.

6'. Posterior wings without closed discoidal cellule.

7. Third antennal joint at least one-third longer than the fourth; antennæ short and rather thick; sheath at the apex thorn-like, produced.

Ardis, g. n.

7'. Third antennal joint only as long as the fourth; antennæ slender and thin, almost filiform; sheath at the apex rounded.

Rhadinoceræa, g. n.

8. Third antennal joint shorter than the fourth. Phymatocera, Dbm.

$8^{\prime}$. Third antennal joint longer than the fourth.

9. Cubitus in the anterior wings not or very slightly angled, usually with four cubital cellules.

$9^{\prime}$. Cubitus at the commencement very strongly angled, and almost a right, at the apex a rounded angle forming; the first two cubital cellules united.

14.

10. The præsternum of the mesosternum separated by a distinct suture.

10'. Mesosternum without præsternum.

Tomostethus, g. n.

11.

11. Posterior wings without closed discoidal cellule, the third cubital nervure in a similar direction with the transverse radial, and is usually continuous with it.

11'. Posterior wings with closed discoidal cellule.

12. The front ocellus lies on the under half of a line which touches the upper border of both eyes.

12 . The front ocellus lies over this line.

12.

13. Blennocampa, Htg. Entodecta, g. n.

13. Posterior wings with a closed discoidal cellule, and with transverse median nervure.

13'. Posterior wings with two closed discoidal cellules and without transverse median nervure.

Pseudodineura, Knw.

14. Anal cellule in the hind wings absent; the humeral nervure in the fore-wings distinct, and bends against the brachial nervure, so that the lanceolate cellule appear's widely contracted.

Kaliosysphinga, Tischb.

14'. Anal cellule in the hind wings closed; the humeral nervure in the fore-wings absent or is straight.

15. Antennæ 9- or rarely 10 -jointed.

15'. Antennæ 11-14-jointed.

Fenusa, Leach. Fenella, West.

\section{Periclista.}

Konow, D. E. Z., 1886, i, 86.

Body ovate; eyes oblong, remote from the base of the mandibles; antennæ moderate, filiform, the third joint longer than the fourth, præsternum of meso- 
sternum not distinct, transverse basal nervure interstitial, claws bifid. Posterior wings with one discoidal cellule; the apical margin in the $\delta$ with a surrounding nervure. Sheath acuminate at apex.

To this section belong lineolata (i, p. 241) and melanocephala (p. 245).

\section{Bleinnocampa lineolata (Vol. I, p. 241).}

Our species is the true lineolata, Klug; B. pubescens, Zad., and B. albipennis, Zad. (which both belong to Periclista), being distinct from this and from one another.

\section{Pareophora.}

Konow, D. E. Z., 1886, 187.

Body short, ovate; eyes oblong, situated at a distance from the base of the mandibles; antennæ moderate, filiform, the third joint distinctly longer than the fourth; transverse basal nervure joined to cubital; posterior wings with one discoidal cellule; claws simple; sheath blunt at the apex.

\section{Blennocampa nigripes (Vol. I, p. 246).}

The $\delta$ of this species is $B$. luridiventris, Klug (Berl. Mag., viii, 104), and this name is adopted by Konow; but inasmuch as nigripes is placed before luridiventris in Klug's paper, and, further, as it is the best known name, I prefer to adopt it.

The larva of $B$. nigripes is described and figured by Brischke (1. c., 73, pl. viii, fig. 14). It feeds in July on Prunus spinosa, and is $10 \mathrm{~mm}$. in length, thickened at the thoracic region, and is rather darkish grey in colour and dull in tint; the eye-spots black. Each 
segment bears two rows of white cleft spines, there being eight longitudinal rows of these, while the first and last segments have longer simple spines, these spines being sharply differentiated from the darker ground colour. The small shining head is shortly pilose, the mouth brown.

\section{ARDIS.}

Konow, D. E. Z., 1886, 188.

Body elongate-ovate; eyes oblong, situated at a slight distance from the base of the mandibles. Antennæ short, thickish, slightly attenuate at the apex, the third joint not twice the length of the fourth ; the transverse basal nervure interstitial ; hind wings with one discoidal cellule, the sheath at the apex ending in a sharp point.

Our species are-

Blennocampa sulcata (Vol. I, p. 236).

bipunctata (Vol. I, p. 242).

Blennocampa bipunotata (Vol. I, p. 242).

Brischke (1. c., 74, Taf. iv, fig. 10) describes and figures the larva of what he calls B. bipunctata, Kl. It agrees exactly in description of the larva and its habits with the larva of Pocilosoma candidatum (vol. i, p. 210); and as Brischke quotes Selandria candidata, Voll., as a synonym, although a reference to Vollenlivoen's plate would have shown that his candidata was not a Blennocampa but a Poecilosoma, it looks as if some mistake had been made in the identification of the species. 
ToMosteThUS.

Konow, D. E. Z., 188, 214.

Body short, ovate, thickish; head wide, hardly narrower than the thorax; antennæ short, thick, pilose, the third joint almost double the length of the fourth; eyes reaching near to the base of the mandibles; transverse basal nervure received shortly before the base of the cubital; claws simple. Posterior wings with or without a discoidal cellule.

The species of this section are-

(a) With one discoidal cellule in hind wings : Blennocampa nigrita (Vol. I, p. 235).

$$
\text { - } \quad \begin{aligned}
& \text { micans (Vol. I, p. 237). } \\
& \text { fuscipennis (Vol. I, 247). }
\end{aligned}
$$

(b) With no discoidal cellule: Blennocampa fuliginosa (Vol. I, p. 249). ephippium (Vol. I, p. 248).

My B. micans not being Klug's (which is a Rhadmocera), I propose to call it brachycera.

\section{Blennocampa.}

Body ovate; head small, eyes reaching to the base of the mandibles or at a slight distance from them; antennæ moderate, thin, pilose, the third joint longer than the fourth, the third transverse cubital nervure interstitial, often parallel with the transverse radial; the third cubital cellule acutely angled on lower side; transverse median nervure received always long before the middle of first discoidal cellule ; hind wings without a discoidal cellule ; claws bifid.

Our species are-

Blennocampa assimilis (Vol. I, p. 256).

VOL. IV. pusilla (Vol. I, p. 253). 


\section{Blennocampa cinereipes (Vol. I, p. 249).

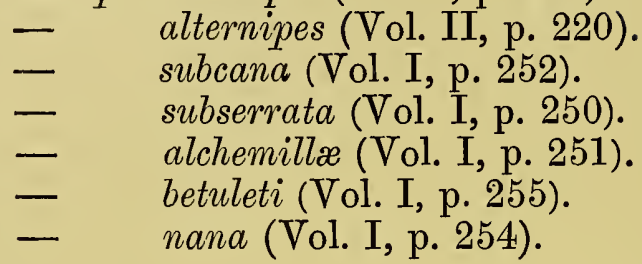

Blennodampa pusilla.

The third joint of the antennæ in this species is nearly twice the length of the fourth, and not as stated.

\section{Blennocampa alternipes.}

'This species agrees with pusilla in having the third antennal joint about twice the length of the fourth, while in confusa it is only half. It is Thomson's cinereipes.

\section{Bleinnodampa . CINEREIPES.}

Our species is the cinereipes, Htg., Konow, but not of Thomson, which $=$ alternipes. As has been already pointed out, the cinereipes, Kl., is a Selandria $=S$. aperta, Htg. B. cinereipes, Htg., has been renamed confusa by Konow (D. E. Z., xxx, 82).

\section{BlenNocampa ALCHEMILLIA.}

This is uncta, $\mathrm{Kl}$. and Thomson, and B. tenuicornis, Kl. (Berl. Mag., viii, 113), non Htg. It is described by Brischke as B. spiræx (l. c., 282). He found the larvæ on Spiræa ulmaria. 


\section{BlenNodampa aśsimilis.}

The larva feeds on Galium aparine in June. It is 13-14 $\mathrm{mm}$. long, rather rounded and cylindrical. The ground colour is bright greyish-green; the back bluish, always blending into the ground colour; and at the sides the ground colour is often of a yellow tint; before the last segments the blue is broken off by a clear space. The segments are covered with many small warts, each ending in a black microscopic hair. On the lateral folds over the legs are whitish bristles. The fore-legs are short and thick; the first joint is shining black, and the basal joint has a black plate. Head brown, shortly haired; on the vertex are two large black spots, and on the sides over the black eye-spots is a larger dark brown spot, there being also one on the face; the mouth dark brown. The young larvæ brighter; the dorsal stripe is smaller, and the head almost without the dark spots.

\section{Monophadnus.}

Body ovate; cheek appendages linear; antennæ moderate, the third joint longer than the fourth ; prosternum not distinct; the transverse radial nervure rarely interstitial; posterior wings with one closed discoidal cellule; claws bifid or simple.

\section{Blennocampa geniculata (Vol. I, p. 238).}

My description of the $\delta$ of this species was taken from bred specimens, which had the abdomen contracted, thus showing the antennæ to be longer in proportion to the body than they really are, they being, as I find from caught specimens, somewhat 
longer than the abdomen only. The anterior knees also are broadly white.

B. longicornis is a different species, it differing from $B$. geniculata, inter alia, in having the transverse radial nervure not interstitial.

\section{Blennocampa sericans (Vol. I, p. 233).}

According to Konowi, B. sericans, Htg., is an Ardis, having $B$. plana, Kl., for its $\delta$. Our species is a Monophadnus, Knw., and is Blennocampa elongata, Kl. (Berl. Mag., viii, 214). Hartig (Blattw., 269) made elongatus a Blennocampa, i.e. without a closed discoidal cellule in the hind wing, and in this he is followed by André, but Konow (D. E. Z., 1886, 245) makes it a Monophadnus, Knw. Konow (1. c., 188) states that in Klug's collection elongata is represented by two $\delta B$. alternipes, one $\delta B$. subcana, one $q$ to an unknown Monophadnus, one o B. sericans, Htg., and one $B$. elongata, $\mathrm{Kl}$.

$M$. elongatus is one of the largest species, and not difficult to recognise by the long abdomen, thickly covered towards the apex with long silky hair, by the bifid claws, by the short antennæ, and by the large antennal fovea with another round fovea on either side of it.

It has been taken by Mr. Wilson at York.

\section{- Blennocampa albipes (Vol. I, p. 240).}

Konow separates from albipes, Gml. rosarum, Brischke (l. c., 81, pl. v, fig. 5). Our species is not albipes, Gml., sec. Konow; but rosarum, Br. $=$ albipes, Thoms. (non $\mathrm{Knw}$.). B. emarginata, Thoms., is albipes, Gml., sec. Konow. See D. E. Z., 1886, p. 245.

The larva of rosarum is described by Brischke (l. c., 81, pl. v, fig. 6). It is $12-13 \mathrm{~mm}$. long, of a 
beautiful green colour ; the head shortly pilose, shining, often with a brown stripe from the vertex to the mouth. Claws brown; eyes black; antennæ conical, brown; mandibles brownish-red. Each segment has fine white transverse folds and two transverse rows of raised warts bearing reddish-brown spines. On the first and last segments stand somewhat brighter warts with two points, while the warts on the other segments have three. In every transverse row are six warts ; then follow still smaller spined warts, and the oblique skin folds over the legs have also spines. Usually the lateral folds bear 3-4 spines. The last segment bears two transverse rows of single thorns, and the border of the anal fold is likewise thorned. When young the larvæ are pale yellow, with white spines and bright brown head. Before the last moult the spines, \&c., are cast off.

It feeds on the young branches and young buds of the rose.

The description of the larva given on p. 240, Vol. I, refers of course to B. albipes, Gml., sec. Knw., of which I have not seen a British specimen.

Blennocampa nana and B. Betule't (Vol. I, pp. 254, $255)$.

In his revision (D. E. Z., 1886, p. 215) Konow places the above in Blennocampa, Knw.; but in D. E. Z., 1890 , p. 239, he creates a new genus-

\section{Soolioneura.}

Head small, ovate, eyes reaching to the base of the mandibles; antennæ slender, filiform; metasternal prosterna not often semi-distinct; the transverse basal nervure in front wings curved; the first recurrent not parallel; the transverse radial interstitial or not; the 
third cubital cellule with its posterior lower angle less acute; the hind wings without a closed cellule; the claws with a wide tooth close to the base.

He remarks that these two species cannot remain in Blennocampa owing to the striking length of the transverse basal nervure, and to the claws having a broad basal tooth, the true Blennocampæ having the claws cleft equally in two, the inner being more slender than the outer.

\section{Hoplocampa ferruginea (Vol. I, p. 259).}

According to Kirby (List of Hymen., i, 165) this is a synonym of Tenthredo apicaris, Fourc. (Ent. Par., ii, 376). If this be so apicaris is the earlier name, and should be adopted; but I am not at all satisfied as to this.

Brischke (l.c., 68) suspects that the larvæ live in unripe cherries.

\section{HOPLOCAMPA CRATAgI (Vol. I, p. 261).}

The larva, according to Brischke, lives in the unripe fruit of Cratægus. The young larva is shining, transversely wrinkled, with a large head; whitish-yellow, in the back reddish-brown. The thoracic legs above, the anal legs, the base of the claspers, the penultimate segment above, greyish. The very shining head is greyish-black; the face and mouth bright reddishyellow, the former with greyish shades; the apex of the sharp-toothed mandibles brownish-red; the eyes black; the antennæ conical. The full-fed larva is $5 \mathrm{~mm}$. long, brighter, the thoracic legs being also brighter ; the back reddish ; the head brownish-yellow ; the front, vertex and the hinder part of the head black; a brown spot on the face; the apex of the mandibles reddish-brown. Brischke says they have only twenty legs. 


\section{Hoplodampa rutiligornis (Vol. I, p. 263).}

According to Kirby (List of Hym., i, 167) this is fulvicornis, Panz., non Fab.

Emphytus togatus (Vol. I, p. 268).

Kirby (List of Hym., i, 196) refers this to Tenthredo ferruginosa, Gmel., Syst. Nat., i, pt. 5, p. 2667, n. 123 ; but this seems to me doubtful.

Emphytus Filicornis (Vol. I, p. 276).

The larva feeds on oaks, as related by Brischke (l. c., 51, pl. xi, fig. 12). It is $16-17 \mathrm{~mm}$. long, transversely wrinkled, cylindrical, clear bluish-green, dusted with white. The round head is shining and bright bluish ; behind the black eye-spots is a darker shade. Mouth reddish-brown. After the last moult the larva is a beautiful bright green, somewhat shining and with orange-coloured head. It is found in June; the flies appearing in September and October, like those of serotinus. Stephens must have been in error when he says he found them in June.

\section{Emphytus grossularia (Vol. I, p. 279).}

This is pallipes, Spinola (Ins. Lig., ii, p. 19), which is the earliest name.

Euphytus tener (Vol. I, p. 280).

Von Stein (Ent. Nacht., 1887, 210) has pointed out that T. tenera, Fall., is not the same as patellatus, Kl., 
for tener $a$ is stated to have all the tibir white and the wings "subnigricantes."

\section{Emphytus Perla (Vol. I, p. 281).}

Brischke describes the larva (1. c., 53, pl. ii, fig. 14). It is found in September on Salix triandra. It is 11-12 $\mathrm{mm}$. long, transversely wrinkled, the thoracic part thickened ; the ground colour of the almost transparent body is bright greenish-grey; the back is broad darker grey, generally running into the ground colour. The skin bears microscopic warts, giving it a rough appearance. The head is brownish-red, shining, shortly haired, the upper part to behind the black eyespots dark brownish-black.

This does not agree with Bouché's description.

\section{Genus Phyllotoma (Vol. I, p. 282).}

Konow (D. E. Z., 1890, p. 233) forms Phyllotoma, Heptamelus, Eriocampoides, and Hoplocampa into a sub-tribe, Hoplocampides, distinguished by the transverse basal nervure being received before the origin of the cubital and not parallel with the recurrent, and the lanceolate cellule not being appendiculate.

\section{$2 a$. Phyllotoma fumipennis.}

Cameron, E. M. M., 1888, p. 218.

Black, the abdomen above with various tints; the palpi, the labrum, the inner orbits of the eyes broadly, the tegulæ, a thin line on the base of the pronotum, the trochanters, the knees broadly, and the tibiæ beneath, white; the tibiæ above fuscous black; wings dark fuscous throughout, the tarsi blackish, paler at the junction of the joints; spurs pale; antennæ as long, as the abdomen, densely covered with pale pubescence, the apical joints brownish beneath; 12-jointed; the third joint one-half longer than the fourth. Head densely pilose; the pleuræ sparsely covered with longish whitish hair. Wings large, broad; the third cubital cellule dilated at the apex, as long as the first; the recurrent nervures received before the middle of the cellules.

Length $4.5 \mathrm{~mm}$. 
In the table given in Vol. I, p. 284, this species will come in as follows :

5 (2) Antennæ 12-13-jointed; wings for the greater part smoky.

$5 a$ (5b) Wings uniformly fuscous; tegulæ and a narrow line on the pronotum white; legs black, the trochanters, knees, and tibiæ beneath, white; abdomen ochreous above. Fumipennis.

$5 b$ (5a) Wings smoky, hyaline at the apex; tegulæ black; legs pale yellow, black at the base; abdomen not ochreous above.

Ochropoda.

P. fumipennis is a smaller and broader species than ochropoda, the abdomen especially being broader and not much longer than the head and thorax united; the head between the antennæ is broader, flatter, and does not project so much, the antennæ also being more widely separated.

Taken at Norwich on alder by Mr. J. B. Bridgman.

\section{Genus Fenusa (Vol. I, p. 290).}

As already (p. 173) indicated, Konow places Fenusa and Fenella among the Blennocampides, and separates Ulmi, Pumila, and Melanopoda from them into Kaliosyphinga, Tisch., the latter being distinguished from Fenusa and Fenella by " there being no anal cellule in the hind wings, and by the humeral nervure distinctly bending towards the brachial nervure, so that the lanceolate cellule appears widely contracted, Fenella and Fenusa having a closed anal cellule in the hinder wings, while the humeral nervure in the fore-wings is absent or straight. In Fenella (at least in nigrita and Westwoodi, the only species known to me from autopsy) there is no closed anal cellule in the hind wings.

\section{Fenusa quercîs (Vol. II, p. 222).}

Mr. Fletcher is now of opinion that he was in error in supposing that this insect mined the leaves of the 
oak, and that it was really an external feeding larva. It may be a Scolioneura.

\section{Fenusa pumilio (Vol. I, p. 298).}

This is referable to Konow's genus Entodecta, and is = to Blennocampa lanceolata, Thoms. (Hym. Scand., i, p. 211). Characteristic is the bend at the base of the transverse basal nervure, which joins the costa before reaching the cubital nervure.

The pumilio of Thomson is no doubt a different species, and has been named Fenusa Thomsoni by Konow (D. E. Z., 1886, p. 276).

Fenusa betula (Vol. I, p. 300).

This is nigricans, Klug, no doubt.

Fenusa holtulana (Vol. I, p. 296).

A specimen from Hayling Island (Billups) has the middle lobe of the mesonotum testaceous.

Fenusa hortulana has been taken at Chobham by Mr. Champion.

\section{Atealia ancilla (Vol. I, p. 306).}

It is doubtful if this is identical with A.glabricollis, Thoms., which name it had better retain.

Brischke (1. c., p. 67, pl. iv, fig. 2) describes the larvæ of $A$. scutellariæ under the name of rosæ. 


\section{Dineura verna (Vol. II, p. 16).}

As already (p. 173) indicated, this species is transferred by Konow from the Nematina to the Blennocampides, owing to the transverse basal nervure being received considerably in front, close to or interstitial with the transverse costal $=$ Mesoneura.

Konow has also formed for fuscula, parvula, and mentiens, Thoms., a new genus, Pseudodineura, distinguished from Mesoneura inter alia by the second cubital cellule receiving only one recurrent nervure, while in Mesoneura it receives both.

It is difficult to say in which cellule the recurrent nervures in despecta, Cam., are received, owing to the absence of the second transverse cubital nervure: in simulans from the position of the third transverse cubital and the second recurrent in the third cubital cellule, it very likely may be a Pseudodineura, and selandriiformis may be one also.

Konow places fuscula, Kl., in Pseudodineura, but if so, no great reliance can be placed on the position of the recurrent nervures, for Klug expressly states (Berl. Mag., viii, 71) that fuscula belongs to the few species which have two recurrent nervures in the second cubital cellule.

D. despecta, Htg., is placed by Konow in Mesoneura, and he further states that parvula, Thoms. = fuscula, Kl. Our species does not appear to be despecta, Htg., sec. Knw.; it agrees best with the description of par. vula, Thoms. Parvula, Klug, has hyaline wings.

\section{Cladius viminalis (Vol. II, p. 29).}

This species occurs in the United States of America, where it was discovered by Mr. Lintner, and named by him Aulacomerus lutescens (Fourth Report on the 
Injurious and other Insects of the State of New York, 1888, p. 45, figs. 20-22.

Aulacomerus has no relationship with Cladius.

\section{Cladius Brullati (Vol. II, p. 35).}

I have treated tristis, Zad., as a synonym of this species; and this is also the opinion of von Stein (Ent. Nacht., 1886, p. 27), who says that the typical examples he possesses differ in no ways from the specimens of Brullei he has bred from the raspberry and bramble feeding larvæ.

But Konow (D. E. Z., 1886, p. 75) states that the Rubus feeding larvæ are those of C. tener, Zad. I have re-examined my bred examples, as also those reared from the raspberry larvæ by Mr. Fletcher; and they do not agree with the description of tener; particularly in the latter having the wings "albis pellucidis," the tibiæ and tarsi "lutiscentibus," not "pallidis," while in tristis the wings are broadly fuscous or smoky in the middle. Konow himself states (l. c.) that tener easily distinguishes itself from tristis through its uncoloured wings, and also that it differs from it in the apex of the sheath being strongly triangularly widened at the apex, which is certainly not the case with our species.

The amount of fuscous or smoky tint in the wings varies, as it does also in intensity. Mr. Fletcher has bred a $\delta$ which has them uniformly subhyaline. The coxæ, too, may be white wholly or in part, and the apex of the coxæ may be white ; the tegulæ may be for the greater part testaceous. The frontal area is not indicated.

It is possible that Brullæi may be distinct from tristis, but I do not place much confidence in the white trochanters of Brullæi. Zaddach (Beob., 1883, p. 22) separates Brullæi from tristis by the wings and trochanters being white; tristis having the wings 
brownish coloured, and the trochanters black. Thomson, however, distinctly says of Brullæi, "alis basin versus pleurumque subfumatæ."

Brischke describes neither the larvæ of tener, Brullæi, nor tristis. For our species I propose to retain the name of tristis, because (supposing the two are identical) the imago of Brullæi was not described by Dahlbom; and Zaddach's description and name have priority over Thomson's.

\section{Nematus (Vol. II, p. 44).}

Konow has split up the old genus Nematus into ten. $\mathrm{He}$ includes in the tribe Nematina, besides these, Cladius and its sub-genera, Trichocampus and Priophorus, Eurra, Dineura, Hemichroa, and Camponiscus. His arrangement is as follows :

1. Lanceolate cellule in the middle widely constricted.

Lanceolate cellule petiolate.

2.

6.

2. The second and third cubital cellules each receiving a recurrent nervure.

The second cubital cellule receiving both recurrent nervures.

3. The third to fifth, sometimes also the sixth and seventh in the 5 . having a longer or shorter process; in the $q$ compressed, and terminating at the apex in a short process.

Antennal joints without process at the apex.

Cladius, Ill.

4. The third antennal joint at the base constricted underneath in the $\delta$, with a short, stumpy fork ; in the $q$ with a sharp edge.

Antennæ without any peculiarity.

5. With one radial cellule.

With two radial cellules.

Trichocampus, Htg. Priophorus, Latr. Camponiscus Newm.

Hemichroa, Steph.

6. With two radial cellules, the intercostal transverse nervure anastomosing behind the transver'se discoidal.

Dineura, Dbm.

With one radial cellule; the intercostal transverse nervure received before the transverse discoidal.

7. The apex of the clypeus more or less deeply emarginate 7. incised.

Clypeus transverse.

8. The second transverse cubital nervure absent.

The fore-wings with four cubital cellules.

9. The claws at the apex bifid.

Euura, Newm. it. 
10. The $\delta^{*}$, before the apex of the eighth dorsal segment, with a small, blunt, more or less awl-shaped process; the o with the antennæ towards the apex scarcely attenuated, almost filiform. Small flies of 3 to $5 \mathrm{~mm}$. in length; the stigma often pale at the base; the sheath of the saw often pointed posteriorly; gallmakers.

Pontania, Costa.

The eighth dorsal segment with the $\delta$ broad, bluntly triangular or hardly elongate before the apex; the antennæ towards the apex distinctly attenuated; the stigma never pale at the base; sheath never acuminate; the body larger.

11.

11. The last ventral segment at the apex bluntly triangularly elongated; sheath normal; the posterior legs simple. 12.

The last ventral segment of the $\delta$ at the apex emarginate, not incised; the sheath very broad, or the hinder tibiæ and tarsi thickened.

13.

12. Mesonotum and pleuræ shining; antennæ long and slender, usually paler beneath the head, seen from the front almost round; the labrum not longly projecting; the sheath usually very small and weak.

Pteronus, Jur.

Mesonotum and pleuræ opaque through a very fine and close puncturing; antennæ short, stout, sharply attenuated towards the apex; head more or less triangular, with a long projecting labrum; stigma posteriorly longly pointed; sheath thick and strong.

Amauronematus, Knw.

13. Hinder tibiæ at the apex and hinder tibiæ broadly widened.

Croesus, Leach.

Hinder tibiæ and tarsi weakly thickened or simple.

14.

14. Hinder tibiæ and tarsi thickened, the former longitudinally furrowed.

Holcocneme, Knw.

Hinder tibiæ and tarsi simple; the sheath very thick.

15. Hinder tibiæ and tarsi thickened.

Nematus, Jur.

Hinder legs simple.

16. Front with distinct pentagonal area.

Front convex without a pentagonal area.

14.

16.

Pachynematus, Knw. 18.

17. Pentagonal area more or less distinct; the last dorsal abdominal segment in the $\delta$ with a keel reaching to the apex; the sheath simple.

Lygæonematus, Knw.

Front concave, or with an indistinct pentagonal area; the keel on the last dorsal segment not reaching to the apex; the sheath broad, with distinct brush-plates.

18.

18. Clypeus transverse ; the first transverse cubital nervure absent or indistinct.

Pristiphora, Latr. Clypeus emarginate; the first transverse cubital nervure distinct.

Micronematus, Knw.

Nematus fulvipes (Vol. II, p. 56).

N. brevis, Htg., is treated by Konow as a distinct species from fulvipes. 


\section{Nematus abbreviatus (Vol. II, p. 60).}

Nematus abbreviatus is, according to Konow, a Micronematus; if so ours is a different species, differing from Micronematus in having the clypeus truncated and the first transverse cubital nervure obsolete. Our species is a Pristiphora. The pentagonal area is subdistinct; the claws have a subapical tooth. The length should be $5 \mathrm{~mm}$.

\section{Nematos hibernicus (Vol. LI, p. 58).}

Konow refers $N$. hibernicus to Micronematus; but it does not agree with the description of that section, inasmuch as my species has the first transverse cubital nervure very indistinct.

\section{1a. Nematus LaRicivorus.}

Nematus laricivorus, Zaddach, Schr. Ges. König, xxiv, p. 147, Taf. i, fig. $1 e$.

Black ; the labrum, palpi, tegulæ, the pronotum at the tegulæ, and the legs white; the coxæ broadly at the base, the four anterior femora at the base, the hinder almost wholly, the apex of the hind tibiæ, and the hind tarsi entirely, black ; the orbits in front narrowly brownish ; the antennæ fulvous, blackish on the upper side. Wings hyaline; the costa and stigma yellowish testaceous; the costa palest at the base; the stigma inclining to fuscous at the base. Antennæ as long as the thorax and abdomen united, densely pilose, slightly compressed; the 3-5 joints subequal. Head covered with short greyish pile, distinctly punctured; frontal area obsolete; clypeus transverse. Thorax shortly pilose, opaque, and punctured above; a fine keel down the middle lobe of the mesonotum; cenchri large, pallid. Abdomen shining, finely shagreened, the last segment above with an A-shaped impression in the centre, enclosing a raised, somewhat pear-shaped part; cerci longish. Legs covered with white pile; claws apparently simple. The first transverse cubital nervure is faint; the third cubital cellule a 
little wider than long; the second transverse cnbital nervure received about its own length in front of, the transverse basal nervure received a little in front of the middle of the cellule; the second cubital cellule has a horny point. $\delta$.

The $q$, according to Zaddach, has the antennæ black, the coxæ only black at the base, and the femora are less strongly marked with black.

Length $7 \mathrm{~mm}$.

The femora want the reddish tinge so conspicuous in the femora of appendiculatus; the vertex and front are much more strongly punctured, as is also the mesonotum; the hind tarsi are entirely black, and the apex of the hind tibiæ is more distinctly and uniformly so; the third cubital cellule is shorter, and is not dilated at the apex, and the pubescence is darker.

The larva feeds on Larix in August. It is $10 \mathrm{~mm}$. long, green, the dorsal vessel darker and bordered with white; over the legs is a white longitudinal line; the head shining, the eye-spots black.

Brischke says there.are two generations in the year. Plymouth (C. G. Bignell).

Prussia.

\section{Nematus oblongus (Vol. II, p. 69).}

In E. M. M., xxiii, 193, I have suggested that this may be identical with $N$. laricis, Htg. On re-examination $I$ am inclined to doubt this; in fact, from the obsolete pentagonal area, and from the shorter body form, I should be inclined to refer oblongus to Pristiphora rather than to Lygænematus, to which group Konow refers laricis. The first transverse cubital nervure is quite distinct. 


\section{Nematus molis (Vol. II, p. 74).}

Brischke (1. c., new series, vi, p. 2) bred this species from a smooth, bluish-green larva, transversely wrinkled, with a darker dorsal vessel bordered on either side with white, which fed at the end of June on Vaccinium myrtillus. I have noticed this larva at Rannoch, but failed to rear the imago.

\section{8a. Nematus crassicornis.}

Nematus crassicornis, Htg., Blattw., 204.

Black; the apex of the coxæ, the trochanters, the base and apical three-fourths of the four anterior fernora, the posterior femora at base and apex, the four anterior tarsi, the basal three-fourths of the hind tibiæ and the tegulæ white; the labrum brownish towards the apex. Wings hyaiine, somewhat suffused in the middle; the costa white; the stigma dark fuscous; the nervures fuscous. Head shining, shortly pilose, the front and vertex punctured, but not strongly; pentagonal area obsolete; the antennal fovea small; clypeus distinctly roundly but not deeply incised; the apex of labrum transverse. Palpi white towards the apex; thorax shortly but rather densely pilose; the mesonotum obsoletely punctured; cenchri clear white. Abdomen longer than the head and thorax united; the anal segment and cerci reddish; the latter short, thick, about three times longer than broad. Antennæ as long as the thorax and abdomen united, moderately stout, distinctly tapering towards the apex ; the third joint slightly curved beneath and a little longer than the fourth; the flagellum black above, reddishbrown beneath. First transverse cubital nervure almost obsolete; the second cubital with a horny point; the third cubital cellule about onefourth longer than broad, dilated towards the apex. Claws with a subapical tooth.

The $\delta$ has the antennæ thicker, the third joint distinctly curved, the flagellum entirely red. The last segment of the abdomen above projects in the middle, this middle part being raised and separated from the sides by furrows.

Length $7 \mathrm{~mm}$.,$+ 6 \mathrm{~mm} . \delta$.

I have seen several English examples of this species. Characteristic (for the group) is the incised clypeus. Germany. 


\section{0a. Nematus Pallipes.}

Tenthredo pallipes, Fallén, Acta Holm., 1808, 110, 48.

Nematus pallipes, Thomson, Hym. Sc., i, 97, 20.

Nematus carinatus, Htg., Blattw., 199, 28.

This species has been taken by Mr. C. G. Champion at Aviemore in Inverness-shire. It comes nearest to $N$. astutus and $N$. lativentris, but differs from both in the legs and stigma being yellowish-testaceous; the hind femora are only slightly lined with black; and in particular the apex of the middle lobe of the mesonotum is U-shaped, not V-shaped as in the other species. $N$. breadalbanensis is a narrower species than it; has the antennæ longer and thinner; the abdomen is longer; the femora and coxæ are broadly black; the rest of the legs whitish, not reddish-testaceous; the spurs are shorter, and the transverse basal nervure is received nearer the middle of the cellule. The keel on the mesonotum is indistinct, and there is also an indistinct keel on the scutellum in my example of pallipes. The third cubital cellule is longer and more dilated at the apex than it is in astutus, and the wings are of a much more decided fulvous tint.

Nematus careleucarpus (Vol. II, p. 82).

Konow refers vicinus, Lep., to crassus.

Nematus H出Morrhoidalis (Vol. II, p. 96).

Konow gives pallicerus, Htg., as a synonym; while, as will be seen (p. 99), I have treated it as identical with capreæ.

Nematus circumscriptus, Foer., is no doubt distinct from capreæ. 
Nematus turgidus (Vol. II, p. 103).

Konow reduces this as a synonym of $N$. brachynotus, Foer. (Vehr. ver. Rhein., ix, 295, pl. v, fig. 13).

Nematus canaliculatus (Vol. II, p. 106).

N. stenogaster, Foer. $=$ fullax, teste Konow.

Nematus stronaylogaster, Vol. II, p. 113).

Konow quotes doubtfully N. fuscomaculatus, Foer., and $N$. incompletus, Foer., as synonyms; but both differ in having the light colour whitish-yellow, especially on the head, whilst here it is brownish or testaceous.

\section{Nematus lactedos (Vol. II, p. 116).}

Kriechbaumer (C. B. Ver. Regenst., xxxiv, p. 110) has shown that this species is melanaspis, Htg. (S. E. Z., i, p. 27); and the species has also been described by Brischke and Zaddach under the name of $N$. sulphureus, Schr. Ges. König, xvi, pl. ii, fig. 14 ; l. c., xxiv, p. 337). Zaddach did not place it among the green Nemati.

\section{Nematus paliatus (Vol. II, p. 120).}

A synonym of this species is perhaps $N$. hypowanthus (cf. von Stein, Ent. Nacht., 1884, p. 352). 


\section{Nematus miliaris (Vol. II, p. 125).}

I have already (l. c., p. 116) indicated some doubt as to this being the true miliaris, $\mathrm{Pz}$. The first copy of Panzer's work I examined had the figure coloured more like our species than any other; but another copy had it coloured more like croceus, and a re-examination has convinced me that the name miliaris should be applied to croceus. Our miliaris is to be called microcercus, Thoms.

\section{Nematus tibialis (Vol. II, p. 130).}

Continental authors adopt the name of hortensis for this species; but inasmuch as Newman's description was published in January, and presumably before the appearance of Hartig's book, I consider that the name tibialis should apply.

\section{Nematus Consobrinus (Vol. II, p. 131.)}

Konow (D. E. Z., 1890, p. 245) refers umbrinus, Zad., to leucotrochus, Htg. ; but this is not the opinion of Zaddach himself, who referred it to consobrinus.

\section{Nematus conjugatus (Vol. II, p. 140).}

A synonym of this species is aurantiacus, Voll., non Htg.

Nematus V-flavum (Vol. II, p. 142).

This is a Nematus as limited by Konow, i.e. it belongs to the luteus group. The clypeus is not quite so sharply incised as in luteus. 


\section{Nematus croceus (Vol. II, p. 144).}

As already indicated, this should be called $N$. miliaris, $\mathrm{Pz}$.

\section{Nematus Cadderensis (Vol. II, p. 147).}

Konow in his catalogue sinks this as a synonym of N. miliaris (croceus); but the larvæ are so different, as will be seen by comparing my figure with the figures of miliaris, as given by Vollenhoven and Brischke, that I cannot accept this view.

\section{8a. Nematus fagi.}

Nematus fagi, Zaddach, Schr. Ges. König, xvi, Taf. v, fig. 1.

The imago of this species is not to be distinguished from miliaris (croceus) by any appreciable characters.

The larva is, however, so very different, that we may conclude that the two are quite distinct. It feeds on the beech, eating the leaves along the edges. It is green, shining, rather cylindrical, the dorsal vessel darker, the skin rough, and along the sides are irregularly arranged black points. Head shining, the vertex fuscous; eye-spots black. Found in July.

Sale, Cheshire.

\section{Nematus flavescens (Vol. II, p. 149).}

Our species is a Pteronus, while pallescens, Htg., is given by Konow as a Pachynematus with olivaceus, Thoms., and ruficeps, Zadd., as synonyms. Our species is certainly identical with varius, Brischke and Zaddach, and agrees perfectly, with a type I had 
from Zaddach under the name of dilutus. As Stephens' name is in any case the earliest, no change is required in the nomenclature beyond the excision of the name pallescens as synonym.

\section{Nema'tus glot'tianus (Vol. II, p. 148).}

Konow accepts my suggestion (l. c., p. 149) that this is identical with $N$. ferrugineus, Foer.

Nema'tus antennátus (Vol. II, p. 155).

Konow is no doubt correct in sinking this as a synonym of aurantiacus, Htg., non Cam., Thoms., Vollenhoven.

Nematus aurantiadus (Vol. II, p. 173).

This is not, as stated, aurantiacus, Htg. What it may be I am unable to say.

\section{Nematus albipennis (Vol. II, p. 175).}

Konow treats $N$. confusus as a distinct species from albipennis.

If Konow's views of the limits of the genera are to be accepted, our species will be arranged as follows :

Pristiphola.

Conjugata (Vol. II, p. 140).

Betulæ (Vol. II, p. 138).

Quercûs (Vol. II, p. 52).

Pallidiventris (Vol. II, p. 108).

Oblonga (Vol. II, p. 69).

Abbreviata (Vol. II, p. 60). 
Appendiculata (Vol. II, p. 66).

Fulvipes (Vol. II, p. 56).

Puncticeps (Vol. II, p. 59).

Crassicornis (Vol. IV, p. 193).

Ruficornis (Vol. II, p. 62).

Fletcheri (Vol. II, p. 65).

Laricivora (Vol. IV, p. 191).

Nigricollis (Vol. II, p. 66).

Funerula (Vol. II, p. 69).

\section{LYGEONEMATUS.}

Body elongated, ovate; clypeus truncated at the apex; pentagonal area more or less distinct; claws with a subapical tooth. The eighth abdominal segment in the $\delta$ keeled, the keel slightly produced at the apex. The saw-sheath simple.

Erichsoni (Vol. II, p. 50).

Ambiguus (Vol. II, p. 70).

Compressicornis (Vol. II, p. 55).

Lativentris (Vol. II, p. 78).

Leucopodius (Vol. II, p. 79).

Mollis (Vol. II, p. 74).

Breadalbanensis (Vol. II, p. 76).

Pallipes, Fall. (Vol. IV, p. 194).

Whitei (Vol. II, p. 75).

Fraternus (Vol. II, p. 73).

Scoticus (Vol. II, p. 72).

Astutus (Vol. II, p. 77).

Parvicornis (Vol. II, p. 80).

\section{Pachynematers.}

Body short, thickish; clypeus emarginate at the apex; the claw stout, armed with a subapical tooth ; the antennæ in the $\delta$ compressed, in $q$ shortish, 
subsetaceous, usually blackish. The eighth abdominal segment in the $\delta$ at the apex largely and widely, and the hypopygium subtriangularly produced. The sheath short, thickish.

Turgidus (Vol. II, p. 103). .

Capreæ (Vol. II, p. 99).

Rumicis (Vol. II, p. 179).

Imperfectus (Vol. II, p. 105).

Canaliculatus (Vol. II, p. 106).

Thomsoni (Vol. II, p. 87).

Clibrichensis (Vol. II, p. 88).

Apicalis (Vol. II, p. 89).

Leucogaster (Vol. II, p. 112).

Conductus (Vol. II, p. 111).

Obductus (Vol. II, p. 110).

Subbifidus (Vol. II, p. 139).

Albipennis (Vol. II, p. 175).

\section{Nematus.}

This includes only the ruficapillus group, namely:

Abdominalis (Vol. II, p. 153).

Ruficapillus (Vol. II, p. 158).

Aurantiacus (antennatus) (Vol. II, p. 155).

Bilineatus (Vol. II, p. 156).

Caledonicus (Vol. II, p. 159).

V-flavum (Vol. II, p. 142).

Acuminatus (Vol. II, p. 160).

\section{HoLCOCNEME.}

Body large; apex of clypeus emarginate; claws at apex bifid or with a subapical tooth; head and thorax strongly punctured and but little shining; stigma ovate at base, acuminate towards the apex, black; hinder tibiæ and tarsi thickened, the former grooved; 
the $\delta$ hypopygium at apex emarginate. Sheath small, thickish.

Crassa (Vol. II, p. 81).

Cœeruleocarpa (Vol. II, p. 82).

Lucida (Vol. II, p. 84).

\section{Amauronematus, Knw.}

Body large; the apex of the clypeus incised; claws bifid at the apex; antennæ short, substaceous, usually black; the stigma elongate, at the base ovate, the apex acuminate; head, mesonotum, and mesopleuræ finely and closely punctured, opaque; head subtriangular, the labium longly produced. Sheath thick, usually large.

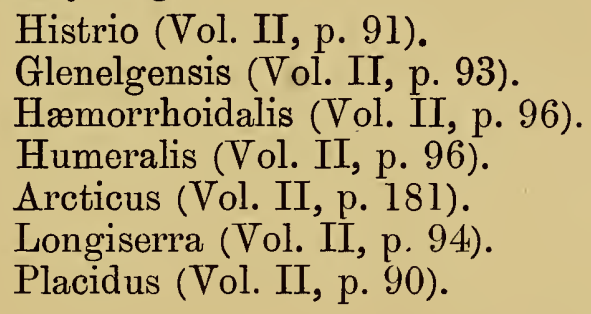

Pteronus, Jur.

Body large, hard; clypeus incised at the apex; claws bifid; antennæ long, almost always pale beneath; stigma of one colour; mesonotum and mesopleura shining, not sometimes sparsely punctured; head subrotund; labium not sometimes slightly. prominent. The eighth dorsal abdominal segment at the apex subtriangularly produced; the apex of the hypopygium narrow and subtruncately rounded. Sheath small, slim, the apex never acuminate.

$$
\begin{aligned}
& \text { Bipartitus (Vol. II, p. 176). } \\
& \text { Togatus (Vol. II, p. 184). } \\
& \text { Pavidus (Vol. II, p. 171). }
\end{aligned}
$$


Flavescens (Vol. II, p. 149).

Ferrugineus (glottianus) (Vol. II, p. 148).

Dorsatus (Vol. II, p. 151).

Fagi (Vol. IV, p. 197).

Miliaris (croceus) (Vol. II, p. 144).

Cadderensis (Vol. II, p. 147).

Bergmanni (Vol. II, p. 123).

Microcercus (miliaris) (Vol. II, p. 125).

Sylvestris (Vol. II, p. 124).

Glutinosæ (Vol. II, p. 126).

Salicivorus (Vol. II, p. 128).

Curtispina (Vol. II, p. 121).

Viridescens (Vol. II, p. 122).

Palliatus (Vol. II, p. 120).

Melanaspis, Htg. (lacteus) (Vol. II, p. 116).

Maculiger (Vol. II, p. 118).

Orbitalis (Vol. II, p. 119).

Zetterstedti (Vol. II, p. 135).

Pulchellus (Vol. II, p. 114).

Tibialis (Vol. II, p. 130).

Myosotidis (Vol. II, p. 133).

Monticola (Vol. II, p. 133).

Strongylogaster (Vol. II, p. 113).

Consobrinus (Vol. II, p. 131).

Ribesii (Vol. II, p. 168).

Collinus (Vol. II, p. 167).

Melanocephalus (Vol. II, p. 165).

Salicis (Vol. II, p. 163).

\section{Pon'tania.}

Body small, soft; clypeus incised at the apex; claws bifid at the apex; stigma usually of two colours. The eighth dorsal segment produced in the middle, narrow, obtuse, black. The of antennæ subfiliform; the sheath usually acuminate at the apex.

Leucosticta (Vol. II, p. 188).

Leucostigma (Vol. II, p. 190). 
Vacciniella (Vol. II, p. 191).

Albicarpus (Vol. II, p. 192).

Purpurea (Vol. II, p. 193).

Nigrolineata (Vol. II, p. 194).

Ischnocerus (Vol. II, p. 195).

Baccarum (Vol. II, p. 197).

Salicis-cinereæ (Vol. II, p. 198).

Bella (Vol. II, p. 200).

Curticornis (Vol. II, p. 202).

Gallicola (Vol. II, p. 202).

Herbaceæ (Vol. II, p. 205).

Bridgmani (Vol. II, p. 208).

Alienata (Vol. II, p. 207).

Crassispina (Vol. II, p. 207).

Vesicator (Vol. II, p. 183).

Xanthogaster (Vol. II, p. 177).

Scotaspis (Vol. II, p. 182).

\section{Selandria cinereipes (aPerta).}

Brischke (Schr. Natur. Ges. z. Danzig, vi, p. 5) found the larva of this species on Myosotis. It is $14 \mathrm{~mm}$. in length, dull, transversely wrinkled, with many raised warts on the sides, and raised protuberances on the somewhat thickened thoracic segments. The ground colour is bright grey, the back to the stigmal line blackish-grey merging into blue; the head and claws are black.

Brischke found the larvæ in October, apparently about to spin up.

\section{Pegolosoma gu'tratum.}

A larva found by Brischke on Viola tricolor and Polygonum yielded an imago which that entomologist doubtfully refers to $P$. guttatum. 
Emphytus tener (Vol. I, p. 280).

E. Olivier (Bull. Ent. Soc. Fr., 1890, lxxvii) describes the larva of this species as being very injurious to vines, through the of laying its eggs in the pruned twigs of the vines, the larvæ boring their way down the twigs, devouring as they do so the medullary canal, thus causing the branches to wither. The larva, according to Olivier, is of a beautiful delicate green colour.

It is obvious that in this country the larva must have some other food-plant than the vine. See Vol. I, p. 28l, for Stein's observations on its habits.

\section{Selandria serva (ante, p. 168).}

From a note by von Stein the larva described by Brischke under the name of Selandria serva is really that of Sciopteryx costatus (cf. Ent. Nacht., ix, p. 247).

\section{Aulax soabios 2 (ante, p. 51).}

As indicated, Aulax scabiosæ is recorded on the authority of Mr. E. A. Fitch. I had, however, overlooked a subsequent note of that gentleman (Ent., xii, 131) to the effect that, having sent the bred imago to Prof. Mayr, that authority reported that the species was not Aulax scabiosx, but a new species between A. scabiosæ and A. areolatus. The gall of A. scabiosæ is as figured (after Mayr), while the gall formed by the new species is monothalmous, and "consists of an irregular oviform swelling on the midrib, situate at the base of the leaf, where it shoots forth from the petiole; it is but slightly lighter in colour than the leaf 
itself, which it resembles in structure and in the amount of the pubescence" (Fitch, Ent., x, 125).

The fly has a well-defined areolet.

\section{Biorhiza terminalis.}

Besides some of the above-mentioned parasites Reinhard records Eupelmus Geeri, Dal., Syphonura variolosa, Ns., Pteromalus fascicularis, Foerst., $P$. naucus, Foerst., $P$. cynipis, L., Bracon immutator (S. E. Z., 1870, p. 386).

Common all over this country and on the Continent.

\section{Parthenogenesis.}

The only new case I have to record is that of Eriocampa annulipes. I induced virgin females to lay eggs, which produced males.

In Cheshire I have found this species to be injurious to beech hedges. 


\section{LIST OF FOOD-PLANTS.}

(See also Vol. I, pp. 32-41.)

Ranunculus acris.-Selandria serva, F.

- sceleratus.-Blennocampa ephippium.

- repens.-Tenthredo scalaris.

Hepatica triloba.-Dineura hepaticæ, $\mathrm{Br}$.

Stellaria holostea.-Tenthredo scalaris.

Tilia europæa.-Blennocampa tenuicornis, Kl. ; Nematus ruficornis.

Acer campestre.-Fenusa hortulana; Crœsus septentrionalis.

Lycopus europæus.-Athalia scutellariæ.

Prunus.-Hoplocampa ferruginea, Pz.; H. brevis, K. ; H. fulvicornis, Kl.; Blennocampa nigripes, Kl.; Nematus pruni, Zad.; N. cheilon, Zad.

Viola tricolor.-Selandria cinereipes.

Cratægus oxyacantha.-Hoplocampa cratægi; Nematus cratægi, Zad.;

N. Fletcheri, Cam.

Pyrus.-Cladius padi, Tenthredo punctulata, T. livida, T. fagi.

Rubus.-Blennocampa alternipes, Taxonus agrorum, Nematus flavicomus, Tischb.

Rosa.-Blennocampa rosarum, Br.; Eriocampa livonensis, Gim.; Tenthredo livida ; Cyphona gemmata.

Geum urbanum.-Fenusa Gei, Br.

Pimpinella saxifraga.-Tenthredopsis brevispina, Brischke; T. scutellaris.

Symphytum officinale.-Tenthredo procera, Kl.

Spiræa ulmaria.-Tenthredo rufiventris.

Mentha aquatica.-Pachyprotasis viridis ; Tenthredo atra.

Petasites.-Tenthredo mandibularis. T. procera.

Arctium lappa.-Tenthredo mesomela.

Artemisia campestris. -Tenthredopsis scutellaris; T. brevispina.

Solidago virgaurea.-Pachyprotasis rapæ; P. lævicollis.

Vaccinium myrtillus.-Eriocampa annulipes.

Lythrum salicaria.-Taxonus glabratus.

Lamium album.-Tenthredo atra.

Galium aparine.-Blennocampa assimilis.

Cydonia vulgaris. - Eriocampa limacina.

Polygonum.- Tenthredo mesomela, Taxonus equiseti, Pœcilosoma guttatum? (cf. Brischke, antea, p. 203).

Plantago.-Pachyprotasis viridis, $\mathrm{Br}$.

Populus tremula.-Eriocampa varipes, $\mathrm{Kl}$.; Nematus canaliculatus.

Salix. - Tenthredo rufiventris ; Emphytus perla, Kl. ; Pœcilosoma impressum; Harpiphorus lepidus ; Camponiscus aurita, Zad.; Nematus varius, Lep., Zad.; N. lævis, Zad.; N. vagus, Zad.; N. lucolenus, Zad.

Betula alba.-Pocilosoma candidatum, Fall. sec. Br.; Fenusa minima, Br. ; N. puncticeps ; N. dispar, Zad. ; N. pœeilonotus, Zad. 
Carpinus betulæ.-Crœsus Brischkei, Zad.

Alnus.-Tenthredo punctulata; T. rufiventris.

Fagus sylvatica.-Eriocampa annulipes.

Quercus robuv:-Emphytus apicalis, Kl.; E. tibialis, Pz.

Pinus, Larix, Abies, \&c.-Camponiscus ovatus, Zad.; Nematus laricivorus, Zad.; N. bufo, Br.; N. lariciphagus, Br.; N. Wesmaeli, Tisch.

Festuca.-Dolerus hæmatodus, D. cenchris.

Juncus.-Dolerus gonagra; D. lateritius; Tenthredopsis brevispina. Brischke.

Carex.-Dolerus anthracinus.

Pteris aquilina.-Tenthredo livida; T. rufiventris. 


\section{BIBLIOGRAPHY.}

List of the Principal Papers published in Journals and Transactions of Scientific Societies. For Titles of Complete Works see Vol. I, pp. 321-325.

Adler, $H$. Beiträge zur Naturgeschichte der Cynipiden. D. E. Z., 1877, 209-248.

- Lege-A pparat. und Eierlegen der Gallwespen. L. c., 305-332.

- Ueber den Generationswechsel der Eichengallen. Zeitschr. f. Wissen. Zool., xxxv, 1881, 151-246.

André, $E d m$. Notes Hymenopterologiques. Catalogue raisonné des Tenthredines reçueilles en Syrie et en Palestine en 1880 par Elzéar Abeille de Perrin, Ann. Soc. Ent. Fr., 1881, 333-362.

- Description de quelques Tenthrédines orientales inédites. L. c., $437-443$.

- Blennocampa melanopygia, Costa. L. c., 444-448.

Ascherson, $P$. Die springenden Tamarisken Frnchte und Eichengallen. Abb. Ver. Bremen, xii, 53-58.

Ashmead, W. H. On the Cynipidous Galls of Florida, and Descriptions of New Species. Proc. Ent. Soc. A. N. S., ix-xx, xxiv-xxviii, 1881 ; and 1885 , $x-$ xix.

- A Bibliographical and Synonymical Catalogue of the North American Cynipidæ, with Descriptions of New Species. Trans. Am. Ent. Soc., xii, 291-304.

- Synopsis of the North American Sub-families and Genera of Cynipidæ. L. c., xiii, 59,64 .

- On the Cynipidous Galls of Florida, with Descriptions of New Species and Synopsis of the Described Species of North America. Trans. Am. Ent. Soc., xiv, 125-158.

- On the Hymenoptera of Colorada (New Cynipidæ and Tenthredinidæ). Bull. Colorada Biol. Assoc., No. 1, 189.

Ballion, $E$. Ueber Tenthredo flavicornis und T. luteicornis. Bull. Mosc., $x \times x v, 441-448$.

Barnes, J. Ravages of Oak-galls. Gardener's Chronicle, 1868, 295.

Barrett, C. G. Note on the Lepidopterous Inquilines (in the galls of Andricus gemmæ, Biorhiza terminalis, and Cynips Kollari). E. M. M. iv, 153 . 
Bassett, H. F. On Dimorphism in the Cynipidæ. Proc. Ent. Soc. Phil., iii, 197; Proc. Ent. Soc., 1873, xv.

- Habits of certain Gall Insects of the Genus Cynips; Agamic Reproduction among the Cynipidæ. Proc. Am. Ass. Advancement of Science, xxvi, 302-306 (1877).

- List of the North American Cynipidæ. Am. Nat., xvi, 246.

- Arrangement of the North American Cynipidæ after Dr. Mayr. L. c., 1882,329 .

- Descriptions of several Supposed New Species of Cynips, with Remarks on the Formation of certain Galls. Proe. Ent. Soc. Phil., ii, 323-333.

- Descriptions of several New Species of Cynips and a New Species of Diastrophus. L. c., iii, 679-691.

- Galls found in Plants of the Genus Rubus. Can. Ent., ii, 98-100.

- New Species of Cynipidæ. L. c., xiii, 51-57, 75-79, 92-113.

- Description of a New Species of Cynips. Am. Nat., xv, 149.

- A Short Chapter in the History of the Cynipidous Gall-flies. Psyche, v, 235-238.

- New Species of North American Cynipidæ. Trans. Am. Ent. Soc., xvii, 59-92, 1890.

Bennet,, G. Description of a New Species of Saw-fly (Perga Eucalypti). Proc. Zool. Soc. London, 1859, 209.

- and Scott, A. W. Description of a Species of Perga or Saw-fly found feeding upon the Eucalyptus citriodora. Proc. Zool. Soc., 1859, 209, pl. lxii.

Beijerinck, $M . W$. Ein Beleg zu der von Dr. Adler entdeckten Heterogonie von Cynipiden. Zool. Anzeiger, 1880, 179; Ent. Nachr., 1880,45 .

- Over het cecidium van Nematus capreæ aan Salix amygdalina. Verl. A. K. Amst. (3), iii, 11-21; Arch. Neer., xxi, 475-492.

Berlese, A. Materiali per un Catalogo dei Tentredinei Italiani. Bull. Ent. Ital., xxi, 206-237; xxii, 144-202.

Bignell, G. C. Aphilothrix radicis, Synergus incrassatus. Ent., xiv, 166.

- A New Species of Cynipidæ. E. M. M., 1892, 176, 177.

Billups, T. R. Blennocampa aterrima. Ent., xx, 161. B. alternipes, l. c., 162.

Boheman, C. H. Spitsbergens Insekt Fauna. Oef., 1863, 563 (Nematus frigidus).

Boie, F. Entomolog. biologische Notizen. S. E. Z., 1848, 338 (Fenusa rubi).

- Beobachtungen und Bemerkungen. S. E. Z., 1855, 48-50.

Boisduval, J. A. Sur les ravages causés aux poiriers par la Tenthredo adumbrata, Kl. Ann. Soc. Ent. Fr. (4), vi.

Bold, T. J. Capture in Northumberland of a Saw-fly New to Britain (Strongylogaster filicis). E. M. M., x, 69.

Borries, $H$. Om Slaegten Ibalia, Latr. Ent. Med., iii, 53-57.

- Bidrag til Danske Insekters Biologi. Ent. Med., i, 199 (Phyllotoma aceris).

VOL, IV. 
Bosc, L. A. G. Sur un nouveau genre d'Insectes de l'ordre des Hyménoptères. Bull. d. Sc. par la Soc. Philomatique de Paris, 1818, 116 (Pinicola Julii).

Bouché, P. F. Bemerkungen über einige Blattwespen Larven. S. E. Z., $1846,289-291$.

- Ueber die Larve von Tenthredo (Nematus) capreæ in Beiträgen zur Kenntniss der Insectenlarven. S. E. Z., 1847, 164.

Bremi-Wolf, J. J. Beschreibung einiger Hymenopteren. S. E. Z., 1849, 92.

- Beiträge zu einer Monographie der Gallmücken. L. c., p. 64 (Cynips acerina $=$ Pediaspis sorbi).

Bridgman, J. B. Zaræa fasciata and its Parasite, Mesoleius sepulchralis. E. M. M., $\mathrm{xx}, 228$.

- The Fauna of Norfolk-Tenthredinidæ. Trans. Norwich Soc. Nat. Hist., iv, 524-536.

Brischke, G. Nematus helicinus, sp. nov. S. E. Z., 1850, 409.

- Die Pflanzen-Deformationen (Gallen) und ihre Erzeuger in Danzigs Umgebung. Schr. d. Naturg. Ges. zu Danzig, v.

- Nachtrag zu den Beobachtungen ueber die Blatt- und Holzwespen. Schr. d. Naturg. Ges. zu Danzig, vi (2).

- Ueber Parthenogenesis bei den Blattwespen. Schr. Ges. Danz., (2), vi, 168-172.

- Zweiter Nachtrag zu den Beobachtungen ueber die Blatt- und Holzwespen. L. c., vii.

- Einige für Westpreussen order überhaupt neue Ichneumoniden und Blattwespen. Schr. Ges. Danz. (2), vii, 102-107.

- and Zaddach. Beobachtungen ueber die Arten der Blatt. und Holzwespen. Sch. Phys. Oecon. Gesell. in Königsberg: Uimbicidæ, 1862, 204-78; Hylotomidæ, 1863, 83-124; Lydidæ, 1865, 104-202 ; Nematidæ, 1875, 23-89; 1882, 283-356; 1883, 121170. Schr. d. Naturg. Ges. in Danzig, 1883, 201-328.

Bronn. Lethra geognostica. Uebersicht der fossilen Pflanzen und Thiere (Hylotoma, Pteronus, Tenthredo, Cephites), 1850.

Brullé, A. Expédition scientifique de Morée, ii, part 1, 387-395, 1832. - Sur les Transformations du Cladius difformis. Ann. Soc. Ent. Fr., i, 308-311, pl. ii, figs. 10-12, 1832.

Burmeister, $H$. Athlophorus Klugii, ein neue Gattung der Blattwespen. In Jubelfeier der von 50 Jahren am 27 November, 1797, begangenen Promotion des Geb. Ober. Medic. Rath. Dr. Klug. Halle, 1847.

Cameron, Peter. Contributions to a Knowledge of the Scotch Cynipidæ. Trans. Glas. Soc. of Field Nat., ii, 44-51.

Note on Leaf-galls. Scot. Nat., i, 266.

- Tenthredinidæ in Rannoch. Scot. Nat., ii, 358.

- A New British Saw-fly, and on Crosus varus. Scot. Nat., ii, 274.

- Tenthredinidæ in the Glenelg Valley, Inverness-shire; Capture of Iyda erythrocera at Rannoch; Note on the Larvæ of Synergus; Biorhiza renum near Glasgow. Scot. Nat., ii, 62, 63 .

- Occurrence of Three New British Saw-flies in Scotland, Scot. Nat., ii, 16. 
Cameron, Peter (continued)-

- Memoirs on Tenthredinidæ. L. c., ii, 11-15, 113-116, 158-160, 196 -296 .

- On the Parasites and Inquilines of Nematus gallicola. Scot. Nat., ii, 111-116.

- On Saw-fly Larvæ and Ichneumons. Scot. Nat., ii, 111, 160.

- Note on the Larva of Synergus. Scot. Nat., ii, 111, 161.

- Nematus Wittewalli, a Saw-fly New to Britain. Scot. Nat., iii, 202.

- Tenthredinidæ in Braemar. Scot. Nat., iv, 10.

- Notes on Scotch Hymenoptera. Scot. Nat., iv, 11.

- Does Alternation of Generations or Dimorphism occur in European Cynipidæ? Scot. Nat., iv, 152.

- Occurrence of Pocilosoma pulveratum, Retz, a Saw-fly New to Britain. E. M. M., x, 69.

- Note on Camponiscus Healæi, Newman. E. M. M., x, 84.

- On the Occurrence of Cononeura Dahlbomi, Thoms., a Genus and Species of Tenthredinidæ New to Britain. E. M. M., x, 85 .

- Occurrence of the Galls of Cynips ferruginea, Htg. L. c., 85.

- Addition of Two Species to the British List of Tenthredinidæ. E. M. M., x, 160.

- Four Species of Nematus New to Britain. E. M. M., x, 211, 212.

-- Descriptions of Two Species of Tenthredinidæ New to Science from Scotland. E. M. M., x, 220-223.

- Additions to the British List of Tenthredinidæ. E. M. M., xi, 65.

- Notes on British Tenthredinidæ, with Description of a New Species of Nematus. E. M. M., xi, 107, 109.

- Description of a New Species of Eriocampa from Scotland with Note on a Variety of Taxonus equiseti, Fall. E. M. M., xi, 128, 129.

- Descriptions of Three New Species of Tenthredinidæ from Scotland. E. M. M., xii, 127-131.

- Descriptions of Five New or Little-known Species of British Tenthredinidæ. L. c., xii, 189-193.

- Notes on British Terebrant Hymenoptera. L. c., 226-228.

- On the Species of Nematus described in the Entomological Magazine. L. c., 228.

- Notes on British Tenthredinidæ, with Descriptions of Two New Species. E. M. M., xi, 250.

- Description of a New Species of Nematus from Corsica (N. Mar. shalli). E. M. M., xii, 9.

- Occurrence in Britain of Cladius Brullæi, Dahlbom. I. c., 42.

- Note on the Gall of Andricus radicis. L. c.

- Occurrence in Britain of the Galls of Nematus glandium, Gir. L. c., 83.

- Note on the Larva of Abia sericea, Linn. L. c., 111.

- Notes on British Tenthredinidæ and Cynipidæ. E. M. M., xiii, $173,196$.

- Notes on the British Species of Blennocampa. E. M. M., xiv, $55-58$.

- Description of a New Species of Nematus of the luteus-group from Sutherlandshire. E. M. M., xiv, 58, 59.

- Descriptions of New Genera and Species of Tenthredinidæ and Siricidæ, chiefly from the East Indies, in the Collection of the British Museum. Trans. Ent. Soc., 1876, 459-471. 
Cameron, Peter (continued)-

- Descriptions of New Genera and Species of East Indian Tenthredinidæ. Trans. Ent. Soc., 1877, 87-92.

- Note on Cladius Drewseni, Thoms. L. c.

- Notes on British Tenthredinidæ and Cynipidæ. E. M. M., xiii, $173-178,196-201$.

- On some New Genera and Species of Tenthredinidæ. Trans. Ent. Soc., 1878, 141-152.

- On the Larvæ of the Tenthredinidæ, with Special Reference to Protective Resemblance. Trans. Ent. Soc., xiv, 193-199.

- Notes on British Tenthredinidæ. E. M. M, xiv, 265-268.

- On Parthenogenesis in the Tenthredinidæ and Alternation of Generations in the Cynipidæ. E. M. M., xv, 12.

- On some New or Little-known British Hymenoptera. Trans. Ent. Soc., 1879, 107-119.

- Description of a New Species of Strongylogaster from Scotland. E. M. M., xvi, 63,64 .

- Further Notes on the Coloration of Saw-fly Larvæ. Trans. Ent. Soc., 1880, 71-76.

- Notes on Tenthredinidæ and Cynipidæ. E. M. M., xvi, 220-224, 247-250, 265-267; xvii, 66,67 .

- On Parthenogenesis in the Tenthredinidæ. L. c., 76-79.

- Description of a New Species of Dolerus (scoticus), from Scotland. E. M. M., I. c., 206.

- On Parthenogenesis in the Tenthredinidæ. E. M. M., l. c., 271.

- Notes on Hymenoptera, with Description of New Species (Tenthredinidæ). Trans. Ent. Soc., 1881, 563-576.

- Notes on Tenthredinidæ. E. M. M., xix, 132-135, 193-195, 271, 272 ; xxi, 26, 265-267.

- Descriptions of Ten New Species of Nematus from Britain. Trans. Ent. Soc., 1882, 531-540.

- On Parthenogenesis in the Tenthredinidæ. E. M. M., xxi, 103, 104.

- A New Species of Nematus from England. E. M. M., xxi, 80.

- A Synopsis of the British Species of Cimbecidina, Hylotomina, Lophyrina, Lydina. E. M. M., xxii, 47-51, 83-85, 117-123.

- Is the Genus Megalodontes (or Tarpa) really British? E. M. M., xxii, 164 .

- A Synopsis of the British Species of Cephina. E. M. M., xxii, $175-177$.

- Hymenopterological Notes. E. M. M., xxiii, 193-195.

- On some New or Little-known British Parasitic Cynipidæ. E. M. M., xxiv, 209-211.

- Description of a New Species of Phyllotoma (P. fumipennis), with Note on Nematus crassicornis, Htg. E. M. M., xxiv, 218, 219.

- Hymenopterological Notes-Notes on British Cynipidæ. E. M. M., $1890,313,314$.

- Synonymical Notes on Cynipidæ and Formicidæ. E. M. M., 1892, 67.

- List of Scottish Cynipidæ that form Galls on Oak. Scot. Nat., ii (2), $300-302$.

- Descriptions of Sixteen New Species of Parasitic Cynipidæ, chiefly from Scotland. Trans. Ent. Soc., 1883, 365-374.

- A Monograph of the British Species of Phænusa. Proc. Nat. Hist. Soc. Glas., 1876, 5-15.

- A Monograph of the British Species of Cladius, Illiger. L. c., 15-27.

- Addendum to Monograph of Phænusa. L. c., 95, 96. 
Cameron, Peter (continued)-

- Description of a New Species of Nematus from Scotland. L. c., $1876,260$.

- Notes on Hymenoptera observed in Inverness-shire. L. c., 1876, $290-294$.

- On the Habits of Nematus femoralis (Zaddach). I. c., 295-299.

- On the British Species of the Genus Croesus. L. c., 300-302.

- On some New or Little-known British Hymenoptera. L. c., $304-314$.

- A Monographic Revision of the British Species of Phyllotoma. L. c., $315-321$.

- Notes on Cynipidæ (Aulaæ graminis, n. s.). L. c., 321-324.

- On the Hymenoptera of Kingussie. L. c., 1876, 86-90.

- On a New Species of Blennocampa (B. alchemillæ), with Remarks on the Species allied thereto. L. c., 1876, 107-110.

- Observations on the Study of the Phytophagous Hymenoptera. L. c., $1877,141-152$.

- Notes on Clydesdale Hymenoptera. L. c., 201-207.

- A Contribution to the Hymenoptera of Sutherlandshire. L. c., 1878, $248-252$.

- On the Old-World Species of Athalia. L. c., 1877, 129-132.

- A New Species of Allantus (A. breviventris) from Salonica. Trans. Nat. Hist. Soc. Glas., 1885, 277, 278.

- On the Habits of Eurra (olim Cryptocampus). L. c., 1885, 38-41.

- On the Origin of the Forms of Galls. Trans. Nat. Hist. Soc. Glas., $\mathrm{v}, 1885,38-41$.

- On some Hymenoptera (chiefly undescribed) from Japan and the Pacific (Dolerus bimaculatus, D. Lewisii, Abia japonica, Abia Lewisii). Proc. Nat. Hist. Soc. Glas., i (2), 263-270.

- Biological Notes (Abundance of Galls of Neuroterus). L. c., $295-304$.

- On Parthenogenesis in the Hymenoptera. L. c. (n. s.), ii, 194201.

- Descriptions of Twenty-three New Species of Hymenoptera. Mem. Lit. and Phil. Soc. Man. (Selandria Rothneyi ex Bengal, Onychia striolata ex Bengal, Emphytus aztecus ex Mexico, and New Parasitic Cynipidæ ex Britain) (4), 159-183.

- On the British Species of Allotrinæ, with Descriptions of other New Species of Parasitic Cynipidæ. Mem. Lit. and Phil. Soc. Man. (4), ii, 53, 69.

- Hymenopterological Notices. Mem. Soc. Man. (4), iv, 182-194 (Hennedyia, gen. nov., Tenthredinidæ).

- Biologia Centrali Americana. Hymenoptera: i, Tenthredinidæ, 1-67; 1883, Cephidæ, 67 ; Siricidæ, 68, 69; Oryssidæ, 69, 70 ; Cynipidæ, $70-76$.

Capron, Ed. Tenthredinidæ at Shiere. $\quad$ E. M. M., xxii, 229.

Carpentier, $L$. Notes sur quelques larves des Tenthrédides (sic). Mém. Soc. L. N. Fr., vii, 65-69.

C. $D$. On the Ravages produced by Nematus capreæ. Loud. Mag., iii, 422-424, 1834 .

Chapman, T. A. Note on the Occurrence of Chalcidideous Larvæ on the Imago of Cynips [Biorhiza aptera]. E. M. M., iv, 13. 
Cockerell, T. D. A. The Evolution of Insect Galls. Ent., xxiii, 73.

Comstock, J. H. Locust Saw-fly, Nematus similaris, Norton. Rep. U. S. Dep. Agric., 1879, 222-224.

- A Sawfly Borer in Wheat. Bull. Cornell Exper. Station, xi, 127142 (Cephus pygmæus).

Coquillett, $D . W$. Larvæ of Tenthredinidæ tabulated and described. Tenth Report Illinois State Ent., 1881, 63-71.

Corbelli, $\boldsymbol{R}$. Una Nuova specie di Tentredinidi. Verh. z.-b. Ges. Wien, xl, 159 (Macrophya Bertolinii).

Costa, $A$. Storia della Tenthredine produttrice delle galle delle foglie del Salice [Pontania = Nematus gallicola]. Atti dell' Acad. Pontaniana, vi, 281-296, 1852 .

- Miscellanea Entomologica. Atti Acc. Napoli (2), iii, 10, pl. ii, fig. 10 (Cephus politissimus, sp. n.); iv, 19 (Tenthredinidæ from Brazil); v, 13, 15 (Harpiphorus tæniatus and Macrophya trochanterica), vi, 76.

- Miscellanea Entomologica, Memoria terza. Rend. Acc. Napoli (2), iv, 172-3 (New Tenthredinidæ from Greece).

- New Species of Tenthredinidæ from Australia, Brazil, and 1taly. Annuario del Museo Zoologico d. R. Universita di Napoli, ii, 1864.

- Annuario, jii, 26 and 449, 1866 (four new Tenthredinidæ).

- Miscellanea Entomologica. Atti Acc. Napoli (2), iv, 1-19 (Tenthredinidæ of Greece-Laurentia, gen. nov., near Pristiphora).

Cresson, E.T. Catalogue of the Described Species of Tenthredinidæ and Uroceridæ inhabiting North America. Proc. Ent. Soc. Phil., i, 33-39.

- Hymenoptera Texana. Trans. Am. Ent. Soc., iv, 153-292.

- Descriptions of North American Hymenoptera. Trans. Am. Ent. Soc., viii, 152.

- Catalogue of the Tenthredinidæ and Uroceridæ of North America. Trans. Am. Ent. Soc., viii, $53-68$.

- Synopsis of the Hymenoptera of America North of Mexico, together with a Catalogue of the Described Species and Bibliography. Part I, Families and Genera. Tr. Am. Ent. Soc. Sup., vol. 1887; 1-154, 1886. PartII, Catalogue of Species and Bibliography, 1887, 155351.

Crussard. Le Cèphe pygmée ver de la Tige du Blé, son histoire, ses ravages, moyen assuré de la détruire. Neufchateau, 1883.

Curtis, John. Observations on the Natural History and Economy of the Turnip Saw-fly and its Black Caterpillar, called the Black Palmer, Black Canker, Black Ink, Black Slug, and Nigger and Negro. Journ. Agric. Soc. of England, ii, 364-389, t. i, 1841.

- Description of the Nests of Two Hymenopterous Insects inhabiting Brazi], and of the Species by which they were constructed. Trans. Linn. Soc., xix, 249-259, pl. xxxi, 1844 .

- On the Economy of a New Species of Saw-fly. Ann. Nat. Hist., vi, 398, 1850 ; Trans. Linn. Soc., xxi, 39-41, pl. v.

Dahlbom, A. G. Beobachtungen über das Eierlegen, den Embryo und die Larve der Cimber fasciata. Okens Isis., 1837, 76.

- Beopacintungen über der Eierlegen, den Embryo und die Larve des Nematus conjugatus. Okens Isis., 1837, 108. 
Dahlbom, A. G. (continued)-

- Bemerkung. über die Larve des Emphytus succinctus. S. E. Z., $1848,176$.

- Ueber die Verschiedenheiten zwischen Linne's $N$. ribesii u. conjugatus. L. c., 177.

- Ueber die Verschiedenheiten zwischen Linné's und Degeer's Tenthredo salicis. L. c., p. 178.

- Ueber das Eierlegen und den Larvenzustand der Tenthredo crassa, Fall. L. c., p. 178.

- Bestätigung der Vermuthung, dass Blattwespen sich be Hungernoth einaunder angreifen und auffressen. L. c., p. 181.

- Bemerkungen über die von Blattwespen herrührenden galläpfel, L. c., p. 182.

Dahlbom et Sichel. Remarques sur quelques espèces européennes du genre Sivex. Bull. Ent. Fr., 1859, 83, 84.

Dale, J. C. Nematus ribesii, Trichiosoma lucorum (the larva ejects from the pores of the body a white liquid in thin fountain-like columns). Mag. Nat. Hist., vii, 423, 424, 1834.

Dalla Torre, K. W. Tenthredopsis, Costa. Ent. Nachr., viii, 169.

- Hymenopterologische Notizen. Wien. Ent. Z., viii, 124 and 209 (Zygosis, Dicierea, Onychia, Aspicera).

- Zur Nomenclatur der Cynipiden. L. c., xi, 131, 132.

- Die Europäischen Hoplocampa Arten. Ent. Nachr., xv, 165-169.

Dalman, J. $W$. Nägra nya Insect-Genera. R. Vet. Acad., 1, and Stockholm, 122-125. (Xyela pusilla, X. longula), 1819.

Damianitsch, $R$. Hymenopterologische Beiträge. Verh. z.-b. Ges. Wien, xvi, 993-996. (Cephus brachypterus, C. Eberti.)

Dewitz, $H$. Hymenopteren von Portorico. (Schizocerus Zaddachi, sp. nov.) B. E. Z., xxv, 1881, 197.

Dietrich, $K$. Beiträge zur Kenntniss der Kanton Zürich einheimischen Insekten. Hymenoptera. Mtt. Schweiz. Ent. Ges., ii, 347. (Tenthredinidæ.)

Dominique, $J$. Notes pour servir à la connaissance des Tenthrédinides de l'Ouest. Bull. Soc. Sci. Natur. Ouest. Fr., i, 20-30, 235.

Doubleday, E. Larva of Crcesus septentrionalis. Ent. Mag., i, 313, pl. i, fig. 5 .

- Note on the Larva of Sirex gigas. Proc. Zool. Soc., 1849, 95.

Douglas, J. W. Tenthredo testudinea, Klug. E. M. M., xx, 70, 71.

Drewsen, J. C. Note sur le Cimbex femorata. Ann. Soc. Ent. Fr., iv, $169,1835$.

Dufour, $L$. Études pour servir à l'histoire du Nematus ribesii. Ann. Soc. Ent. Fr., 1847 (2), v, 571-581.

- Dissertation sur le Nematus Degeeri. L. c., 583-589.

- Recherches sur l'anatomie des Hyménoptères de la famille des Urocerates. Comp. rendu Ac. Scien., xxxviii, 484-488; Ann. Sc. Natur., i, 201-236, 1854 .

- Description d'une nouvelle espèce de Cephus (C. nigripennis). Ann. Soc. Ent. Fr., 1861, 13, t. i, f. 16; cf, also Bull. Soc. Ent. Fr. $1860,491$.

D'Urban, W. S. M. Galls on the Oak. E. M. M., ii, 141, 142. 
Eckstein, K. Zur Biologie der Gattung Lyda, Fab. Zool. Jahrb. Abth. f. Syst., v, 425-436.

Eversmann, E. S. Fauna Hymenopterologica Volgo-Uralensis, exhibens Hymenopterorum Species, quas in provinciis Volgam fluvium inter et Montes Uralensis sitis observavit et nunc descripsit. Bull. Mos., 1847, 3-64.

Fabre, J. H. Souvenirs entomologiques : études sur l'instinct et les Mœurs des Insectes. Quatrième Série, Paris, 1891; chap. xviii, Sirex gigas.

Fallèn, C. F. Försök till Uppställning och beskrifning på de i Sverige funne arter af Insect Slägtet Tenthredo, Linné. Kong. Vetenskaps Acad. Handlingar, Stockholm, 1807, 179-209; 1808, 37-64, 98-124, 219-227. L. c., 33, 109, 138, 1812.

- Specimen novam Hymenoptera disponendi Methodum exhibens cum tab ænea. Diss. Acad. Lundæ, 1813.

Fennell, J. A. A Singularity in the Larva of Tenthredo amerinæ: Device for entrapping Insects. Mag. Nat. Hist., series 1, xvi, $157,1833$.

Fischer von Waldheim. Observata quædam de Hymenopteris Rossicis. Guérin, Mag. de Zool., v, 1843.

Fitch, E. A. Additional Parasites of Cynips lignicola. Ent., 1872, 243. - New and Rare British Gall-producers observed since the Year 1872. L. c., $x, 27$.

- British Oak-galls. E. M. M., xi, 109. [The record of Dryocosmus cerriphilus, Gir., is a British insect is an error.]

- Aphilothrix globuli, Hart., a Gall-maker New to Britain. Ent., 1874, 24.

- The Breeding of Gall-flies. Ent., 1875, 170-172.

- Gall on Hypochæris radicata. L. c., 233.

- Parasites and Inquilines of Andricus terminalis. Ent., 1876, 29-42.

- New and Rare British Gall-producers observed since the Year 1872. Ent., 1877, 27-29.

- Inhabitants of Kollari Galls. L. c., 44 .

- A Bethylid (Oxyura) bred from Gall of Andricus terminalis. Ent., $1879,24$.

- Hedychrum bred from Cynips Kollari gall. L. c.

- Hymenoptera bred from Cynips Kollari galls. Ent., 1879, 113119.

— Gall on the Great Knapweed. Ent., 1879, 131. [See ante, p. 204.]

- The Galls of Essex : a Contribution to the List of the Insect Fauna of the County. Epping Forest and Essex Nat. Field Club, ii, $98-156$.

Fletcher, James. The Larch Saw-fly, Nematus Erichsoni. Rep. Ent. Soc., Ontario, 1884, 72, 77.

Fletcher, J. $E$. Note on Dimorphism and Alternation of Generation in the Cynipidæ. E. M. M., xiv, 265.

- Notes on Tenthredinidæ. E. M. M., xviii, 127.

- On Parthenogenesis in Tenthredinidæ. E. M. M., xviii, 127, 180.

- List of Cynipidæ taken in Worcestershire. Ent., xiii, 10.

- Additions to the Casual Inhabitants of Galls. Ent., xiv, 21. 
Fletcher, J. E. (continued)-

- Notes on Tenthredinidæ. E. M. M., xix, 206, 207.

- On Parthenogenesis in Tenthredinidæ and Alternation of Generations in Cynipidæ. E. M. M., xvi, 269, 270.

Fockeu, $H$. Les Hymenoptérocécedies du Saule. Rev. Biol., iii, 35-40.

Förster, A. Einige neue Arten aus der Familie der Blattwespen. S. E. Z., $1844,262-287$.

- Neue Blattwespen. Verh. des Naturh., Ver. d. preuss. Rhein., xi, 265-350, 421-436, 1854.

- Eine Centurie neuer Hymenoptera. Verh. d. Nat., Ver. d. Rhein. und Westph., vii, 287. Tenthredo pictipes, i, 1850.

- Die 2te Centurie neuer Hymenoptera. Verh. ver. pr. Rhein., 256 -258 (Eucoela decipiens, E. sculpturata, E. rufula, Dolerus ochroneurus), 1. c., 143. N. Gen. Phanacis [Ph. centaureæ], 1. c., 145.

- Ueber Gallwespen. Vehr. z.-b. Ges. Wien, 1869, 327-370.

Fonscolombe, Boyer J. C. Description des Insectes de la famille des Diplolèpaires que se trouvent aux environs d'Aix. Ann. Sc. Nat., 1832, t. xxvi, 184, 198.

Foulques de Villaret. Mémoire sur quatre nouvelles espèces de Tenthrédines. Ann. Soc. Ent. Fr., i, 303, pl. ii, 1832.

Fox, W.J. Report on the Hymenoptera collected in West Greenland (Nematus borealis). $\quad$ Ent. News, 1892.

Frauenfeldt, G. Von. Die Gallen. Versuch die durch Insecten an der Pflanzen verursachten Auswüchse nach ihren Haupttypen und Wachsthumsverhältnissen naturgemäss zu gruppiren. Sitzb. d. Mathem. Naturw. Wien, xv, 121, 255-266.

- Zoologische Miscellen. Vergrosserung der Eier bei Nematus fuscus, Lep., und Tenthredo, sp. Verh. z.-b. Ges. Wien, 1864, 693-695.

- Weitever Mittheilung über die Rapswespe. L. c., 1866, 839-843.

- Zoologische Miscellen. Xiphidria camelus. L. c., 1868, 885, 886.

- Dritter Beiträge zur Fauna Dalmatiens. Verh. z.-b. Ges. Wien, xi, 102. (Hylotoma, sp. n., 105 ; Cephus, sp. n.)

Frey-Gessner, Fr. Kohl, and Kreichbaumer. Die Typen zu Jurine's Werk, Nouvelle methode de classer les Hyménoptères et les Diptères. M. T. Schw., Ent. Gess., vi, 387-396.

Freymouth. Beschreibung neuer arten Blattwespen die von Fedts zenko im halo Taravschane gesammelt sind, nebst einer synoptischen Tabelle für die asiatischen und europäischen Tarpa. Soc. Imp. des Amateurs des Sc. Nat. Moscow, 1870, 213.

Froggatt, $W . W$. Notes on the Life History of certain Saw-flies (Perga), with Description of a New Species. Proc. Linn. Soc. New South Wales (2), v, 283-288.

- Descriptions of a New Genus and Two New Species of Tenthredinidæ. L. c., $487-490$.

Gillette, C. P. Notes on certain Cynipidæ, with Descriptions of New Species. Psyche, v, 183-188, 214-221.

- New Cynipidæ. Ent. Am., vi, 21-25, 1890.

- Descriptions of New Cynipidæ in the Illinois State Laboratory of Natural History. Bull. 1llinois Lab. Nat. Hist., iii, 191-206. 
Gimmerthal, B. A. Einige in Livland aufgefundene und benannte Sägewespen. Bull. Mosc., vii, 122-128, 1834 .

- Beschreibung einiger neuen in Livland aufgefundenen Insecten, ii. Bull. Mosc., ix, 431-447, 1836.

- Beschreibung einiger neuen Blattwespen. S. E. Z. 1844, 36.

- Einiges über die Blattwespen im Allgemeinen nebst einer Uebersicht der Gattungscharactere und die bis hierzu in Livland und Kurland beobachteten Arten mit einigen Bemerkungen daran Arbeiten des Naurforsch. Vereins in Riga, i, 23-60, 1847.

- Beobachtete Metamorphose einer neuen Fliegenspecies und einer bereits bekannten Blattwespen (Nematus appendiculatus). Arbeit. d. Naturforsch. Vereins in Riga, 1848, 330 .

Giraud, $J$. $E$. Note sur quelques Hyménoptères (Xiphydria dromedarius et ses Parasites). Verh. z.-b. Ges. Wien, iv, $603-608,1854$.

- Observations sur quelques espèces d'Hyménoptères rares ou peu connues trouvés dans les environs de Vienne. L. c., vi, 187, 188, 1856. (Onychia et Callispidia, Nematus abdominalis, Pz.)

- Description de quelques Hyménoptères nouveaux ou rares. L. c., vii, 181-184, 1857 (Tenthredinidæ, n. sp.).

- Description de deux Hyménoptères nouveaux du genre $L y d a$, accompagnée de quelques observations sur les espèces connues de ce genre que se trouvent en -Autriche. L. c., xi, 81-92.

- Signalements de quelques espèces nouvelles des Cynipides et de leurs Galles. L. c., 1859, 337 .

- Enumération des Figitides de l'Autriche. L. c., 1860, 123.

- Description et Metamorphoses d'une nouvelle Tenthrédine du genre Selandria (S. xylostei). L. c., xiii, 1297.

- Miscellanies hyménoptérologiques : II. Obselvations sur les fausses chenilles épineuses que vivent sur le cbêne, et biologie de la Dineura verna, Kl. Ann. Soc. Ent. Fr., i (5), 375.

- Note sur le Janus femoratus, Curtis, Hyménoptère de la famille des Tenthrédines. Am. Soc. Hym. Fr., 1870, 27-30.

- Communication sur diverses galles du chêne, et sur les Insectes qui les forment. Ann. Soc. Ent. Fr., 1886, 197-200.

Gliemann. Geographische Beschreibung von Island Altona (Ten. thredo, $2 \mathrm{sp}$.), 1824.

Gorski. Notice sur le fausses chenilles qui détruisent le parenchyme des feuilles des cerisiers. Analecta ad Entomographicum imp. ross., $186-203,1852$.

Goureau. Notes sur les ravages produits sur les vinetiers du Berbéris par la larve de l'Hylotoma enodis. Bull. Soc. Ent. Fr. (4), 11, 15.

- Note sur le Hylotoma enodis et Nematus ribis. L. c., 1857, 28.

- Sur les mœurs du Cephus compressus. I. c., 131, vi, 17, 1858.

Gradl, $\boldsymbol{H}$. Aus der Fauna des Egerlandes. Ent. Nachr., vii, 294-300 (Cephosoma, gen. nov.; Dolerus rufipes, Phyllotoma nigrescens, Nematus superbus).

- Verzeichniss europäischer Hautflügler. L. c., 1882, 129-155.

G'uérin-Méneville. Urocerus Lefebvre. Mag. de Zoologie, 1833, No. 68.

- Notices sur quelques Insectes nuisbles au Froment, au Seigle, à l'orge et au Tréfle. Mém. de la Soc. Roy. et. Centr. d'Agriculture, Paris, 1843. 
Hagen, $H$. On the Natural History of Gall Insects. Can. Ent., x, 85-94 (1878).

Handlirsch, $A$. Die Metamorphose zweier Arten der Gattung Anacharis, Dalm. Verh. z.-b. Ges. Wien, xxxvi, 235-237, pl. vii, f. 1-4.

Harrington, $W . H$. Note on Oryssus Sayi and North American Species. Can. Ent., xiv, 81-86.

- New Species of Canadian Tenthredinidæ. Canad. Ent., xxi, 95-99.

Hartig, G. L. and Th. Forstlichen und forst. naturwissenschaftliches Conversations-Lexicon, Berlin, 1834.

Hartig, Th. Hymenopterologische Mittheilungen. Stett. Ent. Zeit., 1840, 19-28. Gen. Trichiosoma, ii, Uebersicht der Nematiden. Republished Ent. Nach., 1884, 317-326, by Kriechbaumer.

- Ueber die Familien der" Gallwespen. Germ. Zeit., ii, 1840, 176; Erster Nachtrag, iii, 1841, 322; Zweiter Nachtrag, iv, 1843, 395.

Healy, Charles. Life Histories of Saw-flies : Phyllotoma melanopyga, Ent. iv, 176-178 (= microcephala); Phyllotoma tormentillæ, Ent., No. 58, 140, 141 ; Phyllotoma microcephala, Ent., 60, 177 (= vagans, Fall.); Fenusa fuliginosa?, Ent., No. 63, 1869, 225; Druida parviceps, Ent., No. 62, 1869, 208; Fenusa pumila, Ent. 62, 211, 212; Fenusa ulmi, Ent., No. 68, 297; Fenusa pygmæa, Ent., No. 68, 300.

- Observations on the Economy of the Saw-fly (Phyllotoma aceris, McLach.) that mines the Leaves of Maple. E. M. M., iv, 105.

Heeger, E.-Naturgeschichte der Akorn-Blattwespe Tenthredo (Dolerus) nigra. Sitzun. der Math.-Natur., Kl. de König Acad. zu Wien, viii, 214-217, Taf. vii, 1851.

Heer, Oswald. Die Insecten fauna der Tertiärgebilde von Oeningen und Radoboj in Croatien, part ii (Cephites).

Herrich-Schäffer, - Fortgesetzt von Panzer Deutschlands Insecten, Hefte 120-129, 1834.

Heyden, $L$. von. Beiträge zur Kentnniss der Hymenopteren Fauna der weiteren Umgegend von Frankfurt a/M. Ber. Senck. Ges., 1887, 65.

Hope, J. F. Note on Sirex juvencus. Proc. Ent. Soc., 1836, 96.

Huart, $V . A$. Une nouvelle espèce de Lyda. Nat. Can., xi, 144-149.

Inchbald, Peter. Cryptocampus angustus (willow-gall saw-fly). E. M. M., i, 47 .

- Note on Croesus septentrionalis. E. M. M., v, 21.

- Note on the Currant Gall on Salix herbacea. E. M. M., v, 21.

- Aulax sabaudi, one of the Cynipidæ bred from a Gall on Hieracium boreale. E. M. M., ii, 46,47 .

Jack, J. G. Notes on Three Species of Hylotoma. Psyche, vi, 10, 11.

$J a k o w l e w, A$. Quelques matériaux pour servir à la connaissance de la distribution géographique des Mouches à Scie (Tenthredinidæ) en Russie. Hor. Ent. Ross., xx. 236-241.

- Insecta in itinere cl. N. Przewalskii in Asia centrali, novissime lecta Tenthredinidæ. Hor. Ent. Ross., xxi, 160-164.

- Quelques nouvelles espèces des Mouches à Scie de l'Empire Russe. Hora. Ent. Ross., xxii, 368-375.

- Diagnoses Tenthredinidarum novarum ex Rossia europæa, Sibiria, Asia, India, et confinum. Hor. Ent. Ross., xxvi, 1-62. 
Karsch, F. Neue Zoocecidien und Cecidozoen. Zeits. f. d. ges. Naturw., 1880, 286.

Kawall, $H$. Entomologische Notizen aus Kurland. S. E. Z., 1858, $65-72$.

- Beiträge zur Kenntniss der Hymenopteren Fauna Russlands, Bull. Mosc., xxxvii, 293-303.

Kerville, H. G. de. Sur le Larve de Monophadnus iridis. Bull. Soc. Ent. Fr., 1884, 150-152.

Kidd, H. W. Notes on the Woolly Gall of the Oak. E. M. M., ii, 141.

Kieffer, J. J. Aulax hypochæridis, sp. nov. Verh. z -b. Ges. Wien, xxxvii, 205, 206.

- Les Hymenoptera-Cécidies de Lorraine. Feuill. Nat., xxi, 230-234, $227-254$; t. c. xxii, $43-46$.

Kirby, W. F. Description of a New Species of Saw-fly from Albania. Ann. N. H. (5), xviii, 497.

- Descriptions of several New Genera and Species of Chalcididæ and Tenthredinidæ. Journ. Linn. Soc., xx, 28-37.

- Descriptions of New Species of Tenthredinidæ, Cynipidæ, and Chalcididæ in the British Museum. Ann. N. H. (6), iv, 141-144.

- Description of a New Species of Saw-fly from Greece. E. M. M., $\mathrm{xx}, 215$.

Kirchner, L. Verzeichniss in der Gegend von Kaplitz, Budweiser Kreises in Böhmen vorkommenden Aderflügler. Verh. z.-b. Ges. Wien, 1854, 285-290.

Klug, F.* Die Blattwespen nach ihren Gattungen und Arten zusammengestellt. Magazin der Gesellschaft naturforschender Freunde zu Berlin, ii, 261-283. Tarpa und $L y d a, 1808$.

- L. c., vi, 45-62, Lophyrus 276-310; Pterygophorus und Hylotoma, 1814.

- L. c., vii, 120-131, Tenthredo.

- L. c., viii, 42-84, 110-116, 179-219, 273-307 (Tenthredo), 1818.

- Die Blattwespen der Fabricischen Sammlung. Wiedemanns Zoologische Mag., ii (3), 64-91, Altona, 1819.

- Uebersicht der Tenthredinidæ der Sammlung der Berliner Entomologischen Museum. Jahrbucher der Insectenkunde Berlin, 223253 , and of ii, figs. $5,10,1834$.

- Versuch einer Darstellung der Familien und Arten der Blattwespen Gattung Cimbex Fab. L. c., i, 1829.

Kollar, V. Ueber springende Cynips-Gallen auf Quercus cerris. Verh. z.-b. Ges. Wien, $1857,513$.

- Die Cerr. Eichen Blattwespe Tenthredo (Emphytus) cerris. Denkschr. der Wien. Akad. d. Wiss., 1850, 48.

Konow, F. W. Bemerkungen ueber Blattwespen. D. E. Z., xxviii, $305-354$.

- Bemerkungen über Blattwespen. D. E. Z., xxx, 73, 82.

- Ueber die Blattwespen Gattungen Strongylogaster, Dahlb., und Selandria, Klug. W. E. Z., iv, 19-26.

* The whole of Klug's papers on Saw-flies have been republished in one volume (4to.) by Kriechbaumer, Berlin, 1886. 
Konow, $F \cdot W$. (continued)-

- Ueber Blattwespen. W. E. Z., iv, 295-301.

- Sieben neue Allantus Arten. W. E. Z., v, 17-21.

- Ueber mehrere neue und einige schon bekannte Blattwespen. L. c., $37-41$.

- Ueber einige Blattwespen. I. c., 107.

- Die Europäischen Blennocampen. L. c., 183, 211, 243, 267.

- Description d'une espèce nouvelle de Tenthrède. Rev. d. Ent., v, 137.

- Zwei neue Arten der Blattwespen Gattung Thomsonia. W. E. Z., 1884, 307, 308.

- Ueber einige Blattwespen. W. E. Z., 1886, 108-110 (Tenthredopsis, Costa, Eriocampa cethiops, F. Auengmenus).

- Bemerkungen ueber Blattwespen. D. E. Z., xxx, 1886, 73-82.

- Description de quelques espèces nouvelles de Tenthrédines, et tableau analytique du genre Abia. Rev. d'Ent., vi, 1-5.

- Neue griechische und einige andere Blattwespen. W. E. Z., vi, $19-28$.

- Nachtrag zu den Blennocampiden. W. E. Z., vi, 273-283.

- Eine neue Macrophya. Art. Suc. Ent., ii, 112, 113.

- Zwei neue Blattwespen-Arten. S. B. Akad. Berlin, 1888, 187-193.

- Die Blattwespen Gattung Allantus, Jur. D. E. Z., xxxii, 209-220.

- Tenthredinidæ Europæ. Deut. E. Zeit., 1890, 225-255.

- Tableaux analytique et systématique du genre Tenthredopsis, Costa. Rev. d'Ent., ix, 63-80.

- Neue palæarctische Blattwespen. W. E. Z., ix, 8-13.

- Bemerkungen und Nachträge zum Catalogus Tenthredinidarum Europæ. 'D. E. Z., 1891, 209-220.

- Neue Blattwespen. Eine neue Athalia aus Arabia. Neue Kauka. sische Tenthrediniden. W. E. Z., x, 41-49.

- Analytische Uebersicht der europäischen Arten der Tenthrediniden Gattung Schizocera, Latr. W. E. Z., 1892, 11-22.

Kessler. Die Lebensgeschichte von Ceutorhynchus sulcicollis, Gyll., und Nematus ventricosus, Kl. Cassel, 1866.

Kriechbaumer, $J$. Hymenopterologische Beiträge. Neue Blattwespen der Gattung Allantus. Verh. z.-b. Ges. Wien, xix, 586-597.

- Blattwespenstudien. C. B. Ver. Regenst., xxxiv, 9-20, 135-143, $145-151$.

- Ueber Cimbex venusta. Stett. E. Z., 1874, 417, 418.

- Hymenopterologische Mittheilungen von Hartig. Revidirt mit einem Vorworte versehen. Ent. Nachr., 1884, 317-326.

- Blattwespen Studien. Ent. Nachr., vii, 98-101 (Hylotoma Graeffei, H. pallipes, Allantus monozonus).

- Zwei neue Macrophya Arten. Ent. Nachr., xvii, 188.

Lacaze-Duthiers, $H$. Recherches sur l'armure génitale femelle des Insectes. Ann. Scien. Natur. (3), xii, 353-374; xiv, 17-52, 1849.50.

- Recherches pour servir à l'histoire des Galles. Ann. Sc. Nat. Bot., (3) xix, 332 .

Landsell, $H$. An Apterous Saw-fly. Ent., xviii, 247.

Latreille, $P$. A. Mémoire sur un nouveau genre d'Insecte (Oryssa) présenté à l'Inst. le 28 flor., an. iv, 1795. 
Latreille, P. A. (continued) -

- Hist. nat. Insectes. Ency. Méthodique, viii, 557-561; Oryssa, 678-696; Pamphillus, 1811.

Lesne, $P$. Sur le genre Cimbex. Ann. Soc. Ent. Fr., 1889, cxlviii.

Lethierry, $L$, and Carpentier, $L$. Matériaux pour le Catalogue des Hyménoptères du Nord, du Pas de Calais, de la Somme, et de l'Oise (Tenthrédiniłes). Mém. Soc. L. N. Fr., vii, 240-253.

- Matériaux pour le Catalogue des Hyménoptères du Nord, du Pas de Calais, de la Somme, et de l'Oise. Mém. Soc. Linn. d. Nord Fr., vi, 247-267 (Tenthredinides).

- Le Perineura Konowi, Leth. Bull. Soc. L. Nord Fr., viii, 218.

Lewis, $R$. H. Case of Maternal Attendance on the Larva by an Insect of the Tribe of Terebrantia, belonging to the Genus Perga, observed at Hobarton, Tasmania. Trans. Ent. Soc., i, 232-234.

Lichtenstein, Jules. Alternation of Generation in the Cynipidæ. E. M. M., xviii, 225.

- Les Cynipides monoiques. Petit Nouvelle Entom., 1878, 225.

- Zur Generationswechsel der Cynipiden. Ent. Nachr., iv, 159.

Liebel, $R$. Die Zoocecidien (Pflanzen-deformationen) und ihre Erzeuger in Lothringen. Zeit. f. Naturw., lix, 531-579.

- Die Zoocecidien (Pflanzen-deformationen) der Holzewächse Lothringen. Ent. Nachr., xviii, 257-287.

Iintner, J.A. Fourth Report on the Injurious and other Insects of the State of New York-Amphibolips prunus, pp. 42-44; Aulacomerus lutescens, 44-46 ( = Cladius viminalis).

Löw, Fr. Zoologische Notizen, i. Verh. z.-b. Ges. Wien, xvi, 953.4 (Cephus compressus on Pyrus. Life-history of Lyda inanita).

- Zool. Notizen, ii. Lyda inanita, l. c., xvii, 747.

- Bemerkungen ueber Cynipiden. Verh. z.-b. Ges. Wien, 1884, 321326 (1, Chilaspis nitida and C. Lowii ; 2, Neuroterus aprilinus, Giraud; Neuroterus Schlechtendali, Mayr; 3, Xestophanes brevitarsis, Thom. = tormentillæ, Schlecht.; 4, Aulax hieracii, Bouché ; 5, Cynipidengallen an Hypochæris radicata, Linn.).

Lucas, $H$. L'histoire naturelle des Animaux articulés de l'Algérie : iii, Hyménoptères (Exploration scientifique de l'Algérie), 1849.

- Un mot sur le Diastrophus rubi. Ann. Soc. Ent., Fr., 1862, 369372 .

- Note sur le Lophyrus pini, L., et sur son parasite le Torymus obsoletus, F. Ann. Soc. Ent. Fr. (4), iv.

- Notice sur Cimbex amerinæ trouvée sur les murailles de Sebastopol. Bull. Soc. Ent. Fr., 1857, 30.

- Parasites of Cimbex amerinæ (Mesochorus testaceus, Gr., and Cam. poplex, sp.). Bull. Soc. Ent. Fr., 1858, 17.

- Note sur le Cimbex amerinæ comme habitent le nord de l'Afrique. Bull. Soc. Ent. Fr., 1860, 22.

McLachlan, $R$. Additions, \&c., to the British Tenthredinidæ, E. M. M., iv, 102.

- Additional Notice respecting the Maple-mining Saw-fly (Phyllotoma aceris), E. M. M., iv, 123. 
McLachlan, $R$. (continued)-

- Three Species of Tenthredinidæ New to Britain. E. M. M., x, 113.

- Phyllotoma melitta, Newman = Fenusa betulæ, Zaddach. E. M. M., vi, 213.

- Tenthredo olivacea of Klug, a New British Saw-fly. E. M. M., v, 44.

Maeklin. Beiträg zur Kenntniss der geographischen Verbreitung der Insecten im Norden, mit besonderer Berucksichtigung der Fauna Scandinaviens und Finland. S. E. Z., 1857, 86.

Magretti, $P$. Varietà e specie nuove di Imenotteri Terebranti, Tenthredinidei. Bull. Soc. Ent. Ital., xviii, 1886.

- Imenotteri di Siria, raccolti dall' avoti Augusto Medema, con descrizione di alcune specie nuove. Ann. Mus. Genov. (2), ix.

- Varietà e specie nuove d' Imenotteri, Terebranti, Tentredinidei. Bull. Soc. Ent. Ital., xviii, 24-29.

- Di una galla di Cinipide trovata sulle radici della vite (Vitis vinifera). L. c., xvii, 207, 208.

- Varietà ed anomalie osservato in alcune specie di Tenthredini. L. c., xiv, 239-241.

- Recerche microscopiche sopra i liquidi discrezione e di arcologione nelle larve d'alcuni Imenotteri, Tentredinidei. Bull. Scient., iv, 58,59 .

Malley, $F$. W. Another Strawberry Saw-fly (Monostegia ignota). Ins. Life, ii, 137-140, figs.

Manning. Notes upon the Black Caterpillar, or Larva of Athalia centifoliz. Proc. Ent. Soc., ii, 1839, 64.

Marshall, D. Account of the Black Canker Caterpillar which destroys the Turnips in Norfolk. Phil. Trans., lxxiii, 217, 222, 1783.

Marshall, T. A. On some British Cynipidæ. E. M. M., iv, 6, 101, 124, 146, 171, 223, 271.

- Hymenoptera (Cynipidæ). Ent. Ann., 114-121.

- On some British Cynipidæ. E. M. M., xi, 178.

Martlett, C. The Final Moulting of Tenthredinid Larvæ. Proc. Ent. Soc. Wash., ii, 115-117.

- Notes on a Red Cedar Saw-fly. Trans. Kansas Acad., x, 80-82.

Mayr, G. L. Beschreibung einer neuen Gallwespen. Verh. z.-b. Ges. Wien, xxx, 5 (Andricus Adleri).

- Eine neue Cynipide aus Mexico. Verh. z.-b. Wien, xxxvi, 369.

Mayr's work on the Central European Oak-galls has been translated, with notes, by F. Walker and E. A. Fitch in the Entomologist, as follows :-Aphilothrix radicis, Ent., vii, 2; Biorhiza aptera, 3 ; Aphilothrix corticis, 50; A. rhizomatis, 51; A. Sieboldii, 52; Cynips cerricola, 73; Dryocosmus cerriphilus, 75 ; Dryophanta macroptera, 98; Andricus noduli, 99; Cynips Hartigi, 145; C. funicicola, 146; C. conifica, 170 ; Aphilothrix serotina, 170; Trigonaspis megaptera, 193 ; Cynips argentea, 194; C. hungarica, 217; C. tinctoria, 218; C. Kollari, 241 ; C. lignicola, 265 ; C. conglomerata, 266 ; C. glutinosa, Gir., viii, 73 ; C. coriaria, 75 ; C. polycera, 97 ; C. caliciformis, 99 ; C. amblycera, 121 ; C. galeata, 121 ; Aphilothrix lucida, 145; A. gemmæ, 146; A. solitaria, $169 ; A$. globuli, $254 ;$ A. autumnalis, 255 ; A. collaris, 289 ; A. callidoma, 290; A. glandulæ, ił, 1 ; A. cle- 
Mayr (continued)-

mentinæ, 2; Synophus politus, 26; Andricus terminalis, 28; A. inflator, 50 ; A. curvator, 51 ; A. circularis, 51 ; A. Burgundus, 74; Spathegaster Giraudi, 75; S. aprilinus, ix, 76; ? Cynips aries, 77; C. gemmea, 78; Biorhiza renum, 115; B. synaspis, 117; Dryophanta scutellaris, $121 ; D$. foli, $123 ; D$. longiventris, $146 ; D$. divisa, 147 ; D. agama, 149, 150; D. disticha, 171; D. cornifex, 172; Andricus u'næformis, 192; A. curvator, 195; A. testaceipes, 219; petioli, 219; A. multiplicatus, 220; A. cydoniz, 245; A. nitidus, 246 ; A. crispator, 268; Neuroterus numismatis, х, 67 ; $N$. lenticularis, 86 ; N. fumipennis, 121 ; N. lreviusculus, 122; N. lanuginosus, $160 ; N$. ostreus, $161 ; N$. saliens, $172 ; N$. minutulus, 173 ; Spathegaster baccarum, 206; S. tricolor, 234; S. albipes, 235 ; S. verru. cosa, 249 ; S. vesicatrix, 250 ; S. nervosa, 297; S. marginalis, 298 ; A. æstivalis, xi, 31 ; A. grossularix, 33 ; A. ramuli, 87; A. amenti, 114 ; A. occultus, 115 ; A. 4-lineatus, 133; A. verrucosus, 136; A. Schlechtendali, 145; Cynips seminationis, 146 ; C. caput-medusæ, 180 ; C. calicis, 182; Spathegaster glandiformis, 204; Andricus glandium, 205; Cynips ramicola, 207; Aphilothrix albopunctata, 220 ; Andricus singularis, 221 ; Spathegaster Taschenbergi, 222.

Meyer-Dür. Weitere Beiträge zur Schweizerischen Hymenopterenkunde. Mittheil. d. Schweizer. Ent. Ges., i, 37.

Middendorff, A. Th. von. Reise in den aussersten Norden und Osten Sibirens : ii, Zoologie (edited by Erichsen, 1851).

Miller, C. Note on a Larva mining the Leaves of Acer campestre. Ent. Weekly Intelligencer, i, 110.

Mocsáry, A. Studia Synonymica. Term. Füzetek, xi, 12 (Tenthredinidæ).

- Zur Hymenopteren Fauna Siebenbürgens. Verh. u. Mitth. d. Siebenburg, 1874, 117-122.

- Species aliquot Tenthredinarum novæ. Ent. Nachr., xii, 2, 3.

- Hymenoptera nova Europæa et exotic. Termes Füzetek, xiii, 1883.

- Tcnthredinidæ et Siricidæ novæ. Term. Füzetek, xiv, 155-159.

- A magyarorszagi fa. ronto darágsok. Rov. Lapok., iii, 9 (Hungarian Siricidæ, spp. nov.).

Moore, J. Remarks on the Study of Entomology, and on a Hymenopterous Insect which devour's the Leaves of the Gooseberry Bush. Mem. of the Lit. and Phil. Soc. Man , iv, 112, 134, 1831.

Motschulsky, V. Cimbex villosa and Hylotoma nigronodosa, spp. nov: Bull. Mosc., ii, 499.

- Catalogue des Insectes reẹus du Japon. Bull. Mosc., xxxix, 182, 183 (Dolerus coxalis, Tenthredo picta, and T. adusta).

Müller, $A$. In Memoriam Wilson Armistead, of Virginia House, Leeds. Zool., n. s., 1868, 1196-1208.

- An Economic Use for the Galls of Cynips lignicola. E. M. M., $\checkmark, 171$.

- Nematus Vallisnieri, Hartig, ovipositing under Difficulties. I. c., viii, 109.

- On the Economy of Nematus saliceti, Fallén. L. c., vi, 29.

- Notes on Nematus pedunculi, Hartig. L. c., vi, 184.

- On the Occurrence of Andricus curvator, Hartig, in Britain. L. c., vi, 39. 
Müller, $A$. (continued)-

- Note on the Dimorphism of American Cynipidæ, \&c. L. c., vii, 38.

- Cynips longiventris, Hartig, a Species New to the British List. L. c., $1870,108$.

- Andricus inflator, Hartig, occurring in Britain. L. c., vii, 157.

- Occurrence in Britain of Neuroterus ostreus, Htg. L. c., vii, 209.

- British Gall-insects. Ent. Ann., 1872, 1.

Newman, Ed. Larva of Lyda sylvatica, Allantus scrophulariæ, Nematus dimidiatus. Ent. Mag., i, 313, 314.

- Entomological Notes. Ent. Mag., i, 415.

- Entomological Notes, Figites syrphi. Ent. Mag., ii, 515.

- "Rusticus." Destructiveness of Athalia centifolia. Ent. Mag., iii, $339,1836$.

- Notes on Tenthredinidæ. Ent. Mag., iv, 258-263.

- Entomological Notes. Int. Mag., v, 484 (Druida asticta), 1838.

- Entomological Notes. Ent., i, 89, 90, 1841.

- "Rusticus" on Nematus grossularix. Ent., i, 148.

- Camponiscus Healæi. Ent., iv, 215 and 319.

- Collected Observations on British Saw-flies. Ent., xi, 37, 88, 147.

- Life History of the Pear-tree Slug. Ent., 1875, 258-268.

Nerén, C. H. Bidrag till Kännedomen om lefnadsättet hos nägra Skandinaviska Arter af Sägstekelslägtet Emphytus. Ent. Tidskr., xii, $5-14$.

Norton, Ed. On the Hymenoptera of the Genus Allantus in the United States. Bost. Journ. Nat. Hist., vii, 236.

- Catalogue of Several Genera of Tenthredinidæ in the United States. Proc. Bost. Soc. Nat. Hist., viii, 150-161.

- Notice of the Genus Selandria: Descriptions of Several of Harris's Named Tenthredinidæ. Proc. Bost. Soc. Nat. Hist., viii, 219-224.

- Catalogue of American Species of Tenthredo as arranged by Hartig. L. c., ix, 116-122.

- On the Synonyms of Cimbex americana. Proc. Ent. Soc. Phil., i, $198-200$.

- Notice of Several New Species of Tenthredinidæ. Proc. Ent. Soc. Phil., i, 143.

- Notes on Tenthredinidæ, with Descriptions of New Species. L. c., iii, $5-16$.

- Catalogue of the Described Tenthredinidæ and Uroceridæ of North America. Trans. Am. Ent. Soc., i, 31, 193; ii, 211, 321.

- Notes on North American Tenthredinidæ, with Descriptions of New Species. Trans. Am. Ent. Soc., iv, 77, 86.

Olivier, A. G. Hist. Naturelle Insectes. Ency. méthodique, viii. Nemate, $163-168,1811$.

Ormerod, E. A. Considerations on Abnormal Gall Growth. Ent., xi, 82.

- Modifications of Gall Growth. L. c., 129.

- Acorn and Bud Galls of Quercus cerris. L. c., 201.

- Turkey Oak Galls, x, 42, 43.

- Oak Gall, Aphilothrix corticis, x, 165.

Osborne, J.A. On some Points in the Economy of Zaræa fasciata. E. M. M., xix, 97-100.

VOL. IV. 
Osborne, J. A. (continued)-.

- Some Further Observations on the Parthenogenesis of Zaræa fasciata. E. M. M., xx, 145-148.

- On the Male of Zaræa fasciata. E. M. M., xx, 205-207.

Osten-Sacken, $\boldsymbol{R}$. On the Cynipidæ of the United States and their Galls. Proc. Ent. Soc. Phil., i, 47-72.

- Additions and Corrections. L. c., i, 241-259.

- Contributions to the Natural History of the Cynipida of the United States and their Galls. L. c., ii, 33-49, 331, 380; Trans. Am. Ent. Soc., iii, $54-64$.

Patton, W. H. On certain Hymenoptera (Allantus, Xiphidria) Can. Ent., xi, 12-15.

Parfitt, E. Note on Cynips lignicola and its Parasite. Zool., 1856, $50-70$.

Paszlavsky, Josef. Cynips superfetationis, Gir. Ein beitrag zur Kennt. niss der Cynipiden. Math. und Natur. Berichte aus Ungarn, ii, $172-177$.

- Beiträge zur Biologie der Cynipiden. W. E. Z., 1883, 129-132, $171-174$.

- A rozsagubacs fej lödéséröl (On the Structure and Origin of the Bedeguar). Termes Füzetek, v, 198.

Peck, W. D. Natural History of the Slug Worm. Collection of the Massach. Historical Society, 280, 1799.

Perez, T. Imenotteri nuovi o poco conoscinti della Sicilia. Nat. Sicil., iv, 185.

Philippi, $\boldsymbol{R}$. A. Beschreibung einiger neuen chilenischen Insecten : i, Brachyxiphos, nov, gen. Stett. Zeit., 1871, 253.

Provancher, L. A New Tenthredinid (Synairema americana). Can. Ent., xvii, 50.

- Les UUrocérides de Québec. Nat. Can., vii, 368-376.

- Faune Canadiennne. L. c., $\mathrm{x}$-xiii.

- Additions à la Faune hyménoptèrologique de la province de Québec.

- Additions et corrections à la Faune hyménoptèrologique de la province de Québec. Quebec, 1886.

$P u l s, J$. Note sur les Hyménoptères rapportés des Provinces occidentales de la Transcaucasie par M. Deyrolle: Tenthrédinides. Ann. Soc. Ent. de Belgique, xiii, 147-152.

Puton, Aug. Notes sur quelques Hyménoptères, et description d'une espèce nouvelle. Ann. Soc. Ent. Fr., 1870, 97 (Emphytus patellatus).

Raddon. Note on Sirex juvencus. Proc. Ent. Soc., 1836, 95.

Radoszkowski, O. Hyménoptères de Korée. Hor. Ent. Ross., xxiv, 232 (Hylotoma anceps, $H$. assimilis, spp. n.).

Ratzeburg, I. T. C. Cimbex Humboldtii, eine nene Blattwespen der Deutschen Fauna. S. E. Z., 1844, 148.

Raymond, G. Observations sur l'organisation et les mour's du Nematus ribesii. Mem. Soc. Seine et Oise, xiii, 237-272.

- Observations sur l'organisation et les mœurs du Nematus ribesii, Scop. Ann. Soc. Ent. Fr. (6), i, 286-312; 
Reinhard, D. Die Figitiden der Mittleren Europas. B. E. Z., 1860, 204.

- Entomologische Bemerkungen. S. E. Z., 1856, 110.

- Die Hypotesen ueber die Fortpflanzungsweise bei den eingeschlechtingen Gallwespen. D. E. Z., 1865, 1.

- Zur Entwickelungs-Geschichte des Tracheen-Systems der Hymenopteren. L. c., 187 (Aulax).

Riley, C. V. A New Genus of Proctotrupidæ (Didictyum). Am. Ent., iii, $52,1880=$ Hexaplasta : cf. 4th U. S. Ent. Com., 115.

- A New Oak-gall on Acorn Cups-Cynips qr. glandulosus. Trans. St. Louis Acad. Sc., iii, 577, 1878.

- Honey-producing Oak-gall (C. q. mellaria). Am. Ent., iii, 298.

- The American Cimbex (C. americana). Rep. Ent. U. S. Dept. Agric., 1884, 334-336, pl. v, fig. 1.

- The Sweet Potato Saw-fly (Schizocerus ebenus, Norton). Ins. Life, i, $43-45$.

- The Willow-shoot Saw-fly (Phylloccus integer, Norton). Ins. Life, i, 8-11.

- On the Habits of Thalessa and Tremex. Ins. Life, i, 168-180, and 253.

— Saw-fly on Polygonum dumetorum. Ins. Life, i, 345-6.

- The Dogwood Saw-fly (Harpiphorus varians, Norton. Ins. Life, i, $232-243$.

- The Wheat Saw-fly (Cephus pygmæus). Ins. Life, ii, 286.

- The newly imported Rose Saw-fly (Emphytus cinctus). Ins. Life, ii, 378.

- Rose Saw-flies in the United States. Ins. Life, $\mathbf{0}, 6-12$. (Cladius pectinicornis, Emphytus cinctus, Eriocampa rosæ.)

Riley and Marlatt. Wheat and Grass Saw-flies. Ins. Life, iii, 168179.

Roebuck, W. D. Yorkshire Hymenoptera. Report on Present State of Knowledge and First List of Species. Trans. York. Nat. Union, 1877, 25-34.

Rogenhofer. Zur Lebengeschichte von Cephus compressus. Verh. z.-b. Ges. Wien, xiii, 1335.

Rolfe, R. A. Notes on Oak-galls in the Quercitum of Royal Botanic Gardens, Kew. Ent., xiv, 54.

- Notes on Oak-galls at Kew. Ent., xvi, 29.

Rosenhauer, $W . G$. Die Thiere Andalusiens nach den Resultaten einer Reise zummengestellt. Erlangen, 1856.

$R u d o w, F$. Die Tenthrediniden des Unterharzen nebst einigen neuen Arten anderen gegenden. Stett. Zeits., 1871, 381.

- Revision der Tenthredo Untergattung Allantus, im Hartigschen Sinne. L. c., 1872, 83-94, 137-142.

- Zwei neue Blattwespen. L. c., 217, 218.

- Zur Entwickelung von Nematus gallarum und Nematus Vallisnieri. Ent. Nachr., 1881, 78.

Rothera, G. B. Oak-leaf Hairy Galls (Spathegaster tricolor). Ent., 1879, 23.

Ruthe, J. F. Verzeichniss der von Dr. Staundinger im Jahr 1856 auf Island gesammelten Hymenopteren. S. E. Z., 1859, 305-309.

Rye, E. C. Note on the Flight of Cynips. E. M. M., vii, 255. 
St. Fargeau, Lepelletier de, Ency. méthod, x, 1825. Perga, 65, 66 ; Pristiphora, 205, 206 ; Pterygophorus, 236-7; Ptilia, 237, 238; Selandria, 420 ; Sirex, 438 ; Tarpa, 549; Tenthredo (Dolerus, Cladius, Lophyrus, Schizocerus, Hylotoma, Amasis, Abia, Athalia, Cephus), 566, 577 ; Tenthredinidæ, 577 ; Terebrantia,580 ; Tremex, 696, 697; Urocerata, 769, 770; Xiphydria,790-91; Xyela, 791-2 ; Zaræa, 815.

- Description de trois nouvelles espèces du genre Cimbex. Ann. Soc. Ent. Fr., ii, 454, 1833.

- Remarques sur les caractères donnés par M. Klug au genre Syzygonia. L. c., 456, pl. xvi, 1833.

Saunders, $W$. Notice of the Ravages of a Black Caterpillar upon the Turnips in the South of England. Proc. Ent. Soc., i, 1835, 76.

Saunders, $\boldsymbol{E}$. Is Megalodontes (or Tarpa) plagiocephalus, Fab., really British? E. M. M., xxii, 140.

Say, Th. Description of New North American Hymenoptera, and Observations on some already described. Bost. Journ. Nat. Hist., i, 209-223, 1835 .

- Descriptions of Insects. Keating's Narrative of an expedition to the source of St. Peter's River, under the command of Stephen H. Long, ii, Philadelphia, 1824, 310-320 (Xyela, Xiphidria, Tarpa, Cephus, Hylotoma, Lophyrus, Nematus, Tenthredo, Dolerus).

- A Description of some New Species of Hymenopterous Insects. The Western Quarterly Reporter, ii, 71-73, 1823 (Allantus and Dolerus).

Saxesen, W. Bemerkung über die Fichten-Lyden. S. E. Z., 1840, 15. Schiödte, J. C. Nematus ventralis from Greenland. Berl. ent. Zeits., iii, 144, 1859.

Schlechtendal, D. H. R. von. Allantus consobrinus, Kl., var. Zwickoviensis. S. E. Z., 1873, 88-92.

- Beobachtungen ueber Gallwespen. S. E. Z., 1870, 338 and 376.

- Xestophanes tormentillæ, eine neue Gallwespenart an Potentilla. Ent. Nachr., 1880, 176.

- Ueber Cecidien. J. B. Ver. Zwickau, 1883, 1-18 (Andricus zanthopus, sp. n.).

- Die Gallbildungen (Zoocecidien) der deutschen Gefässpflanzen. Ein Anleitung zum Bestimmen derselben. J. B. Ver. Zwickau, 1890, $1-122$; I. c., 1891, 1-10.

- Eine neue Deutsche Siricide (Macrocephus ulmariæ). Ent. Nachr., iv, 153.

Schöyen, $W . M$. Analytisk oversigt over de Skandinavishe Slæger af phytophage Hymenoptera. Ent. Tidskr., viii, 111-117.

- Supplement til H. Siebke's Enumeratio Insectorum Norvegicorum. Forh. Selsk. Christ., 1887, v, 1-11.

Semenow, A. V. Abia Jakowlewi, sp. n. Hor. Ent. Ross., xxv, 172, 174.

Segvelt, $\boldsymbol{E}$. van. Les Cynipides et leurs Galles, locataires et parasites. Revue des Questions scientifiques, Brussels, 1883, 1-47.

Sells, W. Notes on the Larva of Athalia centifoliæ. Proc. Ent. Soc., 1837, $78-80$.

Shuckard, W. E. Description of a New Species of Sirex (S. duplex) discovered to destroy the Pinus nigra. Charlesworth's Mag. Nat. Hist., i, 630-632. 
Sichel, A. Note sur Abia aurulenta, nouvelle espèce de Piémont. Bull. Soc. Ent. Fr., 1856, vi, 77.

- Liste des Hyménoptères recueillis par M. E. Bellier de la Chavignerie dans le département des Basses-Alpes en 1858. Ann. Soc. Ent. Fr., $1860,2,15$, id ; en Sicile ; en 1859. L. c., $750,757$.

- Observations hyménoptèrologiques (Hylotoma formosa, ๆ). L. c., $1862,119$.

- Abia aurulenta: Fragment d'une revision monographique des Cimbicides de France et d'Europe. L. c. (4), v, 488, 489, pl. x, figs. 2, 3.

Siebold, C. T. von. Ueber das Receptaculum seminis der Hymenopteren Weibchen. Gexms. Zeits., iv, 383-387, 1843. Parthenogenesis. Ent. Nachr., x, 93, 94 .

- Entomologische Notizen (Tenthredo intermedia und coryli). S. E. Z., 1845,325 .

Smith, F. Account of the Natural History of one of the Cynipida which inhabits the Small Flat Galls on the Under Side of Oakleaves Proc. Ent. Soc., 1839, 43.

- Capture of the $\delta$ of Strongylogaster cingulata. L. c., 1852, 17.

- Tenthredo coxalis and Tremex insularis from Borneo. Journal Linn. Soc. Zool., ii, 116 ; l. c. iv, 136, 137 (Cryptocampus, Selandria, Xyphidria).

- Description of a New Genera and Species of Tenthredinidæ in the Collection of the British Museum. Ann. and Mag. Nat. Hist. (3), 1860, 254.

- On the Larva of Croesus septentrionalis, Hemichroa alni, and Eriocampa ovata. Ent. Ann., 1866, 136.

- Notes on some Hymenopterous Insects collected by Mr. Peckolt at Catagallo, South Brazil. Trans. Ent. Soc., 1866, 323 (Dielocerus Ellisii).

- Observations on the Study of Gall-flies (Cynipidæ). E. M. M., iii, 181-183.

- Discovery of a Male Cynips. L. c., v, 298.

- Descriptions of New Species of Hymenopterous Insects of New Zealand collected by C.M. Wakefield. Trans. Ent. Soc., 1876, 473.

- Scientific Results of the Second Yarkand Mission, based upon the Collections and Notes of the late Ferdinand Stoliczka (Tenthredinidæ). Calcutta, 1878.

- Description of New Species of Hymenopterous Insects from New Zealand (Xiphydria flavopecta). Trans. Ent. Soc., 1878, 1.

- Tenthredinidæ and Ichneumonidæ of Japan. Trans. Ent. Soc., 1874, 373-409.

Spinola, M. Hyménoptères recueillis à Cayenne-en 1839 par M. Leprieur. Ann. Soc. Ent. Fr., ix, 130.

- Sur quelques Hyménoptères peu connus, recueillis en Espagne pendant l'année 1842 par V. Ghiliani. Ann. Soc. Ent. Fr., 1843, 111-118.

- Considerazioni sopra i costumi degl' Imenotteri del Genus Sirex, Fabr., e sopra il miglior posto dei Sirceiti nel metodo razionale. Genova, 1843.

- Compte rendu des Hymén. inédits provenants du voyage entomologique de M. Ghiliani dans le Para. Mém. de l’Acad. de Sciences de Turin (2), xiii, 19-94. 
Spinola, $M$. (continued)-

- New Species of Tenthredo. Gay's historia fisica y politica de Chile, Zoology, 1851.

Stein, $\boldsymbol{R}$. von. Ueber den Schaden den Nematus abietum, Htg., oder eine verwandte Art. Sachsen Angerichtet Thorand, vii, 247.

- Beitrag zur Blattwespenzucht. Ent. Nachr., 1879, 204, 217, 244.

- Ein neuer Fall von Parthenogenesis bei den Blattwespen. L. c., 1880, 293.

- Nene oder wenig bekannten Afterraupen. L. c., vi, 246-259.

- Beitrag zur Kenntniss der Nematiden. L. c., 1881, 60.

- Tenthredinologische Studien. Synonymisches. Ent. Nachr., 95105; Drei neue Blattwespen, 1. c., 301-308: 1. Betrachtungen neber die Gruppe der Nematus miliaris, Pz.; 2. Tenthredopsis Wustneri, 349-358.

- Tenthredo velox, F., und Tenthredo bipunctula, Kl. W. E. Z., 1884, 309-313.

- Tenthredinologische Studien. Zur Kenntniss d. Gattung Allantus. Ent. Nachr., xii, 3-9; xi, Die Gattung Cladius, Ill., l. c., 22-29, 33 -40 .

- Neue Afterraupen. W. E. Z., v, 141-151.

- Tenthredinologische Studien: die deutschen Arten der Gattung Allantus. Ent. Nachr., xi, 113-122.

- Tenthredinologische Studien: die Parthenogenesis von Hylotoma rosæ, L. L. c., i, 288-294.

- Tenthredinologische Studien: Synonymische Bemerkungen. L. c., $165-173,209-213$.

- Synonymisches ueber Blattwespen. 'D. E. Z., 1886, 62-64.

- Zwei noch unbekannte Blattwespen Männchen (Pocilostoma pulveratum, Ratz., Perineura insignis, Klug). Wien. ent. Zeit., 137-140.

Stephens, J. $F$. Note on the Ravages of Athalia centifolix. Proc. Ent. Soc., 1836, 77.

- Selandria sericans, a New British Insect, and Lyda inanita. L. c., 1851,85 .

Sundevall. Om Larverne af Tenthredinet slägtet Fenusa. Förhandl. red de Skandin. Naturforsk. in Christiania, 1847, 240, 241.

Taschenberg, $E$. $H$. Schlüssel zur Bestimmung unserer eimheimischen Blatt- und Holzwespen Gattungen und Verzuchniss der beschr. und Ungegend von Halle gefunden A rten. Zeits. f. d. gesammte Naturwiss., $\mathrm{x}, 113-118,1857$.

- Seltene Hymenopteren die 1860 bei Halle gefungen werden. Berl. Ent. Zeit., v, 194, 1861.

- Einige neue sud Europäische Hymenopteren. Zeits. f. d. gesammte Natur., xxviii, 305 (Cephis Helleri, sp. nov.).

- Die dem Wein und Obstbau schädlichen Insecten. Verh. Ver. Pr. Rheinl., 1872, 170-177.

Thomas, $F$. Ueber das durch eine Tenthredinide erzeugte Myeloce. cidium von Lonicera. Verh. But. Ver. Prov. Bradenburg, xxix.

Thomson, C.J. Entomologiska Beiträg. Öfr., 1863, 611-640.

- Opus. Ent., 261, 1870 (Tenthredinidæ).

- Försok till wppstalning och beskrifning af Sveriges Figiter. Öfv., xriii, 395 .

- Öfversigt af Sveriges Cynips-Arter. Opus. Ent., 1877, 778-820. 
Tischbein. Ueber einen Frass der Larve von Nematus Erichsonii. Allgem. Forst- und Yagdzeitung, 1840, 37.

- Verzeichniss der in den Fürstenthümern Lübeck und Birkenfeld von mir bisher aufgefundenen Blattwespen. S. E. Z., 1846, 75$80,113-115$.

- Bestatigung dass Cephus pygmæus und C. spinipes, einer Art angehören. S. E. Z., 1848, 160.

- Hymenopterologische Beiträge. S. E. Z., 1852, 103-108, 137-140; l. c., 1853, 347, 348 (Nematus Wesmaeli).

Tournier, $H$. Descriptions d'Hyménoptères nouveaux et remarques diver'ses. L'Ent. Gen., i, 11, 12 (Aŕge caucasica et A. Beckeri).

Tschek, C. Ueber eine neue Galle auf Eichen (Spathegaster Giraudi). Verh. z.-b. Ges. Wien, 1869, 559.

- Zwei neue Osterreich Cynipiden und deren Gallen. L. c., 1871, 37.

Trail, J. W. H. Oak-galls at Ballater in June, including Andricus amenti, Giraud, New to Britain. E. M. M., x, 85 .

- Occurrence of Galls of Spathegaster vesicatrix, Schlechtendal, at Banchory. E. M. M., x, 85 .

- Occurrence of Galls of Andricus quadrilineatus, Htg., near Aberdeen. E. M. M., $x, 39$.

- Galls and their Gall-makers in Dee. Trans. Nat. Hist. Soc. of Aberdeen, 1878, 65.

- Dimorphism in Oak-gall Makers and in their Galls. Proc. Perth Soc. Nat. Science, 1884, 120-132.

- The Gall-making Hymenoptera of Scotland (exclusive of those that live on Oak). L. c., 1888, 1-19.

- Scottish Oak-galls. Scot. Nat., 302-307.

Uhlmann, $J$. Kleiner Beitrag ueber Eichengallen aus der Nähe Berns. Mittheil. Schweiz Ent. Gesel., 1880, 25-32.

Vallot, $J$. H. Mémoire pour servir des insectes ennemis de la vigne (Hylotoma vitis). Ann. Soc. Royale d'Agric. d. Lyon, iv, 257, 1841.

- Observations sur une espèce de Tenthrèdes qui attaque les branches de chèrrefeuille. Compt rendu d'Acad. d. Sc., Paris, ii, 512, 513.

Vollenhoven, Snellen van. Over de Larve van Cimbex lucorum (betuleti). Tijd. voor Nat. Geschiedenen in Physiol., v, 97-102, 1843.

- Beschrijvingen eeniger Larven van Tenthredinetæ. L. c., 1844, ii, 157-163.

- Drie niewe soorten van inlandsche Hymenoptera. Tijds. voor Ent., 1867, 222 (Nematus pectoralis, Eucoela inflata).

- Nieuwe Naamlyst van Nederlandsche vliesvlengelige Insekten. L. c., xii, 89-118 (Nematus immaculatus, N. catachloris, Dolerus Busæi, Emphytus majalis, Phyllotoma pinguis, Selandria humeralis, $\mathbf{S}$. soror, S. phtisica, Macrophya Klugii, sp. nov.).

- Beschrijving van eenige nieuwe soorten van Bladwespen. Tijd. v. Ent., iv, 1860.

- Naamliesst van Nederlandsche rliesvlengelige Insekten (Hymen. optera). Herklot's Prowstoffen voor eene Fauna van Nederland, ii, $221-283$.

- De Inlandsche Bladwespen in hare gedaantewisselingen levenswegge beschreven. Tijds. voor. Int. :-Cimbex femorata, L., l. c. (2), v, 64-69, pl. iii ; Ent., 1876, 3-8; C. sylvarum, F., xviii, 33-38, pl. iii; Ent., 1879, 171-175; C. axillaris, Pz., v, 49-54; Zool., 9263-9265; C. betuleti, Kl., ii, 63, pl. iii ; Zool., 8012 ; C. lucorum, 
Vollenhoven, Snellen van (continued) -

L., iii (2), 197, pl. viii ; v, 70, pl. iv; Ent., 1875, 5-8; C. lateralis, Leach, vi, 65-71, pl. iv; C. amerinæ, L., iii, 104-108, pl. viii ; Zool., 8789; Abia ænea, Kl., i, 144, pl. v; Hylotoma pullata, Zadd., l. c., xxii, pl. ii ; H. vulgaris, Kl., l. c., xxii, pl, iii ; H. ustu. lata, L., l. c., xxii, pl. iv ; H. rosæ, F., iv, 70-78, pl. ii; Zuol., 1865, 9749-9754; Lophyrus pini, L., iv, 70-78, pl. ii, var. v (2), 71, pl. iv ; Zool., 7887 ; L. similis, Htg., ii, -134, pl. viii ; Zool., 8302; L. rufus, Kl., iv, 65-69, pl. i ; Zool., 1865, 9635-9638; L. virens, Kl., viii (2), 1-5, pl. i; Ent., 18, 1879, 4-8; Cladius difformis, Pz., iii (2), 202-205, pl. ix; Ent., 1875, 26-29; C. uncinnatus, Kl., iv, 84-87, pl. iv ; Zool., 1865, 9833-9835; C. albipes, Kl., vi, 72-75, pl. v ; C. viminalis, Fall., i, 176, pl. x; Zool., 7721; Cryptocampus angustus, H. ; C. mucronatus, Htg., v, 112, 237-254, pl. xii ; Ent., xi, 243-247 ; Nematus septentrionalis, L., ii, 7478,1862 , pl. v; v (2), 75; Zool., 8175; N. varus, Voll., vi, 76-80, pl. vi ; N. latipes, Voll., ii (2), 174-177, pl. viii ; Ent., 1874, 252255 ; N. ccoruleocarpus, Htg., i, 148, pl. vi ; Zool., 7526; N. salicis, L., $\nabla$, 60-64, pl. iii ; Zool., 1865, 9474-7; $N$. ventricosus, Kl., ii, 69 -73, pl. iv ; v (2), 72, pl. iv; Zool., 81, 83; N. consobrinus, Voll., vi (2), 237, pl. x ; Ent., 1876, 247-251; N. perspicillaris (melanocephalus), xxiii, 12 ; N. Wttewaalli, Voll., v, 65, pl. iv ; Zool., 1865, 9549-51; $N$. trimaculatus, Voll., v, 69-71, pl. iv ; Zool., 1865, 9551-9553; N. aurantiacus, Kl., vi, 184-187, pl. xii ; $N$. betula, Htg., vii, 70-74, pl. iii ; N. betularius, Htg., ii (2), 165-167, pl. vi; Ent., 1872, 132-134; N. hortensis, K1., 1, 151, pl. vii ; Zool., 7571; N. aquilgeiæ, Voll., i (2), 202-205, pl.ix ; Ent., 1872, 9; N. vallator, Voll., i, 191, pl. xii ; Zool., 7855 ; N. pallicercus, Htg., vi, 179-183, pl. xii ; N. appendiculatus, Htg., v (2); 55-58, pl. i; Ent., 1875, 76-78; N. solea, Voll., v (2), 59, 60, pl. i; Ent., 1875, 79, 80; $N$. abbreviatus, Htg., iii (2), 206, pl. x; Ent., 1875, 49-52; $N$. virescens, Htg., ii (2), 168, pl. vii ; $N$. crassulus, xiv, 261, pl. xi ; $N$. viminalis, L., ii, 147, pl. x ; Zool., 8473; N. lugdunensis, Voll., vi (2), 243, pl. xi; Ent., 1877, 275-279; N. luridiventris, xiv, 274 -277; Dineura alni, L., viii, 84-88, pl. v; Zool., 55, 24782574; D. rufa, Pz., vii, 89_93, pl. vi; Zool., 1872, 19; Emphytus cinctus, L., viii, 73-77, pl. iii ; Zool., 55, 1993; E. tibialis, Pz., ii, 143-146, pl. ix ; Zool., 8409; $\boldsymbol{E}$. serotinus, Kl., v (2), 61-63, pl. ii ; Ent., 1875, 123-125; Phyllotoma melanopyga, Kl., i (2), 196-201, pl. viii ; Ent., 1872, 70 ; P. tenella, Zad., xviii, 39-42, pl. iv ; Ent., 1879, 264-267; Selandria pusilla, Kl., iv, 79-83, pl. iii ; Zool., $1865,9830-9833$; S. albipes, xiv, 270; S. annulipes, Kl., ii (2), 178 -182, pl. ix ; Ent., 1874, 267-271; S. cereipes, Voll., viii (2), 1315, pl. iii ; Ent., 1879, 149-151 ; S. melanocephala, F., viii, 79-83, pl. iv; Zool., 55, 1871, 2478; S. fulvicornis, 4-6, pl. i, figs. 1-5; S. adumbrata, l. c., xxii, pl. i S. candidata, xiv, 258, pl. x; Ent., xiv, 105; S. ovata, L., vi, 81-86; Pocilosoma pulveratum, xxiii, 7, pl. ii ; Phymatocera aterrima, Kl., v, 55-59, pl. ii ; Zool., 1865, 9471-9474; Athalia spinarum, F., iii, 109, pl. ix ; Zool., 9067-72; Allantus scrophularia, L., iii, 99-103, pl. vii ; Zool., 8653; A. tricinctus, F., i (2), 189-195; Zool., 7718; Tenthredo colon, K1., xviii, 43-49, pl. v; Ent., xiv, 30 ; Macrophya albicincta, Schr., l. c. (2), i, 189-195, pl. vii ; Ent., 1872, 43; Dolerus hæmatodis, xxiii, 1416, pl. iii ; Lyda clypeata, Kl., viii (2), 6-12, pls. ii and iii ; Ent. 1879, 101-106. 
Wachtl, $F$. Mittheilungen ueber neue und wenig bekannten Cynipiden. Verh. z.-b. Ges. Wien, 1880, 539.

- Einige Berichtigungen zu der Abtheilung "Hymenoptera" des von der Zoologischen Station zu Neapel herausgegebenen Jahresberichtes für 1882 . W. E. Z., 1882, 85-87.

- Eine neue Gallwespe (Aulax Kerneri). W. E. Z., 1891, 277-280.

Walker, $F$. Description of some British Species of Anacharis. Ent. Mag., 11, 518-552.

- Observations on the British Uynipides. L. c., 111, 159-170.

- Notes on some Chalcidides and Cynipides in the Collection of the Rev. F. W. Hope. Ann. Mag. Nat. Hist., xix, 227.

- Sirex varipes, sp. nov., in Lord's The Naturalist in Vancouver Island and British Columbia, 1866.

- Note on Oak-apples. Ent., $\mathbf{v}, 431$.

- The Devonshire Gall Cynips Kollari. Ent., ix, 52-54.

- Rose Galls. Ent., 1874, 113.

- Cynips lignicola (= Kollari) on Quercus phellos. Ent., 1875, 4.

- List of Insects inhabiting Oak-apples. Zool., iv, 1454-1457.

- Abstract of Dr. Mayr's Monograph of the Synergi of the Oak-galls. Cistula Entomologica, x, 271.

Walsh, B. D. On Dimorphism in the Hymenopterous Genus Cynips, with an Appendix containing Hints for a New Classification of Cynipidæ, and a List of Cynipidæ, including Descriptions of several New Species inhabiting the Oak-galls of Illinois. Proc. Ent. Soc. Phil., ii, 443-500.

- On Hymenopterous Insects (Tenthredinidæ) inhabiting the Galls of certain Species of Willow. L. c., vi, 229-264, 1866.

Webster, F. M. Adults of the American Cimbex injuring the Willow and Cotton Wood in Nebraska. Ins. Life, i, 228-230.

Westwood, $J$. O. Insectorum Arachnoidumque novorum decades duo (Oryssus Sayii). Zool. Journ., v, 440, 1830.

- Characters of New Genera and Species of Hymenopterous Insects. Proc. Zool. Soc., iii, 51-54, 68-72.

- Notice of the Habits of a Cynipideous Insect Parasite upon the Aph is rosæ, with Descriptions of several other Parasitic Hymenoptera. Mag. Nat. Hist., 1833, 491.

- Insectorum nonnullorum exoticorum e familia Cynipidarum descriptiones. Mag. Zool., 1837 (Leiopteron, Peras, Ibalia).

- Memoirs on Various Species of Hymenopterous Insects : i, On the Economy and Relations of the Genus Xiphydria. Trans. Ent. Soc., iv, 123-136.

- On Hermaphrodite Hymenoptera (Tenthredo cingulata and Cimbex Griffinii). Mag. Nat. Hist., 1838, 393.

- Arcana Entomologica, 1841, 23.

- Capture of Lyda inanita. Proc. Ent. Soc., 1842, 2.

- Note on the Larva of Tenthredo testudinea. L. c., 1848, 9.

- Note on the Larva of Selandria atra, St., and S. æthiops. Gardener's Chronicle, 1848, 524 .

- On Fenusa pumila. L. c., 1849, 597 ; 1851.

- Note on Lyda fasciata. Proc. Ent. Soc., 1851, 15.

- The British Oak-gall. Gardener's Chronicle, 1855, 189.

- Note on Oak-galls. Proc. Ent. Soc., 1855, 119. 
Westwood (continued)-

- On the Caterpillars of the Saw-flies. Ent. Annual, 1858, 122.

- A Monograph of the Saw-flies composing the Australian genus Perga, Leach. Proc. Zool. Soc., 1880, 359.

- Thesaurus Entomologicus Oxoniensis, or Illustrations of new, rare, and interesting Insects for the most part contained in the Collection presented to the University of Oxford by the Rev. F. W. Hope, 1873 (New Cynipidæ, Tenthredinidæ, Cephidæ, and Sinicidæ).

Wilson, T. Tenthredinidae near York. Ent., xiv, 88.

- Cladius viminalis Larvæ Destructive to Nut Bushes. L. c., 188, 216.

$W o o d, J . H$. Notes on the Larvæ of some Tortrices, commonly bred from the Galls of Cynips Kollari, \&c. Ent. M. M., xxv, 217-220.

Woodward, S. On Trichiosoma lucorum, its Pupa, Imago, Habitation. Lond. Mag. Nat. Hist., v, 85, 86, 1832.

Wustnei, $W$. Die bisher in Schleswig-Holstein aufgefundenen Blattwespen. Sehr. Ver. Schlesw., vi, 19-52.

Yarrell, W. Notes on the Economy of an Insect that destroys Turnips (Athalia centifolia). Proc. Zool. Soc., iii, 183, 184, 1835.

- Some Observations on Athalia centifoliz. Trans. Zool. Soc., ii, $67-70,1836$.

Zetterstedt, $J . W$. Nägra nya Svenske Insectarter fundne och beskrifne. K. Vetenskaps Acad. Handlingar Stockholm, 77 (Tenthredo tarsata), 1819.

Buysson, $R$. de. Voyage de ME. Simon au Venezuela. Hyménoptères (Synærema Simoni, sp. nov.). Am. Soc. Ent. Fr., 1892, 59.

Cameron, $P$. The Galls of Mid-Cheshire. Report Man. Micro. Soc., 1891, 65-72.

Hiendlmayr, A. Tarpa spissicornis. Mit. de Münchener Ent. Vereins, ii, 163.

Schaposchnikow, $N$. Strongylogaster cancasicus, sp. nov. Ent. Nach., $1885,181,182$.

Schlechtendal, D. H. R. von. Ist Phyllæus Giraudi, Perris = Macrocephus ulmariæ? Ent. Nach., 1880, 189, 190.

Stein, J. E. P. T. Einige neue dalmatinische griechische und Klein asiatische Tenthredinidær. S. E. Z., 1876, 53.

Vollenhoven. Espèces nouvelles ou peu connues d'Hyménoptères terebrants. Tijd. voor Ent., xxi, 153 (Amasis sanguinea, Macrophya histronica, T.). 


\section{CORRECTIONS AND ADDITIONS.}

VOL. I.

Page 4, sixteenth line from foot, for carnivorous read insectivorous.

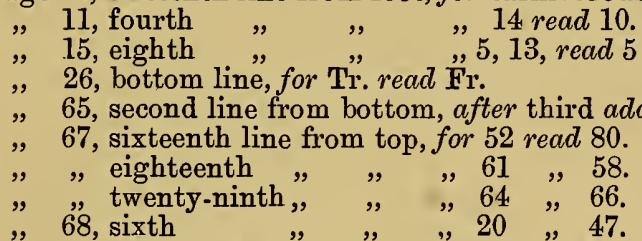

"73, twenty-first line from bottom, for 15 read 25 .

, 78, seventh line fiom top, for Tidj. read Tijd.

"92, first " " ", second and third read third and fourth.

, 135, ninth line from top, for 3,43 read 343 .

160, twenty-second line from top, for base read apex.

" thirty-third " , " 19 read 26 .

, 165, nineteenth " ", " $292,294$.

", 166, thirty-third ", ", ", base and apex read apex

167 , and base.

and base.

," base and apex read apex

204, eighteenth line from top, after Cam. add E.M.M.

224, twenty-second line from top, for xxi read xxii.

231, nineteenth $, " \quad, \quad,(18), \quad$ (19).

" twenty-second ", ", ", (19) " (18).

233 , seventeenth line from bottom, after than add head and.

246 , fourth " " , for saw read sheath.

253, eighteenth " ", nearly read twice.

"267, fourth and thirty-sixth lines from top, for median read dis. coidal cellule.

269, sixth line from bottom, for apex read base.

275 , seventh line from top, for pl. 3 read pl. 9 .

" tenth ", after i add 245.

"281, In the figure of Emphytus perla the transverse median nervure is shown too far from the middle of the discoidal cellule.

, 284, twentieth line from top for black read white.

304 , twenty-second line from top, for spines read spurs. 
VOL. II.

Page 11, fifth line from bottom, for 8 read 10.

22 , fifteenth line from top, for XIV read XIX.

9

,

"9

,

,

"

, sixth

48 , twentieth

50 , third

, fifth

53, eighth

54 , thirteenth

134 , tenth

142 , ninth

168 , tenth

183, sixteenth

185, thirteenth

187, second

, fourteenth ",

2ï, twentieth ",

", twenty-fifth ", 233, eighteenth ,"

" fifteenth "

bottom, for spurs read claws.

top, for pappilosus read papillosus.

", truncated , incised. " after 1. c. add 213 .

bottom, for lugunensis read lugdunensis. top, for stigmata read stigmas.

,for 19 read 7.

bottom, for 20 read 22.

top, for medullaris read medullarius.

„ after pl. xii add 252.

bottom, after 222 add . .

, ", pl. xii add 249.

VOL. III.

Page 11, twentieth line from bottom, for 50 read 59.

" 30 , fourteenth " " , fourth read third.

" 71, fourth ", bottom, del. Perreyia.

"103, sixteenth $\quad " \quad$, for in read on.

"106, fourth " " del. comma after obscure.

"136, top line, for gigas read melanoceras.

" 142, thirteenth line from top, for apterous read apodous.

", 200, third " bottom, add Sweden.

"206, tenth " $\quad$ top, for distinguishes read distinguish.

" 2 "2, tenth

" bottom, for anetnnæ ,, antennæ.

99

,

, , $\quad$ areolet read radial cellule.

\section{VOL. IV.}

Page 4 , twelfth line from top, for Biorhiza read Trigonaspis.

"26, seventeenth line from top, for Quercus cerris read Quercus robur, var. Granbyana.

39, sixth line from bottom, for T. read $\mathbf{P}$.

"108, ninth " top, for 8 read 6 and $6 a$.

", eighth ", bottom, for 9 read 7 .

"' 131, fourteenth" line from top, for Turkey oak read Quercus robur, var. Granbyana. 


\section{4a. ANDRICUS LUCIDUS.}

Cynips lucida, Htg. Germs. Zeits., iv, 405.

Amphilothria lucida, Mayr. Eichengallen, 23, pl. iii, fig. 27. Andricus lucidus, Mayr. Eur. Cyn., 23.

Mosley ('The Naturalist,' Nov., 1892, p. 338) records this species from Whitley Woods, Yorkshire. He describes the galls as of the size of a large pea, in axils of the leaves, covered with bristly projections, each with a red papilla at the end. Mayr describes it as being usually of the size of a cherry, but may reach the size of a walnut. In size it is spherical, in colour pale yellow; the bristles are stiff, fibrous, or stalky, standing out radially. It is polythalamous, hard, the cells without an inner gall.

Hartig describes the insects as fuscous-black; the tegulæ, venter, and feet fuscous-red; the femora on the outer side, the posterior tibia and tarsi black.

Mayr says the third abdominal segment is very distinctly finely punctured, the abdomen castaneous-brown, black above.

Length $2.8-3.8 \mathrm{~mm}$.

The flies appear from March to May. There is only one brood known.

Synergus melanopus and Ceroptres arator are inquilines. 



\section{INDEX TO VOL. IV.}

Synonyms are printed in italics. Generic names in large type.

A.

Allastes marginellas, 161 omissus, 161 succinctus, 161 viennensis, 161

Alternation of Generation, 5

AMIACRONEMATCS, 190, 201

AMERISTRIS, 32, 129

ANDRICES, 33, 36, 74

rstivalis, 106, pl. iv, fig. 5

albopunctata, 100, pl. vi, fig. 4 ambiguus, 95

amenti, 10, 94, pl. vii, fig. 7

antumnaliz, 91

callidoma, 97

cirratus, $9 \overline{7}, \mathrm{pl}$. vi, fig. 1 ; pl. $x$, fig. 8

circulans, 105, pl. v, fig. 1

Clementins, 104, pl. vi, fig. 3

collaris, 68 , 89, pl. $\nabla$, figs. 5 and 50 ; pl. xir, figs. 4 and 4a; pl. zir, fig. 2 corticis, 65, 88; pl. iv, figs. 4 and $4 a$; pl. xrii, fig. 3 curvator, $67,70,89$

cydonix, 71

fecundatrix, 78 ; pl. iii, figs. 3 and $3 a ; \mathrm{pl}$. xiv, figs. 1 and 10

flavicornis, 95

gemmæ, 652, 6.3, 64, 69, 78

gemmatus, 88

glabrusculus, 95

glandium, 37, 69, 76 ; pl. viii, fig. 2

glandulæ, 101, pl. vii, fig. 5
ANDRICCS

globuli, 62,$80 ; \mathrm{p}]$. iv, figs. 1 and $1 a ; 141$

Hartigi, 72,77

inflator, 80

lucidus, 237

Malpighii, 99, pl. vii, fig. 2

marginalis, 96, pl. viii, figs. 5 and 6

ostrens, 77 ; pl. rii, fig. 3; pl. ziii, fig. 9

pilosus, 78

quadrilineatus, 95 ; pl. viii, fig. 3 ; pl. $\mathrm{xv}$, fig. 4

radicis, $2,65,83 ; \mathrm{pl}$. iv, figs. 3 and $3 a ;$ pl. xir, figs. 2 and $2 a$ ramuli, 70 , 91; pl. $\forall i$, figs. 2 and $20 ; \mathrm{pl}$. $\mathrm{rr}$, fig. 1 rafescens, 76

seminationis, 101, pl. $\nabla$, fig. 3 Sieboldi, 16, 65, 86; pl. $\nabla$, figs. 4 and $4 a$; pl. ziv, figs. 3 and 30.

singularis, 71

solitarius, 102, pl. vii, fig. 4

testuceipes, 86

terminalis, commensals in gall of, 11

trilineatus, 8.3

urnæformis, 69

cerrucosu., 95

Aphilothrise, 33, 74

autumnaliz, 92

colluris, 89

globuli, 80

marginalis, 96

quadritineatus, 95 


\section{Aphilothrix}

radicis, 83

Sieboldi, 86

Apophyllus, 32

ARDIS, 174, 176

ATHALIA

ancilla, 186

glabricollis, 186

scutellariæ, 186

A Ulax, 32, 34, 45

abbreviatus, 52

areolatus, 204

artemisix, 25

Brandti, 55

brevitarsis, 54

centaureæ, 51

foveifrons, 53

glechomæ, 5, 25, 46 ; pl. x, fig. 1, gall; pl. xiii, fig. 1, o graminis, 50

hieracii, 25 , 50; pl. ix, fig. 1 ; pl. xi, fig. 1 ; pl. xii, fi. 11 hypochæridis, 25,47 , pl. ix, fig. 5 , gall

jaceæ, 25

Kerneri, 25

Lichtensteini, 25

minor, 25,48

papaveris, 25,48 ; pl. viii, fig. 1 , gall

potentillæ, 52

rhoeadis, 48

Rogenhoferi, 25

salviæ, 25

scabiosæ, 25, 51, 204; pl. xi, fig. 2, gall

scorzoneræ, 25

serratulæ, 25

splendens, 52

tragopoginis, 25

valerianellæ, 25

Aulacomerus

lutescens, 187

Aylax, 45

caninæ, 55

saubaudi, 50

B.

Bathyaspis, 32

BroRHIzA, 32, 36, 37, 117

aptera, 2,25

- On firs, beech and vine, 13

megaptera, 4

\section{BIORHIZA}

renum, 115

synaspis, 67

terminalis, 118, pl. i, fig. 5 ;

pl. xv, fig. $9 a$

BlenNocampa, 173, 177

albipennis, 175

albipes, 180

alchemillæ, 178

alternipes, 178

assimilis, 179

betuleti, 181

bipunctata, 176

cinereipes, 173,178

confusa, 173,178

elongatus, 180

emarginata, 180

geniculata, 179

lanceolata, 186

lineolata, 175

luridiventris, 175

nana, 181

nigripes, 175

pubescens, 175

pusilla, 178

rosarum, 180

sericans, 180

spirææ, 178

sulcata, 176

Breeding gall-flies, 30

C.

CALLIRHYTIS, 33

Ceroptres, 35, 57

arator, 58, 85, 87, 93, 139

cerri, 58

clavicornis, 58

melanoneurus, 58

socialis, 58

Classification, 32

Cladius, 189

Brullei, 188

tener, 188

tristis, 188

viminalis, 187

Collecting gall-flies, 30

CyNipina, 1

CyNIPS, 33, 35, 111

aciculata, 6

amblycera, 63,64

argentea, 67

autumnalis, 92

Brandti, 55

brevicornis, 53 


\section{CYNIPS}

caliciformis, 63

calicis, $63,67,69$

caput-medusæ, $63,67,69$

cerricola, 56

conglomerata, 63, 64, 67

conifica, 62

coriaria, $62,63,67$

corticalis, 86

corticis, 88

curvator, 89

fecundatrix, 78

gemmæ, 78

glechomæ, 47

globuli, 80

glutinosa, 16, 63, 67, 70

Hartigi, 67

hieracii, 50

hungarica, 14, 63, 67

inflator, 80

insana, 14

Kollari, 112, pl, xi, fig. 6

lenticularis, 130

lignicola, 62, 63, 64, 67, 112

lucida, 63,237

marginalis, 96

operator, 6

polycera, 63,67

potentillæ, 52

lineatus, 95

quercus-baccarum, 130

- ramuli, 91

radicis, 83

rosæ, 40

- spinosissimæ, 43

Sieboldi, 86

spongifex, 6

tinctoria, 62, 63, 67, 69

D.

Diastrophus, $33,35,71$

aphidivorus, 74 , pl, xiii, fig. 7 glechomæ 46

Mayri, 25, 53, 73

rubi, $24,25,72$; pl. ix, fig. 2 ; pl, xiii, fig. 6.

- on Pteris aquilina, 13

DiNEURA scabiosæ, 51

despecta, 187

fuscula, 187

mentiens, 187

verna, 187

VOL. IV.
Diplolepis bedeguaris, 40 papaveris, 48

Dryocosmus, 33

Dryophanta, 33, 36, 121 agama, 126, pl, ii, fig. 2 cornifex, 67

disticha, 128, pl, ii, fig. 3

divisa, 127, pl. ii, fig. 4

folii, 122, pl. i, fig. 6

longiventris, 124, pl. ii, fig. 1 scutellaris, 123

Dryoteras, 33

Dolerus, 161

æneus, 167

anthracinus, 164, 165

anticus, 164

atricapillus, 164

brachygaster, 164

brevicornis, 164, 166

cœrulescens, 164

coracinus, 164

coruscans, 166

dubius, 164

elongatus, 167

fissus, $165,166,167$

fulviventris, 163

fumosus, 164

germanicus, 163

gonagra, 166

hæmatodes, 166

Lamprechti, 162

lateritius, 16 ? 163

leucobasis, 165

leucopterus, 167

madidus, 162

nitens, 164, 165

oblongus, 166

palmatus, 161

palustris, 163

picipes, 167

planatus, 166

possilensis, 165

saxatilis, 163

timidus, 164

tinctipennis, 164

tremulus, 162

triplicatus, 162

uliginosus, 162

varispinus, 166, 167

E.

EMPнytus ferruginosus, 183

filicornis, 183

grossulariæ, 183 
INDEX TO VOL. IV.

EMPнттUS

immersus, 170

pallipes, 183

patellatus, 183

perla, 184

tener, 183, 204

togatus, 183

ENEARSIONEURA, 142

ENTODeCTA, 174

ENTROPHA, 33

ErIOCAMPA annulipes, 172, 205

æthiops, 173

cinxia, 173

dorpatica, 171

limacina, 172

ovata, 171

rosæ, 173

umbratica, 171

varipes, 172

ER IOCAMPOIDES, 172

EuвотнR Us, 33, 45

F.

Fenelta, 174

FENUSA, 185

hortulana, 186

pumulio, 186

quercûs, 185

Food-plants, 206

G.

Galls, forms and origin of, 12 jumping, 16

\section{$\mathrm{H}$.}

HoLCOCNEME, 190, 200

Hololexis, 32, 37

eglanteria, 38

HoMOPTÈR ES monoïques, 8

HoploCAMPa ferruginea, 182

apicaris, 182

rutilicornis, 183

I.

Isocolus, 33,45

scabiosæ, 51

J.

Jumping galls, 16
K.

KaLIOSYSPHINGA, 174

L.

LIMASPIS lapsanæ, 25 phœnixopodus, 25

LIODORA, 33

LIPOSTHENUS, 34, 45 glechomæ, 46

LODER US, 161

palmatus, 161

pratorum, 161

trigeminus, 161

vestigialis, 161

LYGAONEMATUS, 199

M.

MACROPHYA Sturmi, 142

Manderstjernia, 129

Mesone URA, 173

Micron maATUS, 190

MoNophaDNUS, 174, 179

$\mathrm{N}$.

Nematus, 189, 200

abbreviatus, 191

albipennis, 198

antennatus, 198

aurantiacus, 196, 198

brachynotus, 195

brevis, 190

cadderensis, 197

canaliculatus, 195

capreæ, 194

carinatus, 194

circumscriptus, 194

cœruleocarpus, 194

conjugatus, 196

consobrinus, 196

crassicornis, 193

croceus, 197

dilutus, 198

fagi, 197

fallax, 195

ferrugineus, 198

flavescens, 197

fulvipes, 190 .

fuscomaculatus, 195

hæmorrhoidalis, 194

hibernicus, 191

hortensis, 196

hypoxanthus, 195 
Nematus

incompletus, 195

lacteus, 195

laricivorus, 191

melanaspis, 195

microcercus, 196

miliaris, 196

mollis, 193

oblongus, 192

olivaceus, 197

pallescens, 194, 197

pallicerus, 194

palliatus, 195

pallipes, 194

ruficeps, 197

stenogaster, 195

strongylogaster, 195

tibialis, 196

turgidus, 195

V-flavum, 196

varius, 197

vicinus, 194

NeUROTERUS, 35, 129

albipes, 64

aprilinus, 138, pl. v, fig. 2

fumipennis, 66,133

læviusculis, 135, pl. i, fig. 2 lenticularis, 130, pl. iii, fig. 1 Malpighii, 130

numismatis, 137, pl. iii, fig. 2 pezizæformis, 135

ostreus, $66,69,77,140$

parasiticus, 81, 141

politus, 141

punctatus, 133

Reaumuri, 137

Schlechtendali, 139

P.

Pachynematus, 190,199

PACHYPROTASIS simulans, 158

PAREOPHORA, 174, 175

Parthenogenesis, 5, 205

Pediaspis, 32

acerina, 25

sorbi, 25

Periclistus, 33, 36, 54

Brandti, 55 ; pl. xiii, fig. 2

caninæ, 43,56

Periclista, 173, 174

Perineura gynandromorpha, 152

Phanacis centaureæ, 25

PHODOPHILUS, 5

PHÆNIXOPUs vimineus, 25
Phylloxera, 8

Phyllotoma fumipennis, 185

Phymárocera, 174

Pecilosoma, 203

candidatum, 176

carbonarium, 171

Fletcheri, 170

guttatum, 171, 203

immersum, 170

impressum, 170

pulveratum, 170

submuticum, 171

Preserving gall-flies, 30

PristiphoRa, 198

Pseudodineura, 174, 187

Pteronus, 190, 201

Pontania, 190, 202

R.

RHADINOCER AA, 174

RHodites bicolor, 16 centifoliæ, 39

dichloceros, 37

eglanteriæ, 12, 24, 38 ; pl. xi, fig. 3 , gall ; pl. xii, fig. 8 , $q$. nervosus, 43 ; pl. xi, fig. 4 , gall; pl. xii, fig. 9 , + .

rosæ, $5,7,23,40$; pl. $x$, fig. 2 , galls ; pl. xii, fig. 10, ठ; $10 a$, rosarum, 43

rufipes, 39

spinosissimæ, 42 ; pl. xi, fig. 5 , gall ; pl. xii, fig. 7 , +

RHOGOGASTERA, 148

S.

SAPHOLYTUS, 33,56

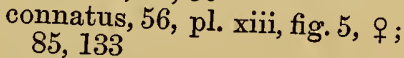

Haimi, 56

undulatus, 5, 6

Sciaphila communana, 132

Sciopteryx costatus, 204

SCOLIONEURA, 181

SELANDRIA analis, 169

aperta, 168, 178, 203

candidata, 176

cinereipes, 168, 203

serva, 168, 204

stramineipes, 169

Smell of galls, 15

Spathegaster, 33, 129 
Spathegaster

albipes, 135

baccarum, 2, 67, 70, 71, 130

glandiformis, 71

interruptor, 130

nervosus, 71

punctatus, 133

tricolor, $67,70,71$

vesicatrix, 137

STrombocerus delicatulus, 167

Strongylogaster filicis, 167 cingulatus, 167

SyNERGUS, 34, 59

albipes, 67, 91, 129, 132, 135 apicalis, 64 , pl. xii, fig. 2 ; 79 ,

$85,87,92,132,137$

australis, 66

bispinus, 69

carinatus, 71

connatus, 56

erythroneurus, ј6, 64, 67

evanescens, 62

facialis, 69 , pl. xii, fig. 1 ; 91 ,

93, 96, 132, 135

flavicornis, 66

flavipes, 62

Hayneanus, 62

immarginatus, 64

incrassatus, $64,87,88$

Klugii, 71

luteus, 71

melanopus, 62, pl. xii, fig. 5 ; 79

nervosus, 68 , pl. xii, fig. $4 ; 90$, 92

nigricornis, 68

nigripes, 66

orientalis, 62

pallicornis, 66, 129

pallidipennis, 62

pallipes, 90

radiatus, 70, 91, 93, 132

Reinhardi, 63

ruficornis, 41, 62, 81, 92, 132

socialis, 62

thaumacera, 71, 91, 129, 135

tibialis, 68

tricolor, 134

tristis, 68,78

Tscheki, 65, 78, 131, 134, 136,

138, pl. xii, fig. 6

variolosus, 92

varius, 134

vulgaris, $69,76,81,85$

SyNopHRUs, 33

Synopsis of British galls, 26

T.

TAXoNus

agrorum, 169

albipes, 170

equiseti, 170

Eletcheri, 170

glabralus, 170

glottianus, 170

sticticus, 170

TENTHREDO, 142

arctica, 147

atra, 146

aucupariæ, 150

balteata, 146

biguttata, 144, 145

coryli, 144

dispar, 146

flava, 143

gibbosa, 150

gynandromorph $\alpha, 152$

ignobilis, 154

intermedia, 144

Lachlaniana, 146

livida, 144

mandibularis, 147

mesomela, 147

obsoleta, 147

olivacea, 148

poecila, 146

punctula, 144

punctulata, 148

rufiventris, 145

solitaria, 144

velox, 145

viridis, 149

TENTHREDOPSIS, 150

albomaculata, 157

arrogans, 155

Braunsii, 154

brevispina, 150, 151

caliginosa, 153

conjungens, 154

Coqueberti, 152, 154

cordata, 151, 153

dorsalis, 152, 155

一, Lep., 158

dorsivittata, 157

dubia, 154

elegans, 153

excisa, 152

femoralis, 153

flavomaculata, 152

Friesei, 156

fulviceps, 152, 156 
TENTH REDOPSIS

gynandromorpha, 152

histrio, 155

ignobilis, 154

inornata, 156

indocilis, 157

limbilabris, 154

lividiventris, 152,156

microcephala, 153

nassata, 153, 157

nigriceps, 152,156

nigronotata, 152, 153

ornata, 155

pavida, 156

picticeps, 152, 154

Raddatzi, 152, 157

Saundersi, 157

scutellaris, 151,152

semirufa, 152, 155

sordida, 157,158

stigma, 155

tiliæ, 151

Teras, 33
Teras

amentorum, 91

Thomsonia, 150, 152

gynandromorpha, 152

TrIgONaspis, 33, 34, 114

megaptera, 115 ; pl. i, fig. 4 ;

pl. $x v$, fig. 7

ToMosTetH US, 174, 177

TrinaX continua, 168

femoralis, 168

macula, 168

mixta, 168

Sharpi, 168

$\mathrm{X}$.

XeNOPHANES, $34,36,52$

XeNOPHANES brevitarsus, 25,54 ;

pl. ix, fig. 3 , gall; pl. xii, figs. $12,12 a$

foveicollis, 25,52

potentillæ, 25,52 , pl. xii, fig. 3 , $, 3 a, 3 b$; pl. xvi, fig. 1 , gall

\section{INDEX TO NAMES OF PARASITES AND HOSTS.}

Braconide, 12

BrACON immutator, 205

Callimone mutabilis, 138

Chalcid in imago of Biorhiza aptera, 11

Chalcididæ, works on, 11

Cirrospilus arcuatus, 49

DeсAтоMA biguttata, 91, 129, 131 hieracii, 51

Neesi, 82, 91, 93

quercicola, 73

Diplolepis gallæ-pomiformis, 70

ELACHestus petrolatus, 91

ENCYRTUs ruborum, 73 zephyrinus, 53

ENTEDON cecidomycarnus, 91

flavomaculata, 131

leptoneurus, 79

scianurus, 91

ESCHATOCERUS, 5
EULOPHUS inunctus, 39

lævissimus, 91

metallicus, 91

nitidulus, 53

Eupelmus, 10

annulatus, 91, 132

annulicornis, 73

bedeguaris, 41

brachypterus, 47

Degeeri, 10, 41, 47

Geeri, 205

Eurytoma, 10, 12

abrotani, $41,53,73$

æthiops, 41, 138

curta, 138

cynipsea, 48

diastrophi, 73

flavoscapularis, 51

nodularis, 41

quercicola, 73 
EuRYtoma

rosæ, $39,41,78,79,81,84,87$,

129,132

rufipes, 47,53

semirufa, 93

signata, 51, 79, 129, 131

vagabunda, 10

verticillata, 90

HeMITELES, 16

imbecillus, 39

luteolator, 41

HolaspIs militaris, 49

ICHNEUMONID E, 12

Lochites papaveris, 49

Megastigmus, 10

dor'salis, $79,81,82,85,87,92$, 131

transversus, 43

MesopolobUs fasciiventris, 79 , 91,129

OLIN $, 10,12$

debilis, 93, 94

gallarum, 93, 129

trilineata, $79,87,96$

Origosten Us stigma, 39,41

Oligosthenus tibialis, 53

ORthopenma luteolator, 39

ORYMUS, 10

papaveris, 49

Pezomachus gallarum, 131

diastrophi, 47

papaveris, 49

potentillæ, 53

Platymesopus Erichsoni, 91 tibialis, 138

Pledrotropis sosarmus, 131, 138

Porizon halpuirus, 41

Pteromalus, 12

Andrewii, 51

aurantiacus, 51

bisignatus, 78

cordairii, 91

cynipis, 205

sp., 135

dissectus, 82, 91, 94, 131

eminens, 44

Erichsoni, 82, 91

fascicularis, 205

festivus, 41

fuscipalpis, 41

glechomæ, 47

immaculatus, 132

incrassatus, $39,43,73$

inflexus, $39,41,43,44$

jucundus, 91
Pteromalus

meconotus, 91

naucus, 205

quercinus, 84

neostatensis, 39

pilosus (pilosellus ?), 39, 41

Ratzeburgi, 93, 94

planiusculus, 51

Saxesenii, 91, 129

tibialis, 131

RAPTROCNEMIS papaveris, 49

Siphon URA brevicauda, 53, 129

chalybea, 81

Schmidti, 129

variolosa, 205

viridiænea, 91

Srntomaspis caudatus, 79,90 , 129,131

cyaneus, 129

dubius, 91

incrassatus, 84

regius, 129

vulgaris, 79

Systole castaniventris, 51

Telenomus phalænarum, 91

Tetrastich US, 12

atrocæruleus, 132

aurantiacus, 43

leptoneur'us, 39

longicaudatus, 39

obtustatus, 39,44

quercûs, 51,84

rosarum, 39,43

ToRYMINA, 12

ToRYMUs abbreviatus, 129

abdominalis, 91, 129, 132

amœnus, 84

ater, 53

auratus, $39,82,91,93,96,129$, 131

chlorinus, 51

chloromerus, 129

cingulatus, 47

congener, 39

corticis, 88

cynipoides, 73,84

difficilis, 39,43

eglanteriæ, 39

erucarum, 84

euchloris, 51

fuscicrux, 131, 138

glechomæ, 47

globiceps, 53

hibernans, 131, 136

hieracii, 51 
Torymus

incertus, 132

inconstans, 79

longicaudis, 4.1

macropterus, 41, 43, 44, 73

nobilis, 84,87

purpurascens, 41

radicis, 84

regius, $79,81,132$

rosarum, 41,47
TORYMUS

rubi, 51,73

sodalis, 131, 134, 136

splendens, 47

sp., 135

tipularum, 39

variolosus, 129

viridis, 39

TRYPhON, 1

\section{INDEX TO PLANT NAMES.}

ACER pseudo-platanus, 25

ÆGGOPODIUM podagraria, 143

ALnus glutinosa, 145

incana, 145, 149

ANThRISCUS sylvestris, 151

ARCTidm lappa, 147

Artemisia, 25

campestris, 150, 151

Beech, 13

CareX, 165

Centaurea jacea, 25

paniculata, 25

salamatina, 25

scabiosa, 25,51

CirCAA lutetiana, 149

Cistus, 13

CoRyuUs avellana, 144, 148

Cratergus, 182

Cxdonia vulgaris, 172

Uytisus capitatus, 25,50

FAGUS, 25

Firs, 13

GALIUM aparine, 179

GLEchома hederacea, 25

Grass, 165, 166

HIERACI UM, 13 boreale, 25,50 sylvaticum, 50

HYPOCHERIS radicata, 25, 48

Juncus, 150 glomeratus, 162

LAMrUM album, 146

LAPSANA communis, 25

LINARIA vulgaris, 25,50

LONICERA, 144

LYTHRUM salicaria, 170

Mentha aquatica, 146
Mrosotis, 203

NEPETA glechoma, 46 pannonice, 25

Papaver dubius, 49 rhœas, 25,49

Petasites officinalis, 147

Pimpinella saxifraga, 150

Pinus, 25

Polygondm, 203 persicaria, 147,170

Populus tremula, 172

Potentilla argentina, 25, 53, 73 reptans, 25,53 tormentilla, 25,54

PrUnUs spinosa, 175

Pteris aquilina, 13, 25, 144, 145, 146,169

QUERcus Farnetto, 26

glandulifera, 26

lusitanica, 26

- var. infectoria, 26

- var. Turneri, 26

tinctoria, 6

toga, 26

RANUNCULUS acris, 169 repens, 149

RHUs lucidum, 5

Rosa, 144, 180 arvensis, 44 canina, 24, 39, 44 caucasica, 44 centifolia, 39 eglanteria, 24, 39, 44 rubiginosa, 24, 39, 44 spinosissima, 24, 39

RUBUs cæsius, 73 fruticosus, 73 


\section{RUBus}

idæus, $73,169,188$

SALIX aurita, 145, 172

caprea, 144, 145, 149

helix, 145, 149

triandra, 184

Salvia officinalis, 25

Sarothame Us scoparius, 150

Scorzonera humilis, 25

Serratula heterophylla, 25

Sorbus aucuparia, 25, 144, 149

SPIRAa ulmaria, 145, 178

Stellaria holostea, 149
TrAgopogon major, 25 orientalis, 25

TRITICUM, 13 repens, 25,51

Tussrlago farfara, 147

VACCINIUM myrtillus, 172, 193 uliginosum, 172

VALERIANELLA olitoria, 25

VIBURNUM opulus, 144

Vine, 13, 204

VIOLA tricolor, 203

Vrisis, 25 



\section{PLATE I.}

Fig. 1.-Galls of Neuroterus tricolor. Fig. 1 a.- ", Neuroterus fumipennis. Fig. 2.- " Neuroterus albipes. Fig. 2 a.- " Neuroterus lævinsculis. Fig. 4.- " Trigonaspis megaptera. Fig. 5.- " Biorhiza terminalis. Fig. 6.- " Dryophanta folii. Fig. 7.- " $\quad$ Trigonaspis megaptera. 
Phyto. Hymen. iv. Plate 1

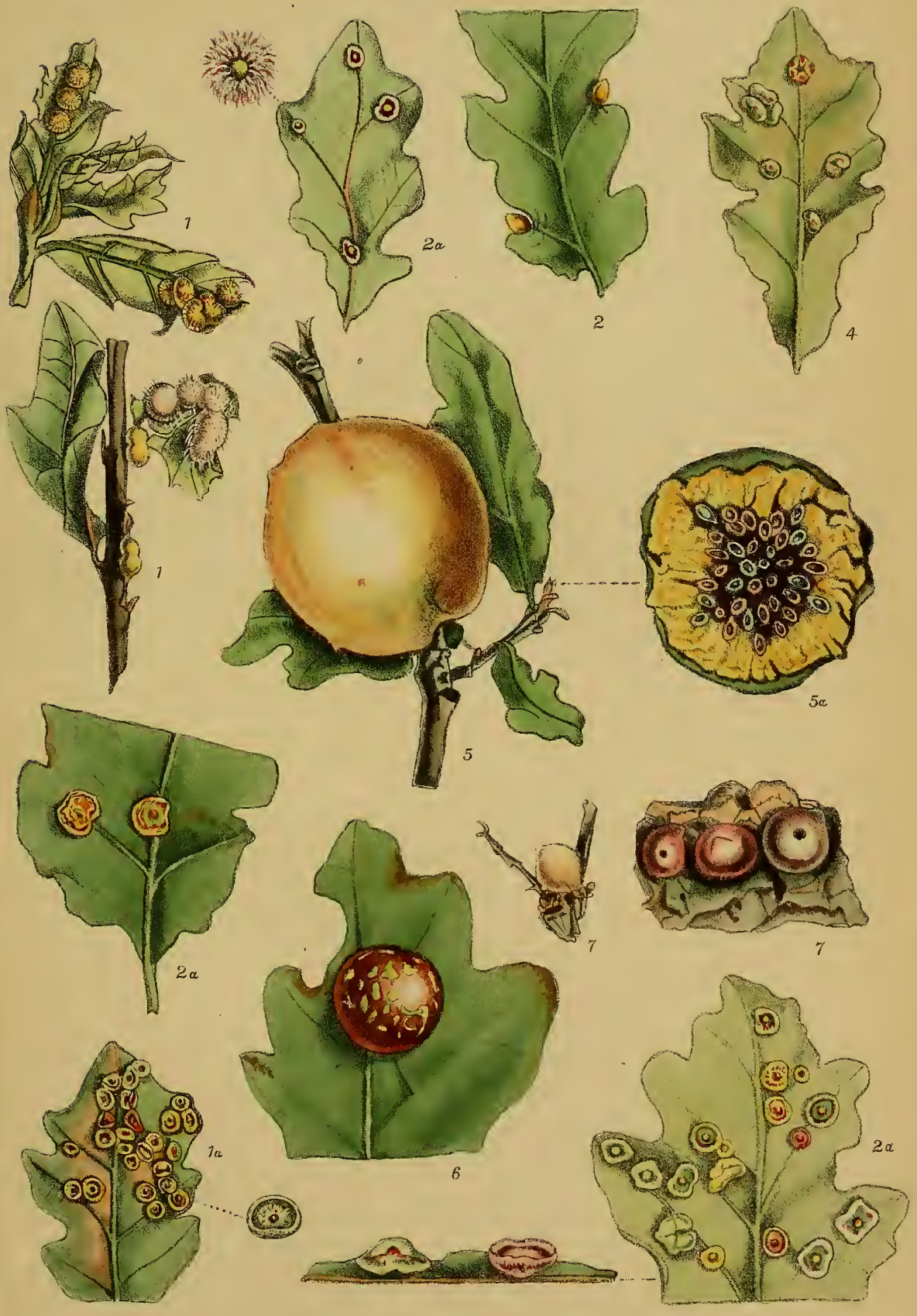




Phyto. Hymen. iv. Plate 2.

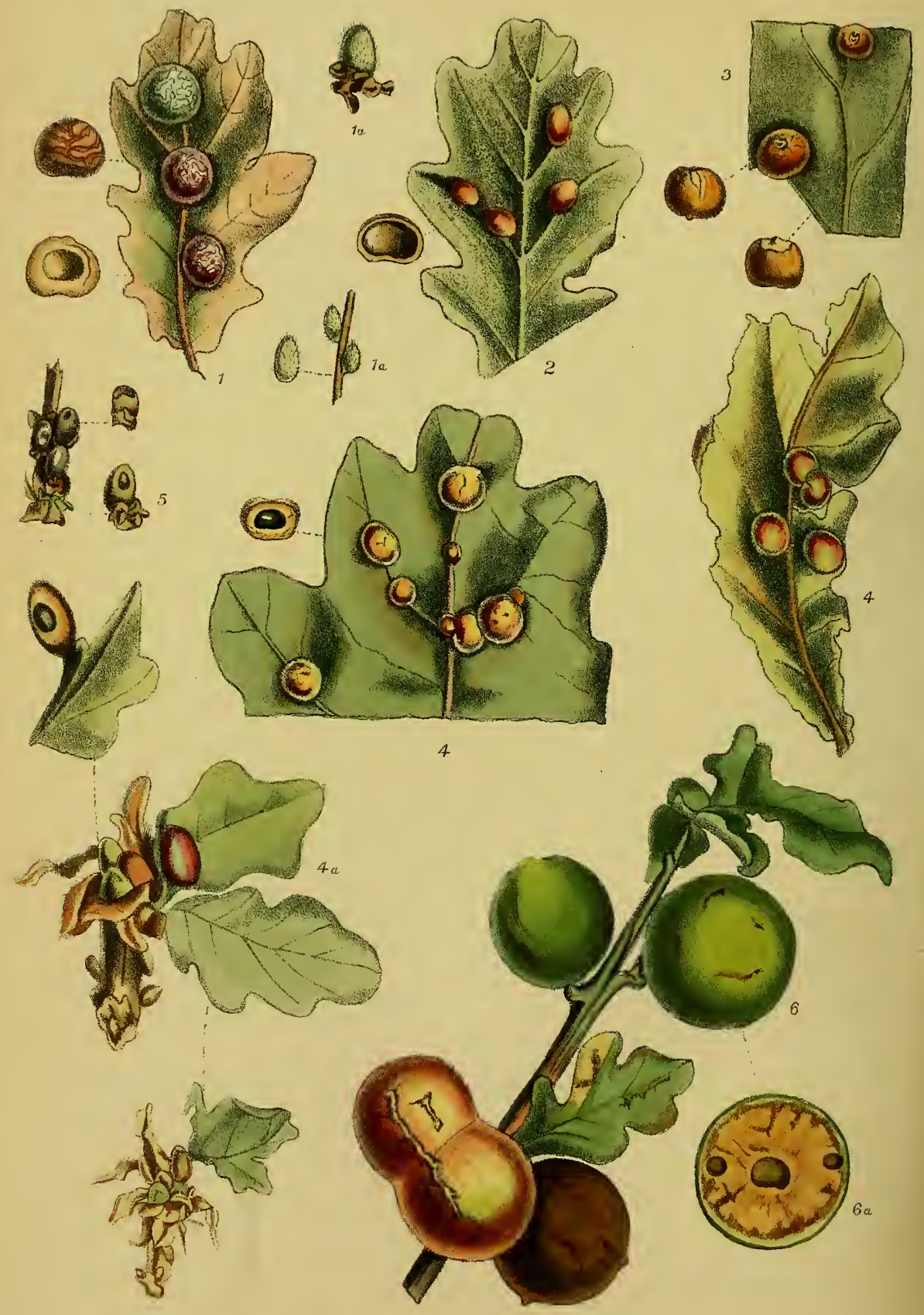




\section{PLATE II.}

Fig. 1.-Galls of Dryophanta longiventris. Fig. 1 a.- " Dryophanta similis. Fig. 2.- " Dryophanta agama.

Fig. 3.- " Dryophanta disticha.

Fig. 4.- " Dryophanta divisa.

Fig. 4a.- " Dryophanta verrucosa.

Fig. 5.- " Dryophanta Taschenbergi. Figs. 6, 6 a.-Galls of Cynips Kollari. 




\section{PLATE III.}

Fig. 1.-Galls of Neuroterus lenticularis. Fig. 1 a.- ", Neuroterus baccarum.

Fig. 2.- " Neuroterus numismatis.

Fig. 2 a._ " Neuroterus vesicatrix.

Fig. 3.- ", Andricus fecundatrix.

Fig. 3 a.- ", Andricus pilosus.

Fig. 4.- " Biorhiza terminalis. 
Phyto. Hymen. 1v. Plate 3.
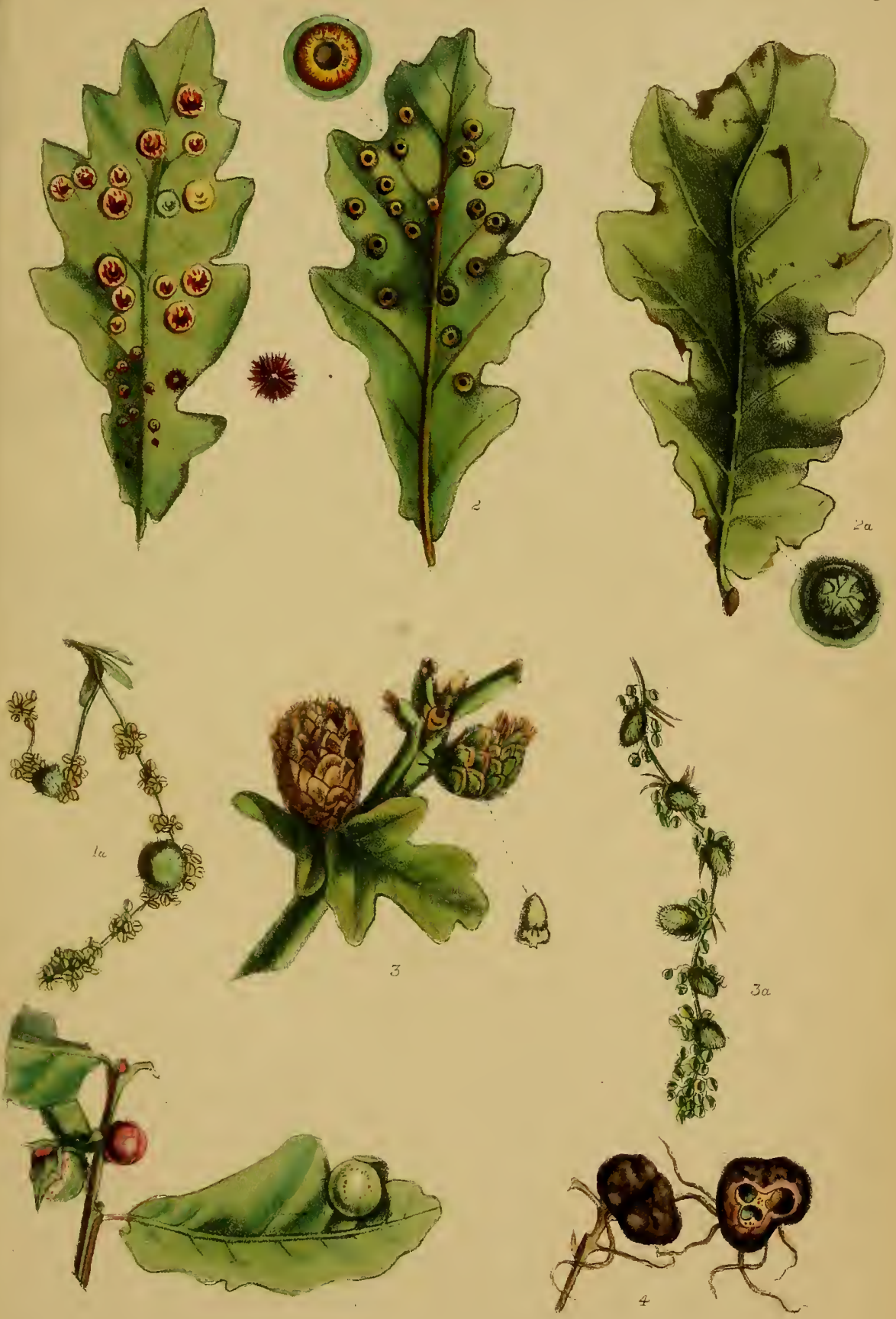




\section{Phyto. Hymen. iv. Plate 4.}
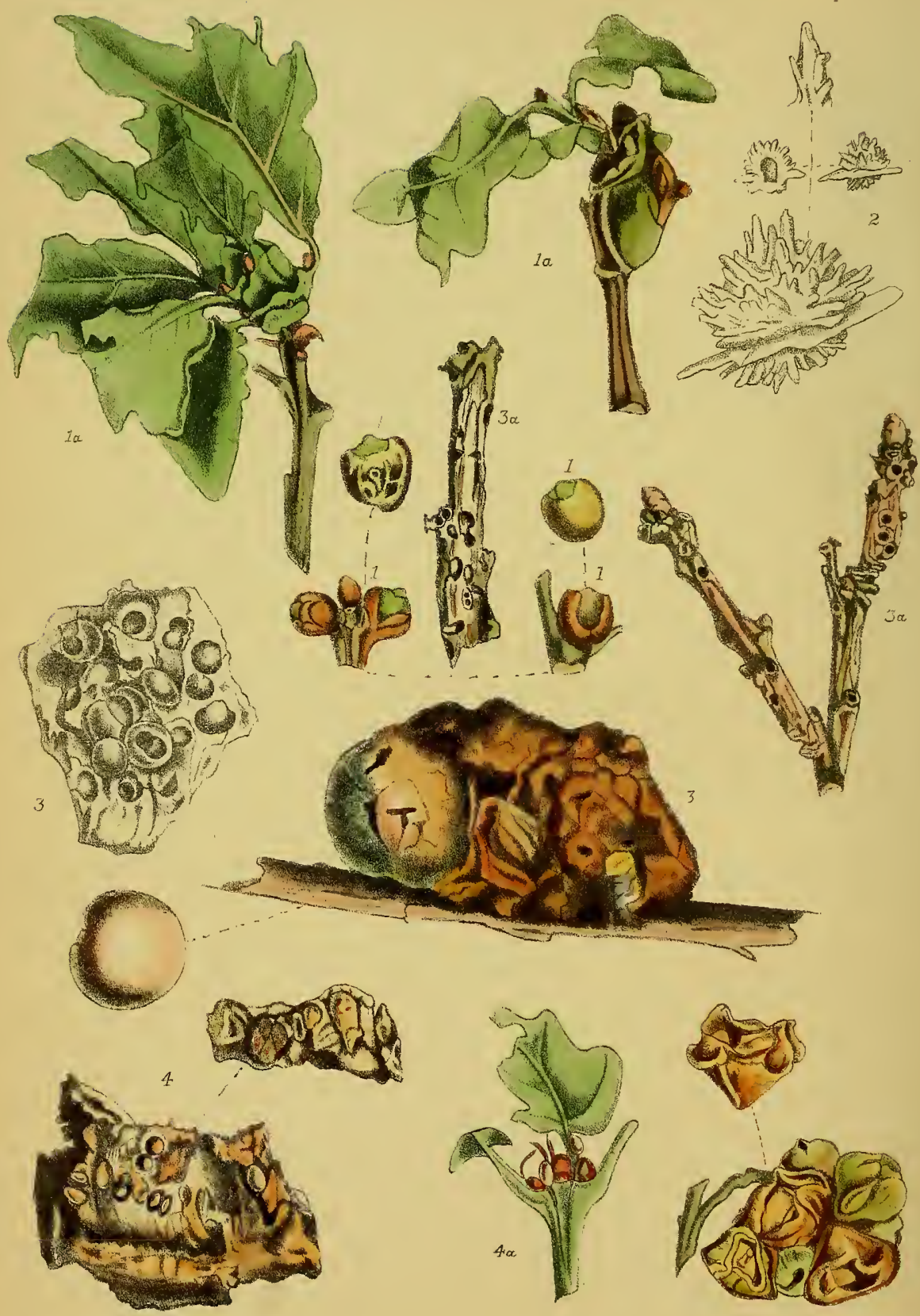


\section{PLATE IV.}

Fig. 1.-Galls of Andricus globuli.

Fig. 1a.- ", Andricus inflator.

Fig. 2.- ", Andricus gemmæ, Gir.? (after Ormerod).

Fig. 3.- „, Andricus radicis.

Fig. 3 a.- ", Andricus trilineatus.

Fig. 4.- ", Andricus corticis.

Fig. 4a.- ", Andricus gemmatus.

Fig. 5.- " Andricus æstivalis. 




\section{PLATE $\nabla$.}

Fig. 1.-Galls of Andricus circulans.

Fig. 2.- " Neuroterus aprilinus.

Fig. 3.- " Andricus seminationis.

Fig. 4._ " Andricus Sieboldii.

Fig. 4a.- ", Andricus testaceipes.

Fig. 5.- " Andricus curvator.

Fig. 5 a.— " Andricus collaris. 
Phyto. Hymen n. Plate 5.

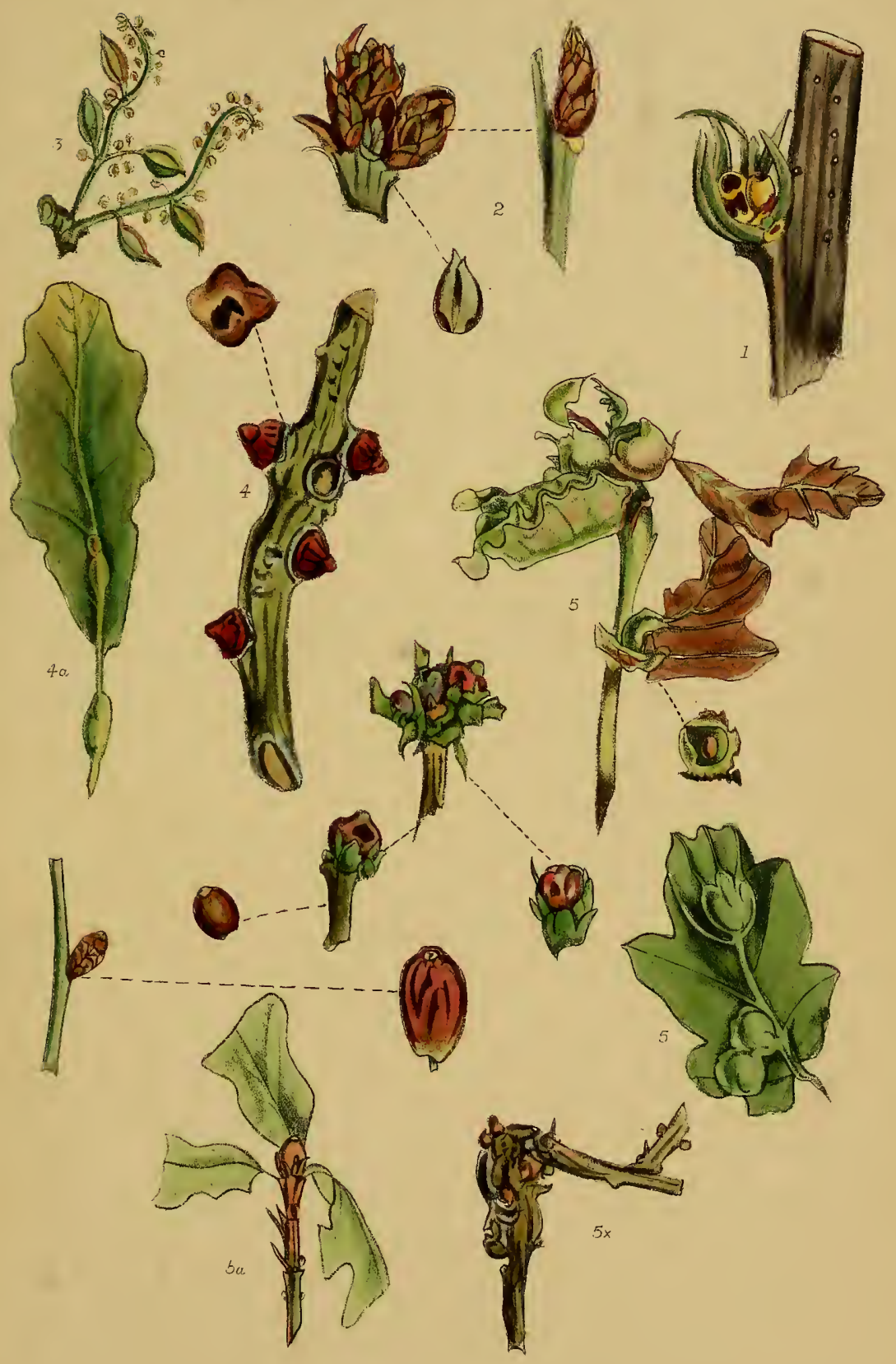






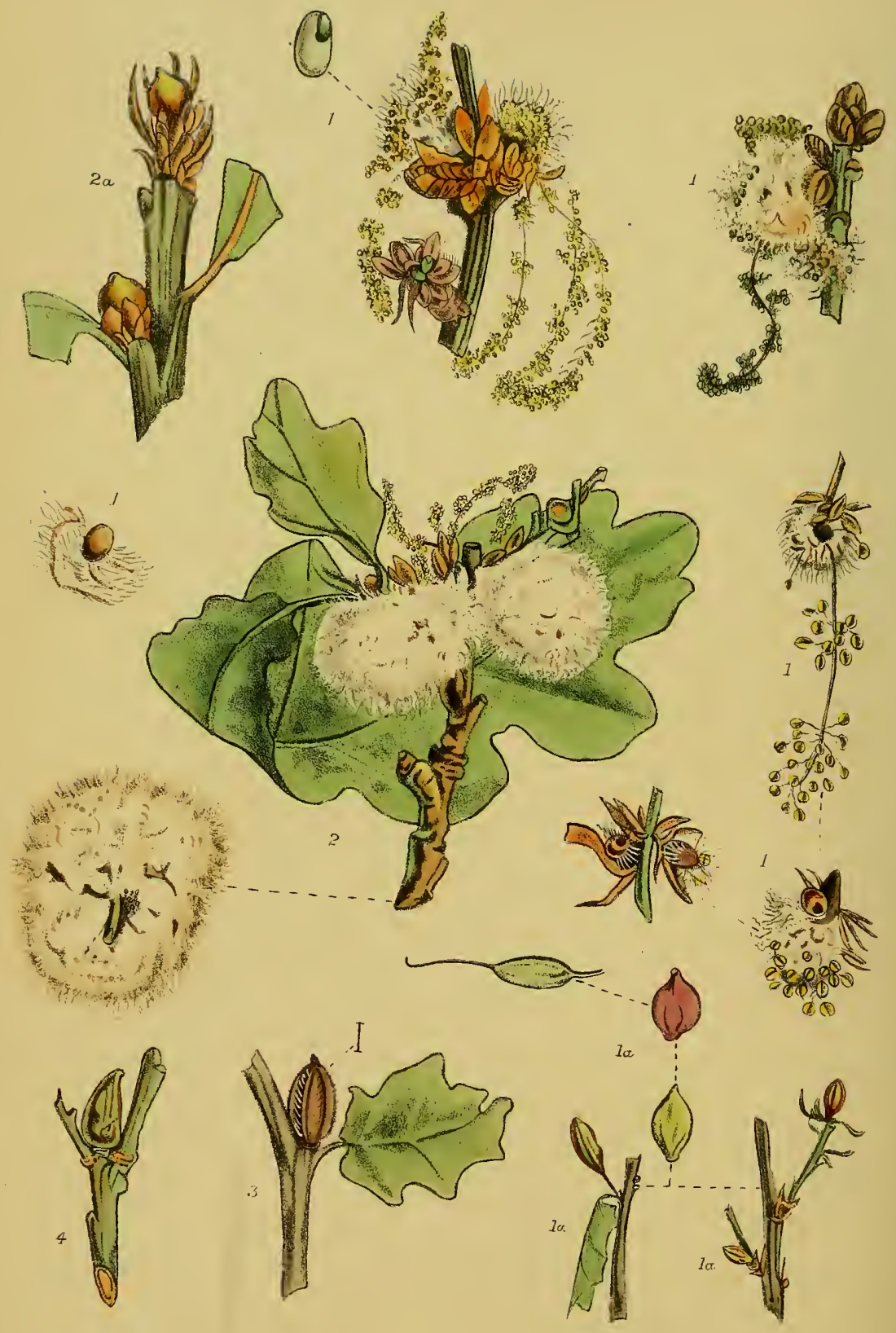




\section{PLATE VI.}

Fig. 1.-Galls of Andricus cirratus.

Fig. 1 a.- " Andricus callidoma.

Fig. 2.- ", Andricus ramuli.

Fig. 2a.- ", Andricus autumnalis.

Fig. 3.- " Andricus Clementinx.

Fig. 4.- " Andricus albopunctata. 




\section{PLATE VII.}

Fig. 1.-Galls of Andricus nudus.

Fig. 2.- " Andricus Malpighii.

Fig. 3.- " Andricus ostreus.

Fig. 4.- " Andricus solitarius.

Fig. 5.- " Andricus glandulx.

Fig.6.- " Neuroterus Schlechtendali.

Fig. 7.- " Andricus amenti. 
Phyto. Hymen iv Plate 7.
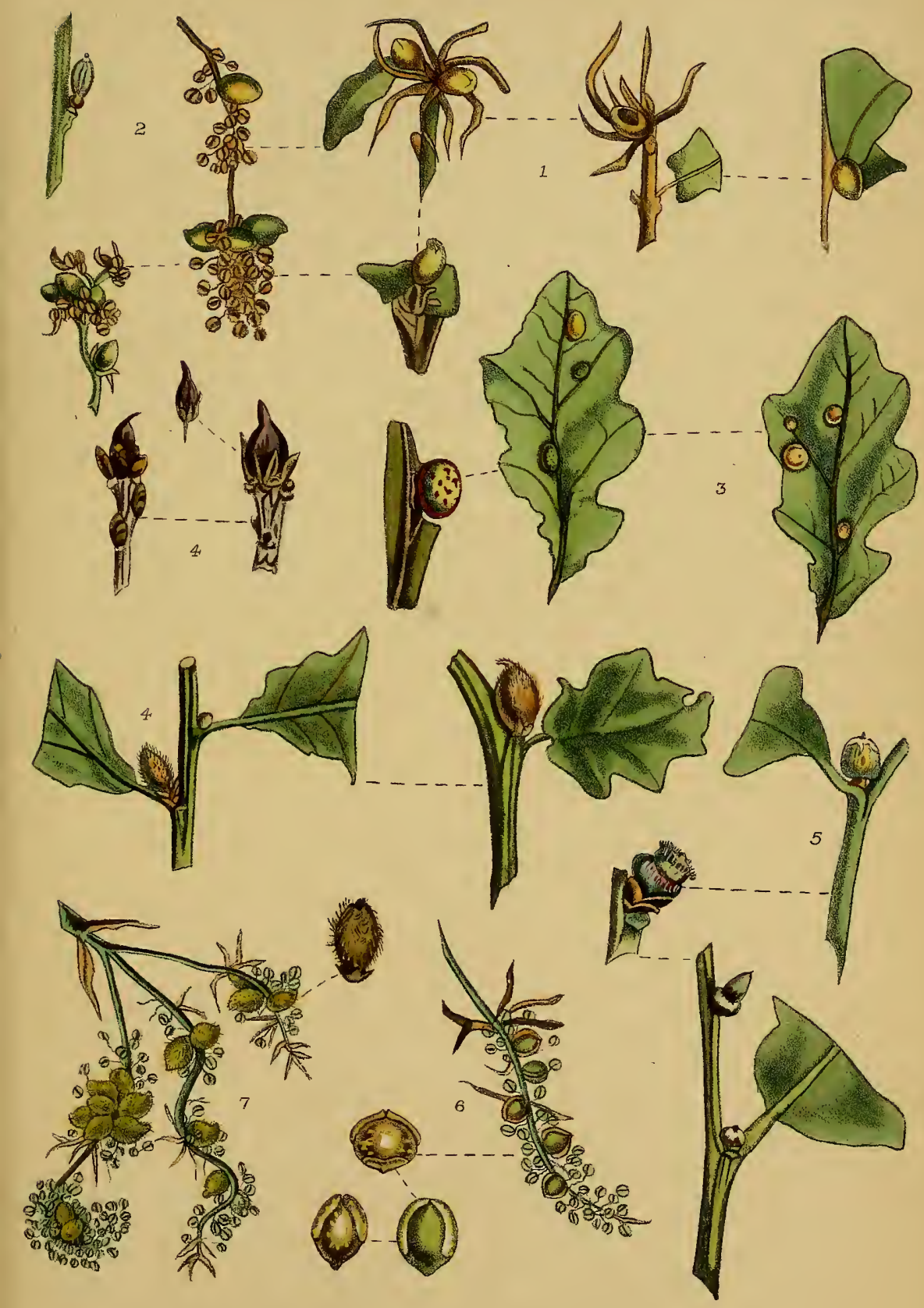


Phyto. Hymer jv, Plato 8

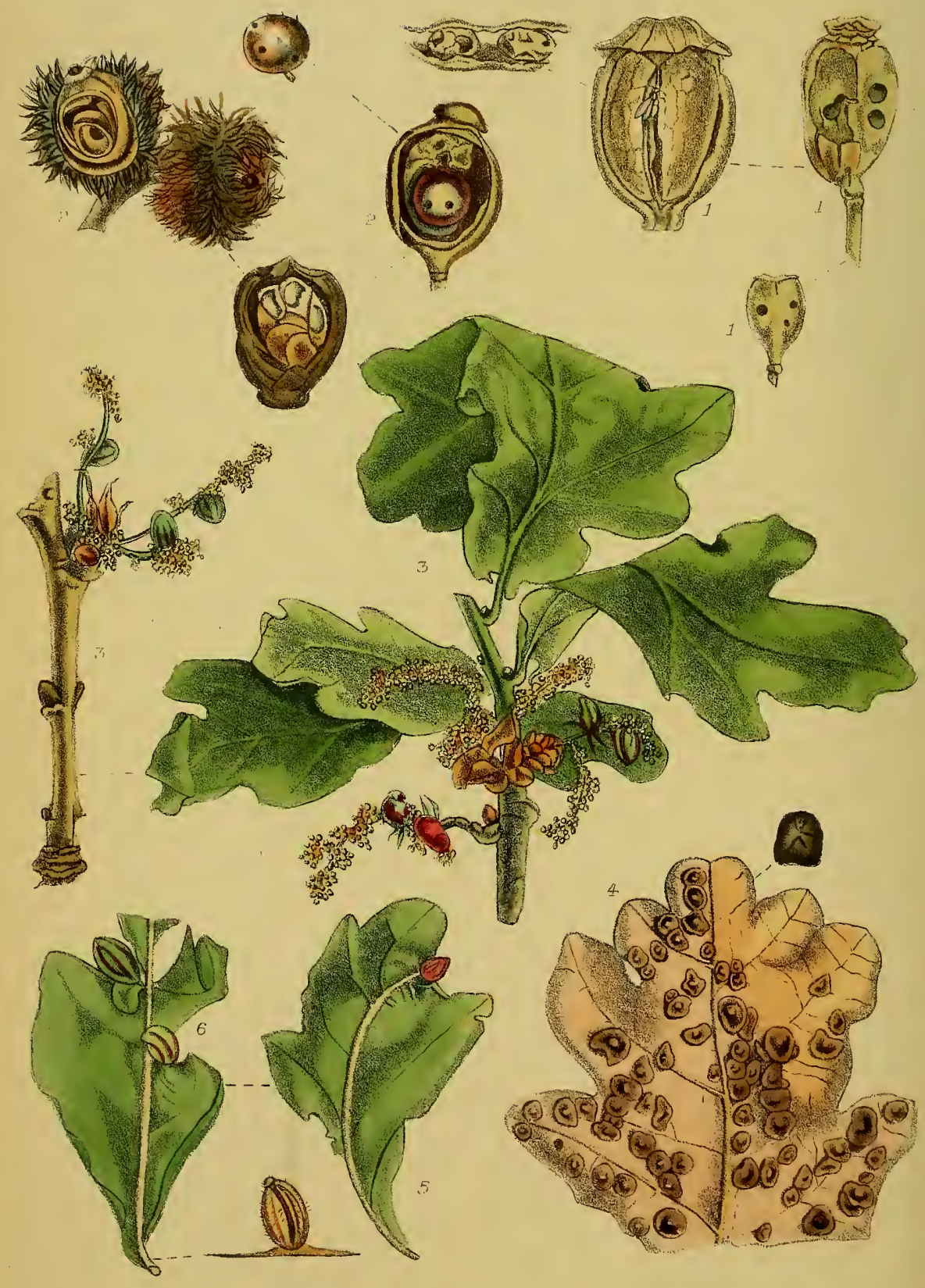




\section{PLATE VIII.}

Fig. 1.-Galls of Aulax papaveris.

Fig. 2.- , Andricus glandium.

Fig. 3.- " Andricus quadrilineatus.

Fig. 4.- " Neuroterus lenticularis (on

Turkish oak).

Figs. 5, 6.- „ Andricus marginalis. 




\section{PLATE IX.}

Fig. 1.--Galls of Aulax hieracii.

Fig. 2.- " Diastrophus rubi.

Fig. 3.- " " Xestophanes brevitarsis.

Fig. 4.- " " Aulax, sp.? on Lathyrus macrorrhizus.

Fig. 5.- " Aulax hypochæridis. 


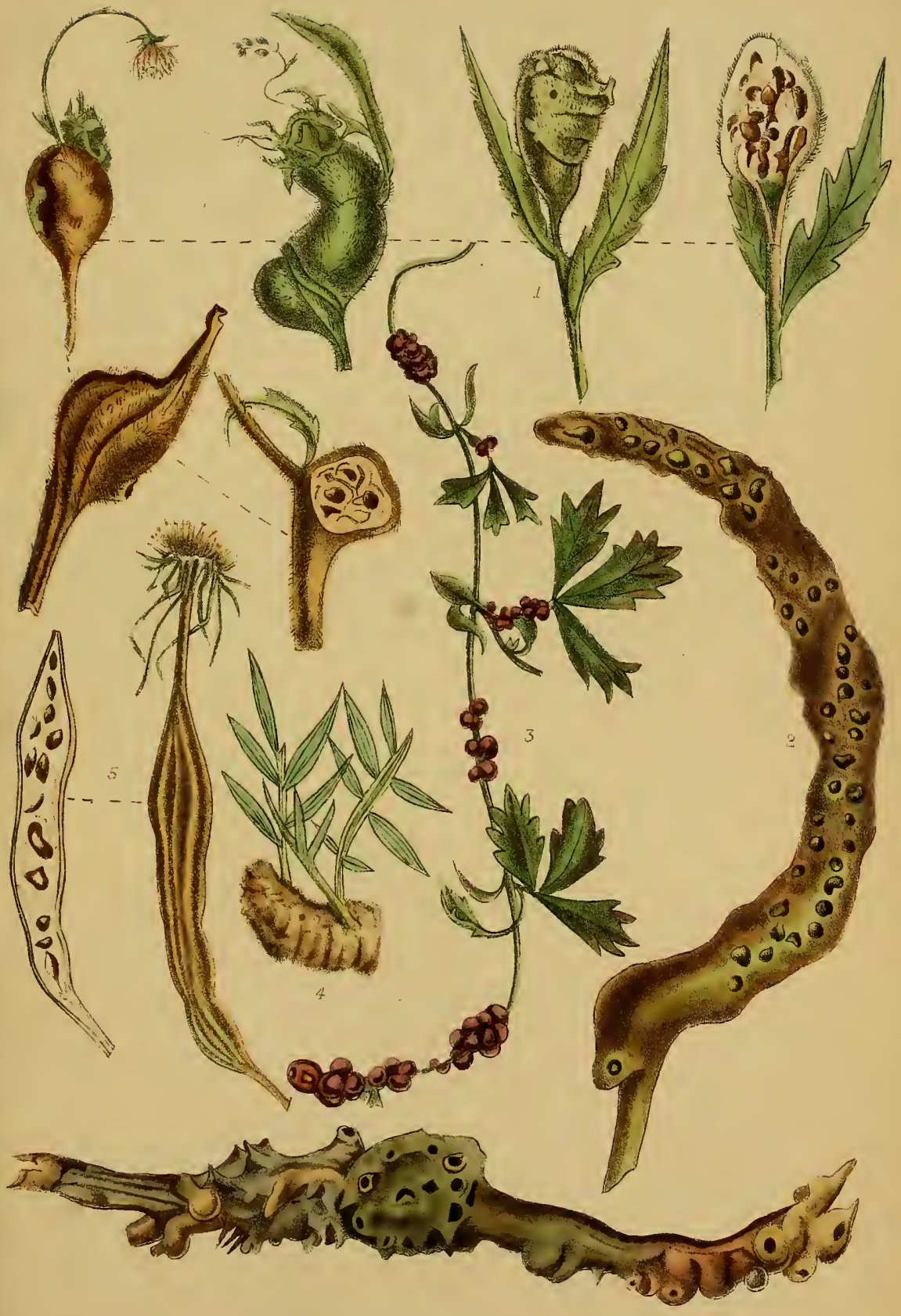






\section{PLATE X.}

Fig. 1.-Galls of Aulax glechomæ.

Fig. 2.- " Rhodites rosæ. 
Phyto Hymen iv Plate 10
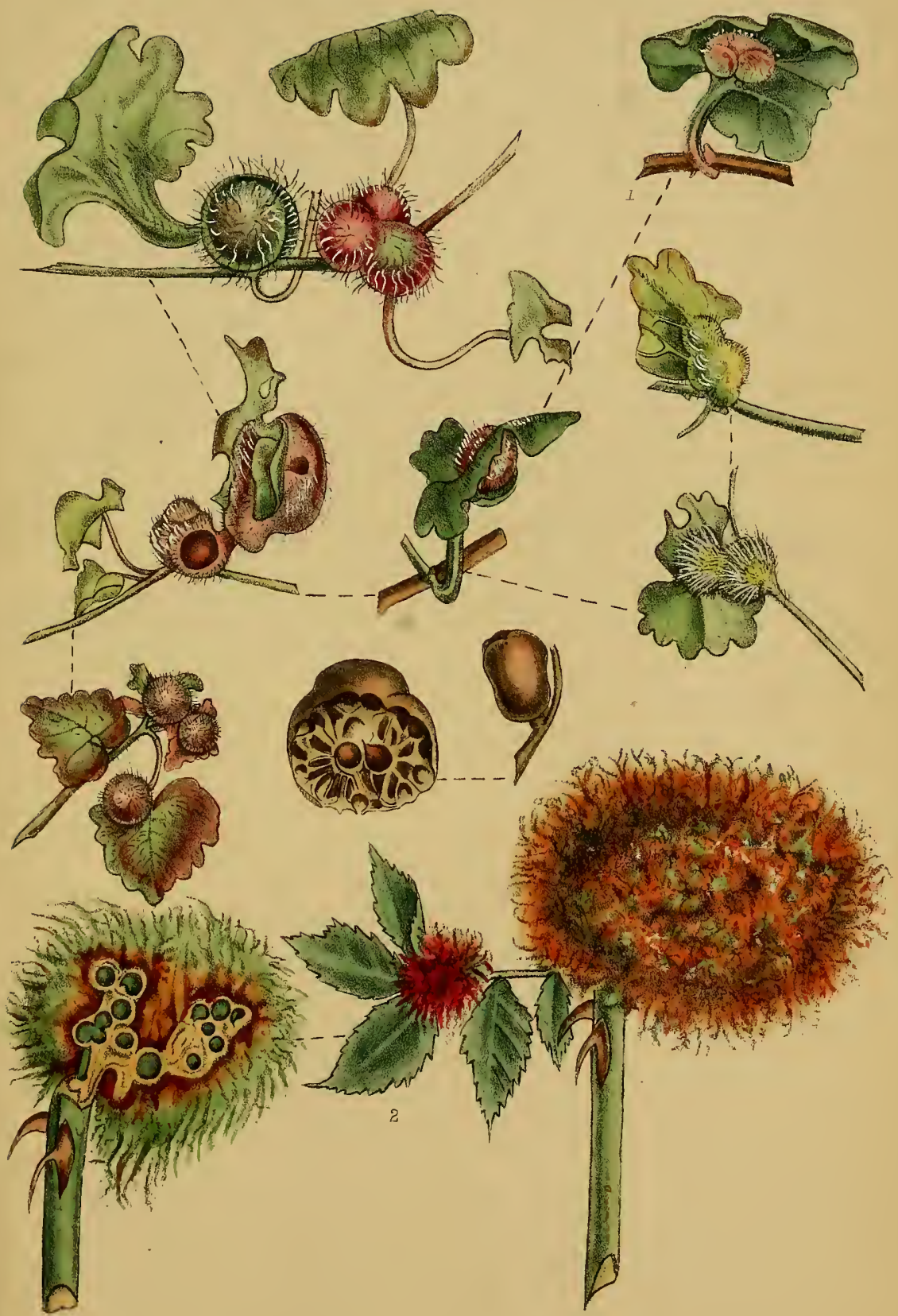

Phyto. Hymen. iv. Plate ll.

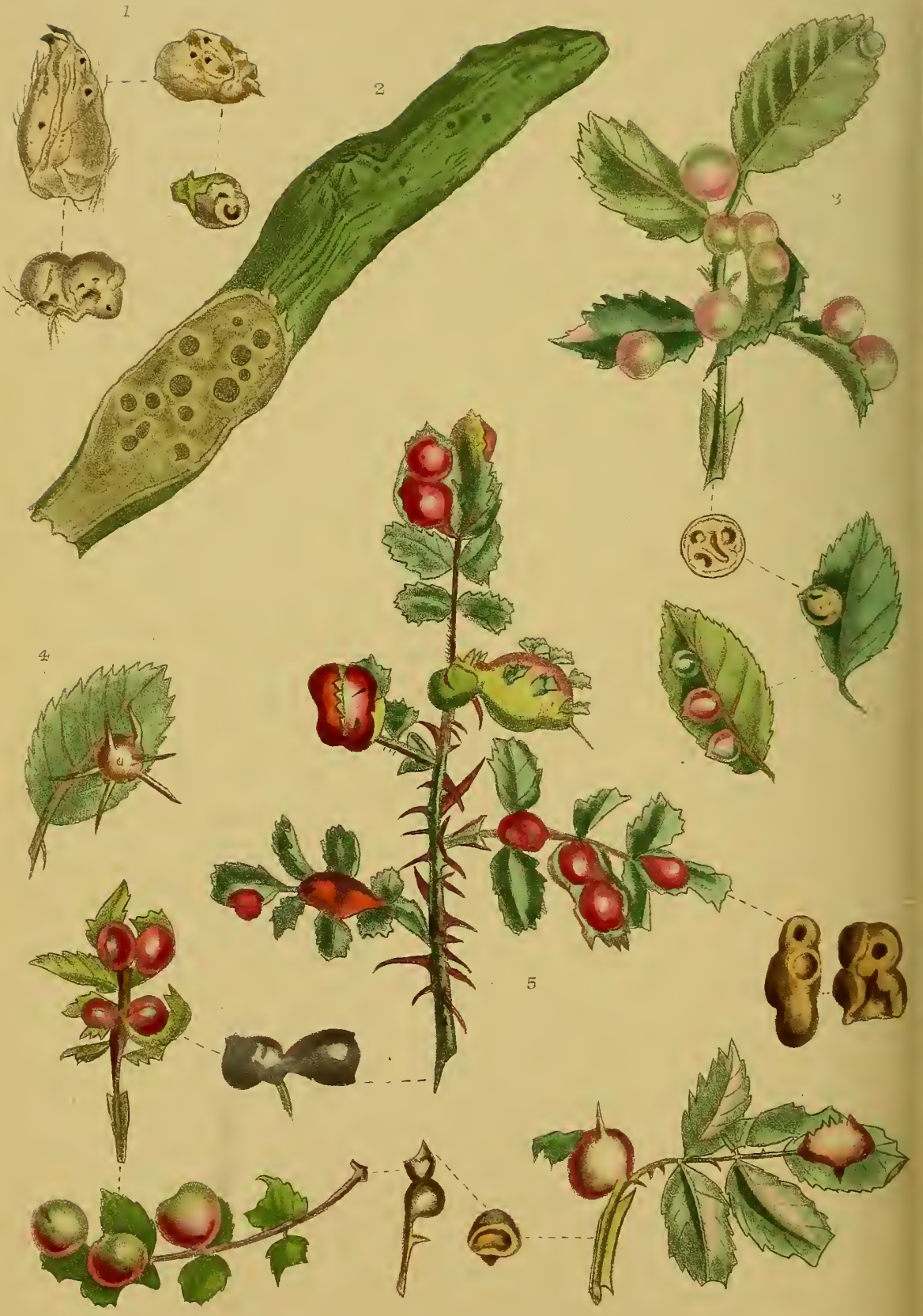

West, Newmarl anm 


\section{PLATE XI.}

Fig. 1.-Galls of Aulax graminis.

Fig. 2.- " Aulax scabiosæ (after Mayr).

Fig. 3.- " Rhodites eglanterix.

Fig. 4.- " $\quad$ Rhodites nervosus.

Fig. 5._ " " Rhodites spinosissimx. 




\section{PLATE XII.}

Fig. 1.-Synergus facialis. $1 a$, abdomen.

Fig. 2.-Synergus apicalis. $2 a$, antennæ.

Fig. 3.-Xenophanes potentillæ. $3 a$, antennæ; $3 b$, tarsus.

Fig. 4.-Synergus nervosus.

Fig. 5.-Synergus melanopus.

Fig. 6.-Synergus Tschelei.

Fig. 7.-Rhodites spinosissimæ.

Fig. 8.-Rhodites eglanterix.

Fig. 9.-Rhodites nervosus.

Fig. 10.-Rhodites rosæ.

Fig. 11.-Aulax hieracii (graminis).

Fig. 12.-Xestophanes brevitarsis, antenna; $12 a$, tarsus. 
Phyto Hymen iv. Platel2.

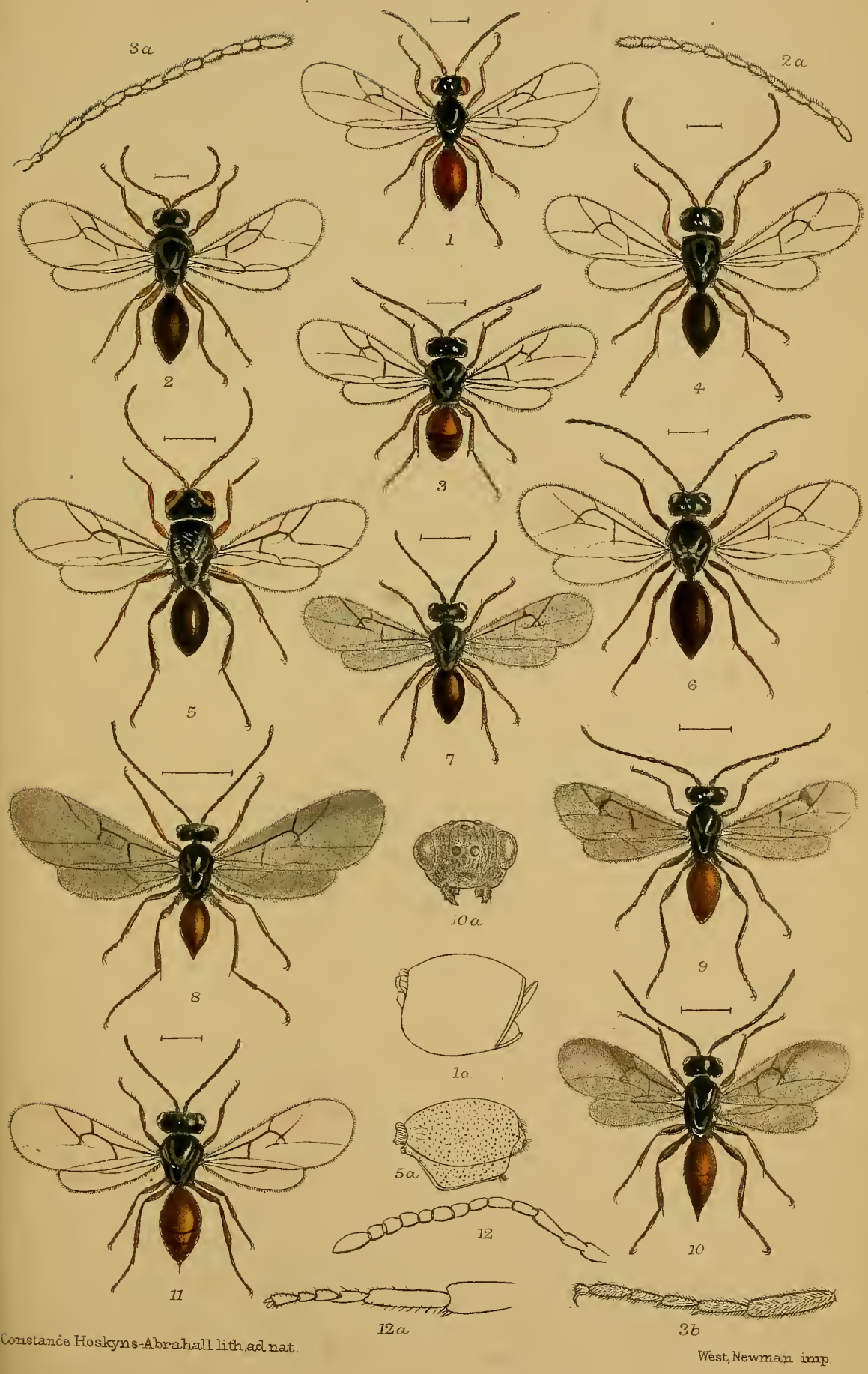






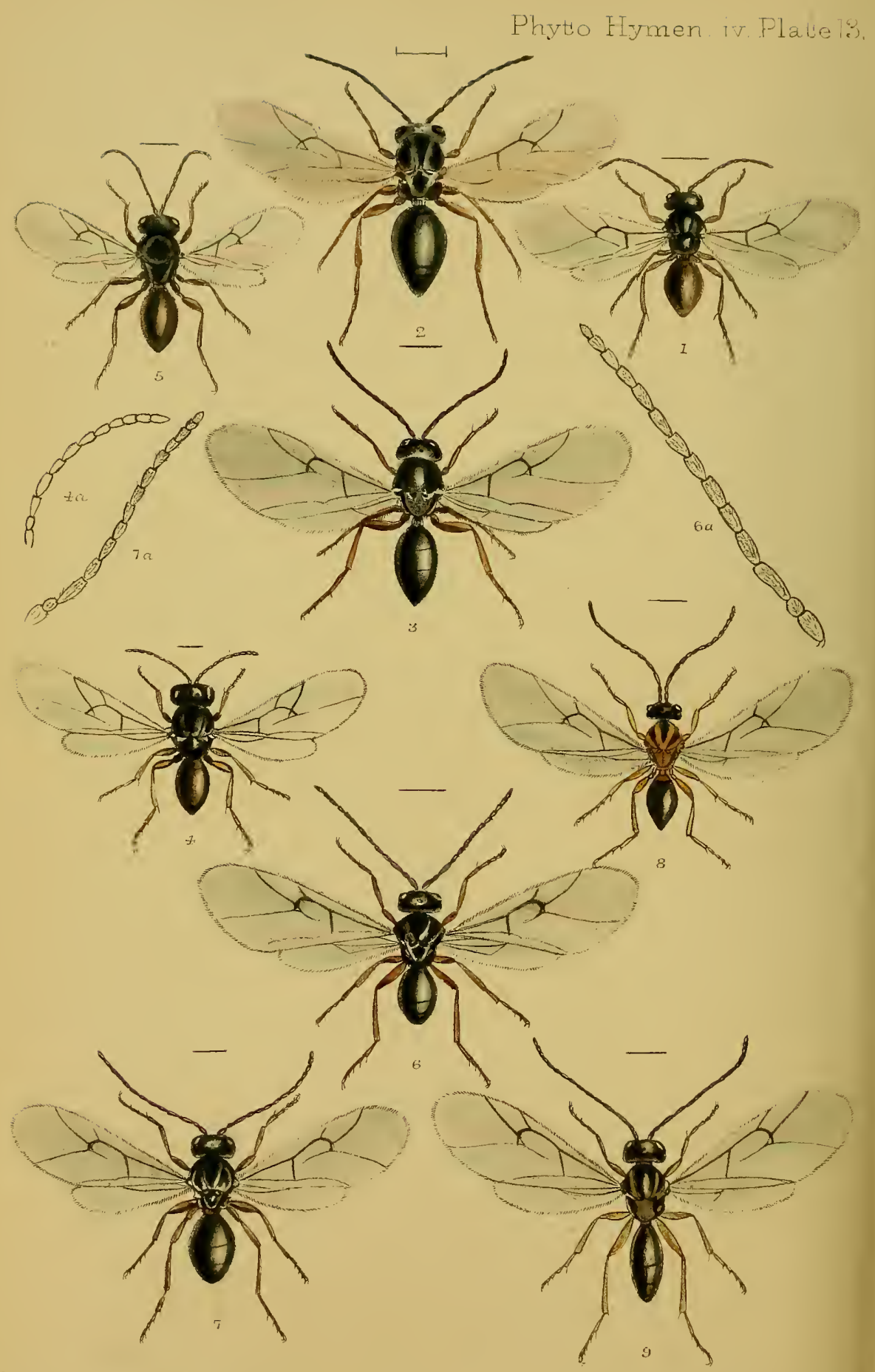




\section{PLATE XIII.}

Fig. 1.-Aulax glechomæ.

Fig. 2.-Periclistus Brandtii.

Fig. 3.-Periclistus caninæ.

Fig. 4.-Ceroptres arator. $4 a$, antenna.

Fig. 5.-Saphylotus connatus.

Fig. 6.-Diastrophus rubi. $6 a$, antenna.

Fig. 7.-Diastrophus aphidivorus. 7 a, antenna.

Fig. 8.-Andricus amenti.

Fig. 9.-Andricus ostreus. 




\section{PLATE XIV.}

Fig. 1.-Andricus fecundatrix.

Fig. 1 a.-Andricus pilosus.

Fig. 2.-Andricus radicis.

Fig. 2 a.-Andricus trilineatus.

Fig. 3.-Andricus Sieboldii.

Fig. 3 a.-Andricus testaceipes.

Fig. 4.-Andricus curvator.

Fig. 4 a.-Andricus collaris.

Fig. 4b.-Andricus collaris. 
Phyto Hymen iv Plate 14

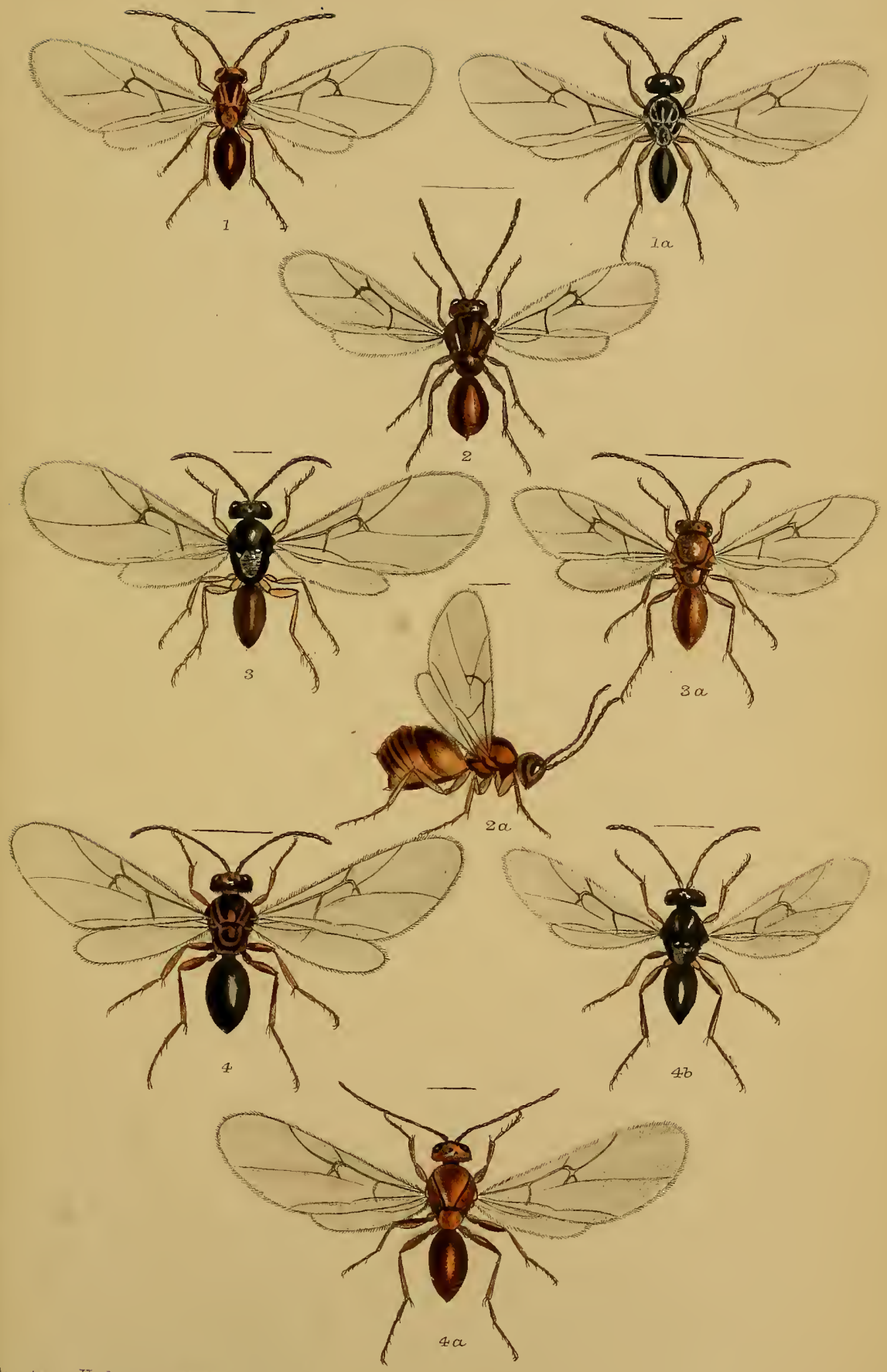






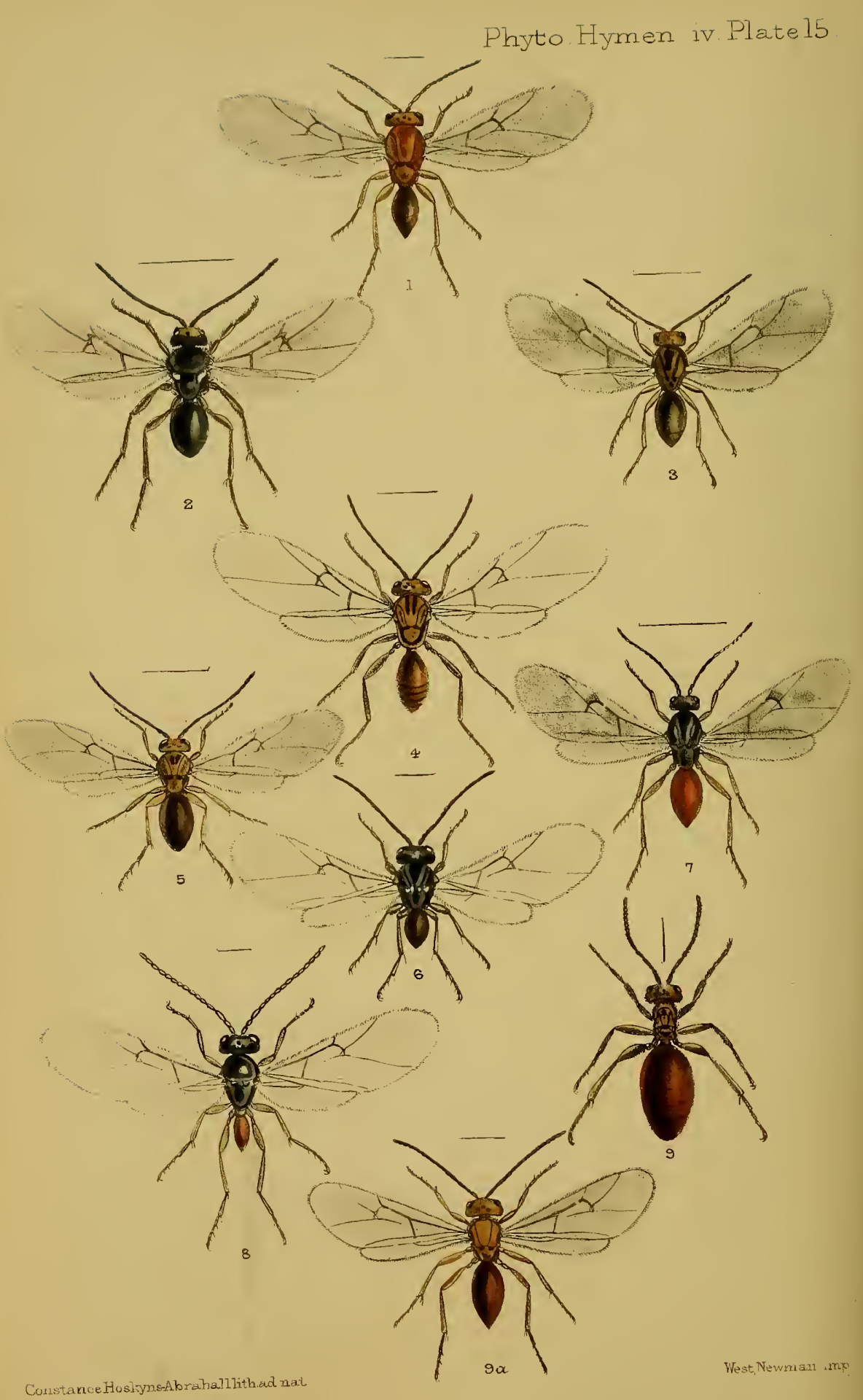




\section{PLATE XV.}

Fig. 1.-Andricus ramuli.

Fig. 2.-Andricus Clementinæ.

Fig. 3.-Andricus solitarius.

Fig. 4.-Andricus quadrilineatus.

Fig. 5.-Andricus glandulæ.

Fig. 6.-Andricus circulans.

Fig. 7.-Trigonaspis megaptera.

Fig. 8.-Andricus cirratus.

Fig. 9.-Biorhiza aptera.

Fig. 9 a.-Biorhiza terminalis. 




\section{PLATE XVI.}

Fig. 1.-Dryophanta divisa.

Fig. 1 a.-Dryophanta verrucosa.

Fig. 2.-Dryophanta folii.

Fig. 3.-Neuroterus numismatis.

Fig. 3 a.-Neuroterus vesicatrix.

Fig. 4.-Neuroterus lenticularis.

Fig. 4 a.-Neuroterus baccarum.

Fig. 5.-Neuroterus fumipennis.

Fig. 6.-Cynips Kollari.

Fig. 7.-Neuroterus punctatus. 
Phyto. Hymen iv. Plate 16.

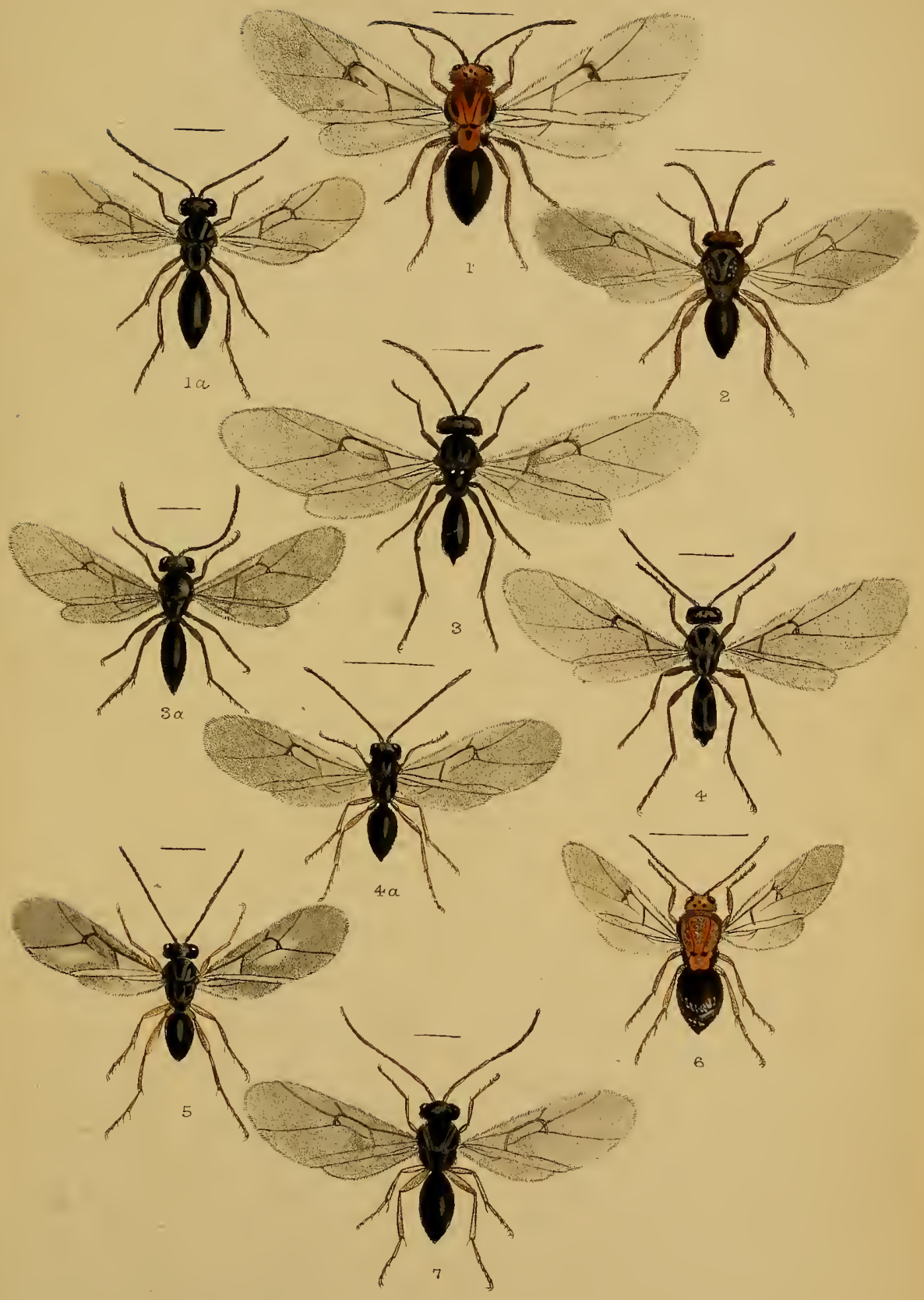

Constance Hoskyns-Alorahall I th ad nat. 


Phyto Hymen iv PlateXVII
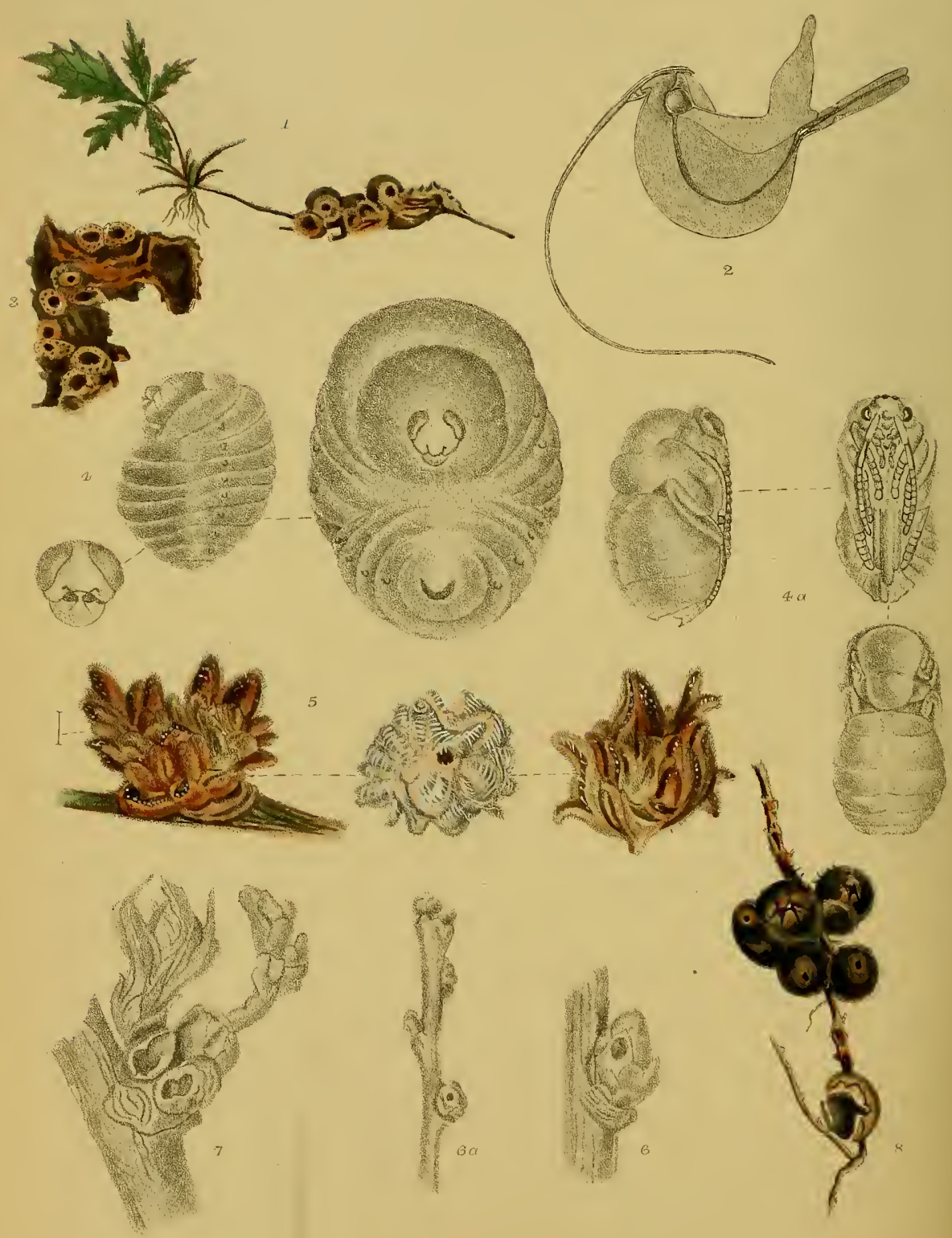


\section{PLATE XVII.}

Fig. 1.-Xestophanes potentillæ, gall.

Fig. 2.-Andricus albopunctata, ovipositor.

Fig. 3.-Andricus corticis, gall.

Fig. 4.-Cynips Kollari, larva, 3 figures ; 4 a, pupa, 3 figures.

Fig. 5.-Cynips gemmæ, gall.

Figs. 6, 6 a.-Gall of Andricus sp. (after Ormerod), see p. 108, where fig. 8 is printed in error for fig. 6 .

Fig. 7.-Gall of Andricus sp. (after Ormerod), see p. 108, where fig. 9 is printed in error for fig. 7 .

Fig. 8.-Biorhiza aptera, gall. 




\section{PLATE XVIII.}

Fig. 1.-Transverse section of gall of Rhodites spinosissimæ.

Fig. 2.-Longitudinal section of gall of Aulax hieracii. $2 a$, transverse section.

Fig. 3.-Transverse section of gall of Andricus albopunctata. $3 a$, longitudinal section. 
Phyto Hymen. Iv. Plate XVIII

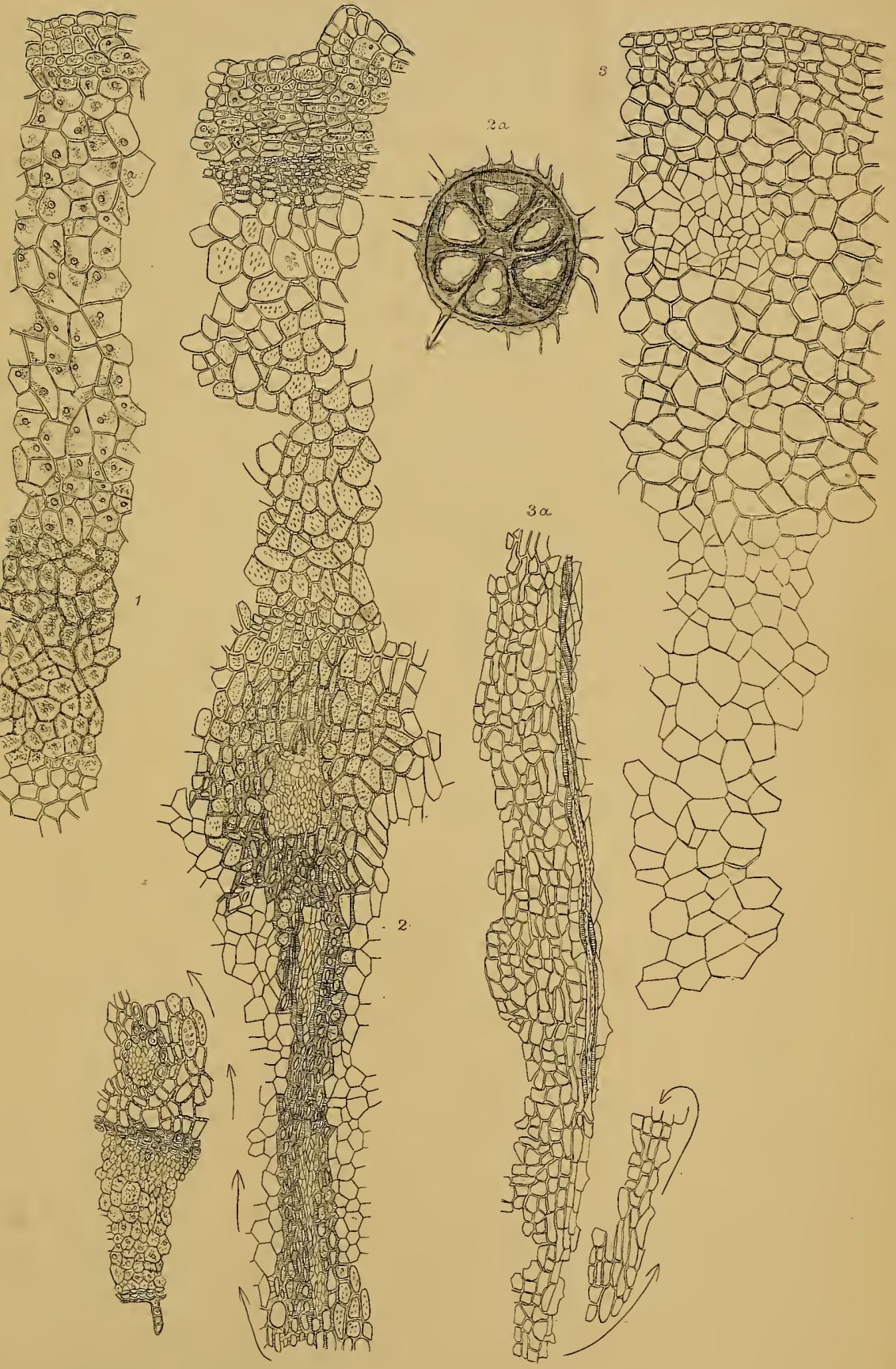

Constance Hoskyns-Alorahall sc ad.nat. 

Phyto Hymen. IV Plate XIX
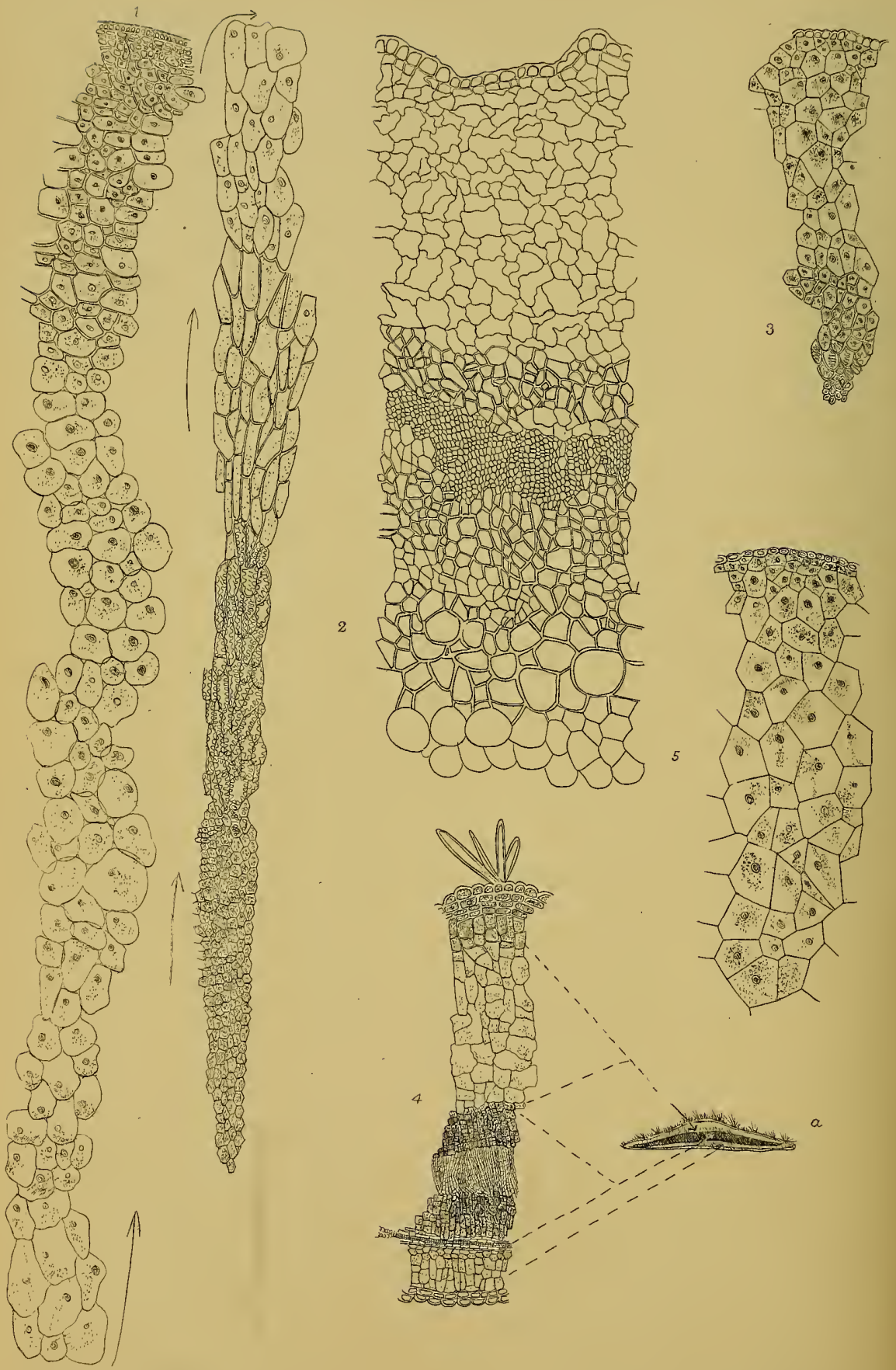

ODO

-108710 or 5 ,

7ol

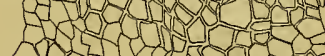

2
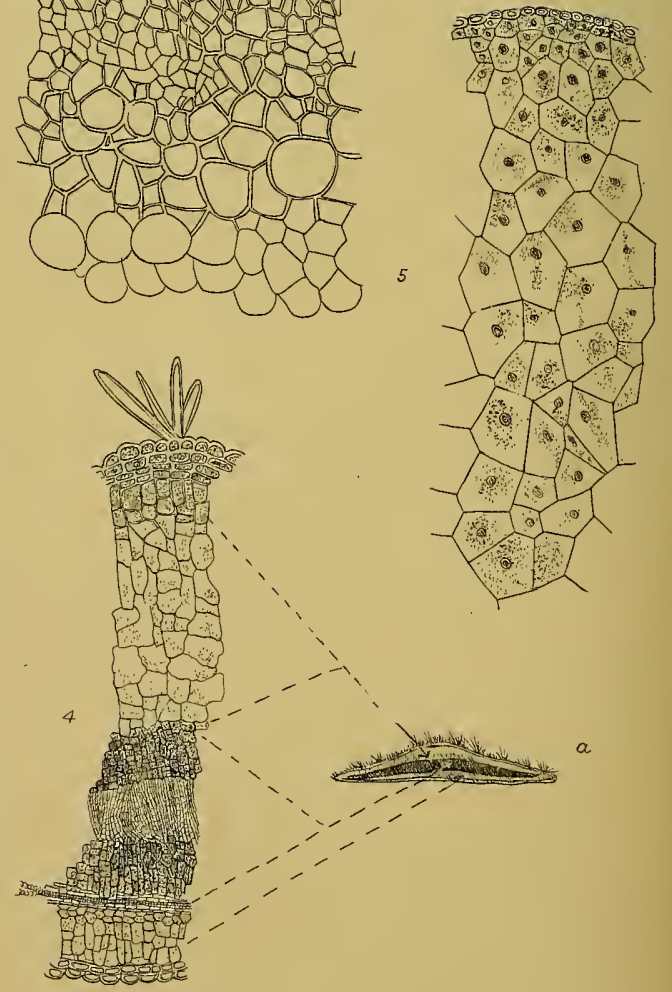


\section{PLATE XIX.}

Fig. 1.-Transverse section of gall of Cynips Kollari.

Fig. 2.-Transverse section of gall of Andricus curvator.

Fig. 3.-Transverse section of gall of Trigonaspis megaptera.

Fig. 4.-Longitudinal section of gall of Neuroterus lenticularis; 4 a. transverse section of gall of Neuroterus lenticularis.

Fig. 5.-Transverse section of gall of Neuroterus baccarum. 




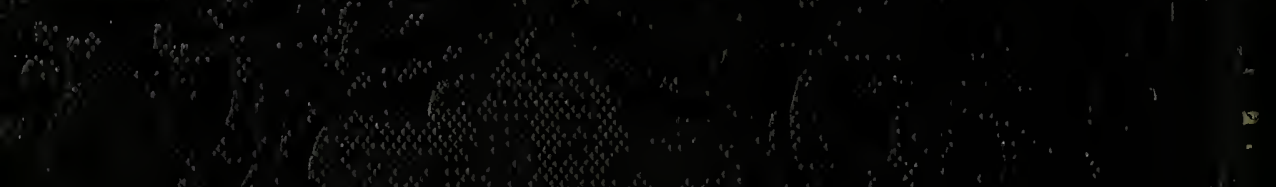

M.c

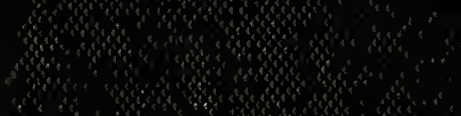

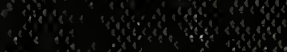

"

1\%

W

(1)

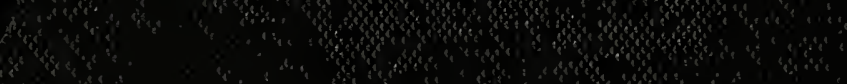

4

4.

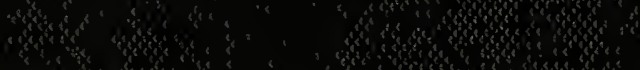

4.

a

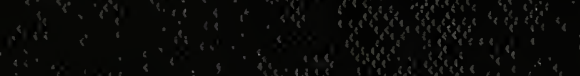

a

(1)

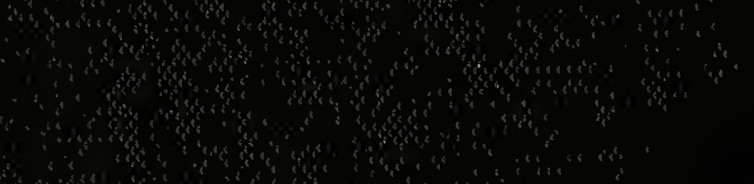

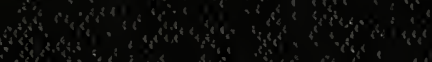

48 ond

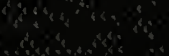

(1)

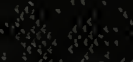

8

.

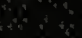

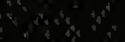

…

is 